\title{
Pesquisa de mutações do gene GRN e dosagem plasmática de progranulina em casuística brasileira de degeneração lobar frontotemporal
}

\author{
Tese apresentada à Faculdade de \\ Medicina da Universidade de São Paulo \\ para obtenção do título de Doutor em \\ Ciências \\ Programa de Neurologia \\ Orientador: Prof. Dr. Ricardo Nitrini
}


Dados Internacionais de Catalogação na Publicação (CIP)

Preparada pela Biblioteca da

Faculdade de Medicina da Universidade de São Paulo

Creprodução autorizada pelo autor

Takada, Leonel Tadao

Pesquisa de mutações do gene GRN e dosagem plasmática de progranulina em casuística brasileira de degeneração lobar frontotemporal / Leonel Tadao Takada. -São Paulo, 2015

Tese(doutorado)--Faculdade de Medicina da Universidade de São Paulo.

Programa de Neurologia.

Orientador: Ricardo Nitrini.

Descritores: 1.Degeneração lobar frontotemporal 2.Demência frontotemporal 3.Afasia primária progressiva não fluente 4.Genética 5.Tauopatias 6.Proteinopatias TDP-43 7.Mutação

USP/FM/DBD-127/15 


\section{DEDICATÓRIA}

\section{Para Roberta}

Para Thomas, Carol, Theo, Michelle e Matteo 


\section{AGRADECIMENTOS}

A Deus, aos meus pais e aos meus irmãos e cunhados;

Ao Prof. Dr. Ricardo Nitrini por ter sido figura fundamental na minha carreira desde o terceiro ano da faculdade de medicina. Obrigado pelo apoio que recebi sempre que precisei, e pelo constante encorajamento;

À Roberta Diehl Rodriguez pelo amor, companheirismo e apoio incondicional, mesmo nos momentos mais difíceis desta caminhada;

Ao Dr. Bruce L. Miller pelos ensinamentos durante meu estágio na Universidade da Califórnia, em São Francisco, e por todas as oportunidades que me deu e tem dado desde então;

À Dra. Valéria Santoro Bahia pela amizade e por todo o apoio durante a realização deste estudo;

À Dra. Jennifer S. Yokoyama por ter me ensinado tanto sobre genética, e com isso, ter contribuído para que eu me interessasse cada vez mais pelo assunto;

À Prof. Dra. Sonia Maria Dozzi Brucki e à Ma. Maira Okada de Oliveira pela amizade, paciência e pelos conselhos;

Ao Prof. Dr. Gerson Chadi por todo apoio que deu durante a execução deste projeto;

À Dra. Jéssica Ruivo Maximino por toda ajuda (principalmente nos últimos meses!);

Aos meus amigos da CNNA: Dra. Marcia Rubia Rodrigues Gonçalves, Dra. Jerusa Smid, Dra. Cláudia Sellitto Porto, Dra. Mirna Lie Hosogi Senaha e Dr. Fabio Henrique Gobbi Porto. Especialmente Jerusa e Marcia por facilitarem ao máximo minha vida nos últimos meses; 
A todos os membros do Memory and Aging Center da Universidade da Califórnia em São Francisco, com quem aprendi tanto e que me fizeram sentir tão confortável durante o estágio. Em especial a Michael D. Geschwind, MD, PhD, Sharon J. Sha, MD, MSc, Zachary A. Miller, MD, Caroline Latham, e Leslie Goss;

Aos meus amigos e colegas do Grupo de Neurologia Cognitiva e do Comportamento do Hospital das Clínicas da Faculdade de Medicina de São Paulo. E em especial às voluntárias Mary e Cida;

À Elisângela Quedas e ao Lucas Santana, do LIM-25, por se esforçarem para me ajudar com os prazos, sempre com muita simpatia;

À Ma. Thais Costa pela ajuda nas fases iniciais deste projeto, principalmente pela paciência para me ensinar os métodos laboratoriais;

Aos funcionários e alunos do LIM-45, em especial Sarah, Florence, e Samantha Nakamura;

Ao Prof. Dr. Paulo Caramelli pelo apoio que tem me dado ao longo dos anos, mesmo à distância, e por toda disposição que demonstrou em ajudar. Também ao Dr. Henrique Cerqueira, Dra. Sarah Camargos e demais membros do grupo de Neurologia Cognitiva e do Comportamento da UFMG, pela disposição em garantir que a colaboração desse certo;

À Prof. Dra. Lea T. Grinberg e à Dra. Camila F. do Nascimento do GEROLAB, pelo auxílio na obtenção dos dados neuropatológicos que complementam os achados deste projeto;

À Fundação de Amparo à Pesquisa do Estado de São Paulo (FAPESP), e à Federico Foundation - Wilhelm Agrícola Research Grants, pelo apoio financeiro para a realização desta pesquisa; 
E principalmente aos pacientes, familiares de pacientes e voluntários que se dispuseram a participar deste estudo. Nada disto seria possível sem vocês, e espero um dia poder retribuir a ajuda. 


\section{RESUMO}

Takada LT. Pesquisa de mutações do genes GRN e dosagem plasmática de progranulina em casuística brasileira de degeneração lobar frontotemporal [tese]. São Paulo: Universidade de São Paulo, Faculdade de Medicina, 2015.

Introdução: A demência frontotemporal (DFT) inclui a variante comportamental da demência frontotemporal (vcDFT), a variante semântica da afasia progressiva primária (vsAPP), e a variante não fluente da APP (vnfAPP). Os genes em que são encontradas mutações causadoras de DFT mais frequentemente são: GRN (que codifica a progranulina), MAPT (que codifica a proteína tau) e C9orf72. Métodos: Foram incluídos probandos diagnosticados com vcDFT, vsAPP ou vnfAPP, com base com os critérios diagnósticos mais recentes, e um grupo de indivíduos cognitivamente normais. Os éxons 2-12 de GRN e os éxons 1, 9-13 de MAPT foram sequenciados pelo método de Sanger, e foi realizada dosagem de progranulina no plasma. Resultados: foram incluídos 62 probandos, sendo 44 com vcDFT, 9 com vsAPP, e 9 com vnfAPP. Antecedente familiar de demência foi positivo em 45,1\% dos probandos, e de DFT, em 24,1\%. Os 60 indivíduos do grupo controle tinham idade média de $60,8 \pm 8,5$ anos. Foram identificadas seis mutações nulas em GRN (p.Q130X, p.V200Gfs*18, p.Q257Pfs ${ }^{\star 26}$, p.Q300X, p.S301Cfs*60 e p.D317Afs*11) e uma mutação patogênica em MAPT (p.N279K). A dosagem média de progranulina plasmática nos pacientes com mutações de $G R N$ foi de $29,8 \pm 11,9 n g / m l$ Conclusões: A frequência de mutações patogênicas em GRN nesta casuística foi de 9,6\%, e a de mutações em MAPT foi de 1,6\%. Entre casos familiais de DFT, a frequência de mutações em GRN foi de 33,3\%, e em MAPT foi de 6,7\%. Duas das mutações encontradas em GRN (p.Q130X e p.D317Afs*11) ainda não foram descritas em casos de DFT. O valor de corte de $70 \mathrm{ng} / \mathrm{ml}$ identificou as mutações nulas de GRN com sensibilidade e especificidade de $100 \%$.

Descritores: degeneração lobar frontotemporal; demência frontotemporal; afasia primária progressiva não fluente; genética; tauopatias; proteinopatias TDP-43; mutação. 


\begin{abstract}
Takada LT. Mutations in GRN and plasma progranulin levels in a Brazilian cohort of Frontotemporal Lobar Degeneration [thesis]. São Paulo: "Faculdade de Medicina, Universidade de São Paulo", 2015.

Introduction: Frontotemporal dementia (FTD) encompasses behavioral variant of frontotemporal dementia (bvFTD), semantic variant of primary progressive aphasia (svPPA), and nonfluent variant PPA (nfvPPA). The genes in which FTD-causing mutations are most frequently found are: GRN (which encodes progranulin), MAPT (which encodes tau protein) and C9orf72. Methods: We included probands diagnosed with bvFTD, svPPA or nfvPPA, based on the most recent diagnostic criteria, and a group of cognitively normal individuals. GRN exons 2-12 and MAPT exons 1, 9-13 were sequenced by the Sanger method, and plasma progranulin levels were measured. Results: we included 62 probands (44 with bvFTD, 9 with svPPA, and 9 with nfvPPA). Family history of dementia was positive in $45.1 \%$ of probands, and of DFT, in $24.1 \%$. The control group of 60 individuals had a mean age of $60.8 \pm 8.5$ years. Six null GRN mutations were identified in (p.Q130X, p.V200Gfs*18, p.Q257Pfs*26, p.Q300X, p.S301Cfs*60 e p.D317Afs*11) and one MAPT pathogenic mutation (p.N279K). The mean plasma progranulin level in patients with GRN mutations was $29.8 \pm 11,9 \mathrm{ng} / \mathrm{ml}$. Conclusions: The frequency of pathogenic mutations in GRN was $9.6 \%$, and of MAPT mutations was $1.6 \%$. Among cases of familial FTD, the frequency of GRN mutations was $33.3 \%$, and of MAPT mutations was $6.7 \%$. Two of the mutations found in GRN (p.Q130X and p.D317Afs*11) are novel. The cutoff value of $70 \mathrm{ng} / \mathrm{ml}$ identified null GRN mutations with sensitivity and specificity of $100 \%$.
\end{abstract}

Descriptors: frontotemporal lobar degeneration; frontotemporal dementia; primary progressive nonfluent aphasia; tauopathies; TDP-43 proteinopathies; mutation. 


\section{LISTA DE FIGURAS}

Figura 1 - Mutações em MAPT. Página 12

Figura 2 - Mutações em GRN. Página 17

Figura 3 - Estrutura do gene C9orf72 e localização da expansão

(GGGGCC) Página 20

Figura 4 - Mutação GRN p.Q257Pfs²6. .Página 51

Figura 5 - Neuroimagem do probando DFT 11 Página 53

Figura 6 - Heredograma da família do probando DFT 11 Página 54

Figura 7 - Mutação GRN p.Q300X Página 55

Figura 8 - Neuroimagem do probando DFT 22 Página 56

Figura 9 - Heredograma da família do probando DFT 22 Página 57

Figura 10 - Mutação GRN p.V200Gfs*18 .Página 58

Figura 11 - Neuroimagem do probando DFT 53. .Página 60

Figura 12 - Heredograma da família do probando DFT 53 Página 62

Figura 13 - Mutação GRN p.Q130X. Página 63

Figura 14 - Heredograma da família do probando DFT 58 Página 64

Figura 15 - Neuroimagem do probando DFT 58 Página 65

Figura 16 - Neuroimagem da irmã do probando DFT 58 Página 67

Figura 17 - Mutação GRN p.D317Afs*11 .Página 68

Figura 18 - Neuroimagem do probando DFT 63 Página 69

Figura 19 - Estudo neuropatológico do probando DFT 63 Página 70

Figura 20 - Heredograma da família do probando DFT 63 Página 71

Figura 21 - Neuroimagem da mãe do probando DFT 63 Página 72

Figura 22 - Mutação GRN p.S301Cfs* 60 Página 73

Figura 23 - Neuroimagem do probando DFT 64 Página 76

Figura 24 - Heredograma da família do probando DFT 64. Página 77

Figura 25 - Mutação MAPT p.N279K. Página 78

Figura 26 - Neuroimagem do probando DFT 17 .Página 80

Figura 27 - Heredograma da família do probando DFT 17 Página 81

Figura 28 - Dosagem plasmática de progranulina. .Página 83 


\section{LISTA DE TABELAS}

Tabela 1 - Critérios diagnósticos da vcDFT. Página 03 Tabela 2 - Critérios de Inclusão e Exclusão para o diagnóstico de Afasia Progressiva Primárias Página 05

Tabela 3 - Critérios diagnósticos da variante semântica da Afasia Progressiva Primária Página 06

Tabela 4 - Critérios diagnósticos da variante não fluente da Afasia Progressiva Primária .Página 07

Tabela 5 - Subtipos da DLFT-TDP e correlações com clínica e genética ....Página 09 Tabela 6 - Sequências iniciadoras (primers) utilizadas para amplificação dos éxons 2 a 13 de $G R N$ Página 46

Tabela 7 - Sequências iniciadoras (primers) utilizadas para amplificação dos éxons 1,9 a 13 de $M A P T$. Página 47

Tabela 8 - Dados demográficos e clínicos da casuística de DFT Página 50

Tabela 9 - Médias e desvios-padrão da dosagem plasmática de progranulina Página 82

Tabela 10 - Polimorfismos não patogênicos encontrados em GRN. Página 84

Tabela 11 - Polimorfismos não patogênicos encontrados em MAPT. Página 84 Tabela 12 - Frequência de mutações patogênicas de GRN e de MAPT em diversas casuísticas Página 86

Tabela 13 - Valores da dosagem de progranulina plasmática em estudos prévios.

Página 94 


\section{LISTA DE ABREVIATURAS}

APP: afasia progressiva primária

BBRC: bateria breve de rastreio cognitivo

CEREDIC: centro de referência em distúrbios cognitivos

DA: doença de Alzheimer

DCB: degeneração corticobasal

DFT: demência frontotemporal

DLFT: degeneração lobar frontotemporal

DNA: ácido deoxirribonucleico

DNM: doença do neurônio motor

ELA: esclerose lateral amiotrófica

ELISA: enzyme-linked immunosorbent assay

ESE: exonic splicing enhancer

FDG-PET: Fluorodeoxyglucose positron emission tomography (tomografia por emissão de pósitrons com fluordeoxiglicose)

GNCC: grupo de neurologia cognitiva e do comportamento

GWAS: genome-wide association study (estudo de associação genômica ampla)

HCFMUSP: Hospital das Clínicas da Faculdade de Medicina da Universidade de São Paulo

LCR: líquido cefalorraquidiano

MEEM: mini-exame do estado mental

OR: odds ratio (razão de chances)

PSP: paralisia supranuclear progressiva

QAF: questionário de atividades funcionais

RNA: ácido ribonucléico

SCB: síndrome corticobasal

SNP: single nucleotide polymorphism (polimorfismo de nucleotídeo único)

SPECT: single photon emission computed tomography (tomografia computadorizada por emissão de fóton único)

vcDFT: variante comportamental da demência frontotemporal vnfAPP: variante não fluente da afasia progressiva primária vsAPP: variante semântica da afasia progressiva primária 


\section{SUMÁRIO}

1. INTRODUÇÃO. Página 01

1.1. Demência Frontotemporal - aspectos clínicos Página 01

1.1.1. Variante Comportamental da Demência Frontotemporal. Página 02

1.1.2. Variante semântica da Afasia Progressiva Primária Página 04

1.1.3. Variante não fluente da Afasia Progressiva Primária Página 06 1.2. Neuropatologia da DLFT Página 07

1.3. Genética da DLFT Página 09

1.3.1. Genes associados às formas monogênicas da DLFT Página 11

1.3.1.1. Gene MAPT. Página 11

1.3.1.2. Gene GRN. Página 15

1.3.1.3. Genes associados ao espectro das DLFT-DNM Página 20

1.3.1.3.1. Gene C9orf72. .Página 20

1.3.1.3.2. Gene TARDBP. Página 26

1.3.1.3.3. Gene FUS. .Página 28

1.3.1.3.4. Gene UBQLN2. Página 29

1.3.1.3.5. Outros genes do espectro das DLFT-DNM Página 30

1.3.1.4. Genes associados às Proteinopatias Multissistêmicas...Página 31 1.3.1.4.1. Gene VCP. .Página 32

1.3.1.4.2. Genes HNRNPA2B1 e HNRNPA1 .Página 33

1.3.1.4.3. Gene SQSTM1 .Página 34

1.3.1.5. Gene CHMP2B. .Página 35

1.3.2. Genes associados às formas poligênicas da DLFT. .Página 36 1.4. Biomarcadores no sangue e líquido cefalorraquidiano na DLFT Página 38 1.4.1. Tau .Página 38

1.4.2. TDP-43 Página 39

1.4.3. Progranulina .Página 39

1.4.4. Proteínas com repetições de dipeptídeos Página 41

1.4.5. Neurofilamentos de cadeia leve Página 41

2. OBJETIVOS Página 43

3. CASUÍSTICA E MÉTODOS. Página 44 3.1. Casuística. 
3.2. Metodologia laboratorial. .Página 45

3.2.1. Sequenciamento Página 45

3.2.2. Determinação dos níveis plasmáticos de progranulina. .Página 48

4. RESULTADOS. .Página 50

4.1. Casuística. Página 50

4.2. Mutações patogênicas encontradas em GRN Página 51

4.2.1. Probando DFT 11: GRN p.Q257Pfs*26 .Página 51

4.2.2. Probando DFT 22: GRN p.Q300X .Página 54

4.2.3. Probando DFT 53: GRN p.V200Gfs ${ }^{*} 18$ .Página 58

4.2.4. Probando DFT 58: GRN p.Q130X .Página 62

4.2.5. Probando DFT 63: GRN p.D317Afs ${ }^{*} 11$ Página 67

4.2.6. Probando DFT 64: GRN p.S301Cfs* 60 Página 73

4.3. Mutações patogênicas encontradas em MAPT. Página 77

4.3.1. Probando DFT 17: MAPT p.N279K Página 77

4.4. Dosagem plasmática de progranulina .Página 81

4.5. Polimorfismos não patogênicos encontrados na casuística Página 83

5. DISCUSSÃO. .Página 85

6. CONCLUSÕES. Página 103 REFERÊNCIAS BIBLIOGRÁFICAS Página 104 ANEXOS

Anexo I - Aprovação do protocolo de pesquisa CAPPesq 0252/10

Anexo II - Termo de Consentimento Livre e Esclarecido

Anexo III - Aprovação do Projeto FAPESP (2013/01758-4) 


\section{INTRODUÇÃO}

\subsection{Demência Frontotemporal - aspectos clínicos}

O termo Demência Frontotemporal (DFT) se refere a um grupo de doenças caracterizadas por degeneração focal dos lobos temporais e/ou frontais do cérebro. ${ }^{1}$ Clinicamente, a DFT é subclassificada em uma variante comportamental (variante comportamental da DFT, vcDFT) e em duas variantes de linguagem, denominadas variante não fluente ou agramática da Afasia Progressiva Primária (vnfAPP) e variante semântica da APP (vsAPP). ${ }^{1-3}$

A primeira descrição de vcDFT é atribuída a Arnold Pick, que em 1904 publicou um relato de caso de uma paciente de 41 anos que desenvolveu um quadro demencial, em que predominavam manifestações comportamentais como estereotipias, embotamento do afeto e perda de motivação (citado por Spatt, 2003). ${ }^{4}$

O termo APP foi criado por M-Marsel Mesulam, após uma publicação seminal de 1982 em que descreveu uma série de casos de afasia lentamente progressiva sem demência. ${ }^{5,6}$ Mas a descrição do primeiro caso de APP também é atribuída a Pick, que em 1892 relatou um paciente com afasia e atrofia focal do hemisfério esquerdo, particularmente do lobo temporal (citado por Spatt, 2003). ${ }^{4}$

Outros pesquisadores e grupos de pesquisa foram caracterizando ao longo das décadas de 1970 a 1990, formas de afasias neurodegenerativas, que hoje conhecemos como variantes da APP. ${ }^{2} \mathrm{O}$ termo demência semântica foi proposto por Julie Snowden e colegas em 1989 para caracterizar casos de atrofia circunscrita dos lobos temporais associados a perda seletiva de memória semântica. ${ }^{7}$ Nos anos 1990 , outra forma de afasia neurodegenerativa foi sendo descrita, caracterizada por comprometimento dos aspectos motores da fala, e nomeada de afasia progressiva não fluente. ${ }^{2,8} \mathrm{Em} 2011$ foram publicados os critérios diagnósticos de consenso das APPs, que sugeriu os termos vsAPP e vnfAPP ao invés de demência semântica e afasia progressiva não fluente, respectivamente, com intuito de uniformizar as publicações científicas. $^{2}$

Dentro do grupo das APPs existe ainda uma terceira variante, conhecida como variante logopênica da APP (vIAPP) ou afasia progressiva logopênica, que foi descrita 
em 2004 pelo grupo de Maria Luiza Gorno-Tempini, na Universidade da Califórnia em São Francisco, EUA. ${ }^{9}$ A vIAPP geralmente não é incluída dentro do grupo das DFTs pois o diagnóstico neuropatológico mais frequente na vIAPP é de doença de Alzheimer (DA), e por isso ela é classificada como uma variante da DA. ${ }^{2}$

A DFT é considerada a segunda causa mais frequente de demência em pacientes com idade de início inferior a 65 anos (em algumas casuísticas apresentando prevalência similar à da DA nessa faixa etária). ${ }^{10-14}$ Estima-se que a prevalência de DFT seja de $15-22$ casos por 100.000 habitantes, e a incidência de 2,7-4 casos por 100.000 habitantes/ano. ${ }^{15} \mathrm{~A}$ idade de início dos sintomas é variável, em geral entre 45 e 65 anos, mas pode variar entre a terceira e nona décadas de vida; e na maior parte dos estudos a prevalência é similar entre homens e mulheres. ${ }^{16,17} \mathrm{~A}$ sobrevida dos pacientes após início dos sintomas é de aproximadamente 6 a 9 anos, mas a presença de doença do neurônio motor (DNM) reduz significativamente a sobrevida. ${ }^{15,18,19}$

\subsubsection{Variante Comportamental da Demência Frontotemporal}

É a variante mais frequente da DFT. Em estudo colaborativo de 3 centros - nos Estados Unidos da América e na Alemanha - com 353 pacientes, vcDFT foi diagnosticada em $56,7 \%$ dos pacientes (seguida por vnfAPP em $24,6 \%$ e vsAPP em $18,6 \%)^{20}$

A vcDFT é caracterizada por quadro comportamental insidioso e progressivo, com mudanças na personalidade e no comportamento social. Além das mudanças comportamentais observa-se declínio cognitivo, particularmente no funcionamento executivo. E eventualmente ao quadro clínico podem se associar distúrbio de linguagem, sintomas extrapiramidais e/ou DNM. ${ }^{16,21}$

As mudanças comportamentais podem incluir apatia (sugerindo disfunção de estruturas pré-frontais dorsomediais) e/ou desinibição (associada a disfunção préfrontal orbitofrontal e ventromedial), além de embotamento afetivo, perda de crítica (insight), perda de modos e decoro social, comportamentos estereotipados e perseverativos, e/ou mudanças no comportamento alimentar. ${ }^{1,16}$ 
As queixas cognitivas podem ser menos proeminentes no início, porém ocorre declínio cognitivo com déficits em tarefas frontais/funções executivas, e preservação relativa de memória episódica e das funções visuoespaciais. ${ }^{16,22,23}$

O início dos sintomas ocorre por volta dos 45-65 anos de idade (podendo variar entre terceira e oitava décadas), e há certa preponderância masculina. ${ }^{20,24}$ Associação entre vcDFT e DNM - particularmente esclerose lateral amiotrófica (ELA) - ocorre em cerca de $15 \%$ dos casos de vcDFT, ${ }^{25}$ e parkinsonismo é observado em $10-20 \%$ dos pacientes. ${ }^{3,26}$

Os critérios diagnósticos de vcDFT mais recentes foram publicados em 2011, e estão detalhados na Tabela $1 .{ }^{3}$ Os critérios admitem diagnóstico de vcDFT possível (baseado em sintomas e sinais) ou provável (quando o paciente apresenta além dos sinais e sintomas típicos, perda funcional e achados de neuroimagem típicos). Para o diagnóstico de vcDFT possível, o paciente deve apresentar três dos tipos de sintomas (A-E) listados na Tabela 1.

Tabela 1 - Critérios diagnósticos da vcDFT

A. Desinibição comportamental precoce;

1. Comportamentos socialmente inapropriados,

2. Perda de modos ou decoro, ou

3. Atos impulsivos, precipitados.

\section{B. Apatia ou inércia precoce;}

1. Perda de empatia ou simpatia/compaixão precoce,

2. Indiferença em relação às necessidades/sentimentos de outros, ou

3. Diminuição no interesse social, em relacionamentos mútuos ou de afeto.

C. Comportamentos compulsivos/ritualísticos, estereotipados, ou perseverativos precoces;

1. Movimentos repetitivos simples,

2. Comportamentos complexos, compulsivos ou ritualísticos, ou

3. Estereotipias da fala.

\section{Hiperoralidade e mudanças na dieta;}

1. Mudanças nas preferências alimentares,

2. Binge eating, aumento no consumo de álcool ou cigarros, ou

3. Exploração oral ou consumo de objetos não comestíveis.

E. Perfil neuropsicológico: disfunção executiva com preservação relativa de memória e habilidades visuoespaciais.

Referência: Rascovsky et al., $2011^{3}$

Para o diagnóstico de vcDFT provável, o paciente deve preencher critérios para vcDFT possível e apresentar declínio funcional, além de neuroimagem mostrando atrofia ou hipoperfusão/hipometabolismo em regiões frontais e/ou temporais 
anteriores. A sensibilidade dos critérios do International Behavioral Variant Frontotemporal Dementia Consortium é de 86-95\% para vcDFT possível e de 76-85\% para vcDFT provável. ${ }^{3,27,28}$ A sensibilidade dos critérios de 2011 é significativamente maior que a dos critérios de Neary et al. publicados em 1998; além disso os novos critérios apresentam boa confiabilidade interexaminador. 1,3,29

Em estudos de neuroimagem funcional (FDG-PET e SPECT), os achados mais frequentemente descritos são de hipometabolismo/hipofluxo frontal, temporal anterior e de cíngulo anterior; e com a evolução da doença pode haver extensão para regiões temporo-parietais. ${ }^{24,30}$ Estudos de neuroimagem estrutural podem ser normais no início da doença; porém com a progressão da doença, observa-se atrofia focal dos lobos frontais e temporais, particularmente das regiões frontais mesiais. ${ }^{16,31,32} 0$ córtex do cíngulo anterior e a ínsula anterior, que inclui uma região chamada frontoínsula localizada na transição para o córtex orbitofrontal, fazem parte da rede de saliência e são particularmente vulneráveis à neurodegeneração na vcDFT. Em tais regiões, observa-se atrofia em fases iniciais da doença. ${ }^{33}$

\subsubsection{Variante semântica da Afasia Progressiva Primária}

É uma síndrome clínica caracterizada por distúrbio de linguagem fluente, com perda progressiva do conhecimento de palavras (levando a anomia e dificuldade de compreensão de palavras), e presença de parafasias semânticas. ${ }^{1,34}$ Os pacientes podem apresentar dificuldade para reconhecer objetos (particularmente itens pouco frequentes ou com os quais estão menos familiarizados) e sinais de dislexia e/ou disgrafia de superfície (que são caracterizadas por erros na escrita ou leitura de palavras irregulares) ${ }^{2}$

O início dos sintomas ocorre mais frequentemente entre os 65-70 anos (variando entre 50-80 anos), com distribuição similar entre homens e mulheres (ou com leve predomínio em homens). ${ }^{20,34}$ A sobrevida é mais longa do que na vcDFT, com mediana entre 8 a 12 anos. ${ }^{34}$

A doença leva a um comprometimento assimétrico dos lobos temporais anteriores, com quadro clínico diferente a depender do lado mais acometido. Nos casos de vsAPP de predomínio à esquerda o quadro clínico é o distúrbio de linguagem 
citado acima. Após alguns anos de evolução do distúrbio de linguagem (em média três anos), podem aparecer sintomas comportamentais similares aos observados na vcDFT. Nos casos em que o predomínio é temporal anterior direito (variante temporal direita, que alguns autores sugerem que seja considerada outra forma clínica da vcDFT), ${ }^{35}$ a síndrome clínica é caracterizada por alterações comportamentais (mudança de personalidade, depressão, comportamento social inapropriado) com perda de crítica. Nesses casos, pode haver ainda prosopagnosia, topografagnosia e agnosia associativa. Os casos com predomínio à esquerda parecem ser mais frequentes do que os casos com predomínio à direita, porém isso pode ocorrer por viés de encaminhamento (sendo os pacientes com a variante temporal direita mais frequentemente encaminhados para avaliação psiquiátrica). ${ }^{16,36}$

Os estudos de neuroimagem na vsAPP mostram consistentemente atrofia temporal anterior assimétrica, especialmente dos córtices polar, peririnal e giro fusiforme anterior (com estudos de neuroimagem funcional demonstrando padrão de hipometabolismo concordante). ${ }^{34,37}$

De acordo com os critérios diagnósticos de APP, em primeiro lugar se deve fazer o diagnóstico de APP com base nos critérios listados na Tabela $2 .^{2}$ Após essa primeira etapa, deve-se seguir para o diagnóstico da variante da APP. No caso da vsAPP, os critérios estão descritos na Tabela 3.

Tabela 2 - Critérios de Inclusão e Exclusão para o diagnóstico de Afasia Progressiva Primárias

\section{Critérios de Inclusão: os três devem estar presentes}

1. O sintoma mais proeminente é a dificuldade com linguagem

2. Esses déficits são a causa principal de limitação nas atividades de dia diária

3. Afasia deve ser o déficit mais proeminente no início dos sintomas, e nas fases iniciais da doença

\section{Critérios de exclusão: os quatro devem estar ausentes}

1. Os déficits são melhor explicados por doenças não degenerativas do sistema nervoso, ou por doenças clínicas;

2. O distúrbio cognitivo é melhor explicado por diagnóstico psiquiátrico;

3. Perda de memória episódica, memória visual, ou declínio nas habilidades visuoperceptivas como sintomas proeminentes iniciais;

4. Distúrbio comportamental proeminente no início do quadro. 
Tabela 3 - Critérios diagnósticos da variante semântica da Afasia Progressiva Primária

\section{Diagnóstico Clínico de vsAPP}

Ambos critérios centrais devem estar presentes:

- Comprometimento da nomeação por confrontação;

- Comprometimento na compreensão de palavras isoladas.

Ao menos 3 das seguintes características devem estar presentes:

- Comprometimento do conhecimento de objetos;

- Dislexia ou disgrafia de superfície;

- Repetição preservada;

- Produção de fala preservada (gramática e aspectos motores da fala).

\section{Diagnóstico de vsAPP com suporte de neuroimagem}

Ambos critérios devem estar presentes

- Diagnóstico clínico de vsAPP;

- Neuroimagem deve mostrar uma ou mais dos seguintes achados:

- Atrofia predominante no lobo temporal anterior;

- Hipoperfusão ou hipometabolismo predominante no lobo temporal anterior. Referência: Gorno-Tempini et al., 20112

\subsubsection{Variante não fluente da Afasia Progressiva Primária}

A vnfAPP é caracterizada por fala espontânea não fluente, com presença de agramatismo e/ou apraxia da fala, parafasias fonêmicas e anomia. ${ }^{2,38}$ Agramatismo é caracterizado por simplificação das formas gramaticais, com presença de erros e omissões gramaticais. Os sintomas podem se iniciar com redução da produção de palavras, redução do comprimento de frases e dificuldade na compreensão de frases sintaticamente complexas. Os pacientes com vnfAPP falam em média menos de 45 palavras por minuto, o que representa menos do que um terço do normal. ${ }^{38}$ Alguns pacientes apresentam dificuldade no planejamento articulatório das palavras, denominada apraxia da fala, e na avaliação neuropsicológica podem apresentar também sinais de disfunção executiva e déficit em memória operacional.

Apesar das dificuldades de linguagem, os pacientes podem manter a funcionalidade e independência por alguns anos. Com a progressão da doença, podem se associar às dificuldades de linguagem quadro extrapiramidal compatível 
com paralisia supranuclear progressiva (PSP) ou síndrome corticobasal (SCB), ou ainda mudanças comportamentais como vistas na vcDFT. 1,16,38

O início dos sintomas é, de modo geral, mais tardio que nas outras formas de vcDFT, com idade média de início de 63₫9,7anos, e a evolução clínica parece ser mais longa que na vcDFT. ${ }^{20}$

Observa-se atrofia perisilviana do hemisfério dominante como achado principal de neuroimagem, particularmente das regiões opercular, insular e inferior do lobo frontal esquerdo. 2,38

Os critérios diagnósticos da vnfAPP estão na Tabela $4 .^{2}$

Tabela 4 - Critérios diagnósticos da variante não fluente da Afasia Progressiva Primária

Diagnóstico Clínico de vnfAPP

Ao menos um dos critérios centrais deve estar presente:

- Agramatismo;

- Apraxia da fala.

Ao menos 2 das seguintes características devem estar presentes:

- Comprometimento da compreensão de frases complexas;

- Preservação da compreensão de palavras isoladas;

- Preservação do conhecimento de objetos.

\section{Diagnóstico de vnfAPP com suporte de neuroimagem}

Ambos critérios devem estar presentes

- Diagnóstico clínico de vnfAPP;

- Neuroimagem deve mostrar uma ou mais dos seguintes achados:

- Atrofia predominante na região frontoinsular posterior esquerda;

- Hipoperfusão ou hipometabolismo predominante na região frontoinsular posterior esquerda.

Referência: Gorno-Tempini et al., 20112

\subsection{Neuropatologia da Degeneração Lobar Frontotemporal}

Enquanto o termo DFT tem sido usado nos últimos anos para englobar as síndromes clínicas que são descritas nas doenças em que a degeneração predomina nos lobos frontais e/ou temporais do cérebro, o termo Degeneração Lobar Frontotemporal (DLFT) tem sido empregado na classificação neuropatológica desde grupo de doenças. 
Macroscopicamente, encontra-se na DLFT atrofia circunscrita e em geral assimétrica dos lobos frontais e/ou temporais. O padrão de atrofia é variável e se correlaciona com a síndrome clínica apresentada - ou seja, atrofia frontal bilateral na vcDFT, atrofia temporal anterior na vsAPP e atrofia perisilviana no hemisfério dominante na vnfAPP. ${ }^{39}$ Microscopicamente, encontra-se degeneração microvacuolar e perda de células piramidais nos córtices frontal e temporal, causando aspecto espongiforme predominante nas camadas superficiais do córtex cerebral. Graus variados de gliose, perda axonal e de fibras mielinizadas, presença de corpúsculos de inclusão e neurônios balonados também podem ser observados. ${ }^{16}$

A classificação neuropatológica das DLFTs baseia-se na proteína agregada encontrada nas inclusões neuronais e/ou gliais. Atualmente são reconhecidos três grupos neuropatológicos de DLFT: DLFT-tau, DLFT-TDP e DLFT-FUS. ${ }^{40}$

A DLFT-TDP é caracterizada por inclusões intracitoplasmáticas e intranucleares de TDP-43 hiperfosforilada, e é a forma mais frequentemente encontrada (em cerca de $50 \%$ dos casos de DLFT). ${ }^{41}$ Ela é subdividida em quatro subtipos ( $A, B, C$ e $D$ ), e cada subtipo está associado a uma ou mais síndromes clínicas e, em algumas situações, a mutações em genes causadores de DLFT (Tabela 5). Inclusões com TDP-43 anormal também podem ser encontradas na ELA.

Inclusões neuronais e/ou gliais imunorreativas a anticorpo contra a proteína tau hiperfosforilada são encontradas na DLFT-tau. A DLFT-tau pode se manifestar clinicamente como vcDFT, vnfAPP, PSP ou SCB, e é a alteração neuropatológica encontrada em casos de mutações do gene MAPT (que codifica a proteína tau associada a microtúbulos). ${ }^{40,41}$ Os subtipos de DLFT-tau conhecidos atualmente são: doença de Pick, degeneração corticobasal, paralisia supranuclear progressiva, doença de grãos argirofílicos, taupatia de múltiplos sistemas com demência, demência com predomínio de emaranhados neurofibrilares e taupatia de substância branca com inclusões globulares gliais. ${ }^{40}$

A DLFT-FUS é encontrada em 5-10\% dos casos de DLFTs. ${ }^{40,41}$ São descritas três formas de DLFT-FUS: doença com corpúsculos de inclusão basofílicos, doença com inclusão de neurofilamentos intermediários, e a denominada DLFT atípica. ${ }^{40} \mathrm{~A}$ DLFT atípica tem uma apresentação clínica particular e se caracteriza clinicamente por vcDFT de início precoce (em média 40 anos), com frequência aumentada de 
sintomas psicóticos. ${ }^{42} \mathrm{Na}$ neuroimagem observa-se atrofia de núcleo caudado como marcador precoce da doença. ${ }^{43}$

Além desses três grupos principais, há dois outros grupos em que a proteína patológica principal ainda não foi identificada: DLFT-U e DLFT sem inclusões. Na DLFT-U observa-se inclusões imunocoradas por anticorpos contra proteínas do sistema ubiquitina-proteassoma como achado principal, porém tais alterações não são imunorreativas a anticorpos contra tau hiperfosforilada, TDP-43 ou FUS. A DLFT-U é encontrada nos casos de mutações do gene CHMP2B. Na DLFT sem inclusões (previamente denominada demência sem histopatologia distinta ou dementia lacking distinctive histopathology - DLDH), não há alterações imunocoradas com anticorpos contra proteínas do sistema ubiquitina-proteassoma, tau hiperfosforiladas, TDP-43 ou FUS. 40

Tabela 5 - Subtipos da DLFT-TDP e correlações com clínica e genética

\begin{tabular}{|c|c|c|c|}
\hline Subtipo & Patologia cortical & $\begin{array}{l}\text { Fenótipos } \\
\text { associados }\end{array}$ & $\begin{array}{l}\text { Mutações } \\
\text { associadas }\end{array}$ \\
\hline A & $\begin{array}{l}\text { INC frequentes } \\
\text { ND curtos frequentes } \\
\text { Alterações predominantemente } \\
\text { na camada } 2\end{array}$ & $\begin{array}{l}\text { vcDFT } \\
\text { vnfAPP }\end{array}$ & $G R N$ \\
\hline B & $\begin{array}{l}\text { ICN em quantidade moderada } \\
\text { ND esparsos } \\
\text { Todas as camadas }\end{array}$ & $\begin{array}{l}\text { vcDFT } \\
\text { vcDFT com DNM }\end{array}$ & C9orf72 \\
\hline C & $\begin{array}{l}\text { ND longos frequentes } \\
\text { INC esparsas } \\
\text { Alterações predominantemente } \\
\text { na camada } 2\end{array}$ & $\begin{array}{l}\text { vsAPP } \\
\text { vcDFT }\end{array}$ & \\
\hline D & $\begin{array}{l}\text { DN curtos frequentes } \\
\text { INIs frequentes } \\
\text { INC esparsas } \\
\text { Todas as camadas }\end{array}$ & $\begin{array}{l}\text { Miopatia com } \\
\text { corpúsculos de } \\
\text { inclusão, doença de } \\
\text { Paget óssea e vcDFT }\end{array}$ & VCP \\
\hline
\end{tabular}

Legenda: INC: inclusões neuronais intracitoplasmáticas; ND: neuritos distróficos; INI: inclusões neuronais intranucleares. Referência: Mackenzie et al., 2011.44

\subsection{Genética da DLFT}


A DLFT tem um componente genético importante, o que pode ser observado pelo fato de que cerca de $40 \%$ dos pacientes têm antecedente familiar de doenças do espectro das DFTs e cerca de 10-15\% apresentam história familiar de DFT com padrão de herança autossômico dominante. ${ }^{45-48}$ Dentre as variantes da DFT, a vcDFT é a que mais frequentemente e a vsAPP é a que menos frequentemente apresentam agregação familiar, com mais de um indivíduo acometido na mesma família. ${ }^{47-51}$ História familiar com padrão autossômico dominante em geral é mais frequente na vcDFT sem DNM do que na vcDFT com DNM. ${ }^{48,49,51}$

Desde a identificação de mutações no gene da proteína tau associada a microtúbulos (MAPT) como causadora de DFT familial em 1998, ${ }^{52}$ mutações em mais de dez outros genes foram identificadas, como no gene da progranulina ( $G R M)$, em 2006, e no gene C9orf72 (Chromosome 9 open reading frame 72), em 2011.53-55 O conhecimento sobre a genética das DLFTs tem crescido exponencialmente nos últimos anos, mas ainda há muito o que ser descoberto e outros genes devem ser identificados no futuro, uma vez que até $60 \%$ das famílias com DFT não apresentam mutações nos genes atualmente conhecidos. ${ }^{51,56}$

Existem importantes ligações entre as doenças do espectro das DLFTs e as DNM. Clinicamente, isso se caracteriza pela co-ocorrência de DFT e DNM em pacientes (na forma de DFT-DNM) e pela existência de famílias cujos indivíduos desenvolvem DFT, DNM ou DFT-DNM. ${ }^{16}$ Do ponto de vista neuropatológico, inclusões com proteínas TDP-43 e FUS anormais também são encontradas em casos de DNM. ${ }^{57}$ Do ponto de vista genético, existem mutações em genes que estão associadas tanto a DFT quanto a DNM/ELA. As mutações mais frequentes que causam DFT e DNM familial são as expansões de hexanucleotídeos no gene C9orf72, mas mutações em outros genes como o gene da proteína TDP-43 (TARDBP) e o gene da proteína FUS (FUS) também causam doenças do espectro das DLFT-DNM. Vários dos genes associados às doenças deste espectro codificam proteínas que participam de vias de degradação de proteínas, por autofagia e/ou pelo sistema ubiquitinaproteasoma, como a FUS, TDP-43, e UBQLN2. ${ }^{58}$

Outros genes, dentre os quais o gene da proteína que contém valosina $(V C P)$, estão associados a um fenótipo complexo denominado de proteinopatia multisistêmica. ${ }^{59} \mathrm{~A}$ proteinopatia multisistêmica é uma síndrome rara caracterizada por acometimento de encéfalo, neurônios motores, músculos e ossos, e clinicamente 
se apresenta em famílias cujos indivíduos apresentam combinações dos seguintes fenótipos: vcDFT, DNM, doença de Paget óssea e/ou miopatia com corpúsculos de inclusão. ${ }^{60}$

Além das formas monogênicas da DLFT, alguns estudos têm tentado identificar genes associados às formas esporádicas, ou poligênicas, das DLFTs. A heterogeneidade neuropatológica da DLFT, e a falta de biomarcadores que permitam o diagnóstico neuropatológico do tipo de DLFT durante a vida têm dificultado a realização de estudos de associação genômica neste grupo de doenças. Mas alguns estudos de associação genômica ampla realizados recentemente conseguiram identificar alguns genes e potenciais vias fisiopatológicas e serão comentados adiante. ${ }^{61,62}$

A frequência de mutações em genes associados à DFT ainda não foi determinada no em casuísticas brasileiras, mas alguns pacientes e famílias com mutações já foram publicados. ${ }^{63-65}$

\subsubsection{Genes associados às formas monogênicas da DLFT}

\subsubsection{Gene MAPT}

Gene e proteína. O gene MAPT localiza-se no cromossomo 17q21.1 e é composto por 16 éxons, dos quais apenas onze são expressos no sistema nervoso central (1-5,7,9-13). ${ }^{66}$ A proteína tau faz parte da família das proteínas associadas a microtúbulos, e tem a função de estabilizar e promover a montagem de microtúbulos. ${ }^{67}$ A hiperfosforilação da proteína tau e seu acúmulo na forma de filamentos insolúveis no cérebro caracterizam as denominadas taupatias, ${ }^{68}$ que possuem como característica histopatológica principal a presença de inclusões neuronais e gliais imunorreativas a tau hiperfosforilada.

No encéfalo normal há seis isoformas da proteína tau, geradas a partir do splicing alternativo dos éxons 2,3 e $10 .{ }^{69}$ Os éxons 9 a 12 codificam os domínios que se ligam aos microtúbulos, e dependendo da inclusão ou exclusão do éxon 10 nos transcritos, as isoformas podem ter três (3R) ou quatro repetições (4R) desses 
domínios. No encéfalo normal, as isoformas $3 R$ e $4 R$ coexistem em igual proporção (1:1), e acredita-se que mudanças nessa proporção levam a neurodegeneração. 52,69 Nas taupatias pode haver predomínio da isoforma com 3R (como na doença de Pick), ou 4R (como na demência com grãos argirofílicos, PSP e degeneração corticobasal), ou ainda em combinação ( $3 R+4 R$, como na $D A) .{ }^{70}$ Os éxons 2 e 3 codificam regiões no amino-terminal que estão envolvidas com interações com a membrana plasmática e espaçamento entre microtúbulos..$^{71,72}$

Mutações patogênicas. As mutações patogênicas de MAPT podem ser divididas em dois grupos, com mecanismos patogênicos distintos. ${ }^{52,69,73} \mathrm{O}$ primeiro grupo, composto por mutações missense e deleções, modifica a proteína tau e sua função, de modo a aumentar ou diminuir sua interação com os microtúbulos. Algumas dessas mutações podem levar a aumento na tendência da tau em formar filamentos, que ao formar agregados se tornam neurotóxicos. ${ }^{74} \mathrm{O}$ segundo grupo de mutações (localizadas no éxon 10 ou na região intrônica localizada próximo ao ponto de corte 5' do éxon 10) interfere no splicing alternativo do éxon 10, com mudança na proporção entre tau 3R e 4R (aumentando a proporção de 4R), o que leva a um aumento de inclusões filamentosas e está relacionado a neurodegeneração. ${ }^{69} \mathrm{~A}$ proteína tau se acumula no citoplasma, é hiperfosforilada, torna-se insolúvel e forma filamentos, mas a ordem desses eventos ainda não é bem compreendida. ${ }^{75}$

A maior parte das mutações patogênicas do gene estão agrupadas nos éxons 9-13 (com exceção de duas mutações no éxon 1), que codificam as regiões de ligação com microtúbulos e regiões flanqueadoras (Figura 1). ${ }^{76,77}$

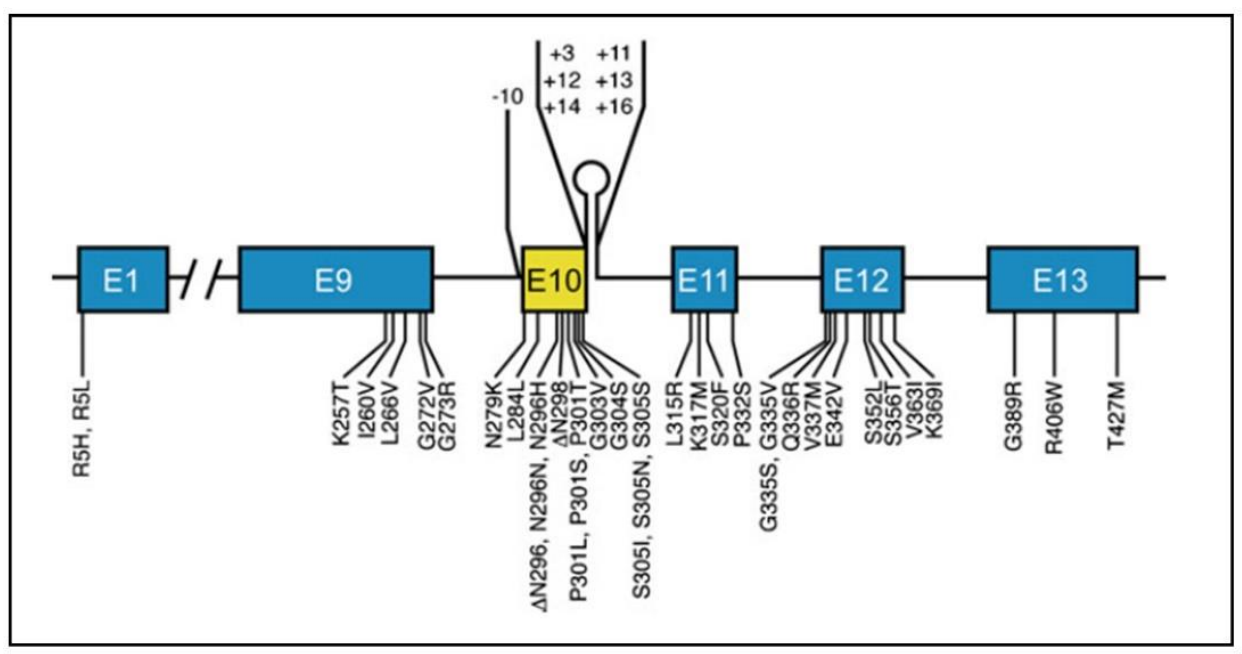

Figura 1 - Mutações em MAPT ${ }^{76}$ 
Até o momento foram identificadas mais de 44 mutações patogênicas do gene (missense, deleções, silenciosas ou mutações intrônicas), em 134 famílias. ${ }^{77} \mathrm{Em}$ casuísticas de DFT com mais de 100 pacientes, mutações em MAPT foram encontradas em $3-11 \%$ dos casos, variando entre 9-38\% em casos de DFT familial e 0-3\% em casos de DFT esporádica. ${ }^{48,49,54,78-85}$ As mutações mais comumente relatadas na literatura são: p.P301L (em 32 famílias) e IVS10+16C>T (em 27 famílias). ${ }^{77,80}$ Mutações em MAPT causam doença com padrão de herança autossômico dominante, e penetrância maior que $95 \% .45,86$

Aspectos clínicos. Existe grande variabilidade fenotípica nas mutações deste gene. A idade média de início dos sintomas, por exemplo, varia entre 46 e 57 anos nas diversas casuísticas, e a idade de início dos sintomas já foi relatada entre 17 a 75 anos. ${ }^{78,79,87}$ Mas de modo geral, o início dos sintomas ocorre antes dos 65 anos de idade, e início após os 70 anos é raro. ${ }^{49,78,88} \mathrm{O}$ aparecimento de sintomas na segunda ou terceira décadas de vida também é raro, mas foi descrito em algumas mutações como p.G389R e p.G335V. ${ }^{77,78,88} \mathrm{~A}$ duração da doença até o óbito também é variável, e em média é de 8 a 10 anos, mas já foram descritos casos com duração total de doença variando entre um e 25 anos. A mutação p.R406W tem sido associada a duração mais longa de sintomas. ${ }^{78-80,88,89}$

VcDFT, com ou sem parkinsonismo, é o fenótipo mais frequentemente relatado em mutações de MAPT (em mais de $85 \%$ dos casos). ${ }^{49,78,79}$ PSP $78,90,91$ e vsAPP 80,92 também são relativamente frequentes, seguidos por SCB ${ }^{93}$, vnfAPP ${ }^{78}$ e demência do tipo Alzheimer de início precoce ${ }^{94-97}$ como fenótipos menos frequentemente descritos. O fenótipo de DA foi descrito em pacientes com mutações p.R406W e IVS10+16C>T, mas em nenhum dos casos descritos até o momento, o diagnóstico neuropatológico foi de DA. ${ }^{94-97}$. Apenas um caso de atrofia cortical posterior foi relatado, com a mutação p.V363I. ${ }^{98}$

Parkinsonismo é relatado em $25-56 \%$ dos casos, e distúrbios da motricidade ocular extrínseca, em 13-29\% dos pacientes. ${ }^{78,79,99}$ Anormalidades da motricidade ocular extrínseca parece ser um diferencial entre mutações de MAPT, e de GRN ou C9orf72, pois são raras nestes dois últimos..$^{78,79}$

A presença de DNM é rara em mutações de MAPT. Duas famílias com a mutação p.K317M foram descritas com fenótipo de vcDFT, parkinsonismo e DNM. ${ }^{100}$ 
Recentemente, uma nova mutação (p.D348G) foi encontrada em cinco pessoas de uma família com doença do neurônio motor inferior e falência respiratória, mas sem sinais de comprometimento cognitivo. ${ }^{101}$ Hipoventilação progressiva também foi relatada na única família descrita até o momento com mutação homozigótica em MAPT (p.S352L). ${ }^{102}$

Neuroimagem. Estudos de neuroimagem estrutural têm mostrado que, em indivíduos sintomáticos com mutação em MAPT, a atrofia é mais significativa em regiões temporais anteromediais. ${ }^{103,104} \mathrm{Um}$ estudo sugeriu que mutações que afetam o splicing alternativo do éxon 10 (como a IVS10+16 e a p.N279K) tendem a apresentar um padrão de atrofia que predomina em lobos temporais mesiais, enquanto que mutações que alteram a estrutura da proteína (como a p.P301L), estão associadas a perda de substância cinzenta nas porções laterais dos lobos temporais. ${ }^{105}$ Atrofia também é observada nos lobos frontais, particularmente nas regiões orbitofrontais, e é tipicamente simétrica (contrastando com a assimetria encontrada em mutações de $G R M$. ${ }^{103}$ Atrofia em lobos parietais pode ser encontrada, mas é menos significativa do que a observada em mutações de GRN ou C9orf72. 104,106

Neuropatologia. As alterações neuropatológicas descritas em mutações de MAPT são heterogêneas, mas caracteristicamente se observam inclusões neuronais, ou gliais e neuronais, compostas por tau hiperfosforilada. ${ }^{75}$ Mutações localizadas nos éxons 9, 11, 12 e 13 geralmente estão associadas a inclusões em neurônios que contêm predominantemente tau $3 R$, enquanto que as localizadas nos éxons 1 e 10 , ou nos introns próximos aos éxons 9 e 10, tendem a gerar inclusões em neurônios e células da glia com predomínio de isoformas com $4 \mathrm{R} .{ }^{75}$ As inclusões neuronais podem se assemelhar a corpúsculos de Pick ou emaranhados neurofibrilares, enquanto que as inclusões gliais podem se apresentar como corpúsculos em embrião, astrócitos em tufo e/ou placas astrocíticas ${ }^{75}$.

Variantes de risco em MAPT. Os haplótipos $\mathrm{H} 1 / \mathrm{H} 2$ incluem o gene MAPT e têm sido estudados como fatores de risco para taupatias, pois parecem afetar o splicing alternativo dos éxons 10 e/ou 3. ${ }^{73,107,108} \mathrm{O}$ haplótipo H2 é o menos comum e é caracterizado por uma inversão de cerca de $900 \mathrm{~kb}$ em relação à sequência do haplótipo H1. ${ }^{109}$ Ele é encontrado no mundo todo, mas com frequência maior no sul da Europa, sudeste da Ásia e norte da África. ${ }^{109}$ A associação mais consistentemente encontrada é entre o haplótipo H1 e risco aumentado para PSP, ${ }^{110,111}$ e há evidências 
que indicam esse haplótipo como fator de risco para degeneração corticobasal e doença de Parkinson. ${ }^{112-115}$ Alguns estudos demonstraram maior frequência do alelo H1/genótipo H1H1 em pacientes com DFT, em relação a controles. ${ }^{116,117}$ No entanto, essa associação não foi encontrada em outros estudos, o que torna-a discutível ou não muito significativa. ${ }^{118,119}$ Os estudos que investigaram associação do haplótipo com DA também não obtiveram resultados consistentes. ${ }^{120,121}$

Uma variante rara localizada no éxon 7 (p.A152T) foi associada a aumento de risco de doenças do espectro das DFTs (como vcDFT, vnfAPP, PSP e SCB) e de DA em estudos recentes. ${ }^{122,123}$ Essa variante está localizada em uma região do gene diferente daquelas onde são descritas mutações patogênicas do gene. Estudos funcionais indicaram que essa variante está associada a redução da interação da tau com microtúbulos e aumento da formação de oligômeros tóxicos de tau. ${ }^{123}$

\subsubsection{Gene GRN}

Estudos de linkage em famílias com DFT apontavam uma região no cromossomo 17 (17q21) que continha cerca de 165 genes. Após a identificação do gene MAPT, observou-se que algumas dessas famílias não tinham mutações no gene MAPT e não apresentavam achados neuropatológicos de DLFT-tau, o que sugeria que outro gene naquela região cromossômica também estava associado a DFT. Apenas em 2006 (ou seja, oito anos após a descoberta de mutações em MAPT), e sequenciamento de mais de 80 dos genes da região é que mutações no gene da progranulina (GRM) foram identificadas como causadoras de DFT. ${ }^{53,124}$

Gene e proteína. O gene se localiza na região 17q21.32 e é formado por 13 éxons, dos quais o éxon 1 não codifica proteína. $O$ gene codifica a proteína progranulina, de 593 aminoácidos, que pode ser clivada em peptídeos de granulina $\left(A, B, C, D, E, F\right.$, e P). ${ }^{125}$ A progranulina é expressa principalmente em células epiteliais e hematopoéticas; e no sistema nervoso, é expressa em neurônios e micróglia. A proteína tem propriedades neurotróficas como fator de crescimento e de sobrevivência neuronal (protegendo neurônios de insultos tóxicos em modelos laboratoriais). Além disso, ela participa de processos inflamatórios (como cicatrização, 
ativação da micróglia e inibição de TNF- $\alpha$ ), tumorigênese, e está aumentada no diabete melito e na resistência à insulina. ${ }^{125-127}$

Mutações patogênicas. As mutações patogênicas de GRN levam a perda de função, e causam doença por haploinsuficiência. ${ }^{53,128}$ As mutações nulas em GRN em geral são do tipo nonsense ou inserções ou deleções que geram mutações do tipo frameshift, com formação de códon de parada prematuro e decaimento de RNA mensageiro mediado por mecanismo nonsense. As deleções ou inserções de nucleotídeos em número não múltiplo de três levam a uma mudança na matriz de leitura dos códons (frameshift), ocasionando mudanças na tradução da proteína e frequentemente levando à ocorrência de um códon de parada precoce. Mutações localizadas em sítios de iniciação de tradução ou de splicing, e deleções (parciais e totais) do gene também foram descritas. ${ }^{125,129-131}$ Mutações missense também foram descritas, mas em poucas delas há evidência de patogenicidade - afetando a produção, secreção ou função da progranulina - demonstrada por estudos funcionais, dentre as quais: p.A9D, p.C139R, p.R432C, e p.C521Y. ${ }^{132-134}$

Modelos animais e de culturas de células têm mostrado que a deficiência de progranulina provoca redução na densidade sináptica, redução da sobrevida de neurônios, aumento da susceptibilidade de neurônios a estressores, e respostas inflamatórias anormalmente aumentadas, que podem ser os mecanismos subjacentes à neurodegeneração. ${ }^{125,135}$ No sangue de pacientes com mutações nulas em GRN foram relatados níveis aumentados dos mediadores inflamatórios IL-6 e TNF- $\alpha$, o que corrobora a importância da inflamação na neurodegeneração associada a deficiência de progranulina. ${ }^{136,137}$

Já foram descritas mais de 69 mutações em 231 famílias, e as mais comumente relatadas são a p.R493X (em 43 famílias), p.T272Sfs*10 (em 35 famílias) e IVS1+5G>C (em 10 famílias) (Figura 2). ${ }^{77}$ Em casuísticas de DFT com mais de 100 pacientes, mutações em GRN foram encontradas em $4-12 \%$ dos casos. Em casos de DFT familial, a frequência de mutações variou entre $7-28 \%$ e em casos de DFT esporádica, entre 1-4\%.49,78-81,83,84,135,138 As mutações têm padrão de herança autossômico dominante, com penetrância estimada em $50-60 \%$ aos 60 anos e maior que $90 \%$ aos 70 anos. $^{84,138,139}$ 


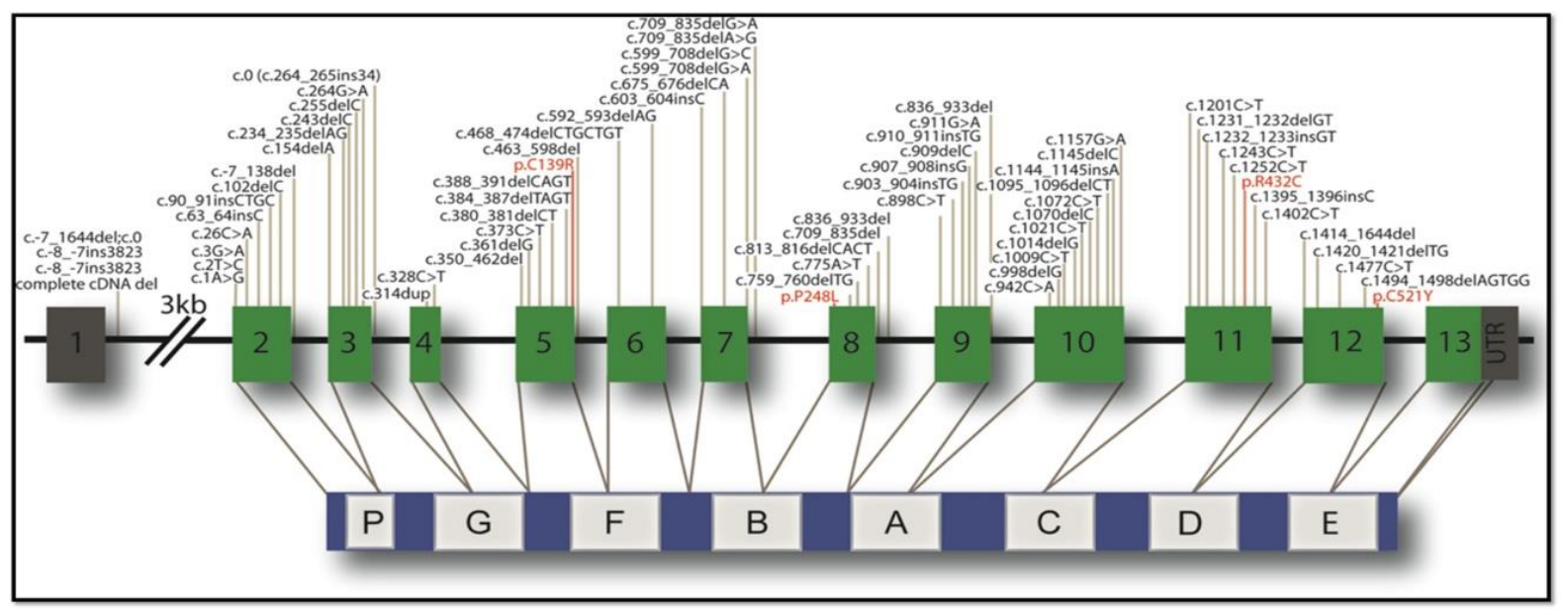

Figura 2 - Mutações em GRN ${ }^{126}$

Apresentação clínica. A idade média de início dos sintomas é de 46 a 57 anos nas casuísticas publicadas, com início variando entre 35 e 87 anos. ${ }^{49,78-81,84,127,135,138}$ Além da variabilidade fenotípica entre famílias, há grande variabilidade na apresentação clínica entre indivíduos da mesma família, com idade de início dos sintomas variando em até 20 anos. ${ }^{139} \mathrm{~A}$ duração dos sintomas da doença até o óbito é em média de 5 a 9 anos, e varia na literatura entre um a 23 anos. ${ }^{49,78-80,83,138}$

A apresentação clínica mais frequente em mutações de GRN é a vcDFT, que ocorre em cerca de $60-80 \%$ dos casos, seguida em frequência por vnfAPP e SCB. ${ }^{78,79,135,138,140}$ Mutações em GRN foram a causa mais frequente de SCB familial em algumas casuísticas. ${ }^{78,138}$ Outras variantes da APP, como a semântica e a mista, foram descritas em alguns casos. ${ }^{83,89,141}$ Fenótipos de demência do tipo Alzheimer, doença de Parkinson e demência com corpúsculos de Lewy são infrequentes; e apresentação de PSP é rara. $97,135,138,142,143$ Atrofia cortical posterior foi relatada em apenas um paciente. ${ }^{144} \mathrm{~A}$ apresentação de vcDFT com DNM também é rara, e foi relatada em poucos casos na literatura. ${ }^{84,138,140}$

Parkinsonismo é observado em $20-50 \%$ dos doentes. ${ }^{78,79,139} \mathrm{Um}$ grupo relatou frequência aumentada de alucinações visuais em indivíduos com mutações de GRN, em cerca de $25 \%$ dos casos, ${ }^{78}$ mas outros grupos não tiveram o mesmo achado, e encontraram frequência de alucinações e/ou psicose entre $5-12 \%$ dos casos. ${ }^{83,139}$ Além de sinais de disfunção executiva (típicos de vcDFT), a avaliação neuropsicológica pode demonstrar sinais de comprometimento dos lobos parietais, com disgrafia, discalculia, apraxia e/ou déficits visuoespaciais. ${ }^{83}$ 
Mutação em homozigose (p.T272Sfs ${ }^{*} 10$ ) foi relatada em dois irmãos com lipofuscinose ceróide neuronal de início adulto, indicando que mutações em homozigose de GRN levam a um fenótipo completamente diferente das mutações em heterozigose. Com a lipofuscinose ceróide neuronal é uma doença de acúmulo lisossomal, esse achado sugere que a progranulina participa de processos celulares relacionados aos lisossomos. ${ }^{145}$ Consistente com esse achado, um estudo encontrou níveis elevados de proteínas lisossomais (como CTSD, LAMP1 e LAMP2) e acúmulo de saposina $D$ e a SCMAS (subunidade $C$ da ATPase mitocondrial) em encéfalos de pacientes com mutações em GRN. ${ }^{146} \mathrm{O}$ acúmulo de saposina D e SCMAS é tipicamente observado na lipofuscinose ceróide neuronal. Este mesmo estudo relatou presença de TDP-43 hiperfosforilada em alguns encéfalos de pacientes com lipofuscinose ceróide neuronal. ${ }^{146}$

Neuroimagem. Estudos de neuroimagem estrutural indicam que a assimetria é mais significativa em mutações de $G R N$ do que em mutações de MAPT ou de C9orf72.83,104,147 A atrofia é mais proeminente em regiões temporais posteriores e parietais, mas também se estende aos lobos frontais. ${ }^{103}$ Tanto as regiões parietais mediais (pré-cuneo e cíngulo) quanto as laterais apresentam atrofia mais significativa em mutações de GRN do que de MAPT.

Hiperintensidades subcorticais periventriculares que indicam envolvimento da substância branca em imagens de ressonância magnética ponderadas em T2/FLAIR foram observadas em $20-40 \%$ dos pacientes, e encontradas principalmente em regiões de maior atrofia, como nos lobos frontais e parietais. ${ }^{148-150}$ As hiperintensidades podem ser confluentes, e comprometer as fibras em $U$, além da substância branca subcortical. ${ }^{150}$ Não se sabe ao certo o substrato neuropatológico dessas alterações, mas possivelmente estão relacionadas a focos de desmielinização e/ou ativação de micróglia. ${ }^{149,151}$

Progranulina como biomarcador. Mutações nulas de GRN levam a reduções nos níveis de progranulina no plasma e líquido cefalorraquidiano, tanto em indivíduos sintomáticos, quanto pré-sintomáticos. ${ }^{152-154}$ Mutações missense também podem estar associadas a níveis reduzidos de progranulina, similares aos das mutações nulas, ou em valores intermediários entre os encontrados em mutações nulas e em controles. ${ }^{154,155}$ Mas níveis normais de progranulina já foram relatados em pacientes com mutações missense (como a p.C521Y), ${ }^{134,155}$ o que seria um fator limitante ao 
uso de dosagem plasmática de progranulina como método de rastreio para mutações de $G R N$.

Neuropatologia. Mutações patogênicas em GRN levam a acúmulo de inclusões intracelulares de TDP-43 hiperfosforilada, e tipicamente se encontram no estudo neuropatológico de encéfalos de indivíduos com mutação em GRN características de DLFT-TDP tipo A (Tabela 5). ${ }^{44} \mathrm{O}$ mecanismo pelo qual a deficiência de progranulina leva à neurodegeneração e ao acúmulo de TDP-43 anormal no cérebro ainda não é conhecido. É possível que o acúmulo de TDP-43 anormal esteja relacionado a maior susceptibilidade a estressores externos que células nervosas apresentam na deficiência de progranulina, já que a proteína TDP-43 está envolvida em processos celulares ativados durante o estresse, como a formação de grânulos de estresse, e a solubilidade e agregação de TDP-43 se alteram durante o estresse celular. ${ }^{125,156}$

Variantes de risco em $G R N$. Entre os polimorfismos encontrados em $G R N$, o rs5848 é o que tem sido mais estudado. A variante rs5848 está localizada na região não traduzida 3' de GRN, e mais especificamente em um sítio de ligação do microRNA mi-659. ${ }^{157}$ Estudos in vitro mostraram que o alelo menor T de rs5848 facilita a ligação de mi-659 (em comparação com o alelo maior $\mathrm{C}$ ), o que resulta em inibição da tradução de GRN. Rademakers et al. demonstraram que indivíduos com o genótipo TT de rs5848 têm risco aumentado de desenvolver DLFT-TDP, com odds ratio de 3,18 (intervalo de confiança 95\% de 1,50-6,73) em relação a indivíduos com o genótipo CC. ${ }^{157}$ No entanto, estudos posteriores não conseguiram replicar associação de rs5848 em casuísticas de DFT diagnosticadas clinicamente. ${ }^{158,159} \mathrm{O}$ grupo holandês também não encontrou associação entre o genótipo de rs5848 e DLFT-TDP, em uma análise de subgrupo com 23 casos de DLFT-TDP. ${ }^{159}$

Estudos que investigaram associação entre o polimorfismo em rs5848 e DA e doença de Parkinson também encontraram resultados inconsistentes. Uma metaanálise publicada recentemente encontrou associação entre o genótipo TT e aumento de risco de DA apenas nos modelos homozigótico (TT vs. CC: odds ratio 1,36, com intervalo de confiança 95\% de 1,11-1,66, $\mathrm{p}=0,003$ ) e recessivo (TT vs. CC+CT: odds ratio 1,31, com intervalo de confiança $95 \%$ de 1,08-1,58, $\mathrm{p}=0,006)$. De modo similar, a associação com doença de Parkinson também só foi encontrada nos mesmos modelos, homozigótico (TT vs. CC: odds ratio 1,34, com intervalo de confiança 95\% 
$1,05-1,69$ e $\mathrm{p}=0,017$ ) e recessivo (TT vs. $\mathrm{CC}+\mathrm{CT}$ : odds ratio 1,28 , com intervalo de confiança $95 \% 1,02-1,60$ e $p=0,034){ }^{160}$.

\subsubsection{Genes associados ao espectro das DLFT-DNM}

\subsection{Gene C9orf72}

Expansões de hexanucleotídeos GGGGCC em região intrônica do gene C9orf72 foram descobertas em 2011 como causadoras de DFT, DFT-DNM e ELA por dois grupos independentes. ${ }^{54,55}$

Gene e proteína. O gene C9orf72 está localizado no cromossomo 9p21.1. A função da proteína C9ORF72 ainda não bem é conhecida, mas há evidências que sugerem que ela regule processos relacionados ao sistema endossomal e à autofagia, uma das vias de degradação de proteínas. ${ }^{161}$ A C9ORF72 também parece interagir com outras proteínas implicadas na DNM, como ubiquilina 2, hnRNPA1 e hnRNPA2/B1. ${ }^{161}$

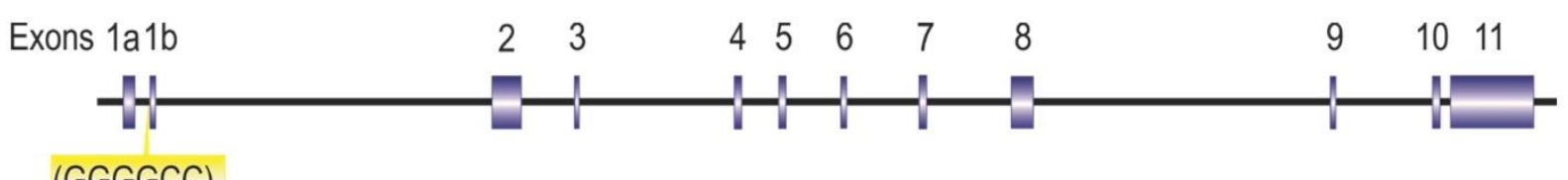

$($ GGGGCC)

Figura 3 - Estrutura do gene C9orf72 e localização da expansão (GGGGCC)n

Mutações patogênicas. Os mecanismos pelos quais as expansões de hexanucleotídeos GGGGCC levam a neurodegeneração ainda não estão completamente elucidadas, mas desde 2011 importante descobertas têm sido feitas. Uma das descobertas mais importantes foi que as repetições de hexanucleotideos formam proteínas com repetições de dipeptídeos (poliGA [glicina-alanina], poliGP [glicina-prolina], poliGR [glicina-arginina], poliPR [prolina-arginina] e poliPA [prolina- 
alanina]), através de tradução associada a repetições e não iniciada por ATG (em inglês: repeat-associated non-ATG-initiated translation, ou RAN translation). ${ }^{162,163}$

Três possiveis mecanismos patogênicos (não mutualmente excludentes) foram inicialmente considerados: redução da expressão de RNA mensageiro resultando em haploinsuficiência, toxicidade mediada por RNA, e/ou toxicidade causada por polipeptídeos. ${ }^{58,164}$

Diversos estudos demonstraram evidências de que o RNA mensageiro das repetições GGGGCC forma agregados no núcleo que sequestram proteínas que se ligam a RNA, afetando assim o splicing alternativo e o transporte de RNA mensageiro do núcleo para o citoplasma, e levando a neurodegeneração. ${ }^{165-168}$ Donnelly et al. conseguiram reverter parcialmente a excitotoxicidade induzida por glutamato em neurônios derivados de células-tronco pluripotentes induzidas com a mutação C9orf72 através do uso de oligonucleotídeos antisense que se ligam ao RNA com repetições GGGGCC. ${ }^{169}$

Dois estudos recentes indicaram que as proteínas com repetições de dinucleotídeos, e não o RNA, têm papel fundamental na neurodegeneração. Kwon et al. demonstraram que polímeros sintéticos com 20 repetições de PR e GR entravam em células, se ligavam a nucléolos e acabavam levando a morte celular. ${ }^{170}$ Além disso, os polímeros afetavam o splicing alternativo de RNA mensageiro (em padrão similar ao observado em pacientes com ELA) e a biogênese de RNA ribossomal. Mizielinska et al. demonstraram que as proteínas poliGR e poliPR com 36 ou 100 repetições causavam deformidades nos olhos de drosófilas (o que é indicativo de neurodegeneração) e morte precoce, enquanto que RNA com até 288 repetições não alterou o fenótipo. ${ }^{171}$ Esses estudos indicam que as proteínas com arginina são particularmente neurotóxicas; no entanto, não permitem descartar que RNA com repetições longas não possam causar ou participar da neurodegeneração. A possibilidade de que tanto RNA quanto proteínas participam do processo neurodegenerativo é sugerida por alguns estudos. Wen et al. observaram sinergismo na toxicicidade de transcritos com 42 repetições e de proteínas poliPR com 50 repetições em neurônios corticais. ${ }^{172}$

O mecanismo de haploinsuficiência foi inicialmente proposto pelo achado de níveis reduzidos de C9orf72 no cérebro de indivíduos com a mutação, e pela hipermetilação das ilhas CpG localizadas próximas à expansão. ${ }^{54,173}$ Mas estudos 
posteriores mostraram que a hipermetilação da expansão de repetições está associado a duração de doença mais longa, e menor acúmulo de focos de RNA e agregados de dipeptídeos, de modo que parece ser um mecanismo de proteção. ${ }^{174,175}$ Além disso, expansões de hexanucleotídeos em homozigose já foram encontradas, e diferentemente das mutações em que há perda de função (como no caso de $G R M$ ), o fenótipo foi similar às mutações em heterozigose. ${ }^{176,177}$

Desse modo, atualmente se acredita que a expansão de hexanucleotídeos em C9orf72 ou leva a neurodegeneração por duplo mecanismo, ou seja através da toxicidade mediada por RNA e também por polipeptídeos, ou apenas por toxicidade mediada por polipeptídeos. ${ }^{168}$

O número exato de repetições necessárias para causar doença ainda não foi estabelecido, devido ao fato de que as tecnologias atualmente disponíveis para sequenciamento não comportam sequências de milhares de pares de bases por leitura. Em geral, aceita-se 30 ou mais repetições de hexanucleotídeos como sendo patogênicas, apesar de que se estima que o número de repetições na maioria dos pacientes seja em torno de 700-4400.54,55,178,179 Em controles saudáveis, o número de repetições é tipicamente menor que $20-25 .{ }^{54,55}$ É possível que expansões de repetições de tamanho intermediário (entre 20 e 30, ou mais) possam estar associadas a aumento de risco de DFT, DNM, ou outras doenças neurodegenerativas como a doença de Parkinson. Isso foi sugerido pelos resultados de alguns estudos pequenos, que ainda precisam ser replicados em casuísticas maiores. ${ }^{180-182}$

Além da variabilidade fenotípica possivelmente associada ao número de repetições, variantes em outros genes, como PRNP, GRN, ATXN2 e TMEM106B parecem influenciar a apresentação da mutação, como idade de início dos sintomas e sobrevida. ${ }^{183-186}$

O padrão de herança observado nesta mutação é tipicamente autossômico dominante, mas a expansão já foi encontrada em homozigose, com fenótipo similar ao observado na expansão em heterozigose. ${ }^{176}$ A penetrância é alta, mas deve ser incompleta, uma vez que a mutação pode ser encontrada em idosos cognitivamente normais e estima-se que $0,1-0,2 \%$ da população normal tenha a expansão patológica. ${ }^{178,179,187}$ Um estudo multicêntrico estimou a penetrância em $58 \%$ aos 58 anos, e próxima a $100 \%$ aos 80 anos. ${ }^{178}$ 
As doenças causadas por expansões de repetições podem estar associadas ao fenômeno de antecipação. No caso das expansões em C9orf72, o estudo da antecipação é limitado pela falta de técnicas que permitam mensurar com precisão o número de expansões, como já mencionado. Outra dificuldade para estudos sobre antecipação (e penetrância) a ser melhor explorada no futuro é que a expansão é instável, e mesmo gêmeos monozigóticos, e amostras de tecido diferentes de um mesmo indivíduo podem ter expansões com números diferentes de repetições. ${ }^{179,183,188}$ Ademais, há evidências de que o mosaicismo seja dependente da idade, o que complica ainda mais a interpretação do número de repetições. ${ }^{183} \mathrm{De}$ qualquer modo, a análise de algumas casuísticas sugere que haja antecipação, com a idade de início dos sintomas em indivíduos de uma geração ocorrendo em média de 7 a 11 anos mais cedo do que na geração anterior. ${ }^{56,189,190}$

As casuísticas publicadas até o momento indicam que as expansões de hexanucleotídeos em C9orf72 são a causa mais genética mais comum de ELA, DFT e DFT-DNM, tanto esporádicas quanto familiais. ${ }^{164,178} \mathrm{Na}$ Europa, a mutação foi encontrada em $10 \%$ dos casos de DFT (18\% de DFT familial e 6\% de DFT esporádica) e em $9 \%$ de casos de ELA (37\% de ELA familial e 6\% de ELA esporádica). ${ }^{178,191} \mathrm{Na}$ presença de DNM (DFT-DNM), a frequência de mutações sobe para $56 \%$ dos casos familiais e $14 \%$ dos esporádicos. ${ }^{191}$ Mas a frequência da mutação varia muito de acordo com a população estudada, e é mais alta em países nórdicos, como a Finlândia (onde foi encontrada em $48 \%$ dos casos de DFT familial e $46 \%$ de ELA familial), e mais baixa em países asiáticos, como o Japão (uma casuística de 48 casos familiais e 27 esporádicos de DFT, PSP e CBS não identificou nenhum caso com a mutação) e Coréia do Sul. ${ }^{164,178,192,193}$ Acredita-se que os casos esporádicos sejam explicados por penetrância incompleta ou dependente da idade, ou ainda por informações incompletas sobre história familiar, já que expansões de novo não foram documentadas até o momento. ${ }^{164}$

Apresentação clínica. Os fenótipos mais comumente observados são vcDFT, DFT-DNM e ELA. ${ }^{54,55}$ Os três fenótipos podem aparecer em indivíduos de uma mesma família, mas uma mesma família pode ter apenas um ou dois desses fenótipos. Heterogeneidade fenotípica também é observada, com variação de mais de 20 anos na idade de início de sintomas e variação de duração de doença de mais de 10 anos, dentro de uma mesma família. ${ }^{190}$ 
O início dos sintomas da vcDFT ocorre em média entre 46 e 57 anos, variando entre 17 e 75 anos. 56,78,85,178,191,194-198 Clinicamente, a vcDFT causada pela mutação é de modo geral similar a dos casos esporádicos, mas o início pode ser um pouco mais precoce. ${ }^{56}$ Além disso, alguns estudos sugerem que sintomas psicóticos são mais frequentes em pacientes com a mutação do que em casos esporádicos, particularmente nas fases precoces da doença. ${ }^{197,199}$ O perfil neuropsicológico é típico da vcDFT, caracterizado por disfunção executiva, mas declínio de memória episódica e de habilidades visuoespaciais foram relatados em alguns pacientes. ${ }^{85,200}$ Parkinsonismo ocorre em $12-35 \%$ dos pacientes, e em frequência menor do que observado nos casos com mutações de MAPT ou GRN. ${ }^{78,79,81}$

APP não é uma apresentação comum das mutações de C9orf72, e representou de $0-20 \%$ dos casos de DFT em diferentes casuísticas. ${ }^{78,79,178,195-197}$ Mas tanto vsAPP e vnfAPP foram relatadas nesta mutação, inclusive associadas a DNM (APP-DNM).

DNM é encontrada em cerca de $30 \%$ dos casos de vcDFT e geralmente se apresenta como ELA, enquanto que atrofia muscular progressiva ou esclerose lateral primária são infrequentes. ${ }^{191,201,202}$ A idade média de início de ELA é de 56,8 anos, variando entre 27 a 89 anos, e é similar a casos esporádicos de ELA. ${ }^{178}$ ELA de início bulbar parece ser mais frequente entre pacientes com mutação, mas esse achado não é consistente nos estudos. ${ }^{178,203,204}$

Outros fenótipos além de DFT, DNM ou DFT-DNM são infrequentes ou raros nesta mutação. Foram descritos casos de DA, incluindo casos com confirmação neuropatológica, em indivíduos com expansões em C9orf72, mas na maior parte das casuísticas, a expansão foi encontrada em menos de $1 \%$ dos casos de DA, mesmo em casuísticas de DA de início precoce ou DA familial. ${ }^{97,179,205-208}$ Outros fenótipos foram descritos em poucos casos, ou como relatos de caso, como: doença de Parkinson (incluindo um com confirmação neuropatológica), ${ }^{209-213}$ SCB com ou sem ELA, ${ }^{212-214}$ PSP com ou sem ELA, ${ }^{212,213}$ demência com corpúsculos de Lewy, ${ }^{215}$ ataxia cerebelar, ${ }^{214,216}$ e ELA com esclerose múltipla. ${ }^{217}$ Expansões de repetições em C9orf72 também foram encontradas em cerca de $2 \%$ de pacientes diagnosticados com síndrome Huntington-like, e esta pode ser a mutação mais comum nesse grupo diagnóstico ${ }^{179,218}$. Em casuísticas alemãs de pacientes diagnosticados clinicamente com esquizofrenia, transtorno esquizoafetivo, ou transtorno afetivo bipolar, a expansão em C9orf72 foi encontrada em menos de $1 \%$ dos pacientes. ${ }^{219,220}$ 
A duração dos sintomas é variável, com médias relatadas entre 3 e 15 anos (e variação entre 1 e 24 anos). ${ }^{78,79,81,189,194-196} \mathrm{O}$ início dos sintomas por vezes é difícil de ser identificado com precisão, já que em alguns casos, mudanças comportamentais ocorrem insidiosamente ao longo de anos ou décadas antes que um diagnóstico de demência possa ser feito. ${ }^{64,190} \mathrm{~A}$ velocidade de progressão da doença também varia significativamente, e tanto formas lentamente quanto rapidamente progressivas de vcDFT causadas pela mutação em C9orf72 já foram descritas. ${ }^{221,222}$ A presença de DNM reduz a sobrevida da DFT, mas não há consenso na literatura se a mutação está associada a sobrevida mais longa ou mais curta do que casos esporádicos de DFTDNM. 194,223,224

Neuroimagem. A atrofia em casos de mutação de C9orf72 predomina nas regiões frontais, mas também acomete os lobos temporais e parietais. ${ }^{85,104,194} \mathrm{~A}$ atrofia em geral é simétrica, mas em alguns casos a atrofia pode ser mínima, particularmente no início da doença. ${ }^{81}$ Os lobos temporais são em geral menos acometidos do que nas mutações de GRN ou MAPT, e a atrofia parietal pode ser tanto medial quanto lateral.

Alguns estudos encontraram atrofia também no tálamo e cerebelo, incluindo um estudo de neuroimagem longitudinal. ${ }^{104,194,225}$ Consistente com a importância da patologia talâmica nesta mutação, um estudo de ressonância magnética funcional em repouso mostrou correlação entre a redução da conectividade da rede de saliência e atrofia no núcleo talâmico pulvinar medial esquerdo. ${ }^{226}$

Neuropatologia. Do ponto de vista neuropatológico, a mutação está associada a presença de inclusões TDP-43 positivas como as encontradas em DLFT-TDP tipo B e tipo A (isoladamente ou em conjunto). ${ }^{81,227}$ Após a descoberta da mutação, observou-se que havia no encéfalo de pacientes inclusões positivas para p62 mas negativas para TDP-43, particularmente na camada piramidal do hipocampo e camada de células granulares do cerebelo (estas últimas consideradas patognomônicas da mutação). ${ }^{228}$ Posteriormente, e com o uso de anticorpos contra proteínas com repetições de dipeptídeos (como poliGA, poliGP e poliGR), descobriuse que as inclusões p62 positivas e TDP-43 negativas continham essas proteínas com repetições de dipeptídeos. ${ }^{162,163}$ As inclusões com essas proteínas são predominantemente neuronais, e podem estar localizadas no núcleo ou no citoplasma. ${ }^{227}$ 
Existem relatos raros de casos em que foi observado acúmulo de proteínas com repetições de dipeptídeos, mas sem patologia TDP-43. 163,229 Esse achado indica que o acúmulo de TDP-43 anormal deva ocorrer mais tardiamente na fisiopatologia da doença causada pelas expansões em C9orf72, apesar de que parece haver correlação melhor entre o quadro clínico e a patologia TDP-43 do que a patologia das proteínas com repetições de dinucleotídeos. ${ }^{229,230}$ Não se conhecem bem as interações entre a expansão do gene e a proteína TDP-43, mas os resultados de um estudo realizado com culturas de células sugeriram que os polipeptídeos poliGA, poliGP e poliGR interferem com o sistema ubiquitina-proteasoma, o que pode afetar a homeostase da proteína TDP-43. ${ }^{231}$

Mutações coexistentes. Estudos recentes identificaram a presença de expansões de hexanucleotídeos de C9orf72 em pacientes que tinham mutações

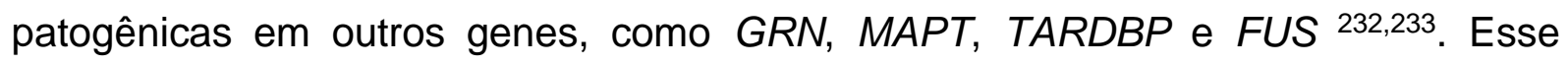
achado de mutações coexistentes é infrequente (menos que $2 \%$ dos casos em um estudo de DFT), mas pode alterar a apresentação clínica das mutações, como a idade de início dos sintomas. Em casos com mutações em GRN e C9orf72, os achados neuropatológicos mostraram características de ambas mutações. ${ }^{232,234}$

\subsection{Gene TARDBP}

Gene e proteína. O gene TARDBP está localizado no cromossomo 1p36.22 e codifica a proteína TDP-43 (transactive response [TAR]-DNA binding protein 43kDa). A TDP-43 é uma proteína que se liga a DNA e RNA, e que tem múltiplas funções no metabolismo de RNA, incluindo regulação da transcrição e tradução, splicing, transporte núcleo-citoplasmático, e formação de grânulos de estresse. . $^{58,235,236}$

Mutações patogênicas. Até o momento, foram encontradas 34 mutações patogênicas em 131 famílias, sendo as mutações descritas principalmente em casos familiais e esporádicos de ELA. ${ }^{77} \mathrm{~A}$ maior parte das mutações em TARDBP são missense (inserções, deleções e mutações nonsense foram encontradas em alguns casos) e localizadas no éxon 6 do gene, que codifica o carboxi-terminal, região envolvida com interação entre proteínas, regulação do splicing e localização celular da TDP-43. ${ }^{235,236}$ Células com inclusões citoplasmáticas imunocoradas com 
anticorpos contra TDP-43 tipicamente não apresentam TDP-43 no núcleo, local onde se observa TDP-43 na imunohistoquímica de células normais. Isso sugere que perda de função no núcleo e/ou efeitos tóxicos da proteína no citoplasma devem causar degeneração. Ambas possibilidades têm suporte pelas evidências disponíveis até o momento. 58

O padrão de herança é caracteristicamente autossômico dominante com penetrância incompleta, mas indivíduos com mutações em homozigose já foram relatados (com ELA, DFT-DNM com parkinsonismo, e um indivíduo assintomático de 67 anos de idade). ${ }^{233,236,237}$

Aspectos clínicos. Mutações em TARDBP causam cerca de $3 \%$ das formas familiais e 1,5\% das formas esporádicas de ELA, mas são causa infrequentes de DFT (com ou sem DNM), com menos de 20 probandos relatados na literatura com DFT ou demência. ${ }^{236,238}$ Dentro do espectro das DFTs, já foram descritos casos de DFT-DNM (p.G2955), vsAPP-DNM (p.G295S), vcDFT (p.N267S e p.A382T), SCB (p.N26S), e vsAPP (p.I383V). ${ }^{239-244}$ Floris et al. recentemente publicaram uma série de 5 probandos da Sardenha com a mutação p.A382T, e observaram que dentre os casos de DFT por mutações em TARDBP, apesar de o fenótipo vcDFT ser o mais frequentemente descrito, cerca de $30 \%$ apresentavam quadro de predomínio temporal (casos de variante temporal direita da vcDFT, vsAPP, ou ainda um quadro misto que denominaram de variante bitemporal da DFT). ${ }^{238}$ Existe grande variabilidade na idade de início dos sintomas, com relatos de casos de início entre os 29 e 77 anos de idade. ${ }^{238}$

Mutações também foram encontradas em pacientes com diagnóstico clínico de doença de Parkinson (p.N267S e p.A382T), ELA com parkinsonismo (p.A315E) e ELA com demência do tipo Alzheimer (p.G294V). ${ }^{245-248}$ Apresentações atípicas também foram descritas, como vcDFT com coréia e paralisia supranuclear do olhar (p.K263E) e anartria progressiva (p.S393L). ${ }^{249,250}$

Neuropatologia. Em casos DNM com mutações em TARDBP, mas sem comprometimento cognitivo, foram encontradas inclusões intracitoplasmáticas neuronais e gliais imunorreativas a anticorpos contra TDP-43 em neurônios motores superiores e inferiores, e em alguns casos também em outras regiões do encéfalo, como córtex, núcleos da base, amígdala e/ou núcleos do tronco encefálico. ${ }^{251}$ Apesar de se acreditar que as mutações em TARDBP aumentem a fosforilação de TDP-43, 
um estudo com a mutação p.N352S observou apenas raras inclusões com TDP-43 hiperfosforilada. ${ }^{251} \mathrm{Em}$ um caso de vsAPP com a mutação p.I383V, Gelpi et al. encontraram inclusões intracitoplasmáticas neuronais pequenas e neuritos curtos imunocorados com anticorpos contra ubiquitina e TDP-43 (com padrão que mais se aproximaria de DLFT-TDP tipo A), além de patologia tau em astrócitos e neurônios e inclusões com alfa-sinucleína no tronco encefálico e ínsula. ${ }^{242}$.

\subsection{Gene FUS}

Gene e proteína. O gene FUS está localizado no cromossomo 16p11.2, é composto por 15 éxons, e codifica a proteína fused in sarcoma (FUS). Essa proteína pertence a uma família de proteínas ligadoras a DNA/RNA, chamada de proteínas FET. ${ }^{252}$ A proteína FUS está envolvida em vários papéis relacionados ao metabolismo de RNA, incluindo regulação da transcrição, splicing, transporte núcleocitoplasmático, e formação de grânulos de estresse, além de reparo de DNA e proliferação celular. ${ }^{58,253}$

Mutações. Até o momento, são conhecidas 23 mutações patogênicas em 49 famílias. ${ }^{77}$ A maioria das mutações são missense, mas inserções e deleções (algumas causando mutações frameshift) também foram encontradas. ${ }^{253}$ As mutações no gene parecem causar neurodegeneração através de mecanismos tanto de ganho de função tóxica, já que a proteína FUS mutante e a hiperexpressão de proteína FUS normal parecem ser tóxicas em modelos animais, quanto de perda de função, pois a proteína mutante pode se ligar e suprimir as funções da FUS normal e de outras proteínas. ${ }^{58,253}$ As mutações localizadas no carboxi-terminal afetam o sinal de localização nuclear da proteína, levando a uma redistribuição da proteína do núcleo para o citoplasma, onde a FUS é recrutada para grânulos de estresse, se agrega, e forma inclusões. . $^{58,252-254}$

Aspectos clínicos. Mutações em FUS mais frequentemente se apresentam como DNM, e são encontradas em cerca de $5 \%$ dos casos familiais e $<1 \%$ dos casos esporádicos de ELA, incluindo ELA juvenil.. 236 Demência é considerada rara em mutações deste gene e foi relatada em poucas famílias. DFT-DNM e ELA-demência (com ou sem parkinsonismo) foi relatado em cinco famílias até o momento (p.G156E, p.G174-G175del, p.G206S, p.R521C, p.R521H), ${ }^{255-257}$ enquanto que vcDFT sem 
sinais de DNM foi descrito em apenas dois probandos com as mutações p.M254V e p.P106L (mas ainda faltam evidências funcionais de patogenicidade destas duas últimas mutações). ${ }^{241,253,258}$

Recentemente, variantes como p.Q290X (a única mutação nonsense descrita no gene), p.P431L e p.E377W foram encontradas em famílias com tremor essencial. ${ }^{259,260}$ Mas mutações em FUS parecem ser raras em tremor essencial, e a associação entre variantes em FUS e tremor essencial ainda precisa ser melhor estudada. ${ }^{253,261}$

Neuropatologia. A avaliação neuropatológica de casos de ELA com mutações em FUS mostra inclusões citoplasmáticas imunorreativas a FUS em neurônios e células da glia, mas existe variabilidade nos tipos de inclusões relatados em diferentes mutações, como a presença ou ausência de inclusões basofílicas. ${ }^{252,253}$

\subsection{Gene UBQLN2}

Gene e proteína. Em 2011 Deng et al. descreveram mutações no gene UBQLN2 (ubiquilina 2) em ELA com e sem demência. ${ }^{262} \mathrm{O}$ gene está localizado no cromossomo Xp11.21 e é formado por um único éxon. A ubiquilina 2 participa do sistema ubiquitina-proteasoma, que faz parte da via celular de degradação de proteínas, e mutações em UBQLN2 parecem comprometer a função desse sistema. ${ }^{262}$

Mutações patogênicas. O padrão de herança é dominante ligado ao X, de modo que tanto homens quanto mulheres podem ser afetados. ${ }^{262} \mathrm{~A}$ penetrância é alta, mas parece ser incompleta, considerando que Synofzik et al. descreveram um indivíduo assintomático aos 81 anos de idade. ${ }^{263}$

Aspectos clínicos. A idade de início é variável (mediana de 33 anos em homens e 44,5 anos em mulheres), mas parece ser significativamente menor em homens com a mutação. ${ }^{262}$ A maior parte dos carreadores desenvolvem ELA, mas alguns casos foram descritos com o fenótipo vcDFT-DNM. ${ }^{262}$ Mutações em UBQLN2 parecem ser raras em DFT, ${ }^{264-266}$ e há apenas um caso de DFT sem DNM descrito na literatura, com a mutação p.A282V. ${ }^{263}$ A mutação p.A282V é possivelmente patogênica, e não foi encontrada em controles. No entanto, ela está localizada fora da região com 
repetições PXX, onde as outras mutações foram encontradas, e não há estudos funcionais comprovando sua patogenicidade.

Uma família com a mutação p.P497L foi recentemente descrita, com caracterização do quadro clínico em cinco gerações. ${ }^{267}$ Nessa família, o quadro se iniciava antes dos 10 anos de idade em homens e entre os 20-30 anos em mulheres. Em geral, disartria e perda do controle fino dos movimentos eram os sintomas iniciais. Posteriormente, os pacientes desenvolviam quadro caracterizado por tetraparesia espástica, por vezes acompanhada por distonia ou movimentos coreoatetóides, e progressivamente evoluíam para um quadro demencial com predomínio de sintomas comportamentais. A neuroimagem inicialmente era normal, mas com a progressão se observava comprometimento do córtex cerebral, substância negra, núcleo caudado e trato corticoespinhal. A sobrevida variou entre 4 a 17 anos. Apenas uma paciente dessa família desenvolveu um quadro característico de ELA aos 63 anos de idade e faleceu aos 67 anos, sem sinais de demência.

Neuropatologia. Estudos demonstraram inclusões imunorreativas a anticorpos contra ubiquilina 2 em neurônios motores espinais e no hipocampo. ${ }^{262}$ Além de ser imunorreativas a anticorpos contra ubiquitina e p62, as inclusões positivas para ubiquilina 2 parecem estar co-localizadas com TDP-43 e FUS. ${ }^{268}$ As inclusões positivas para ubiquilina 2 não são específicas para os casos com mutações neste gene, já que foram também encontradas em casos de ELA e DLFT-DNM sem mutações em UBQLN2.262

$\mathrm{Na}$ família com a mutação p.P497L, foram relatadas inclusões imunorreativas a anticorpos contra ubiquilina 2 no tronco encefálico e formações hipocampais, além de inclusões com marcação positiva para TDP-43. ${ }^{267}$

\subsection{Outros genes do espectro das DLFT-DNM}

Mutações em outros genes causadores de DNM também foram descritas com o fenótipo de vcDFT-DNM, em poucos casos, ou em relatos de casos isolados.

Mutações no gene da optineurina (OPTM) são conhecidas como causadoras de glaucoma de ângulo aberto, e mais recentemente, mutações em homozigose e heterozigose foram identificadas em casos de ELA. ${ }^{269}$ Mutações em OPTN também 
foram descritas em dois casos de vcDFT-DNM, com atrofia temporal e inclusões citoplasmáticas imunorreativas a anticorpos contra TDP-43.270,271 Assim como outras proteínas associadas a DLFT-DNM, a optineurina está envolvida nas vias de degradação de proteínas por autofagia. ${ }^{58}$ Variantes em OPTN também foram identificadas em estudos de associação genômica ampla (GWAS, de genome-wide association studies) como fator de risco para doença de Paget óssea. ${ }^{272,273}$ Isso é de interesse no contexto das proteinopatias multissistêmicas, que serão discutidas adiante.

O fenótipo de vcDFT-DNM também foi descrito em mutações de SOD1 (superóxido dismutase), ${ }^{274}$ DCTN1 (dinactina 1), ${ }^{275}$ ANG (angiogenina), ${ }^{276}$ SIGMAR1 (receptor intracelular não-opióde sigma 1), ${ }^{277}$, e DJ-1 (PARK 7). ${ }^{278}$ Mutações em SOD1 são a causa genética mais comum de ELA, mas são raramente associadas a sintomas cognitivos ou comportamentais. ${ }^{279}$ Mutações em DCTN1 são tipicamente associadas à síndrome de Perry, uma doença autossômica dominante caracterizada por parkinsonismo, hipoventilação, perda de peso e depressão. Variantes em DCTN1, e também em ANG, são consideradas fatores de risco para ELA.233,280 Mutações em $D J-1$ causam doença de Parkinson de início precoce, com um padrão de herança autossômico recessivo (PARK 7). ${ }^{278}$ Mutações em SIGMA1R foram inicialmente descritas em casos de ELA juvenil. ${ }^{277}$

\subsubsection{Genes associados às Proteinopatias Multissistêmicas}

Mutações no gene VCP foram descobertas em 2004 como causadoras de um fenótipo complexo, que inicialmente incluía a miopatia com corpúsculos de inclusão, a doença de Paget óssea e a vcDFT e por isso era comumente descrita com o acrônimo IBMPFD (do inglês inclusion $\underline{b}$ ody $\underline{\text { myositis, }}$ Paget's disease of the bone and frontotemporal dementia). ${ }^{281} \mathrm{Em}$ 2010, um estudo multicêntrico que usou sequenciamento de exoma descobriu que mutações em $V C P$ também podem causar ELA familial, ampliando assim o fenótipo associado a mutações de $V C P .{ }^{282}$ Posteriormente, verificou-se que essas famílias ocasionalmente podem apresentar manifestações sistêmicas, como cardíacas, hepáticas, de sistema nervoso periférico, entre outras, de modo que o acrônimo inicialmente empregado não parecia mais 
adequado. ${ }^{283,284}$ Assim, Benatar et al. propuseram que este grupo de doenças seja nomeado de "proteinopatias multissistêmicas" 59

A miopatia com corpúsculos de inclusão se manifesta inicialmente com fraqueza de músculos da cintura escapular e pélvica. A fraqueza se apresenta de maneira lentamente progressiva, e os pacientes levam em média de 10 a 15 anos para ficarem dependentes de cadeira de rodas. Os reflexos osteotendíneos são tipicamente abolidos ou hipoativos, e a creatina quinase (CPK) é normal ou levemente aumentada. A biópsia muscular mostra sinais de miopatia, vacúolos marginados, e inclusões imunocoradas com anticorpos contra ubiquitina, p62 e TDP-43. ${ }^{284}$

A doença de Paget óssea é caracterizada por remodelamento ósseo focal, com aumento da atividade osteoclástica levando a lesões líticas nos ossos (caracteristicamente no crânio, vértebras e/ou pelve), e espessamento ósseo. Indivíduos com a doença de Paget óssea podem ser assintomáticos, ou desenvolver sintomas como dores ósseas, fraturas patológicas ou osteoartrite. A fosfatase alcalina sérica normalmente está elevada. Tanto formas esporádicas quanto familiais da doença de Paget óssea já foram descritas, e a forma familial se inicia mais precocemente e é mais grave do que a forma esporádica. ${ }^{285}$ A doença é tratável, com bisfosfonados, e por isso é de grande importância a identificação de indivíduos em risco.

Mutações em VCP são a causa mais frequente da proteinopatia multissistêmica, mas mutações nos genes HNRNPA1 e HNRNPA2B1 também foram identificados. ${ }^{286}$. Mutações no gene SQSTM1 ainda não foram associadas a miopatia com corpúsculos de inclusão, mas já foram encontradas nos outros fenótipos da síndrome. ${ }^{287}$ Outros genes devem ser identificados no futuro, uma vez que mutações nesses quatro genes não explicam todos os casos de proteinopatia multissistêmica familial. ${ }^{288}$

\subsection{Gene VCP}

Gene e proteína. O gene VCP (valosin-containing protein) está localizado no cromossomo $9 p$ (9p13.3). A proteína que contem valosina é uma proteína $A A A+$ (ATPase associada com uma variedade de atividades celulares), que participa de 
múltiplos processos celulares, como degradação de proteínas ubiquitinadas pelo sistema ubiquitina-proteassoma e por autofagia. ${ }^{284}$

Mutações patogênicas. Atualmente, são conhecidas 18 mutações missense do gene em 48 famílias. ${ }^{77}$ As mutações em VCP parecem afetar as vias de degradação de proteínas, o que deve levar a neurodegeneração. ${ }^{284}$

A transmissão ocorre em padrão de herança autossômico dominante, com penetrância variável de acordo com o fenótipo (cerca de 30\% dos pacientes desenvolvem vcDFT, $85-90 \%$ desenvolvem miopatia com corpúsculos de inclusão e 45-50\% apresentam doença de Paget óssea). ${ }^{73,289,290}$

Aspectos clínicos. Mutações em VCP são encontradas em menos de $2 \%$ dos casos de DFT, e são responsáveis por $50-75 \%$ dos casos de proteinopatia sistêmica familial. ${ }^{48,56,85,287-289} \mathrm{O}$ início dos sintomas da miopatia (média 43 anos) e doença de Paget (média 42 anos) geralmente ocorrem mais precocemente do que o da DFT (média 55 anos). ${ }^{291}$ Indivíduos com mutação podem desenvolver os três fenótipos (12\%), uma combinação de dois dos fenótipos (50\%), ou apenas um dos fenótipos $(38 \%) .{ }^{291}$ Apenas $3 \%$ desenvolvem DFT isoladamente, mas já foi descrita uma família que apresentou apenas o fenótipo cognitivo. ${ }^{289,291}$

As manifestações neuropsiquiátricas são compatíveis com vcDFT na grande maioria dos casos, mas há relatos de vsAPP e demência do tipo Alzheimer. ${ }^{281,283} \mathrm{~A}$ duração da doença é em média de 19 anos após o início da miopatia ou doença de Paget, mas apenas de 6 anos em média após o início da demência. ${ }^{283}$

Recentemente uma mutação (p.R93C) foi identificada em um paciente brasileiro que apresentava miopatia, doença de Paget e vcDFT ${ }^{65}$.

Mutações em VCP foram encontradas em cerca de $2 \%$ dos casos familiais de ELA, e cerca de $9 \%$ dos indivíduos com mutações neste gene desenvolvem ELA. ${ }^{282,283,292}$

Neuropatologia. O achado neuropatológico em mutações de VCP é de DLFTTDP tipo D (Tabela 5). ${ }^{44}$

\subsection{Genes HNRNPA2B1 e HNRNPA1}


Gene e proteína. Os genes HNRNPA2B1 e HNRNPA1 (ribonucleoproteínas nucleares heterogêneas $A 2 / B 1$ e $A 1$, respectivamente) codificam ribonucleoproteínas que participam do metabolismo de RNA, e interagem com outras ribonucleoproteínas, como a TDP-43. ${ }^{59,286,288} \mathrm{O}$ gene HNRNPA2B1 está localizado na banda citogenética 7p15 e o gene HNRNPA1, na banda citogenética 12q13.1.

Mutações patogênicas. As mutações descritas até 0 momento estão localizadas nos domínios príon-like das proteínas, e facilitam a fibrilização e incorporação em grânulos de estresse das ribonucleoproteínas, além de induzir a formação de inclusões citoplasmáticas patológicas em modelos animais. ${ }^{286}$

Aspectos clínicos. Mutações nestes genes foram relatadas por dois grupos e são causas raras de proteinopatia multissistêmica familial (0-12\%), e de ELA familial e esporádica. ${ }^{59,286}$ Mutações em HNRNPA2B1 e HNRNPA1 não foram encontradas em casuísticas francesas e dinamarquesas de DFT e ELA, ou em casos de proteinopatia multissistêmica na França. ${ }^{288,293}$

Neuropatologia. Não há relatos com os achados neuropatológicos nestas mutações até o momento, mas um estudo encontrou inclusões citoplasmáticas imunorreativas a TDP-43, hnRNPA2/B1, e hnRNPA1 em biópsia muscular de pacientes com a mutação. ${ }^{286}$

\subsection{Gene SQSTM1}

Gene e proteína. O gene SQSTM1 (sequestossoma 1) codifica a proteína p62, que participa da degradação de proteínas ubiquitinadas por autofagia, e também é implicada na diferenciação celular, apoptose e respostas imunes. ${ }^{294,295} \mathrm{O}$ gene fica na banda citogenética $5 q 35$.

Mutações patogênicas. A maior parte das mutações identificadas se localiza no domínio associado a ubiquitina (UBA, do inglês ubiquitin-associated) da proteína. Mas mutações em outras regiões do gene também foram descritas, e incluem mutações missense (maior parte), nonsense e deleções. ${ }^{296}$ Acredita-se que as mutações afetam a ligação da proteína p62, e consequentemente, a degradação de proteínas, como a TDP-43. ${ }^{294,295}$ 
Aspectos clínicos. O fenótipo mais frequentemente observado em mutações de SQSTM1 é a doença de Paget óssea, e mutações são encontradas em 25-50\% dos casos de doença de Paget familial e 5-10\% dos casos esporádicos. ${ }^{285}$ Enquanto que este gene foi inicialmente associado a doença de Paget em 2002, apenas a partir de 2011 que casos de ELA esporádica e familial, vcDFT familial e DFT-DNM familial começaram a ser identificados em mutações de SQSTM1.287,297 Já foram descritas famílias com os fenótipos de vcDFT, doença de Paget, e/ou ELA, mas vcDFT e ELA também foram observados em famílias sem história de doença de Paget. ${ }^{294,297}$

Mutações em SQSTM1 foram encontradas em 0,9-3\% dos casos de DFT e ELA (familial e esporádica), e em menos de $5 \%$ dos casos familiais de proteinopatia multissistêmica. ${ }^{287,294-297} \mathrm{O}$ início dos sintomas na DFT variou entre 48 e 73 anos. ${ }^{287,294}$

Mutações em SQSTM1 foram identificadas em raros pacientes diagnosticados com vnfAPP, vsAPP, PSP e SCB, mas a patogenicidade dessas mutações ainda precisa ser confirmada. ${ }^{296,298}$

Neuropatologia. Inclusões imunorreativas a p62, TDP-43 e em alguns casos a TDP-43 fosforilada, em neurônios e células da glia foram descritas em pacientes com mutações em SQSTM1.295,296

\subsubsection{Gene CHMP2B}

Gene e proteína. O gene CHMP2B (charged multivesicular body protein 2B) está localizado no cromossomo 3p11.2. A proteína CHMP2B faz parte do complexo ESCRT-III (endosomal sorting complex required for transport-III), que participa de vias de degradação de proteínas associadas a endossomas e lisossomas. ${ }^{299}$.

Mutações patogênicas. Mutações nonsense em $C H M P 2 B$ são causas genéticas raras de DFT, e foram descritas em famílias dinamarquesas e belgas com padrão de herança autossômico dominante. ${ }^{299-301}$ As mutações levam a formação de proteínas truncadas no carboxi-terminal. Até o momento foram descritas quatro mutações em cinco famílias. ${ }^{77}$

Aspectos clínicos. A idade média de início da vcDFT causada por mutações nonsense em CHMP2B é de 58 anos, variando entre 48 e 67 anos. A duração da doença é na média de 10 anos, mas pode variar entre 3 e 21 anos. ${ }^{300}$ 
Mutações missense no gene foram descritas em pacientes com DNM (particularmente com atrofia muscular primária), DFT-DNM, e casos isolados de vsAPP e SCB. ${ }^{299,301-304}$ No entanto, deve-se ressaltar que a patogenicidade dessas mutações não foi ainda comprovada de modo inequívoco e a maior parte das mutações missense foi descrita em casos esporádicos.

Neuropatologia. Gera interesse o fato de o achado neuropatológico ser de DLFT-U, ou seja, as inclusões são imunocoradas com anticorpos contra ubiquitina e p62, mas não contra tau, TDP-43 ou FUS. Isso indica que deve haver nesses casos outra forma de proteinopatia ainda não descrita. ${ }^{40}$ Mutações em $C H M P 2 B$ representam a maior parte dos casos de DLFT-U, e apenas raros casos esporádicos de DLFT-U foram descritos. ${ }^{305}$

\subsubsection{Genes associados às formas poligênicas da DLFT}

Estudos de associação genética nas formas esporádicas de DFT são dificultados pela heterogeneidade neuropatológica observadas nas síndromes clínicas, e pela falta de biomarcadores que permitam predizer o diagnóstico neuropatológico com acurácia aceitável ainda durante a vida. É de se imaginar que cada subtipo neuropatológico da DLFT esteja associado a diferentes variações genéticas, em diferentes genes, e por isso o poder de estudos de associação realizados apenas com base em fenótipos clínicos era muito reduzido. Uma das maneiras encontradas para de se superar essa limitação foi a inclusão apenas de casos com diagnóstico neuropatológico confirmado. Com isso, alguns estudos conseguiram identificar variantes de risco, apesar da redução do número de casos disponíveis para análise.

Para lidar com a questão da heterogeneidade neuropatológica, o primeiro GWAS em DLFT incluiu apenas casos de DLFT-TDP, e foi publicado em 2010. ${ }^{306}$ Esse estudo incluiu 515 casos de DLFT-TDP, e encontrou associação significativa com SNPs no gene TMEM106B (como o rs1990622 com OR=0,61 e $p=1,08 \times 10^{-11}$ em relação ao alelo menor $\mathrm{C}$ ), localizado em $7 \mathrm{p} 21$. A associação foi ainda mais significativa em uma análise apenas com indivíduos com mutações em GRN. A associação com variantes em TMEM106B foi replicada em uma casuística belga de 
DFT. ${ }^{307}$ Estudos posteriores indicaram que rs1990622 estava em alto desequilíbrio de ligação com rs3173615 ( $\mathrm{r} 2=0,98)$, que corresponde a uma mutação missense (p.T185S). ${ }^{62}$

O gene TMEM106B codifica a proteína transmembrana 106B, uma glicoproteína localizada predominantemente na membrana de endossomos tardios e lisossomos, local onde ela pode interagir com GRN. ${ }^{308-310} \mathrm{~A}$ isoforma protetora da proteína é a S185, que foi associada a níveis mais baixos de TMEM106B do que a isoforma T185, o que é compatível com o achado de aumento na expressão de TMEM106B em cérebros de indivíduos com DLFT-TDP encontrado em alguns (mas não todos) estudos. $62,306,311$ Alguns estudos demonstraram que o aumento da expressão de TMEM106B está relacionada a aumento de progranulina, mas ainda não está claro como isso leva a um aumento de risco de DLFT-TDP. ${ }^{311}$

Variantes em TMEM106B também parecem influenciar a apresentação de mutações nas formas monogênicas de DLFT-TDP. Homozigose do alelo menor de rs1990622 (genótipo CC) foi associado a redução de penetrância em indivíduos com mutação em $G R N(\mathrm{OR}=0,12, \mathrm{p}=0,09),{ }^{312}$ enquanto que o alelo maior do mesmo SNP foi associado a idade mais precoce de início de sintomas. ${ }^{313} \mathrm{Em}$ indivíduos com expansões em C9orf72, um estudo mostrou que a homozigose do alelo menor de rs3173615 (genótipo GG, equivalente a TMEM106B p.T185S) conferia um efeito protetor para DFT $(\mathrm{OR}=0,33)$ ou DFT-DNM $(\mathrm{OR}=0,38)$, mas não para DNM isoladamente $(\mathrm{OR}=0,85) .{ }^{185}$ Outro estudo associou o alelo maior (T) de rs1990622 com idade de início dos sintomas e de óbito mais tardias, em pacientes com DFT com a expansão em C9orf72. ${ }^{314}$

Em 2014 foi publicado um GWAS em DFT com a colaboração de 44 grupos de pesquisa. ${ }^{61}$ Todos os participantes tinham ascendência européia, e foram analisadas amostras de 3526 pacientes com DFT (2417 com vcDFT, 576 com vsAPP, 582 com vnfAPP, 344 com DFT-DNM, e 221 com DFT não especificada) e de 9402 controles saudáveis. Na análise combinada das fases de descoberta e replicação com a amostra de DFT inteira, encontrou-se associação estatisticamente significativa com 3 SNPs (rs9268877, rs9268856 e rs1980493) localizados em 6p21.3. Esse lócus contém genes do sistema HLA, como HLA-DRA e HLA-DRB5, o que indica que o sistema imune possa ter papel na patogênese da DFT. A análise do subgrupo de vcDFT encontrou uma associação sugestiva com o SNP rs302668, localizado no gene 
RAB38 (RAB 38, membro da família de oncogenes RAS) e próximo ao gene CTSC (catepsina C). Esses genes (RAB38 e CTSC) codificam proteínas que participam da biologia dos lisossomos, assim como outras proteínas codificadas por genes que estão associados a DFT, como GRN e TMEM106B.

\subsection{Biomarcadores no sangue e líquido cefalorraquidiano na DLFT}

A procura de biomarcadores no sangue ou líquido cefalorraquidiano (LCR) para DLFT tem se baseado na pesquisa das proteínas anormais encontradas na análise neuropatológica (como tau e TDP-43) e em estudos genéticos (como é o caso da progranulina). O uso de biomarcadores em sangue ou LCR para diagnóstico em DLFT ainda é bastante limitado. Um dos principais motivos é a heterogeneidade das doenças que fazem parte do espectro clínico das DLFTs e seus substratos neuropatológicos. ${ }^{315}$ Uma exceção a essa limitação é a dosagem no plasma (ou no LCR) de progranulina que é marcadora da presença de mutações patogênicas em GRN e tem o potencial de ser utilizada em ensaios clínicos futuros para avaliar a resposta ao tratamento nesse grupo. ${ }^{316}$

\subsubsection{Tau}

A pesquisa de tau total e tau hiperfosforilada (fosfo-tau) no LCR de pacientes com DLFT resultou em achados divergentes nos diversos estudos. Estudos com tau demonstraram níveis menores, ${ }^{317}$ similares, ${ }^{318}$ ou maiores ${ }^{319}$ de tau em pacientes com DFT em relação a controles. Cabe salientar que o estudo de Rosso et al. incluiu pacientes com mutações no gene MAPT. ${ }^{318} \mathrm{O}$ uso conjunto da dosagem de tau e amilóide $\beta_{1-42}$ no LCR (ou razão tau/Aß42) parece ser particularmente útil para diferenciar DA e vcDFT, mas não para diferenciar DFT de controles. Em diversos estudos publicados, para o diagnóstico diferencial de DA e DFT, a sensibilidade da razão tau/A $A 42$ variou de $79-100 \%$, e sensibilidade de $80-96 \% .{ }^{315}$

Um estudo recente, validado em duas casuísticas, relatou que a razão $p$ tau181/t-tau (tau fosforilada no resíduo 181 sobre tau total) no LCR menor que 0,37 era 
capaz de diferenciar DLFT-TDP de DLFT-tau, DA e idosos saudáveis com sensibilidade e especificidade de $82 \%$. ${ }^{320}$ Apesar de os autores não apresentarem uma explicação fisiopatológica para esse achado, os resultados de outro grupo foram concordantes, dando mais evidências que indicam que a razão p-tau $181 / \mathrm{t}$-tau pode ser um biomarcador viável para DLFT-TDP. 321

\subsubsection{TDP-43}

Há poucos estudos na literatura utilizando TDP-43 como biomarcador. Steinacker et al. observaram níveis mais altos de TDP-43 no LCR de pacientes com DFT em relação a controles, porém com significativa sobreposição de valores. ${ }^{322}$ Foulds et al. encontraram níveis aumentados de TDP-43 no plasma de $46 \%$ dos pacientes com DLFT, porém em estudo posterior não encontraram relação significativa entre níveis de TDP-43 no plasma e presença de TDP-43 como achado neuropatológico. 323,324

Outro estudo encontrou níveis aumentados de TDP-43 fosforilada no sangue e LCR de pacientes com mutações em C9orf72 $(n=10)$ e GRN $(n=5)$, em relação a pacientes com DFT sem mutações $(n=20) .{ }^{325}$ No entanto, por ser um estudo pequeno, os resultados precisam ser replicados em casuísticas maiores.

\subsubsection{Progranulina}

Em pacientes com mutações patogênicas com perda de função do gene $G R N$, os níveis de progranulina no plasma e no LCR estão significativamente reduzido (em cerca de 75\%), em comparação com controles, ou pacientes com DFT, ou com DA de início precoce (sem mutação de $G R M$ ), corroborando a hipótese de haploinsuficiência como mecanismo de doença nesses casos. ${ }^{152,153,155}$ Indivíduos pré-sintomáticos apresentam níveis similares aos indivíduos sintomáticos com mutação em GRN. ${ }^{152,153}$ Através da dosagem de progranulina por ELISA, Finch et al. estabeleceram valor de corte de $112 \mathrm{ng} / \mathrm{ml}^{152} \mathrm{Em}$ estudo mais recente, Ghidoni et al. encontraram 
sensibilidade de $95,8 \%$ e especificidade de $99,6 \%$ ao utilizar um valor de corte de $61,55 \mathrm{ng} / \mathrm{ml} .{ }^{154}$

Diversos fatores também influenciam os níveis de progranulina no plasma e líquido cefalorraquidiano, como idade, sexo, fatores sistêmicos, e outros fatores genéticos. Em um estudo com 345 indivíduos cognitivamente normais, com comprometimento cognitivo leve, ou demência do tipo Alzheimer, com idades entre 70 e 89 anos, Nicholson et al. observaram aumento dos níveis de progranulina de cerca de $3 \%$ no plasma e $2 \%$ no LCR, a cada 5 anos de aumento na idade. ${ }^{326}$ Nesse mesmo estudo, os níveis de progranulina no plasma em homens foram $7 \%$ mais baixos do que em mulheres, enquanto que no LCR, ocorria o inverso, e os homens apresentaram níveis $5 \%$ mais altos do que nas mulheres.

Aumento dos níveis de progranulina no soro ou plasma também já foi relatado em indivíduos com diabete melito tipo 2, na obesidade, durante a gestação, e na doença renal crônica. ${ }^{327-329}$ Além disso, alguns estudos mostraram associação entre os níveis de progranulina e o índice de massa corpórea, glicemia de jejum, e resistência à insulina. ${ }^{330}$ Refletindo o papel da progranulina em processos inflamatórios, níveis aumentados de progranulina foram encontrados em pacientes com lúpus eritematoso sistêmico, com correlação entre os níveis de progranulina e marcadores de atividade da doença. ${ }^{331}$ Estudos com câncer epilelial de ovário têm sugerido que os níveis de progranulina no plasma podem ser marcadores de prognóstico, apesar de não serem adequados como método diagnóstico. ${ }^{332}$

Em relação a fatores genéticos que modulam os níveis de progranulina, um estudo de associação genômica ampla (GWAS) identificou o polimorfismo de nucleotídeo único (SNP, de single nucleotide polymorphism) rs646776, localizado próximo ao gene da sortilina (SORT1), como associado aos níveis plasmáticos de progranulina. ${ }^{333}$ No entanto, não se encontrou associação entre o SNP e níveis de RNA mensageiro de SORT1 no cérebro, sugerindo que esse SNP não deve influenciar os níveis de progranulina no cérebro. Posteriormente, outro estudo do mesmo grupo não encontrou associação entre rs646776 e os níveis de progranulina no LCR. ${ }^{326}$ Esses dados indicam que existem fatores que controlam os níveis de progranulina que são específicos de cada tecido, e que os níveis de progranulina no plasma não necessariamente se correlacionam com os níveis no tecido cerebral. 
O SNP rs5848, localizado em GRN e anteriormente mencionado como fator de risco para DLFT-TDP, também influencia os níveis de progranulina. ${ }^{334}$ Cada alelo menor (T) foi associado a uma redução de 5\% nos níveis de progranulina no plasma, e de $8 \%$ nos níveis do líquido cefalorraquidiano. ${ }^{326}$

O SNP rs1990622, localizado no gene TMEM106B, também foi associado em um estudo aos níveis de progranulina no plasma e à expressão de RNA mensageiro de progranulina no cérebro. ${ }^{312,313}$ Isso poderia indicar um mecanismo genético que modularia a apresentação clínica das mutações de GRN como penetrância e idade de início dos sintomas. No entanto, esse achado não foi replicado por outros grupos. ${ }^{62,307}$ De qualquer modo, como já mencionado antes, variantes no gene TMEM106B têm se mostrado como um fator de risco importante para DLFT-TDP. ${ }^{62}$

\subsubsection{Proteínas com repetições de dipeptídeos}

Um grupo recentemente demonstrou que proteínas com repetições de dipeptídeos podem ser mensuradas no LCR de pacientes com expansões de hexanucleotídeos no gene C9orf72. Eles encontraram níveis mais elevados do polipeptídeo poliGP em um grupo de 14 pacientes com ELA que tinham a mutação do que em um grupo de 25 pacientes com ELA sem a mutação e um grupo de cinco indivíduos saudáveis. ${ }^{335}$ A mensuração destas proteínas ainda não foi realizada em pacientes com DFT com a expansão.

\subsubsection{Neurofilamentos de cadeia leve}

Os neurofilamentos fazem parte do citoesqueleto de neurônios, e são biomarcadores de morte neuronal e perda axonal. ${ }^{336}$ Os neurofilamentos de cadeia leve são uma das três subunidades dos neurofilamentos, e recentemente têm sido investigados como biomarcadores em DFT. Os estudos publicados demonstraram níveis aumentados de neurofilamentos de cadeia leve no LCR de pacientes com DFT em relação a controles e pacientes com DA, apesar de que a diferença entre DA e DFT não é achado consistente em todos os estudos. ${ }^{336-338}$ Dentre as apresentações 
de DFT, dois estudos encontraram níveis mais elevados de neurofilamentos de cadeia leve em pacientes com vcDFT e vsAPP. Os achados sugerem que os neurofilamentos de cadeia leve devem estar mais aumentados na patologia DLFT-TDP do que na patologia DLFT-tau, mas isso ainda requer estudos comprobatórios. ${ }^{336,337}$

Os resultados de um estudo recente indicam que os níveis de neurofilamentos de cadeia leve estejam correlacionados com a gravidade da DFT. Scherling et al. encontraram correlação positiva entre os níveis de neurofilamentos de cadeia leve no líquido cefalorraquidiano de pacientes com DFT e o escore soma de boxes do Clinical Dementia Rating scale, e correlação negativa entre os níveis de neurofilamentos de cadeia curta e os volumes de substância branca e cinzenta nos lobos temporais e frontais. ${ }^{337}$ 


\section{OBJETIVOS}

2.1. Objetivos principais

2.1.1. Determinar a frequência e tipo de mutações dos genes da progranulina (GRM) e da proteína tau (MAPT) em casuística brasileira de portadores de DFT;

2.1.2. Determinar se a dosagem plasmática de progranulina é marcador da presença de mutações patogênicas do gene da progranulina em casuística brasileira de portadores de DFT e estabelecer o ponto de corte nesta população;

\subsection{Objetivos secundários}

2.2.1. Obter correlações clínico-genéticas em portadores de mutações patogênicas dos genes GRN e MAPT, em casuística brasileira.

2.2.2. Desenvolver técnica de pesquisa de mutações dos genes GRN e MAPT, assim como técnica de dosagem plasmática de progranulina. 


\section{CASUÍSTICA E MÉTODOS}

\subsection{Casuística}

Foram incluídos pacientes com diagnóstico clínico de DFT atendidos no ambulatório do Neurologia do Hospital das Clínicas da Faculdade de Medicina da Universidade de São Paulo (HCFMUSP), por membros do Grupo de Neurologia Cognitiva e do Comportamento (GNCC), ou em acompanhamento no Centro de Referência em Distúrbios Cognitivos (CEREDIC) do mesmo hospital. Os critérios diagnósticos utilizados para inclusão foram os de vcDFT propostos por Rascovsky et al., e os de vsAPP e vnfAPP propostos por Gorno-Tempini et al. (Tabelas 1, 2, 3 e 4).2,3 Dados clínicos e demográficos foram coletados a partir de informações de prontuário e, quando necessário, complementados por informações obtidas dos pacientes e seus acompanhantes no momento da coleta de material genético.

Cônjuges de pacientes, acompanhantes não relacionados de pacientes, e funcionários/voluntários do ambulatório de neurologia do HCFMUSP que não apresentavam evidências de afecção neurológica ou psiquiátrica, ou de doença sistêmica descompensada, foram convidados para participar do estudo como indivíduos do grupo controle. Foram selecionados para o grupo controle os indivíduos que obtiveram escores satisfatórios no questionário de atividades funcionais (QAF) de Pfeffer ${ }^{339}$ e Mini-Exame do Estado Mental (MEEM). ${ }^{340,341}$ Foram adotadas as seguintes notas de corte: menor ou igual a dois pontos no QAF, e no MEEM, pontuação maior ou igual a 18 para analfabetos, maior ou igual a 24 para indivíduos com escolaridade de 1 a 7 anos, e maior ou igual a 26 para indivíduos com escolaridade maior ou igual a 8 anos. ${ }^{341}$

Os pacientes (ou seus responsáveis legais) assinaram termo de consentimento livre e esclarecido antes de participar do estudo. Este estudo foi aprovado pela comissão de ética do HCFMUSP (CAPPesq 0252/10), sendo parte do estudo intitulado "Análise da presença e tipo de mutação dos genes da progranulina e da TDP-43 em pacientes com Degeneração Lobar Frontotemporal e com Doença de Alzheimer alelo tipo específico". Este estudo foi financiado pela Fundação de Amparo à Pesquisa do Estado de São Paulo (processo 2013/01758-4). 


\subsection{Metodologia laboratorial}

\subsubsection{Sequenciamento}

Dezesseis mililitros de sangue obtidos através de punção de veia periférica foram colhidos de cada paciente incluído no estudo. O DNA leucocitário foi extraído seguindo protocolo modificado de Miller et al. ${ }^{342}$

Para extração de DNA, as amostras de sangue foram colocadas em tubo Falcon de $50 \mathrm{ml}$, e misturadas a uma solução de lise de células (composta por $\mathrm{NH}_{4} \mathrm{Cl}$, $\mathrm{HCO}_{3}$, e EDTA 0,2M) 1x até completar o volume de $45 \mathrm{ml}$. Então, os tubos foram colocados no gelo por 30 minutos, e posteriormente centrifugados a 2000rpm por 25 minutos, com a centrífuga a uma temperatura de $8^{\circ} \mathrm{C}$. O sobrenadante então foi desprezado e o sedimento restante (pellet) ressuspendido em $30 \mathrm{ml}$ da solução de lise de células. Depois, o tubo foi novamente centrifugado a 2000rpm, por dez minutos. $O$ sobrenadante foi também descartado, e o pellet misturado com $3 \mathrm{ml}$ de solução de lise de núcleos (com Tris-HCL, NaCl, e EDTA 0,2M)

A seguir, $0,7 \mathrm{mg}$ de proteinase $\mathrm{K}$ e $300 \mu \mathrm{l}$ de SDS (dodecil sulfato de sódio) a $10 \%$ foram acrescentados a cada tubo Falcon. Os tubos foram agitados, e posteriormente deixados em estufa a $37^{\circ} \mathrm{C}$ até o dia seguinte.

No segundo dia de extração, $1 \mathrm{ml}$ de $\mathrm{NaCl} 6 \mathrm{M}$ foi adicionado a cada tubo, que foi então agitado vigorosamente e centrifugado a 3000rpm por 30 minutos. O sobrenadante foi descartado, e os tubos Falcon foram novamente centrifugados a 3000rpm, por 20 minutos. O conteúdo dos tubos Falcon foi então transferido para frascos de vidro, onde ocorria a precipitação do DNA. Em cada tubo de vidro, acrescentava-se etanol absoluto gelado até completar $25 \mathrm{ml}$. O DNA foi então "pescado" do tubo de vidro com um capilar, lavado com etanol $70 \%$, e colocado em tubo transparente. Esperava-se o etanol evaporar, e então o DNA foi ressuspendido em 300-600 $\mu$ l de solução TE (Tris 1,0M e EDTA 0,5M). Os tubos foram então colocados em banho seco a $65^{\circ} \mathrm{C}$ por 40 minutos, e posteriormente armazenados a $4^{\circ} \mathrm{C}$ 
Após a extração de DNA, as amostras foram quantificadas em espectofotômetro (NanoDrop 1000, Thermo Scientific ${ }^{\circledR}$ ) e diluídas em água tratada com DEPC e autoclavada, para a que a concentração final fosse de 50ng/ $\mu$.

Para reação de PCR (polymerase chain reaction) foram utilizados os seguintes reagentes: $12,5 \mu$ de PCR MasterMix (Fermentas/Thermo Scientific ${ }^{\circledR}$ ), 4,5 $\mu$ le água DEPC autoclavada, $2 \mu$ de cada sequência iniciadora (primers forward e reverse; vide Tabelas 6 e 7), e $4 \mu$ de DNA diluído a 50ng/ $\mu$ l.

Para a amplificação dos éxons 2, 3, 4, 7, 8, 9, 10, 11, 12 e 13 do gene GRN, o parâmetros utilizados no termociclador (Eppendorf Mastercycler pro®) foram os de um protocolo touchdown descrito por Van Deerlin e cols.: $:^{141} 95^{\circ} \mathrm{C}$ por 10 minutos, seguidos por 14 ciclos de $95^{\circ} \mathrm{C}$ (por 30 segundos), $58^{\circ} \mathrm{C}$ com redução de $0,5^{\circ} \mathrm{C}$ a cada ciclo (por 30 segundos), $72^{\circ} \mathrm{C}$ (por 60 segundos), e posteriormente seguidos por 20 ciclos de $95^{\circ} \mathrm{C}$ (30 segundos), $51^{\circ} \mathrm{C}$ (30 segundos) e $72^{\circ} \mathrm{C}$ (60 segundos), com extensão final por 5 minutos a $72^{\circ} \mathrm{C}$. O protocolo para o amplicon que incluía os éxons 5 e 6 era diferente apenas na denaturação inicial, feita em 2 minutos.

Para a amplificação dos éxons 1, 9, 10, 11, 12 e 13 do gene MAPT, os parâmetros utilizados no termociclador foram os seguintes: $94^{\circ} \mathrm{C}$ por 12 minutos, seguidos por 14 ciclos de $94^{\circ} \mathrm{C}$ (por 30 segundos), $60^{\circ} \mathrm{C}$ com redução de $0,5^{\circ} \mathrm{C}$ a cada ciclo (por 30 segundos), $72^{\circ} \mathrm{C}$ (por 30 segundos), e posteriormente seguidos por 21 ciclos de $94^{\circ} \mathrm{C}$ (30 segundos), $53^{\circ} \mathrm{C}$ (30 segundos) e $72^{\circ} \mathrm{C}$ (30 segundos), com extensão final por 10 minutos a $72^{\circ} \mathrm{C}$.

Tabela 6 - Sequências iniciadoras (primers) utilizadas para amplificação dos éxons 2 a 13 de $G R N^{141}$

\begin{tabular}{|c|c|c|c|c|}
\hline Exon & Orientação & Primer & $\mathrm{T}_{\mathrm{M}}$ & Tamanho (pb) \\
\hline \multirow{2}{*}{ Éxon 2} & Forward & GGGCTAGGGTACTGAGTGAC & $56,3^{\circ} \mathrm{C}$ & \multirow{2}{*}{368} \\
\hline & Reverse & AGTGTTGTGGGCCATTTG & $57,9^{\circ} \mathrm{C}$ & \\
\hline \multirow{2}{*}{ Éxon 3} & Forward & TGCCCAGATGGTCAGTTC & $58^{\circ} \mathrm{C}$ & \multirow{2}{*}{537} \\
\hline & Reverse & GCTGCACCTGATCTTTGG & $57,8^{\circ} \mathrm{C}$ & \\
\hline \multirow{2}{*}{ Éxon 4} & Forward & GGCCACTCCTGCATCTTTAC & $59,7^{\circ} \mathrm{C}$ & \multirow{2}{*}{369} \\
\hline & Reverse & TGAATGAGGGCACAAGGG & $60,6^{\circ} \mathrm{C}$ & \\
\hline \multirow{2}{*}{$\begin{array}{l}\text { Éxons } 5 \\
\& 6\end{array}$} & Forward & TTAGTGTCACCCTCAAACC & $53,3^{\circ} \mathrm{C}$ & \multirow{2}{*}{587} \\
\hline & Reverse & ACTGGAAGAGGAGCAAAC & $52,5^{\circ} \mathrm{C}$ & \\
\hline \multirow{2}{*}{ Éxon 7} & Forward & GGGCCTCATTGACTCCAAGTGTA & $64,6^{\circ} \mathrm{C}$ & \multirow{2}{*}{401} \\
\hline & Reverse & GGTCTTTGTCACTTCCAGGCTCA & $65^{\circ} \mathrm{C}$ & \\
\hline
\end{tabular}




\begin{tabular}{|c|c|c|c|c|}
\hline \multirow{2}{*}{ Éxon 8} & Forward & TCCCTGTGTGCTACTGAG & $52,7^{\circ} \mathrm{C}$ & \multirow{2}{*}{373} \\
\hline & Reverse & AAGCAGAGAGGACAGGTC & $52,4^{\circ} \mathrm{C}$ & \\
\hline \multirow{2}{*}{ Éxon 9} & Forward & TACССТССАТСТTСАACAC & $53,2^{\circ} \mathrm{C}$ & \multirow{2}{*}{309} \\
\hline & Reverse & TCACAGCACACAGCCTAG & $54^{\circ} \mathrm{C}$ & \\
\hline \multirow{2}{*}{ Éxon 10} & Forward & ATACCTGCTGCCGTCTAC & $53,6^{\circ} \mathrm{C}$ & \multirow{2}{*}{457} \\
\hline & Reverse & GAGGGCAGAAAGCAATAG & $53,4^{\circ} \mathrm{C}$ & \\
\hline \multirow{2}{*}{ Éxon 11} & Forward & TGTCCAATCCCAGAGGTATATG & $58,8^{\circ} \mathrm{C}$ & \multirow{2}{*}{616} \\
\hline & Reverse & ACGTTGCAGGTGTAGCCAG & $59,9^{\circ} \mathrm{C}$ & \\
\hline \multirow{2}{*}{ Éxon 12} & Forward & TGGACTGGAGAAGATGCC & $57,1^{\circ} \mathrm{C}$ & \multirow{2}{*}{574} \\
\hline & Reverse & CGATCAGCACAACAGACG & $57,3^{\circ} \mathrm{C}$ & \\
\hline \multirow{2}{*}{ Éxon 13} & Forward & CATGATAACCAGACCTGC & $51,9^{\circ} \mathrm{C}$ & \multirow{2}{*}{387} \\
\hline & Reverse & AGGGAGAATTTGGTTAGG & $51,6^{\circ} \mathrm{C}$ & \\
\hline
\end{tabular}

Tabela 7 - Sequências iniciadoras (primers) utilizadas para amplificação dos éxons 1,9 a 13 de MAPT 82

\begin{tabular}{lllcc}
\hline Éxon & Orientação & Primer & TM & $\begin{array}{c}\text { Tamanho } \\
(\mathbf{p b})\end{array}$ \\
\hline Éxon 1 & Forward & GCCAACTGTTAGAGAGGGTAGC & $59,4^{\circ} \mathrm{C}$ & 469 \\
& Reverse & GTGTCTGGCCATTATCTCACTGC & $63,2^{\circ} \mathrm{C}$ & \\
\multirow{2}{*}{ Éxon 9 } & Forward & CCACACAGCTTGTTGGAGCC & $64,1^{\circ} \mathrm{C}$ & 824 \\
& Reverse & TCACAGTGTAGTGGAGAGCC & $56,3^{\circ} \mathrm{C}$ & \\
\multirow{2}{*}{ Éxon 10 } & Forward & GTCTAGCCAGGTGTGAGTGG & $58,3^{\circ} \mathrm{C}$ & 665 \\
& Reverse & GGCTACATTCACCCAGAGG & $58,1^{\circ} \mathrm{C}$ & \\
\multirow{2}{*}{ Éxon 11 } & Forward & TGCTTCTCATTGAGTTACACC & $55,5^{\circ} \mathrm{C}$ & \multirow{2}{*}{417} \\
& Reverse & TTGTCTTGGGCAGCATGGCC & $68,8^{\circ} \mathrm{C}$ & \\
\multirow{2}{*}{ Éxon 12 } & Forward & TTGGCCCTGGTTCAAGTCC & $63,3^{\circ} \mathrm{C}$ & \multirow{2}{*}{472} \\
& Reverse & CCCACTGGATGCTGCTGAG & $63,0^{\circ} \mathrm{C}$ & \\
\multirow{2}{*}{ Éxon 13 } & Forward & ACTTCATCTCACCCTCCCTC & $58,1^{\circ} \mathrm{C}$ & 597 \\
& Reverse & CCTCTCCTTCTCCCTCTT & $53,3^{\circ} \mathrm{C}$ & \\
\hline
\end{tabular}

Uma alíquota de $4 \mu \mathrm{l}$ de cada produto de PCR, misturado a $4 \mu \mathrm{l}$ de Green GoTaq ${ }^{\circledR}$ Reaction Buffer (Promega ${ }^{\circledR}$ ), foi colocado em gel de agarose a 1,5\% para eletroforese a 100V por 1 hora para confirmar a expansão adequada dos produtos de PCR.

A purificação do produto de PCR foi feita com enzima ExoProStar 1-step (GE Healthcare ${ }^{\circledR}$. Para reação de purificação foi utilizado $3 \mu l$ do produto de PCR, acrescido de $2 \mu \mathrm{l}$ da enzima e $4 \mu \mathrm{l}$ de água tratada com DEPC e autoclavada. A 
solução foi pipetada em placa e colocada em termociclador Eppendorf Mastercycler pro $^{\circledR}$ (seguindo protocolo fornecido pelo LIM 25).

O sequenciamento dos amplicons foi feito por eletroforese capilar (Sanger) em sequenciador ABI 3130xL Genetic Analyzer (Life Technologies ${ }^{\circledR}$ ). Esse sequenciador é equipamento multiusuário da FMUSP e está localizado no Laboratório de Endocrinologia Celular e Molecular (LIM 25). No caso de uma mutação patogênica ser identificada, o sequenciamento foi repetido com o produto de uma nova reação de PCR.

Para análise de produto de sequenciamento, foi utilizado o programa Mutation Surveyor V3.2 (Softgenetics LLC ${ }^{\circledR}$ ). As sequências de referência foram obtidas no site http://www.ncbi.nlm.nih.gov para GRN (RefSeq accession number NG_007886) e para MAPT (Refseq accession number NG_007398). As mutações em GRN foram numeradas tendo como referência NG_007886.1 e NP_002078.1, e as em MAPT, tendo como referência NG_007398.1 e NP_005901.2.

\subsubsection{Determinação dos níveis plasmático de progranulina}

Para dosagem plasmática de progranulina, o sangue coletado em um tubo com EDTA ( $4 \mathrm{ml}$ ) foi centrifugado no mesmo dia da coleta a $1000 \mathrm{xg}$ por 15 minutos, e 0 plasma foi armazenado em freezer a $-20^{\circ} \mathrm{C}$ até as análises. O Kit human Progranulin ELISA (Adipogen Inc. $\circledast$, Seoul, Korea) foi utilizado na determinação dos níveis plasmáticos de progranulina.

As amostras de plasma foram descongeladas e diluídas na proporção 1:100, no diluente fornecido pelo fabricante.

Para montagem da curva padrão, foi utilizada progranulina humana (fornecida pelo fabricante), nas seguintes concentrações: $4 \mathrm{ng} / \mathrm{ml}, 2 \mathrm{ng} / \mathrm{ml}, 1 \mathrm{ng} / \mathrm{ml}, 0,5 \mathrm{ng} / \mathrm{ml}$, $0,25 \mathrm{ng} / \mathrm{ml}, 0,125 \mathrm{ng} / \mathrm{ml}$ e $0,063 \mathrm{ng} / \mathrm{ml}$, além de uma amostra "blank" (0ng/ml).

$\mathrm{Na}$ montagem da placa, $100 \mu \mathrm{l}$ de cada amostra foi pipetada em cada poço. Para cada amostra de plasma e para cada concentração de progranulina humana (padrão), utilizaram-se dois poços (para medida em duplicata). As placas foram então incubadas a $37^{\circ} \mathrm{C}$ por uma hora. O conteúdo de cada poço foi então desprezado, e os

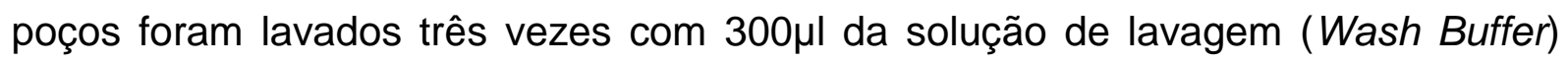


fornecida no kit, diluída a 1x. Então, em cada poço se colocou 100 $\mu$ l do anticorpo de detecção, e as placas foram novamente colocadas em estufa a $37^{\circ} \mathrm{C}$, por uma hora. Após esse período, o conteúdo dos poços era desprezado, e novamente cada poço era lavado três vezes com $300 \mu l$ da solução de lavagem. O passo seguinte consistia na adição de $100 \mu$ l do detector (estreptavidina marcada com HRP [horseradish peroxidase]), diluído a $1 \mathrm{x}$. A seguir, as placas retornaram para a estufa a $37^{\circ} \mathrm{C}$, onde ficaram por mais uma hora.

Os poços então foram lavados com $300 \mu \mathrm{l}$ da solução de lavagem, por cinco vezes. Depois, foi pipetado $100 \mu \mathrm{l}$ de solução do substrato TMB em cada poço e as placas foram deixadas em local escuro, em temperatura ambiente, por 10 minutos,

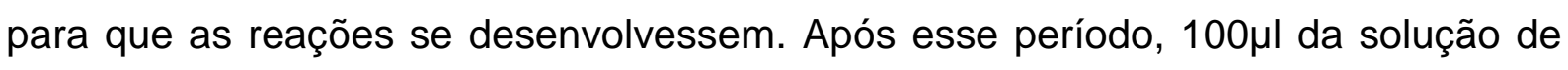
parada foram adicionados a cada poço, fazendo com que a coloração azulada observada após a adição do substrato TMB se tornasse amarelada.

A leitura da placa foi realizada em leitor Synergy HT (Biotek ® ${ }^{\circledR}$ ), e a medida da absorbância foi feita a $450 \mathrm{~nm}$. O cálculo das concentrações foi baseado na curva padrão, desde que o coeficiente $R^{2}$ fosse maior ou igual a 0,99 . $O$ valor da dosagem de progranulina (em $\mathrm{ng} / \mathrm{ml}$ ) é a média aritmética das duas medidas de cada amostra, multiplicada por 100.

A comparação entre os grupos foi feita com o teste Kruskal-Wallis ou o teste Wilcoxon-Mann-Whitney, dependendo do número de grupos incluídos nas análises. $O$ programa estatístico utilizado foi o Stata 12.1 (StataCorp LP ${ }^{\circledR}$ ). 


\section{RESULTADOS}

\subsection{Casuística}

Foram incluídos no estudo 62 probandos com DFT. Os dados demográficos e clínicos da casuística de pacientes estão na Tabela 8.

Tabela 8 - Dados demográficos e clínicos da casuística de DFT

\begin{tabular}{cccccccc}
\hline & N & Sexo & $\begin{array}{c}\text { Idade de } \\
\text { início } \\
\text { dos } \\
\text { sintomas }\end{array}$ & DNM & $\begin{array}{c}\text { Antecedente } \\
\text { familiar de } \\
\text { demência }^{*}\end{array}$ & $\begin{array}{c}\text { Antecedente } \\
\text { familiar de } \\
\text { DFT }^{*}\end{array}$ & $\begin{array}{c}\text { Antecedente } \\
\text { familiar de } \\
\text { DNM/ELA }\end{array}$ \\
\hline vcDFT & 44 & $22 \mathrm{M}: 22 \mathrm{~F}$ & $\begin{array}{c}52,1 \pm 9,7 \\
(35-73)\end{array}$ & 3 & $18(40,9 \%)$ & $10(22,7 \%)$ & $1(2,2 \%)$ \\
vsAPP & 9 & $6 \mathrm{M}: 3 \mathrm{~F}$ & $\begin{array}{c}59,8 \pm 6,4 \\
(48-71)\end{array}$ & 1 & $5(55,5 \%)$ & $2(22,2 \%)$ & 0 \\
vnfAPP & 9 & $2 \mathrm{M}: 7 \mathrm{~F}$ & $\begin{array}{c}63,7 \pm 6,9 \\
(50-71)\end{array}$ & 0 & $5(55,5 \%)$ & $3(33,3 \%)$ & 0 \\
Total & 62 & $30 \mathrm{M}: 32 \mathrm{~F}$ & $\begin{array}{c}54,8 \pm 9,8 \\
(35-73)\end{array}$ & 4 & $28(45,1 \%)$ & $15(24,1 \%)$ & $1(1,6 \%)$ \\
\hline
\end{tabular}

Legenda: $\mathrm{vcDFT}=$ variante comportamental da demência frontotemporal; vsAPP = variante semântica da Afasia Progressiva Primária; vnfAPP = variante não fluente da Afasia Progressiva Primária; $D N M=$ doença do neurônio motor; $E L A=$ esclerose lateral amiotrófica; $F=$ feminino; $M=$ masculino. Dados relativos a idade (em anos): média \pm desvio padrão (variação). ${ }^{*}=$ parente de primeiro grau com quadro demencial (diagnosticado por médico ou baseado em informações da família). \#= parente de primeiro grau com diagnóstico de DFT (diagnosticado por médico ou baseado em informações da família).

A idade média dos probandos no momento da inclusão no estudo foi de $60,4 \pm 9,3$ anos, e a idade variou entre 38 a 79 anos.

Foram incluídos 60 indivíduos no grupo controle, sendo 39 do sexo feminino. A

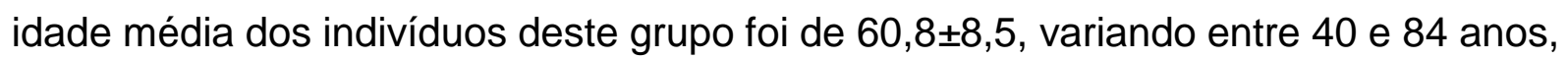
e escolaridade média de $15,1 \pm 6,1$ anos. A pontuação média no MEEM foi de 28,9 (desvio padrão $\pm 1,5$ ).

A idade do grupo dos probandos com DFT (no momento da coleta de sangue) não diferiu da idade do grupo controle ( $p=0,96$, teste Wilcoxon-Mann-Whitney). A distribuição de sexo também não diferiu entre os grupos $(p=0,127$, teste quiquadrado). 


\subsection{Mutações patogênicas encontradas em GRN}

Foram encontradas mutações patogênicas de GRN em seis probandos da casuística, e de MAPT em um probando. Nenhuma das mutações patogênicas foi identificada no grupo controle.

\subsubsection{Probando DFT 11: GRN p.Q257Pfs²6}

A análise do sequenciamento do éxon oito de GRN evidenciou uma duplicação de CC, e por isso a mutação foi identificada como GRN g.10976_10977dupCC. Tratase de uma mutação frameshift que leva a substituição de glutamina (CAG) por prolina (CCC) e formação de códon de parada prematuro no éxon 9, e por isso também pode ser denominada de GRN p.Q257Pfs*26 (Figura 4).

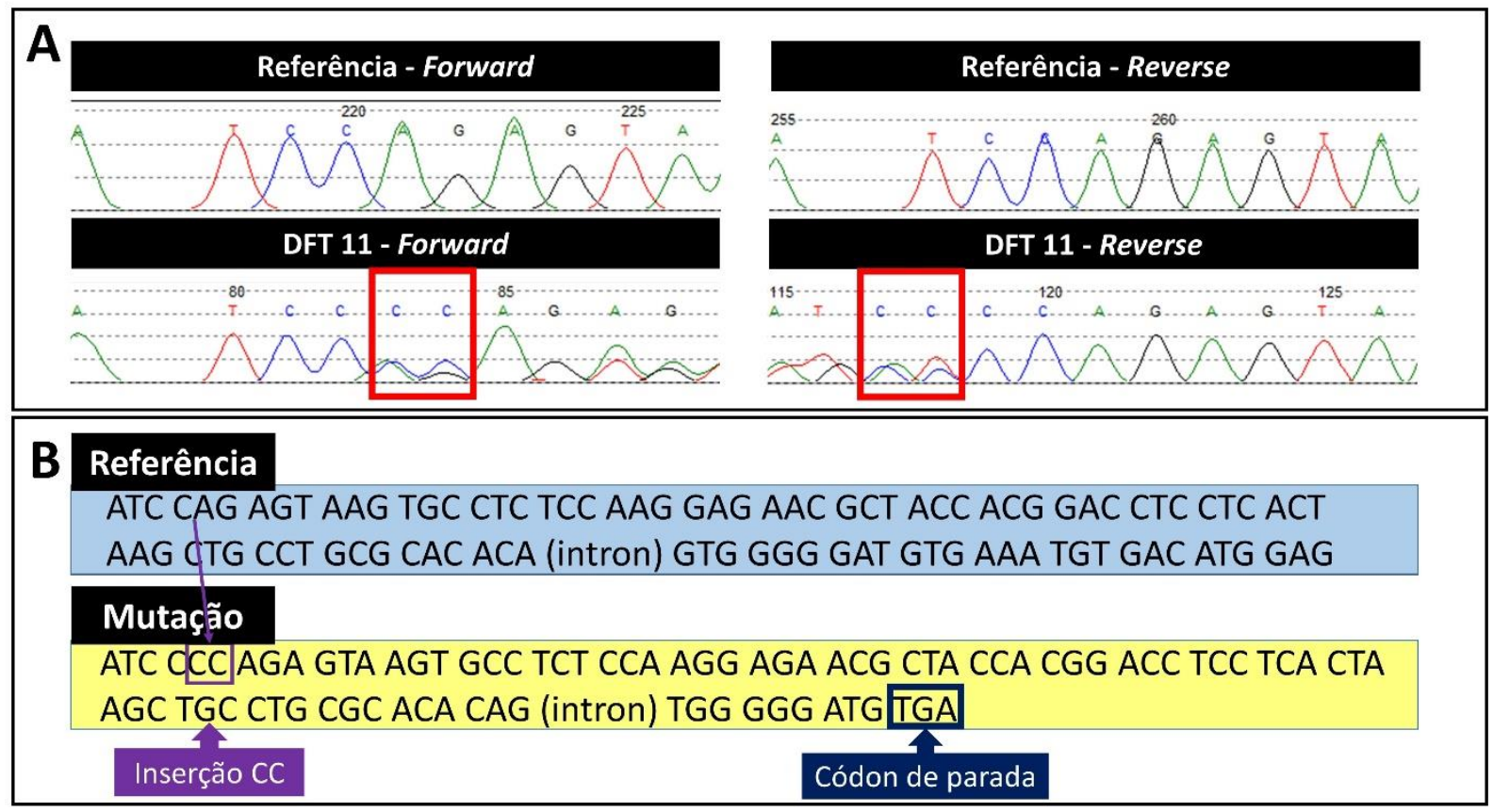

Figura 4 - Mutação GRN p.Q257Pfs*26

Legenda: (A) Cromatograma mostrando a mutação GRN g.10976_10977dupCC, em vermelho;

(B) Esquema que mostra a formação de códon de parada no éxon 9 devido a inserção de duas bases CC no éxon 8. 
O probando DFT 11 era uma paciente do sexo feminino, que foi avaliada pela primeira vez no GNCC-HCFMUSP em 2010, quando tinha 62 anos. Sua escolaridade era de 4 anos. Na primeira consulta, a paciente e sua filha relataram esquecimento que se iniciara 2 ou 3 anos antes, de coisas do dia-a-dia, como panela no fogo, ou datas. Um ano antes da consulta, começaram a notar uma dificuldade na fala, que descreveram como "gagueira", de piora progressiva.

O exame físico geral foi normal. Na avaliação cognitiva, a paciente apresentava fala não fluente e dificuldade no planejamento motor da fala. Na fala espontânea, foram notados erros como substituições e distorções de fonemas, que eram inconsistentes. A dificuldade era mais evidente para palavras longas, palavras de baixa frequência, e não palavras, caracterizando uma apraxia da fala. No MEEM, ${ }^{341}$ sua pontuação foi de 18 pontos, tendo perdido três pontos em orientação temporal, um ponto em orientação espacial, cinco pontos em cálculo, um ponto na evocação tardia, um ponto na escrita e um ponto na cópia do desenho. Na ordem de dígitos direta, a paciente repetiu quatro números, e na ordem inversa, dois números. $\mathrm{Na}$ Bateria Breve de Rastreio Cognitivo (BBRC), ${ }^{343}$ a paciente nomeou e percebeu corretamente as dez figuras. Nas etapas de memória incidental, memória imediata e aprendizado, as pontuações foram de quatro, seis e cinco, respectivamente. $\mathrm{Na}$ memória tardia, a paciente se recordou de quatro figuras, e no reconhecimento, sua pontuação foi de dez. No teste do desenho do relógio ${ }^{344}$, sua pontuação foi de quatro em dez. A fluência verbal semântica foi de nove animais, e a fluência verbal fonêmica foi de três palavras com P. O restante do exame neurológico foi normal.

A ressonância magnética de encéfalo realizada em 2010 mostrava atrofia predominante em região perisilviana a esquerda (Figura 5). A cintilografia de perfusão cerebral solicitada na primeira consulta mostrou hipofluxo sanguíneo cerebral regional nos lobos frontais, mais evidente à esquerda, e em lobo temporal esquerdo. 


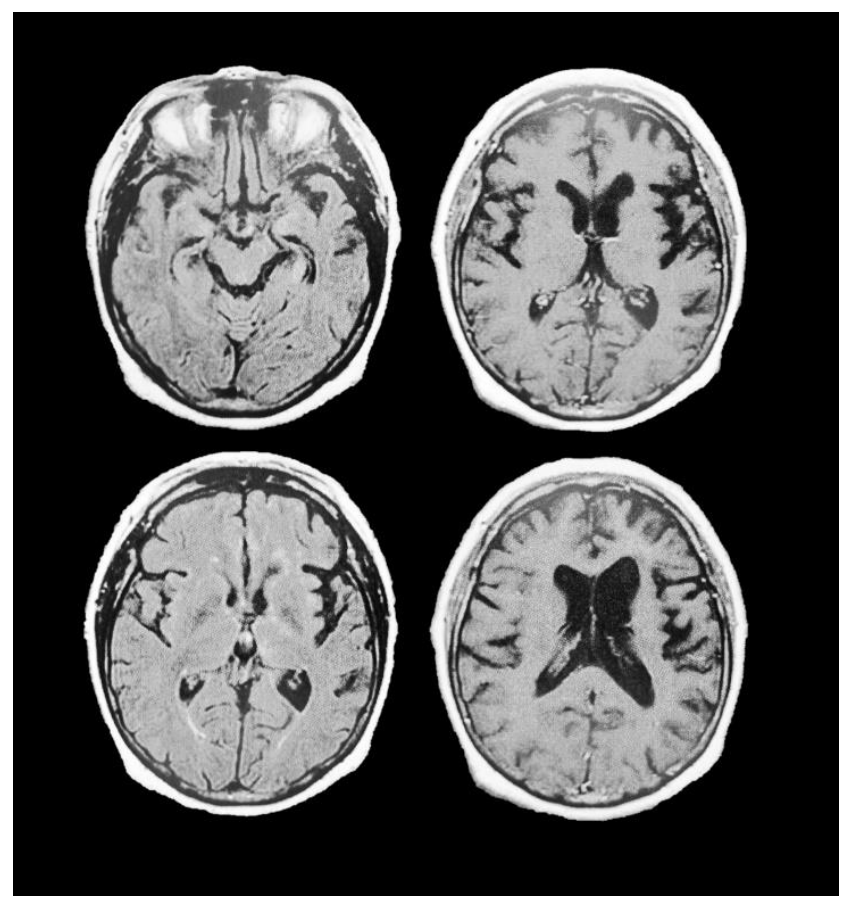

Figura 5 - Neuroimagem do probando DFT 11

Legenda: Ressonância magnética de encéfalo - cortes axiais de sequência ponderada em T1 que mostram atrofia que predomina em região perisilviana esquerda.

Com base na avaliação e exames complementares, a paciente recebeu diagnóstico de vnfAPP com apraxia da fala. A paciente retornou mais duas vezes ao ambulatório, e nas consultas foi relatado declínio progressivo da linguagem. No entanto, a paciente foi a óbito aos 64 anos (cerca de um ano após o início do acompanhamento no GNCC-HCFMUSP), por complicações decorrentes de uma úlcera péptica. Segundo informações obtidas com a filha da paciente, ela não havia desenvolvido sintomas motores até o falecimento.

A história familiar da paciente era negativa para DFT, mas a mãe da paciente foi diagnosticada com DA pré-senil (I-1, Figura 6). Ela começou a apresentar dificuldades cognitivas por volta dos 63 anos, caracterizadas por esquecimento de fatos recentes e apatia. $O$ quadro foi progressivo, e posteriormente ela desenvolveu alucinações visuais e comprometimento motor. O óbito ocorreu aos 73 anos, quando ela já se encontrava acamada e com comprometimento cognitivo grave. Os irmãos do probando (II-1, II-3, II-4 e II-5, Figura 6) estão atualmente com idades entre 49 e 69 anos, e não apresentam sintomas cognitivos ou comportamentais. Os filhos da paciente (III-1, III-2 e III-3, Figura 6) têm entre 30 e 44 anos, e são hígidos. 


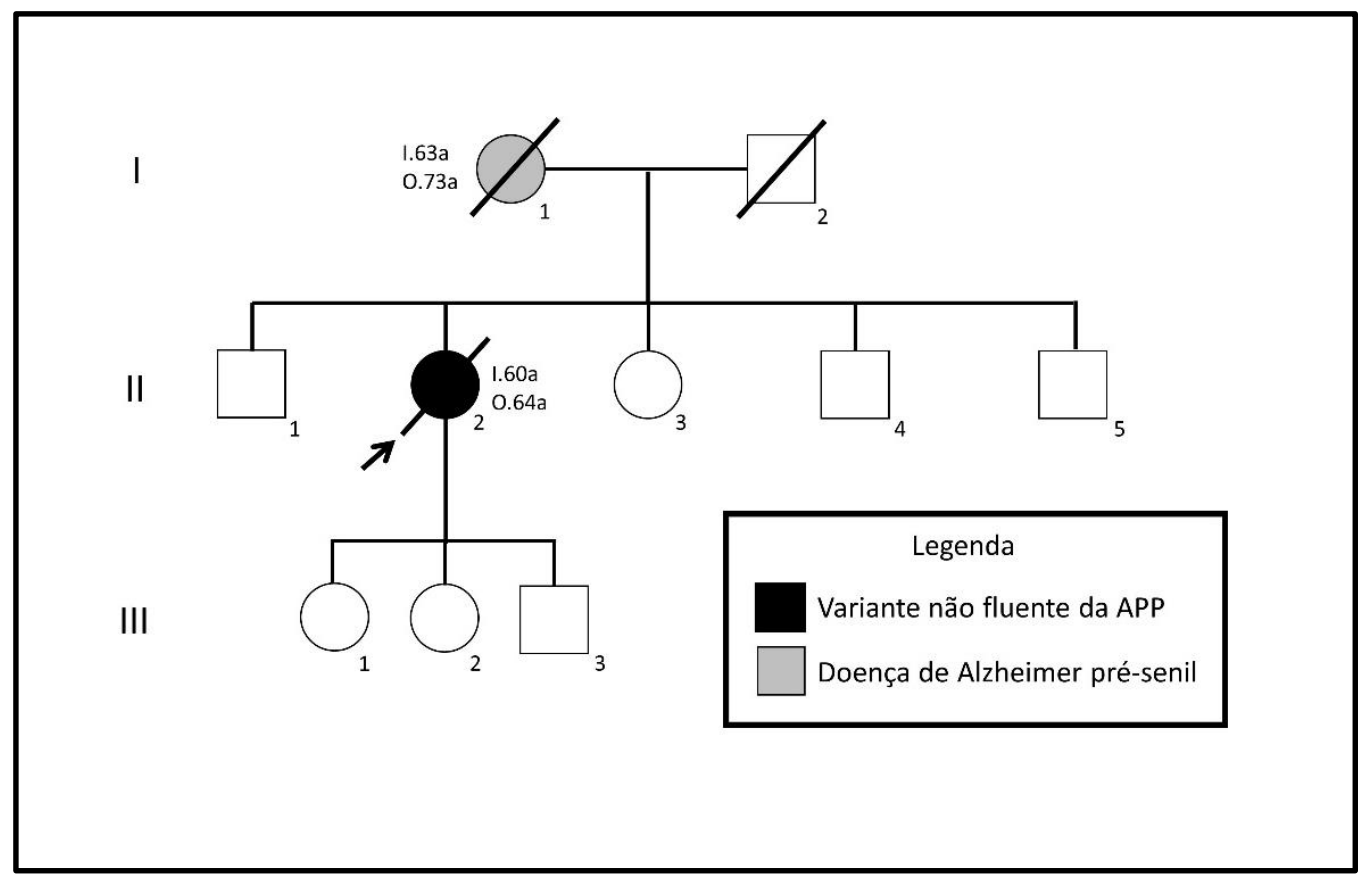

Figura 6 - Heredograma da família do probando DFT 11

Legenda: A seta indica o probando (II-2). Círculos representam mulheres e quadrados representam homens. A linha diagonal indica que o indivíduo já faleceu. $\mathrm{I}=$ idade de início dos sintomas. $\mathrm{O}=$ idade de óbito.

\subsubsection{Probando DFT 22: GRN p.Q300X}

A análise do sequenciamento do gene $G R N$ do probando DFT 22 revelou uma substituição de $C$ por T no éxon 9, levando a formação de um códon de parada (TAG) prematuro (Figura 7). Esta mutação nonsense é identificada como GRN g.11303C>T ou GRN p.Q300X. 


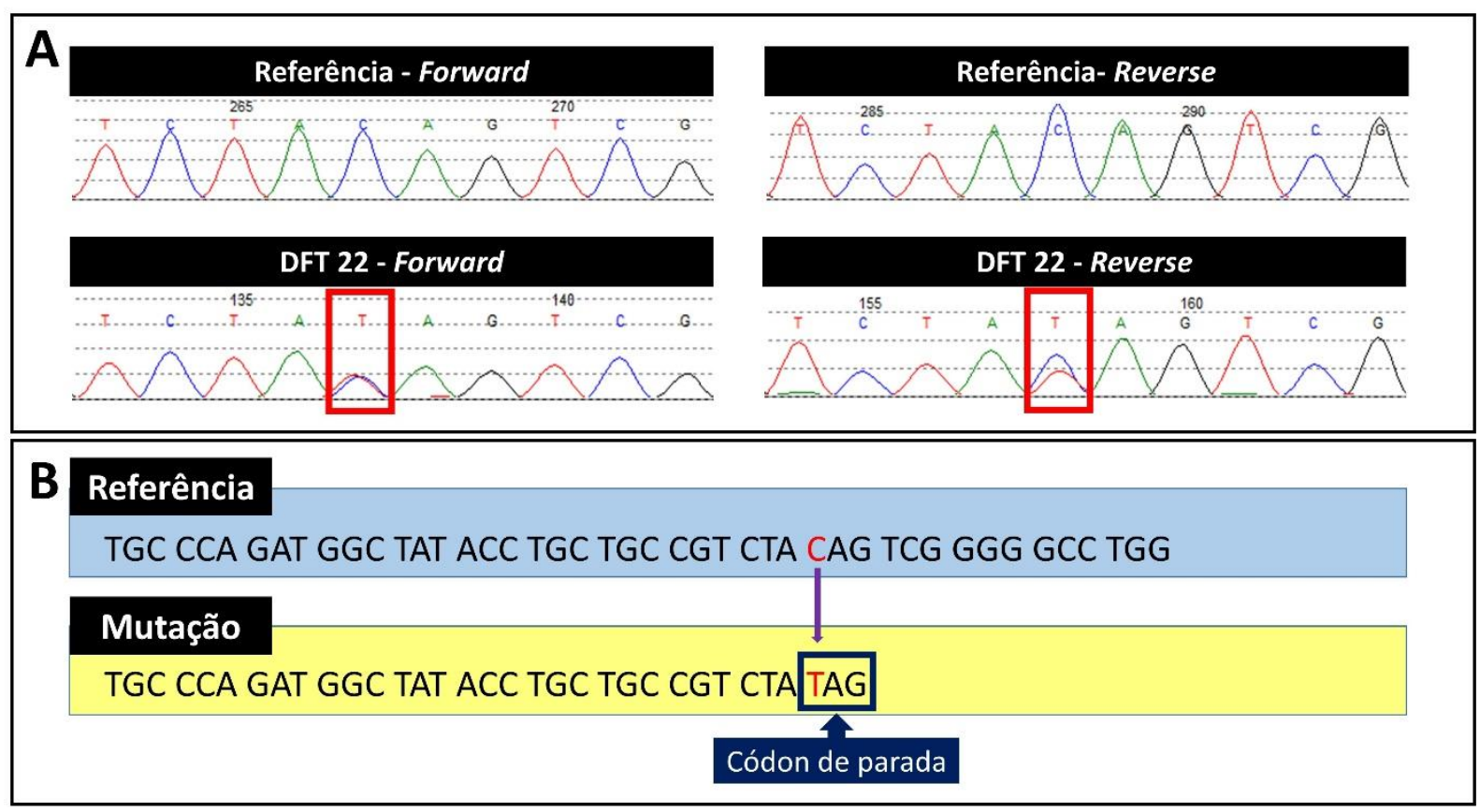

Figura 7 - Mutação GRN p.Q300X

Legenda: (A) Cromatograma mostrando a mutação GRN g.11303C>T em vermelho; (B) Esquema que mostra que a substituição de uma citosina por timina transforma o códon CAG (que codifica glutamina) em um códon de parada (TAG).

O probando DFT 22 é uma paciente do sexo feminino, destra, com ensino superior completo. Foi avaliada pela primeira vez no GNCC-HCFMUSP em Janeiro de 2011, quando tinha 64 anos. Queixava-se de "gaguejar" há cerca de 4 meses. Notava que a dificuldade à fala era maior quando tentava falar palavras mais longas e relatava também leve dificuldade para encontrar palavras. Apesar dessas queixas, era independente e morava sozinha. Ela não tinha outras comorbidades.

Na primeira avaliação, sua pontuação no MEEM ${ }^{341}$ foi de 30 . Sua pontuação no teste de fluência verbal semântica (animais) foi de 17 e fonêmica (palavras que iniciam com letra $\mathrm{P}$ ) foi de 10 . Ao exame neurológico apresentava leve apraxia de fala e dificuldade em realizar marcha em tandem. Foi submetida a uma avaliação neuropsicológica que demonstrou déficit moderado a grave em controle inibitório e flexibilidade mental, e preservação de memória episódica, abstração, memória operacional e fluência verbal semântica. Apresentou dificuldade leve no teste de fluência verbal fonêmica e em testes de amplitude atencional auditiva.

A ressonância magnética de encéfalo realizada em 2010 apresentava moderado alargamento da fissura silviana à esquerda (Figura 8). Notava-se também 
leve alargamento de sulcos em regiões frontal dorsolateral e temporal lateral do lado esquerdo. A cintilografia de perfusão cerebral mostrou diminuição de radiofármaco em grau moderado em regiões frontal, temporal e parietal esquerdas.

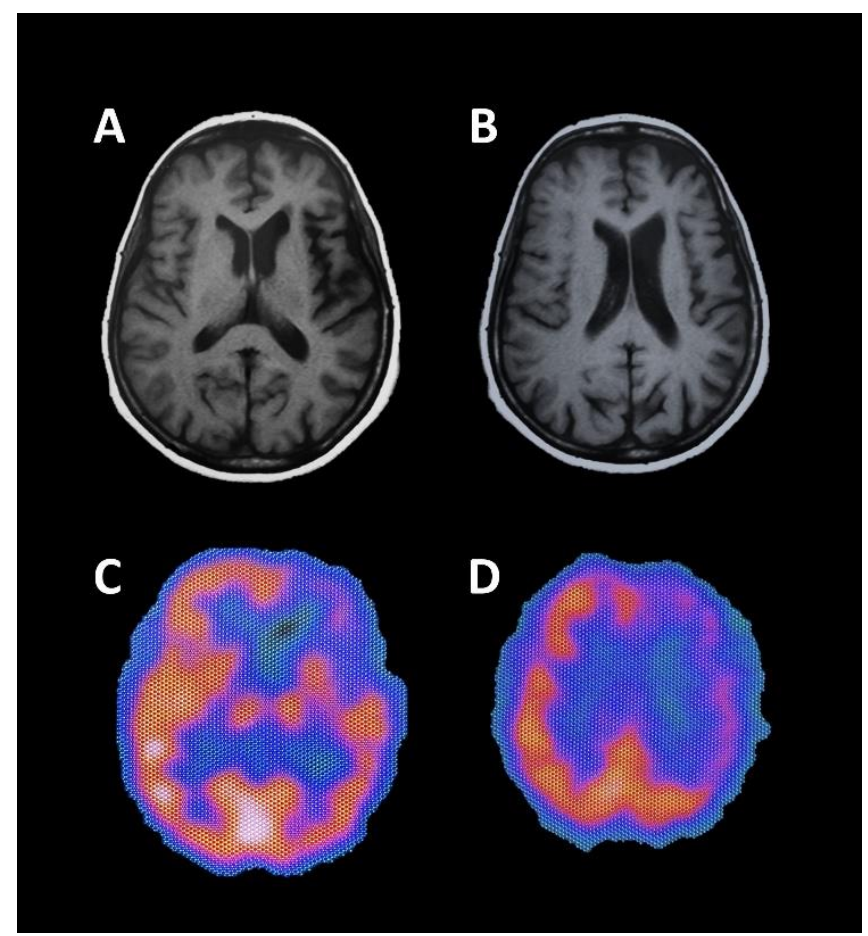

Figura 8 - Neuroimagem do probando DFT 22.

Legenda: A/B: cortes axiais de Ressonância Magnética de Encéfalo mostrando alargamento de sulcos predominando em região frontal à esquerda, com alargamento da fissura sylviana. C/D: Cintilografia de perfusão cerebral mostrando hipofluxo em regiões frontais e parietais à esquerda. Exames realizados no primeiro ano de sintomas.

A paciente recebeu diagnóstico de vnfAPP. A paciente não foi mais acompanhada no GNCC-HCFMUSP, mas sua sobrinha relatou piora progressiva dos sintomas desde então. Cerca de um ano e meio após a avaliação inicial, a paciente já não conseguia dirigir e tinha dificuldades com algumas tarefas domésticas, como desligar o fogão. Ela inicialmente morava sozinha, mas devido ao declínio cognitivo e motor (particularmente de marcha), tornou-se progressivamente cada vez mais dependente. Em Novembro de 2013 já se encontrava totalmente dependente para atividades básicas de vida, e recebia auxílio de cuidadores 24 horas por dia. 
Em relação a antecedentes familiares (Figura 6), contou que sua mãe (II-6) fora diagnosticada com DA, e uma tia-avó materna (l-1) faleceu com quadro demencial por volta dos 68 anos. Os sintomas da mãe da paciente se iniciaram por volta de 53 anos, com alteração de comportamento caracterizada por agressividade e esquecimentos. Foi internada em ala psiquiátrica, onde recebeu diagnóstico de DA. Próximo ao seu falecimento, tinha dificuldade para falar, andar e controlar esfíncteres. O irmão da paciente (III-2) foi diagnosticado com vcDFT aos 57 anos de idade e está vivo, aos 64 anos, mas com comprometimento cognitivo e motor grave. Os sintomas se iniciaram com agressividade, e após 3 anos, evoluiu com embotamento afetivo, redução progressiva da fala e capacidade de auto-cuidado. Posteriormente começou a apresentar dificuldade para andar, e atualmente encontra-se acamado. Não foi possível o sequenciamento do gene do indivíduo III-2, por problemas técnicos, mas o nível de progranulina no plasma foi baixo e similar aos outros indivíduos com mutação em GRN.

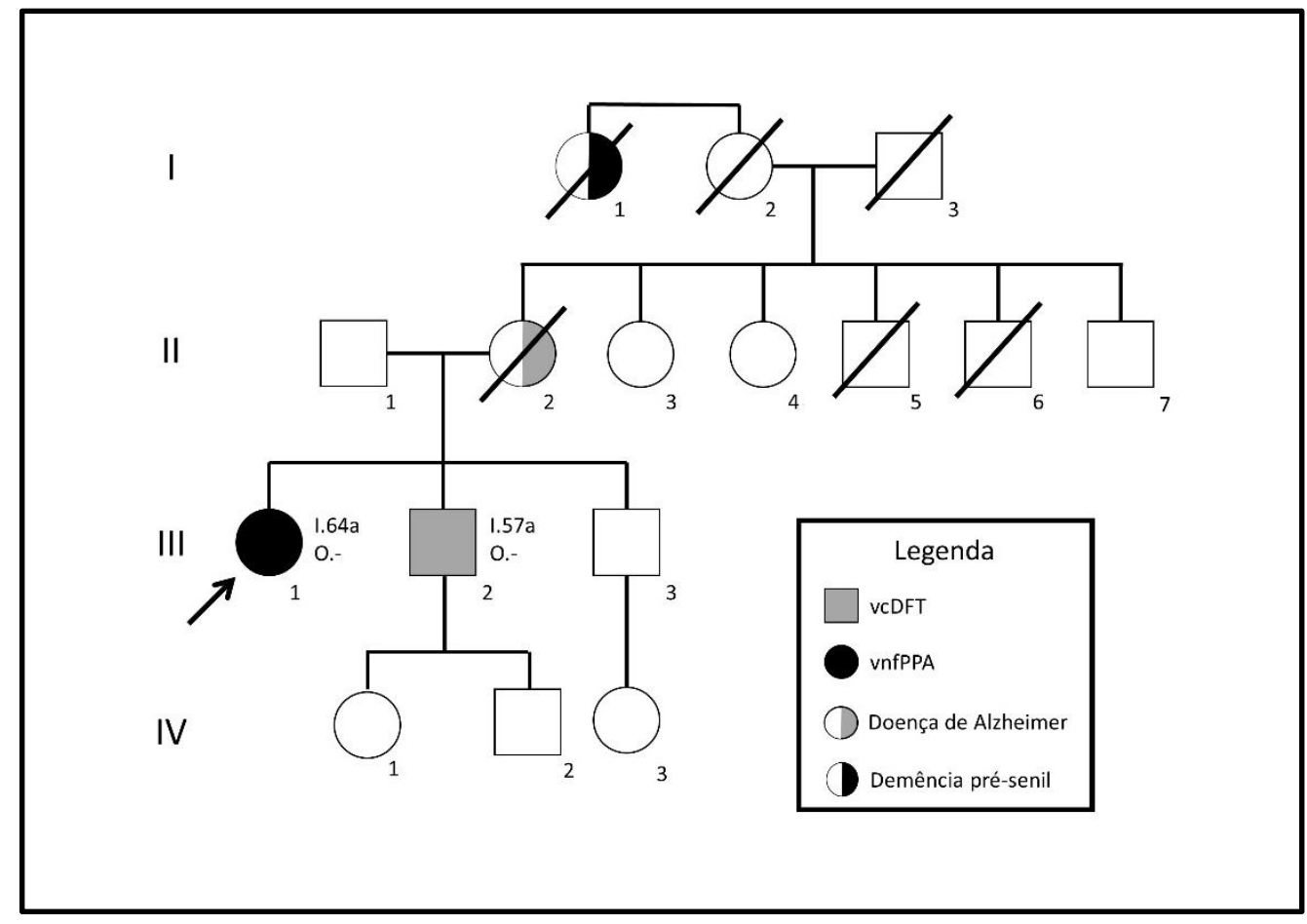

Figura 9 - Heredograma da família do probando DFT 22

Legenda: A seta indica o probando (III-1). Círculos representam mulheres e quadrados representam homens. A linha diagonal indica que o indivíduo já faleceu. $\mathrm{I}=$ idade de início dos sintomas. $\mathrm{O}=$ idade de óbito. 


\subsubsection{Probando DFT 53: GRN p.V200Gfs ${ }^{\star} 18$}

A análise do sequenciamento de GRN do probando DFT 53 revelou uma substituição de G por C em sítio 5' doador de splicing do éxon 7 (Figura 8). Essa variante é identificada como o SNP rs63749817, e pode ainda receber as seguintes denominações: g.10679G>C, p.V200Gfs 18 , ou ainda IVS7+1G>C.

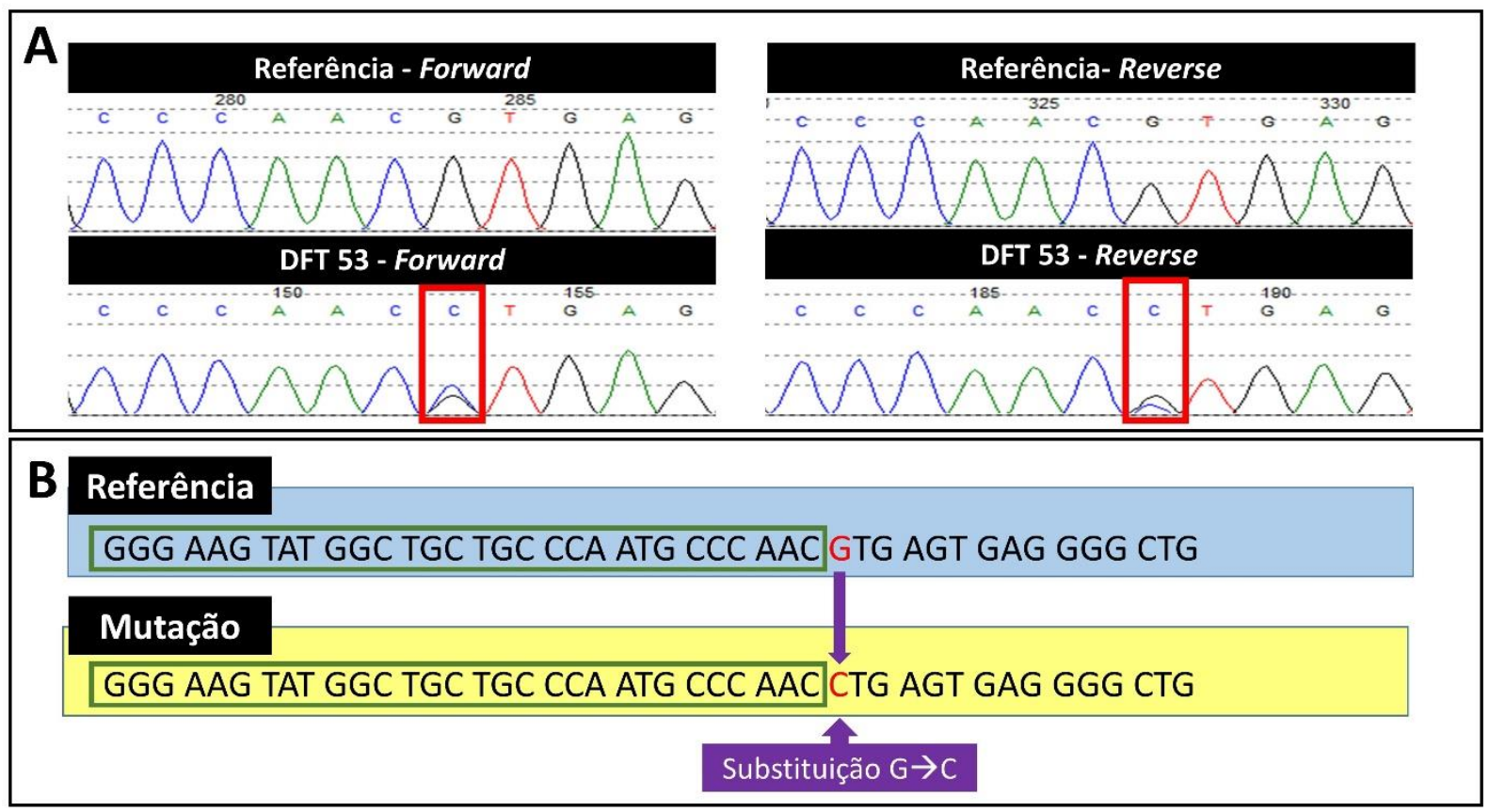

Figura 10 - Mutação GRN p.V200Gfs*18

Legenda: (A) Cromatograma mostrando a mutação GRN g.10679G>C; (B) Esquema que mostra posição da mutação, no sítio doador de splicing do éxon 7. Parte da sequência do éxon 7 está indicada pelo retângulo verde.

O probando DFT 53 foi avaliado pela primeira vez no GNCC-HCFMUSP em março de 2013, quando tinha 66 anos de idade. Paciente destro e com quatro anos de escolaridade apresentou-se com queixa de dificuldade para encontrar palavras de piora progressiva, que iniciou um ano e meio antes, quando tinha 64 anos. E três meses antes da consulta, seus familiares começaram a notar também dificuldade para compreensão. Os familiares relataram poucas alterações comportamentais. No inventário neuropsiquiátrico, ${ }^{345}$ foram relatadas a presença de sintomas depressivos, apatia, irritabilidade e perda de apetite, com pontuação total de 21 . 
Como antecedentes pessoais, tem diabete melito e hipertensão arterial sistêmica, além de alcoolismo e tabagismo até os 65 anos.

Ao exame neurológico, o paciente apresentava fala não fluente, com pausas e uso frequente de palavras como "coisa". Devido ao comprometimento grave da fala, não foi possível aplicar o MEEM. Ao se perguntar o mês, o paciente falou "sessenta", enquanto mostrava com os dedos o número 66 (sua idade). 0 paciente não apresentava alterações ao exame motor e de marcha.

$\mathrm{Na}$ avaliação de linguagem realizada entre dezembro de 2013 e fevereiro de 2014, observou-se preservação relativa da compreensão de frases e ordens simples, enquanto que a expressão estava restrita a emissão de poucas palavras e vocalizações. Foram observadas algumas características de apraxia da fala, como redução da velocidade de fala, perseverações, tentativas de auto-correção, ensaios articulatórios, dificuldade para iniciar a fala e alteração da prosódia. No Bedside Evaluation Screening Test for Aphasia (BEST-2), ${ }^{346}$ o paciente apresentou comprometimento leve para apontar objetos e moderado para apontar partes de figura. Nos demais subtestes, o comprometimento foi grave. No teste de nomeação de Boston, ${ }^{347}$ foram apresentados apenas 10 dos 60 estímulos. $O$ paciente não foi capaz de nomear esses dez estímulos espontaneamente, mas quando as respostas foram apresentadas como múltipla escolha respondeu nove corretamente (e teve resposta gestual apropriada para o décimo estímulo). No Pyramids and Palm Trees test $^{348}$ o paciente acertou $46 \%$ dos estímulos, o que indicou comprometimento moderado da memória semântica. Devido aos indícios de que a memória semântica estava menos comprometida do que a emissão oral, foi sugerida da hipótese de vnfAPP.

As ressonâncias magnéticas de encéfalo realizadas em setembro e novembro de 2012 (Figura 11) mostraram atrofia que predominava em região perisilviana a esquerda e no lobo temporal anterior à esquerda, mas também com aumento de sulcos em regiões frontais e parietais do mesmo lado. Foram observados alguns focos de hipersinal em substância branca, na sequência FLAIR, que poderiam corresponder a gliose ou microangiopatia (Figura 11-A). A tomografia por emissão de pósitrons com fluordeoxiglicose realizada em março de 2014 (Figura 11-C) revelou hipometabolismo marcada nos lobos frontais e temporais a esquerda, com extensão para o lobo parietal 
e cíngulo posterior. No líquido cefalorraquidiano, os níveis das proteínas amiloide $\beta_{1}$ $42(1228 \mathrm{pg} / \mathrm{ml})$, tau $(185 \mathrm{pg} / \mathrm{ml})$ e fosfo-tau $(13 \mathrm{pg} / \mathrm{ml})$ foram normais.
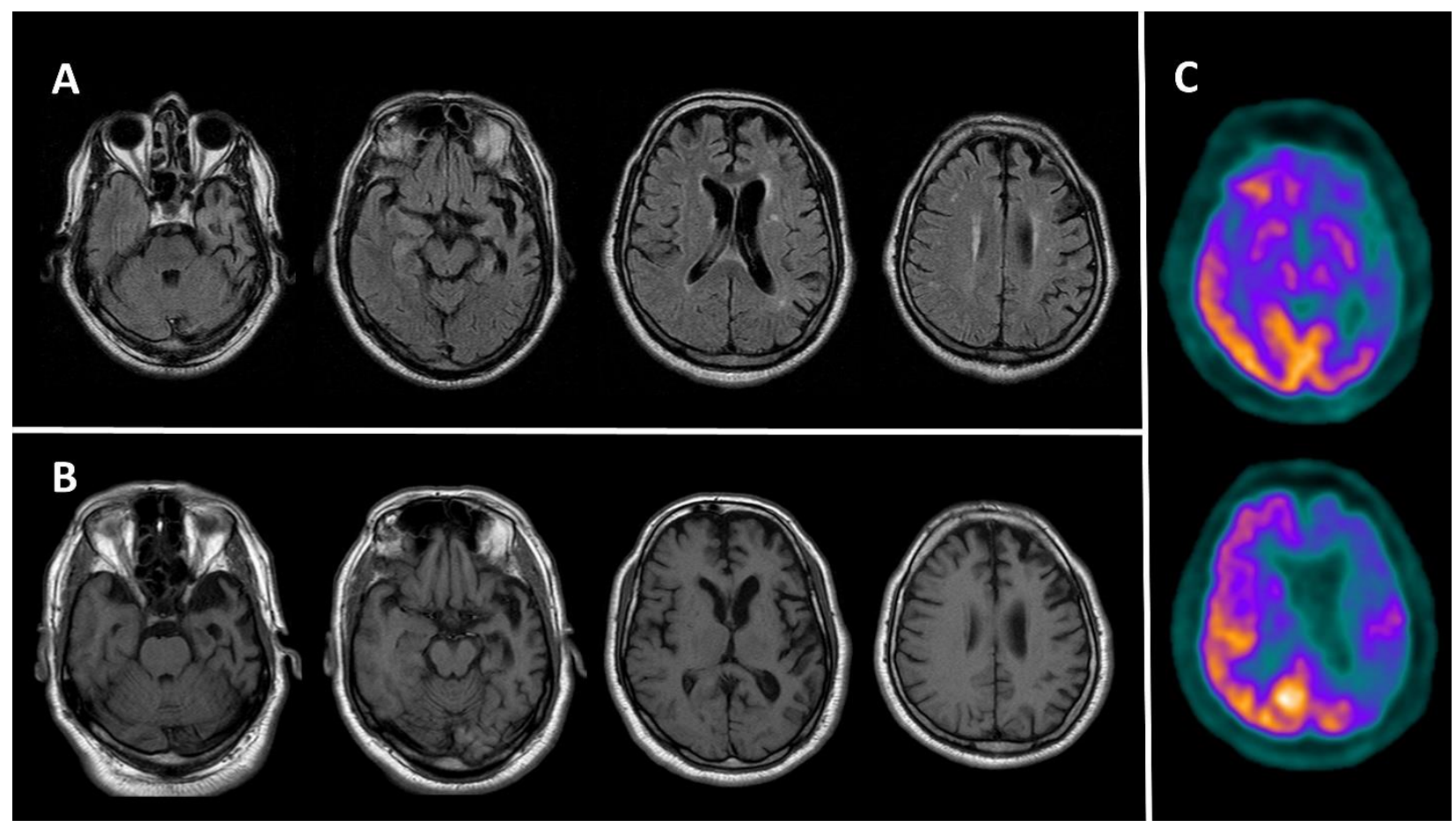

Figura 11 - Neuroimagem do probando DFT 53

Legenda: Ressonância magnética do encéfalo $(A)$ cortes axiais na sequência FLAIR, mostrando atrofia em lobos temporal e frontal à esquerda, associado a aumento de sulcos em regiões parietal à esquerda e frontal à direita. Notam-se alguns focos de hiperssinal na substância branca. (B) cortes axiais em sequência $T 1$, realizada dois meses após a imagem (A), mostrando alterações similares. (C) Tomografia por emissão de pósitrons com fluordeoxiglicose (FDG-PET) mostrando hipometabolismo em região frontotemporal esquerda de grau acentuado, com extensão em grau moderado para a região parietal posterior e cíngulo posterior ipsilateral.

O paciente vem evoluindo com piora progressiva do quadro cognitivo. Em sua última consulta no GNCC-HCFMUSP, em janeiro de 2015, a esposa do paciente relatou que ele estava precisando de auxílio para se ensaboar no banho e se barbear, e por vezes urinava em locais inapropriados. Estava mais apático, mas continuava passando o dia todo sozinho e conseguia andar na vizinhança sem se perder. Durante a consulta, não foi capaz de nomear objetos simples como caneta, mesa, ou relógio. Apontou corretamente seu nariz e orelha, mas apontou para a boca quando o examinador pediu para apontar para a mesa. 
A história familiar do probando DFT 53 sugere uma doença de caráter autossômico dominante (Figura 12). Vários dos familiares acometidos iniciaram os sintomas com distúrbio de fala, o que poderia ser indicativo de um quadro de APP. Os pais do probando DFT 53 eram primos de primeiro grau (I-1 e I-2, Figura 12). Ambos desenvolveram um quadro demencial que se iniciou com dificuldade na fala antes dos 65 anos de idade, e faleceram aos 70 anos. Há relato de que o pai do probando teve um acidente vascular cerebral, mas os problemas cognitivos precediam esse evento. Quatro dos irmãos do probando faleceram, entre 65 e 70 anos. Desses irmãos, dois (II-9 e II-10) faleceram com quadro demencial que foi atribuído a doença cerebrovascular. A irmã II-8 iniciou com quadro de dificuldade a fala aos 65 anos, e posteriormente evoluiu com quadro demencial rapidamente progressivo. Um laudo de tomografia de crânio da época relatava "moderada dilatação assimétrica dos ventrículos laterais com predomínio a esquerda". A irmã II-7 também começou a apresentar dificuldade para falar por volta dos 65 anos, e foi gradativamente perdendo a funcionalidade. Ao final de sua doença, estava em mutismo. Laudos de tomografia computadorizada de crânio dessa paciente descreviam lesões hipodensas na coroa radiada a esquerda em 2002, e quatro anos depois, áreas de hipodensidade na substância branca bilateralmente. O indivíduo II-6 começou a apresentar sintomas cognitivos aos 68 anos, que não foram bem caracterizados. A irmã do probando II-5 tem atualmente 69 anos. Iniciou com dificuldade de fala, e posteriormente desenvolveu alteração de marcha. $O$ probando tem três irmãos que não apresentam sintomas cognitivos, com idades entre 58 e 70 anos (II-1, II-2, e II-4). 


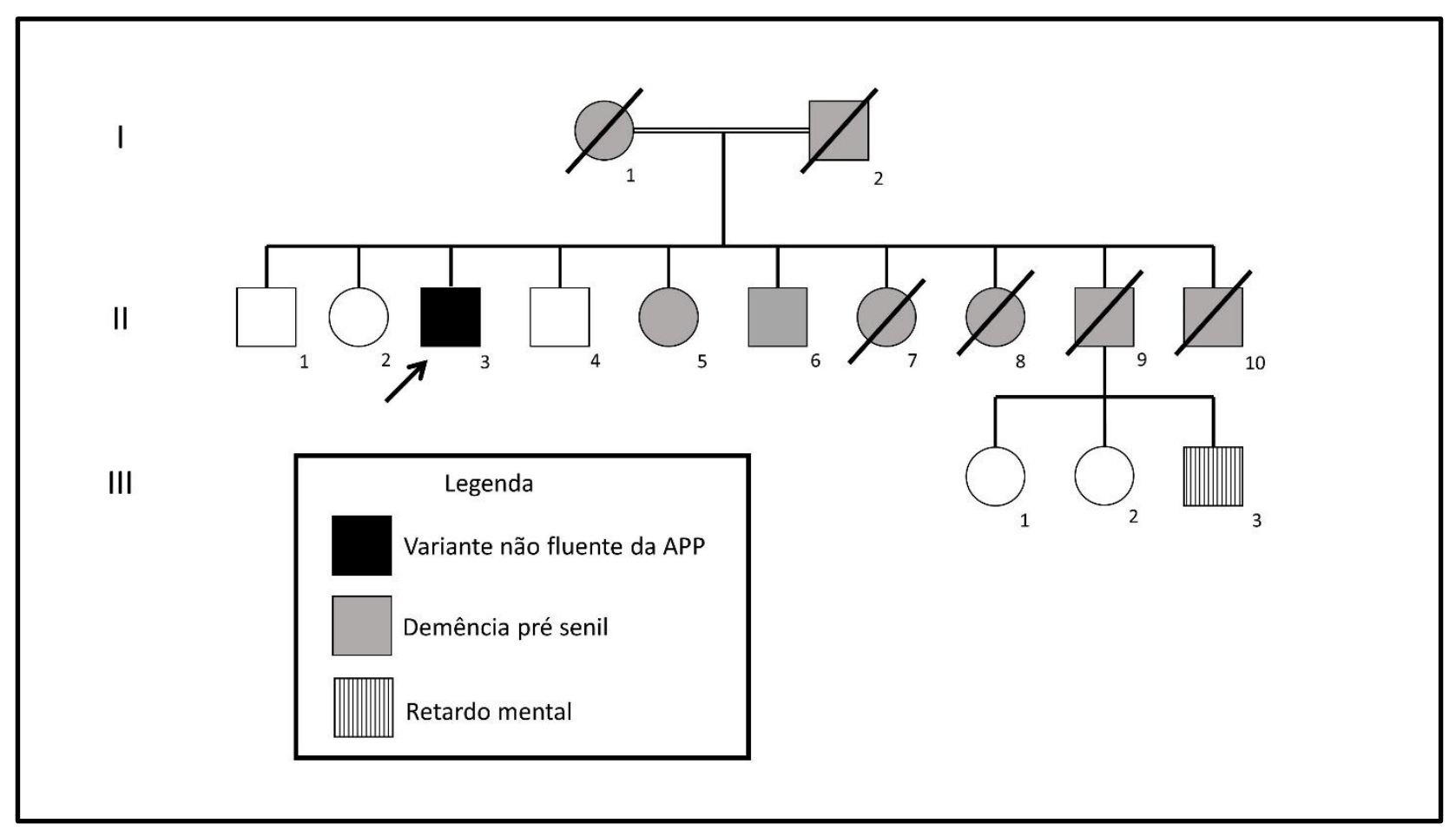

Figura 12 - Heredograma da família do probando DFT 53

Legenda: A seta indica o probando (III-1). Círculos representam mulheres e quadrados representam homens. A linha diagonal indica que o indivíduo já faleceu. I= idade de início dos sintomas. $\mathrm{O}=$ idade de óbito.

\subsubsection{Probando DFT 58: GRN p.Q130X}

Foi encontrada uma substituição de citosina por timina no éxon 5 de $G R N$, que levou à formação de um códon de parada precoce (Figura 13). Essa mutação nonsense pode ser denominada de GRN g.10144C>T ou GRN p.Q130X. 


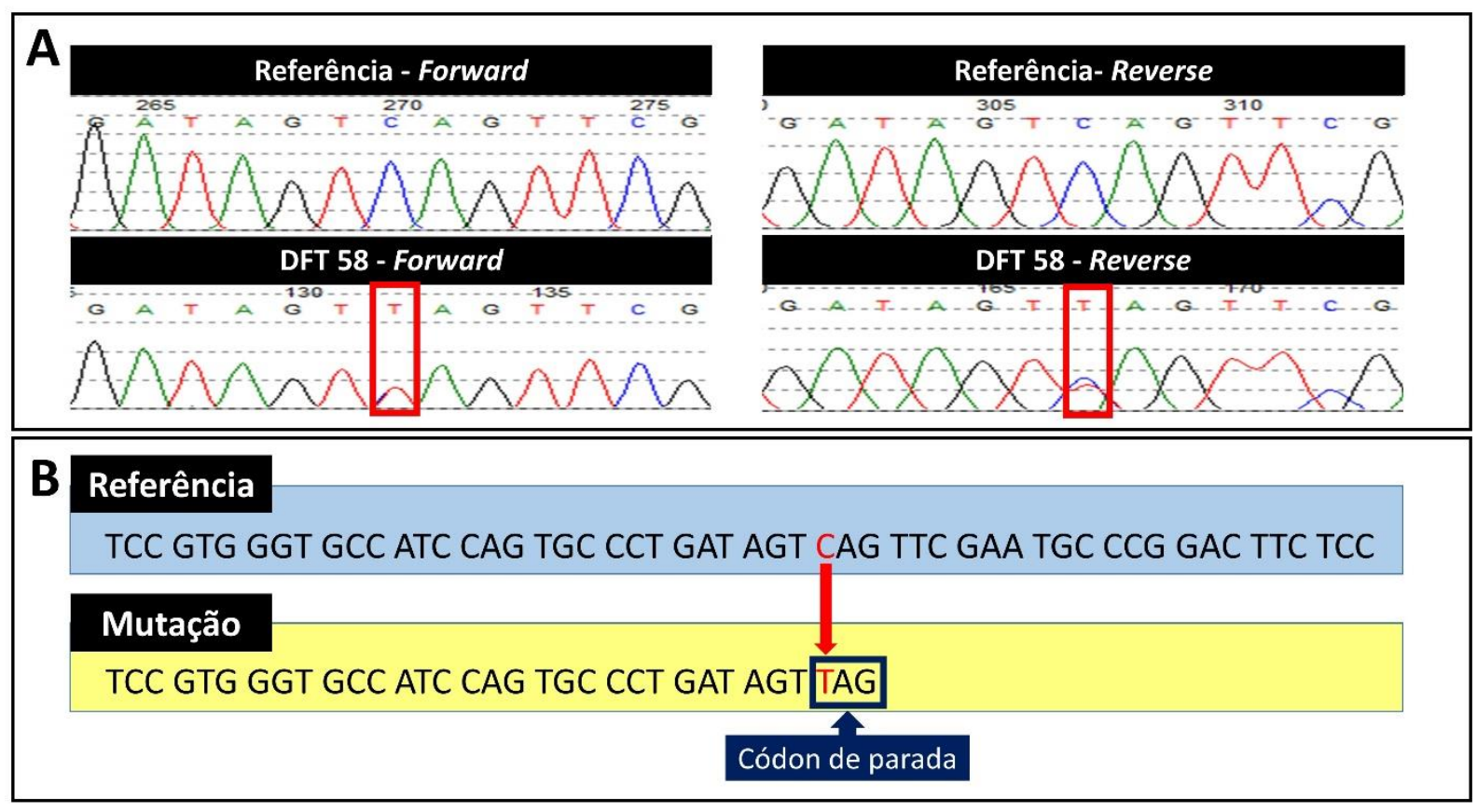

Figura 13 - Mutação GRN p.Q130X

Legenda: (A) Cromatograma mostrando a mutação GRN g.10144C $>T$ (em vermelho); (B) Esquema que mostra posição da mutação no éxon 5 . A substituição de citosina por timina leva a formação de um códon de parada (TAG) no códon que codifica glutamina (CAG).

Obtivemos o DNA da paciente DFT 58 e de sua irmã (III-1, Figura 14), e o sequenciamento do DNA de ambas revelou a mesma mutação. A história familiar é limitada, como se pode ver na Figura 14. A mãe das pacientes faleceu aos 60 anos por tromboembolismo pulmonar (sem história de comprometimento cognitivo) e a avó materna apresentou quadro demencial de início pré-senil (por volta dos 50 anos). 


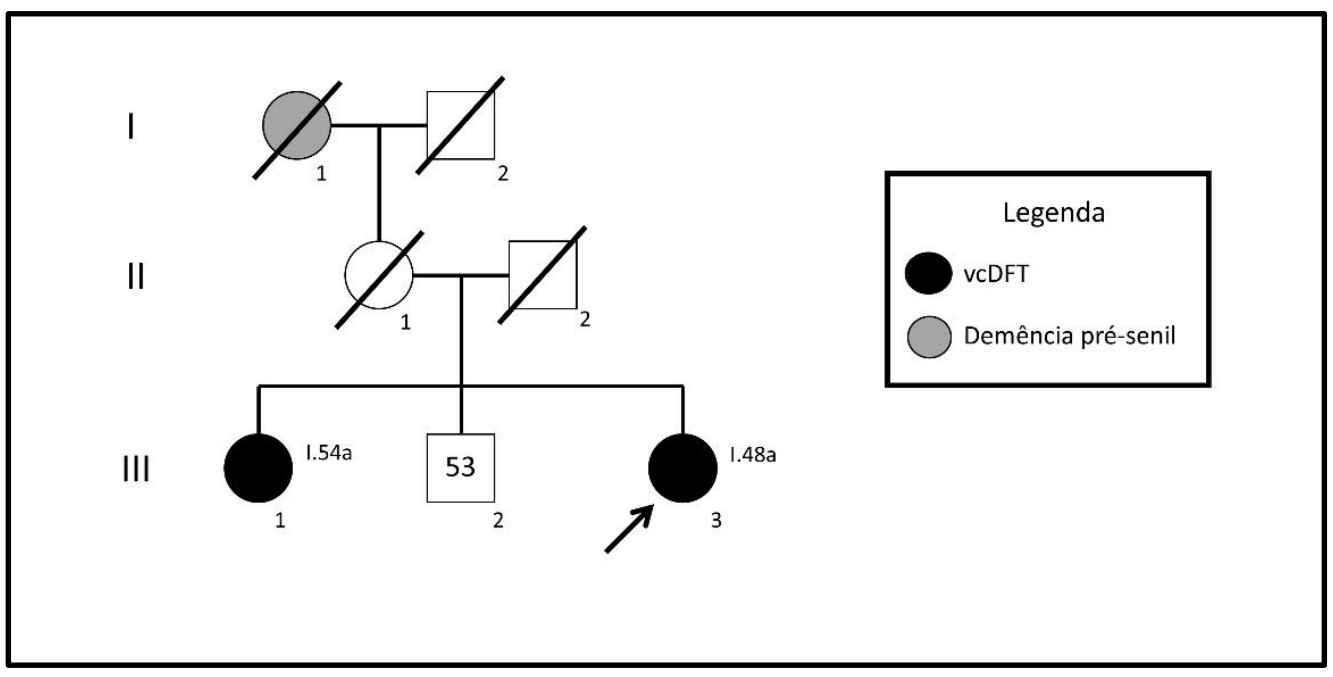

Figura 14 - Heredograma da família do probando DFT 58

Legenda: A seta indica o probando. Círculos representam mulheres e quadrados representam homens. A linha diagonal indica que o indivíduo já faleceu. I= idade de início dos sintomas. $\mathrm{O}=$ idade de óbito.

Paciente (III-3, Figura 14) do sexo feminino, destra, com ensino superior completo (médica) foi avaliada pela primeira vez em 2011, quando tinha 50 anos. Dois anos antes iniciara com esquecimentos de fatos recentes (por exemplo, esquecia itens de lista de supermercado) e desorientação topográfica; posteriormente evoluiu com dificuldade para se expressar. No MEEM sua pontuação foi de $19 .{ }^{341}$ Perdeu três pontos em orientação temporal, dois pontos em orientação espacial, três pontos em cálculo, e três pontos em evocação. A fluência verbal semântica (categoria animais) foi de 22. $\mathrm{Na} \mathrm{BBRC}{ }^{343}$ sua evocação tardia foi de quatro itens, e reconhecimento de 10 itens. O restante do exame neurológico era normal. A ressonância magnética de encéfalo mostrava aumento difuso de sulcos e fissuras corticais e focos de hiperssinal em substância branca, além de cisto de aracnóide em região temporal anterior direita. A cintilografia de perfusão cerebral (SPECT) mostrou hipometabolismo frontal e têmporo-parietal bilateral e FDG-PET mostrou hipometabolismo frontal, de cíngulo anterior e têmporo-parietal bilateral.

Inicialmente seu diagnóstico foi de DA possível, mas posteriormente a paciente evoluiu com dificuldade progressiva de fala e alterações comportamentais que levaram a mudança do diagnóstico para vcDFT. Apresentava fala não fluente, entrecortada, com erros de sintaxe, e com algumas parafasias fonêmicas. Posteriormente, tornou-se mais distante dos filhos e ficava irritada facilmente com 
enteado que tem retardo mental (o que foi uma mudança em relação ao seu comportamento pré-mórbido). Seus hábitos alimentares mudaram, e começou a comer mais (jantando até três vezes na mesma noite), o que levou a ganho de cerca de $10 \mathrm{~kg}$. Progressivamente sua fala tornou-se mais pobre e ela se tornou mais dependente para algumas atividades básicas de vida diária, como o banho. No início de 2012, a sua pontuação no MEEM foi de 11. A ressonância magnética de encéfalo feita em 2012 demonstrava atrofia cortical mais significativa em regiões frontais, com preservação relativa das porções mesiais dos lobos temporais. A atrofia frontal incluía a região orbitofrontal e se estendia para porções altas dos lobos parietais. A cintilografia de perfusão cerebral mostrava hipoperfusão frontal, temporo-parietal bilateral (maior a direita), e de núcleos da base.

Em 2013 apresentava redução importante da fala, que era limitada a palavras isoladas que eram ditas esporadicamente. Precisava de auxílio para realizar atividades básicas de vida diária, como alimentação e evoluiu com incontinência esfincteriana. Ao exame neurológico apresentava rigidez e bradcinesia (talvez relacionada ao uso de neurolépticos).

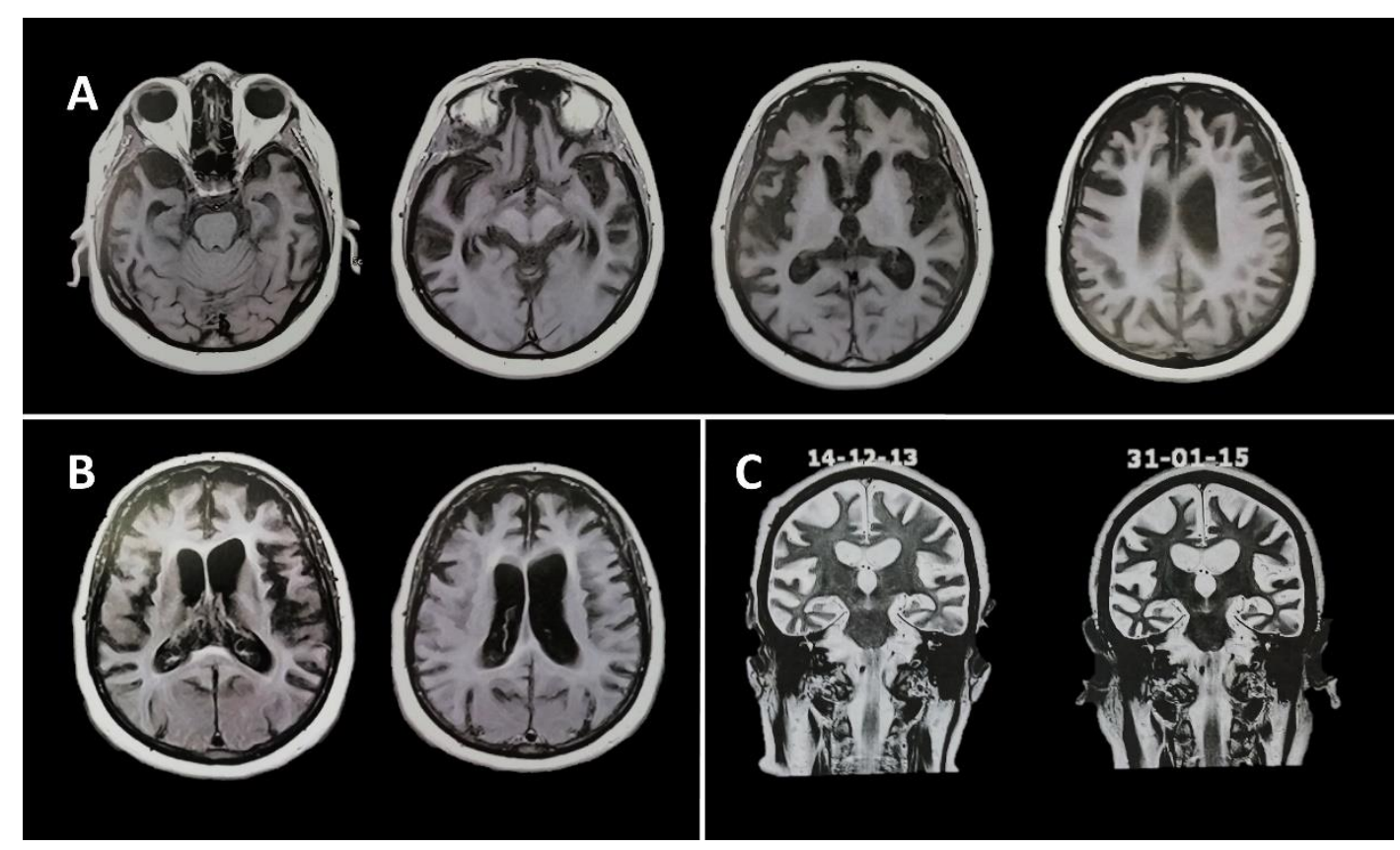

Figura 15 - Neuroimagem do probando DFT 58

Legenda: Ressonância magnética de encéfalo realizada seis anos após o início dos sintomas: (A) Cortes axiais de sequência ponderada em T1 mostrando redução volumétrica do encéfalo, com predomínio em lobos frontais e temporais. (B) Cortes axiais de sequência FLAIR que mostra hiperssinal discreto na substância branca periventricular. 
O hiperssinal é mais evidente nas regiões de maior atrofia. (C) Cortes coronais de sequência ponderada em T2 comparando imagens realizadas em 2013 (a esquerda) e 2015 (a direita). Nota-se aumento do volume ventricular entre as imagens e aumento de sulcos e fissuras, denotando redução volumétrica do encéfalo.

A irmã mais velha da paciente (III-1, Figura 14) foi diagnosticada com vcDFT, e o início de seus sintomas ocorreu aos 54 anos de idade, em 2008. Iniciou com dificuldade para realizar tarefas no trabalho que exigiam planejamento e organização. Evoluiu com mudança de hábitos alimentares (aumento de ingesta), ansiedade e compras excessivas.

No MEEM sua pontuação foi de 19 na avaliação inicial. ${ }^{341}$ Perdeu quatro pontos em orientação temporal, um ponto em orientação espacial, quatro pontos em cálculo, um ponto em evocação e um ponto na cópia do desenho. A fluência verbal semântica (categoria animais) foi de sete e fluência verbal fonêmica (letra F), de quatro. Na BBRC sua evocação tardia foi de seis itens e reconhecimento de 10 itens. ${ }^{343}$ Os demais itens do exame neurológico eram normais. A neuroimagem estrutural evidenciava atrofia de lobos frontais, bilateralmente (Figura 16) e a cintilografia de perfusão cerebral mostrava hipoperfusão frontotemporal bilateral.

Cerca de dois anos após início dos sintomas começou a ter dificuldade de reconhecer familiares e a ter delírios (achava que havia pessoas em casa). Tornou-se dependente para banho e escovar os dentes, e começou a apresentar incontinência esfincteriana. Ao exame neurológico apresentava sinais parkinsonianos (estava em uso de olanzapina). Sua pontuação no MEEM foi de 8. 


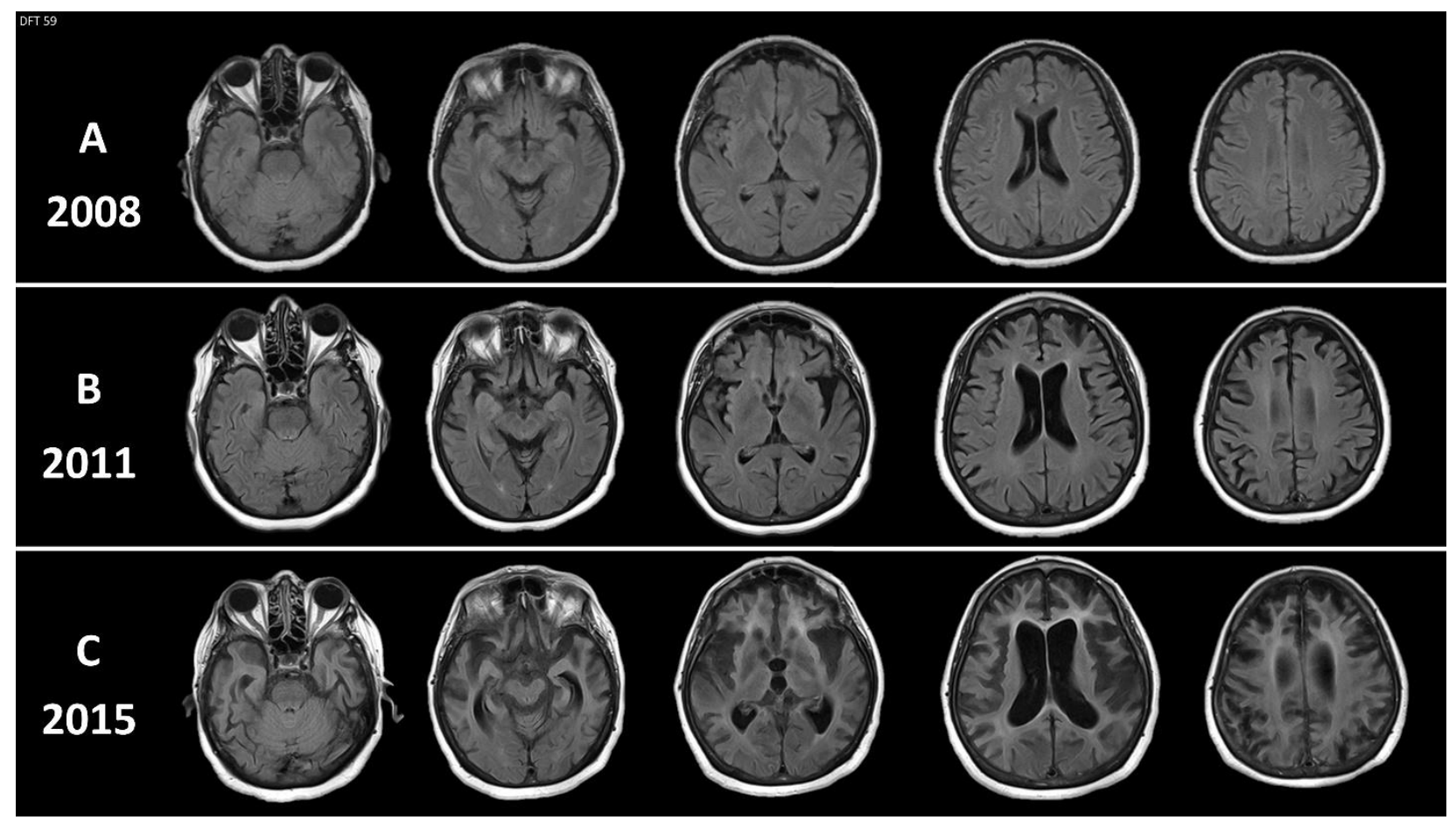

Figura 16 - Neuroimagem da irmã do probando DFT 58

Legenda: Ressonância magnética de encéfalo, cortes axiais de sequência FLAIR realizados em 2008 (A), 2011 (B), e 2015 (C). Pode-se observar atrofia progressiva, particularmente dos lobos frontais e temporais, evidenciada por alargamento de sulcos e fissuras nessas regiões. Nota-se também o aparecimento progressivo de hiperintensidades na substância branca dos hemisférios cerebrais, mais evidentes nas regiões de maior atrofia.

\subsubsection{Probando DFT 63: GRN p.D317Afs ${ }^{\star 11}$}

O sequenciamento do gene GRN revelou uma mutação g.1144411445delAC/p.D317Afs*11 no éxon 10 do gene (Figura 17). 

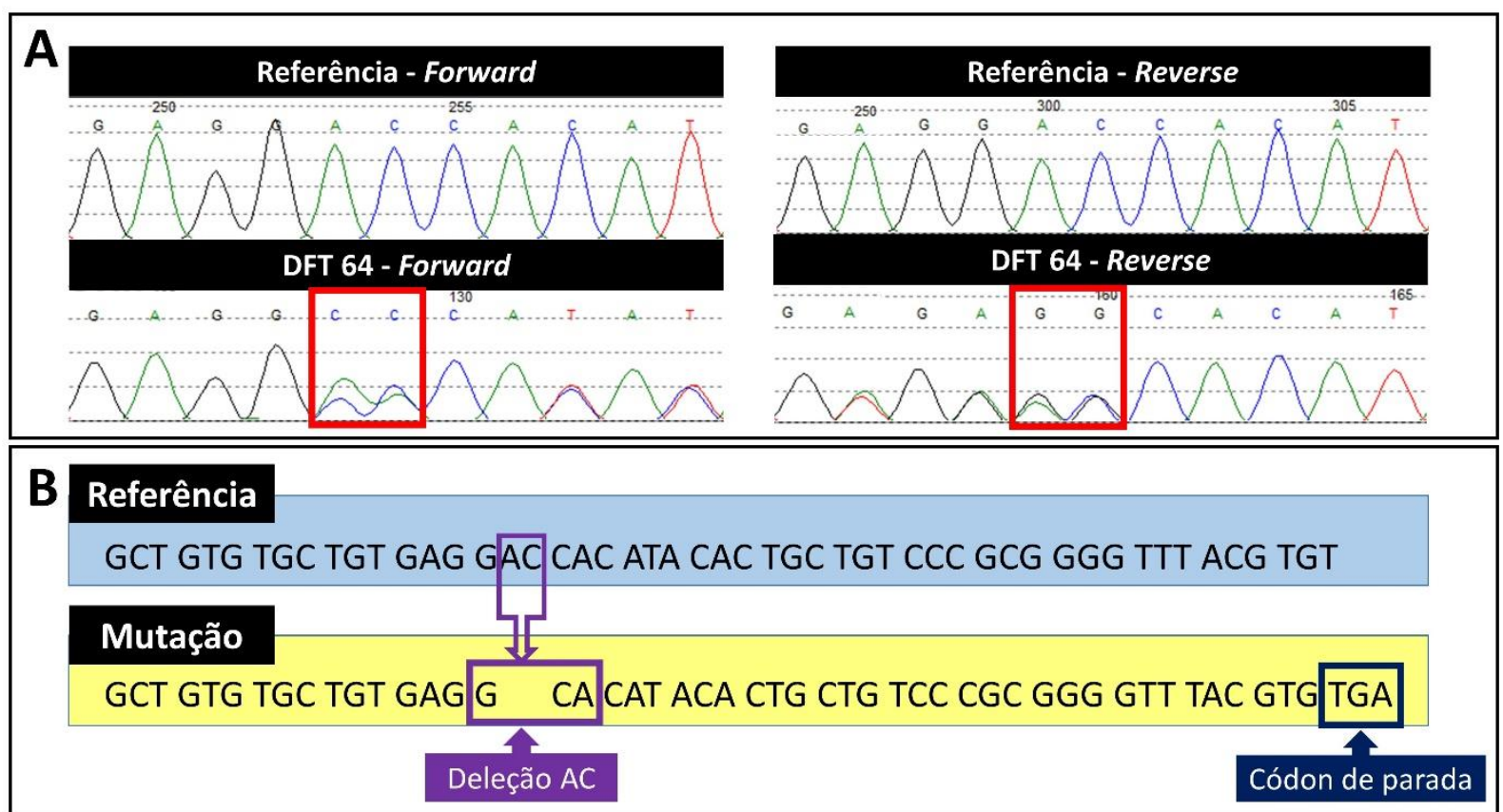

Figura 17 - Mutação GRN p.D317Afs*11

Legenda: (A) Cromatograma mostrando a mutação GRN g.11444-11445delAC (em vermelho); (B) Esquema que mostra posição da deleção, no éxon 10. A deleção leva a ocorrência de um códon de parada precoce (em azul).

Paciente do sexo masculino começou a apresentar sintomas cognitivos e comportamentais por volta dos 52 anos. A escolaridade do paciente era de 17 anos. Nessa época, o paciente deixou sua esposa e passou a viver com um garoto de programa, com quem gastava muito dinheiro. Além disso, tornou-se apático, impulsivo, e facilmente irritável. Posteriormente sua irmã descobriu que ele tinha vários cheques protestados, quando o gerente do banco ligou para ela. Devido a esses sintomas parou de trabalhar. Do ponto de vista cognitivo, queixava-se de esquecimento e dificuldade de concentração.

Foi avaliado pela primeira vez aos 54 anos, e na avaliação obteve 29 pontos no $\mathrm{MEEM}^{341}$ e sua fluência verbal semântica (para animais) foi de 14 . Ao exame encontrava-se inquieto, mas não foram notados sintomas motores. A avaliação neuropsicológica mostrou sinais de comprometimento dos lobos frontais, com dificuldades no planejamento, inflexibilidade mental e impulsividade, mas com memória episódica relativamente preservada. 
A ressonância magnética de encéfalo realizada aos 54 anos mostrava atrofia de predomínio nas regiões frontais, predominantemente a direita. A cintilografia de perfusão cerebral mostrava hipoperfusão frontal bilateral. Esse conjunto de achados, juntamente com o quadro clínico, levou a um diagnóstico de vcDFT.
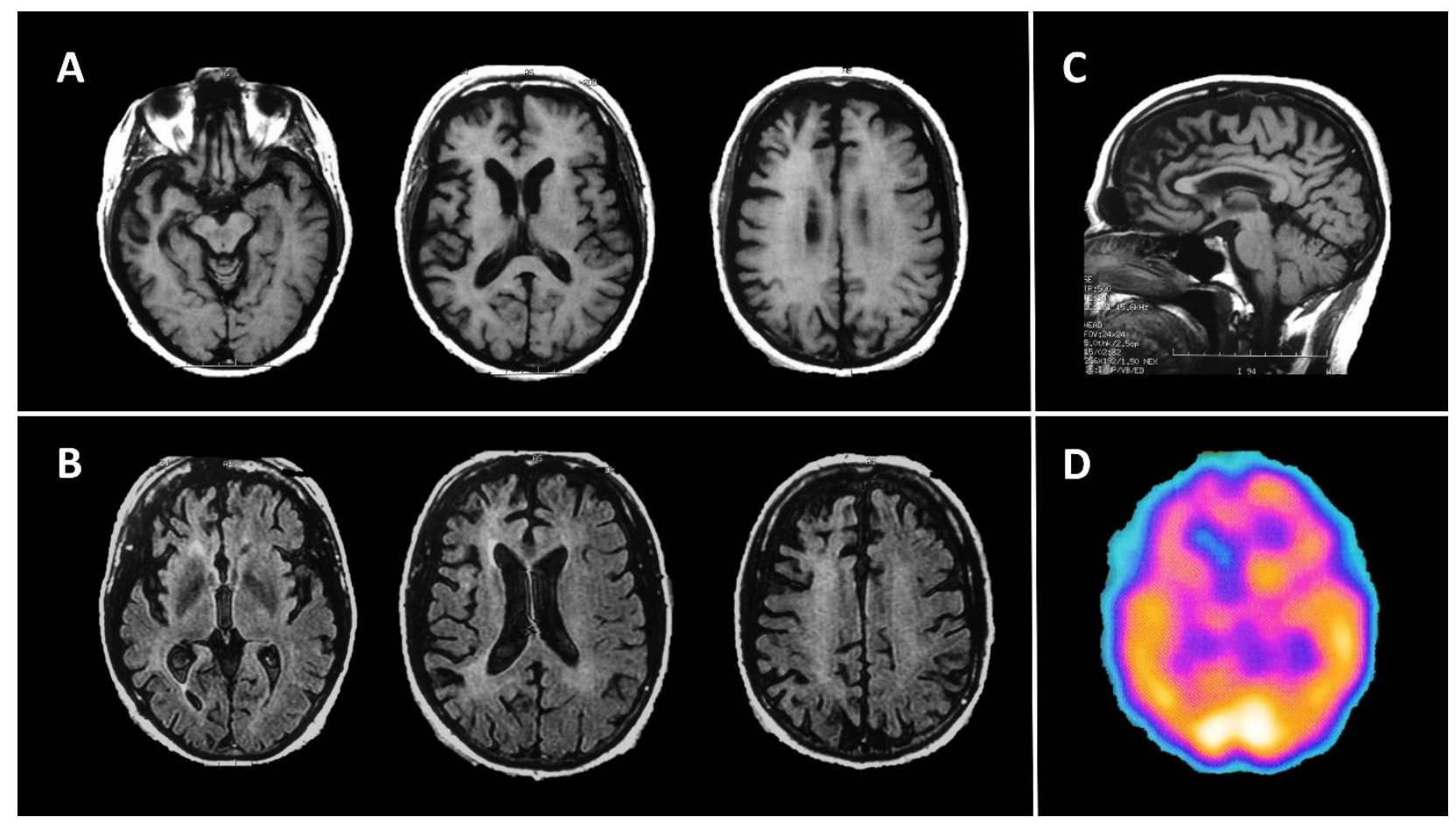

Figura 18 - Neuroimagem do probando DFT 63

Legenda: (A) Cortes axiais de ressonância magnética de encéfalo, sequencia pesada em T1. As imagens mostram alargamento difuso de sulcos e fissuras, que predominava a direita e nos lobos frontais e temporais. (B) Cortes axiais de sequência FLAIR de ressonância magnética de encéfalo mostrando hiperssinal em substância branca periventricular. (C) Corte sagital de ressonância magnética de encéfalo mostrando que o alargamento de sulcos predominava nas regiões anteriores do cérebro. (D) Cintilografia de perfusão cerebral que mostra hipoperfusão dos lobos frontais, predominando do lado direito do cérebro.

Os sintomas progrediram rapidamente, e aos 56 anos, o paciente já apresentava ecolalia (com produção verbal espontânea muito limitada) e reflexo de preensão palmar (grasping) bilateral. Posteriormente, ele desenvolveu sinais parkinsonianos e distonia em membros. O paciente faleceu aos 67 anos, cerca de 15 anos após o início dos sintomas.

O encéfalo do probando DFT 63 pesava 802 gramas, e na avaliação macroscópica observou-se sinais de atrofia cerebral com alargamento difuso dos 
sulcos e fissuras e aumento do volume dos ventrículos laterais, notadamente nos lobos frontais, parietais e temporais (Figura 19). A atrofia era um pouco mais evidente a direita. Ao exame microscópico, observou-se várias inclusões intracitoplasmáticas imunorreativas a anticorpos contra TDP-43 hiperfosforilada e neuritos curtos, em padrão compatível com patologia DLFT-TDP tipo A. ${ }^{44}$
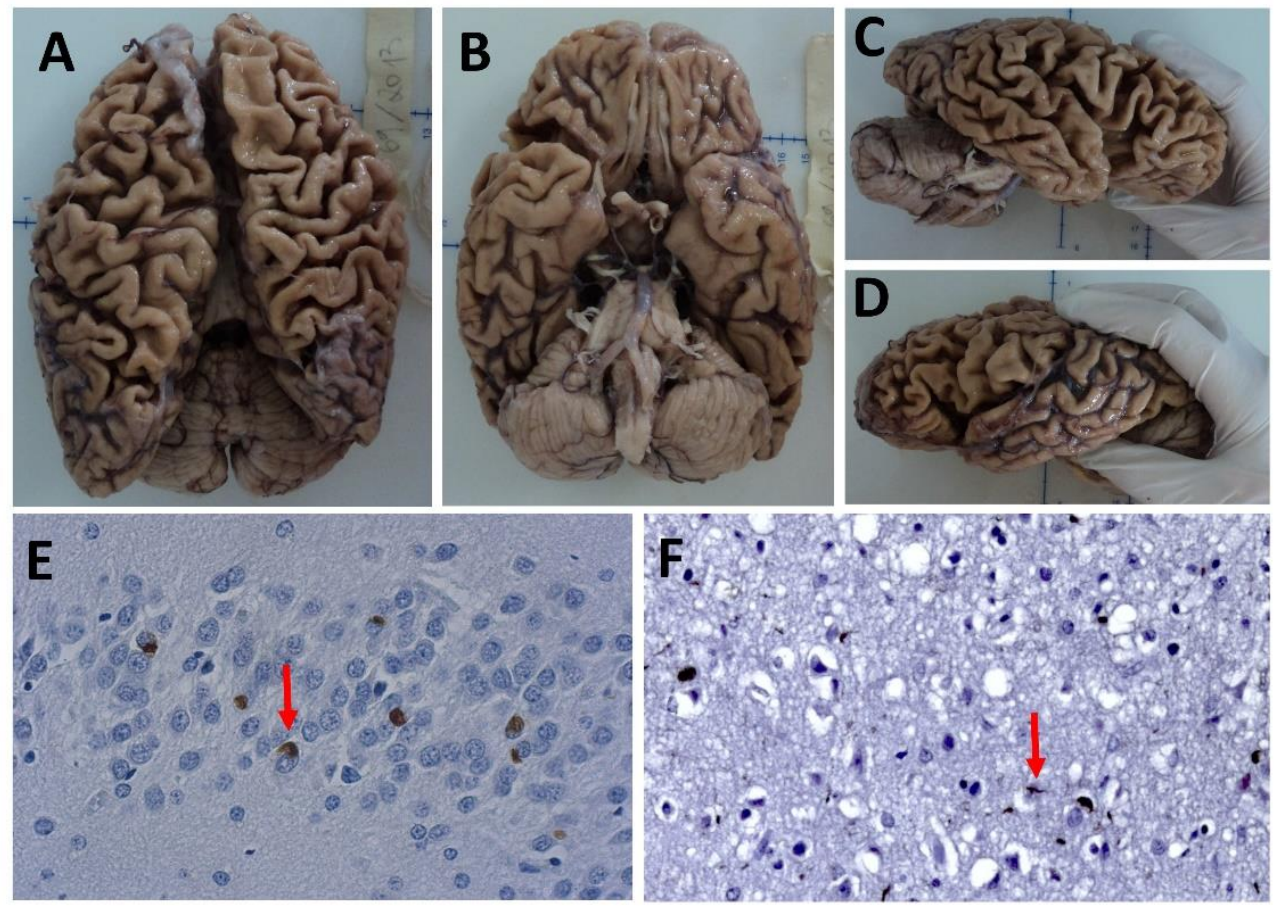

Figura 19 - Estudo neuropatológico do probando DFT 63

Legenda: A avaliação macroscópia do encéfalo demonstra uma atrofia cortical global com envolvimento maior dos lobos frontal, temporal e parietal. Nota-se uma atrofia assimétrica, com maior envolvimento do hemisfério direito (A: visão dorsal; B: visão ventral; C: visão lateral do hemisfério direito; $\mathrm{D}$ : visão lateral do hemisfério esquerdo). Alterações histopatológicas na imuno-histoquímica utilizando anticorpo contra TDP-43 hiperfosforilada: (E) Inclusões neuronais citoplasmáticas na camada granular da fáscia denteada (seta vermelha); (F) Neurito distrófico curto (seta vermelha) no córtex entorrinal. Aumento: E, F- 400X.

A história familiar inicialmente era negativa para DFT, mas a mãe do probando (II-1, Figura 20) desenvolveu um quadro demencial alguns anos após o início dos sintomas dele. A avó materna do probando (I-1) foi diagnosticada com DA e faleceu após os 70 anos de idade. Ela era de origem polonesa. Um irmão do probando (III-3) faleceu aos 30 anos em um acidente de trânsito. 


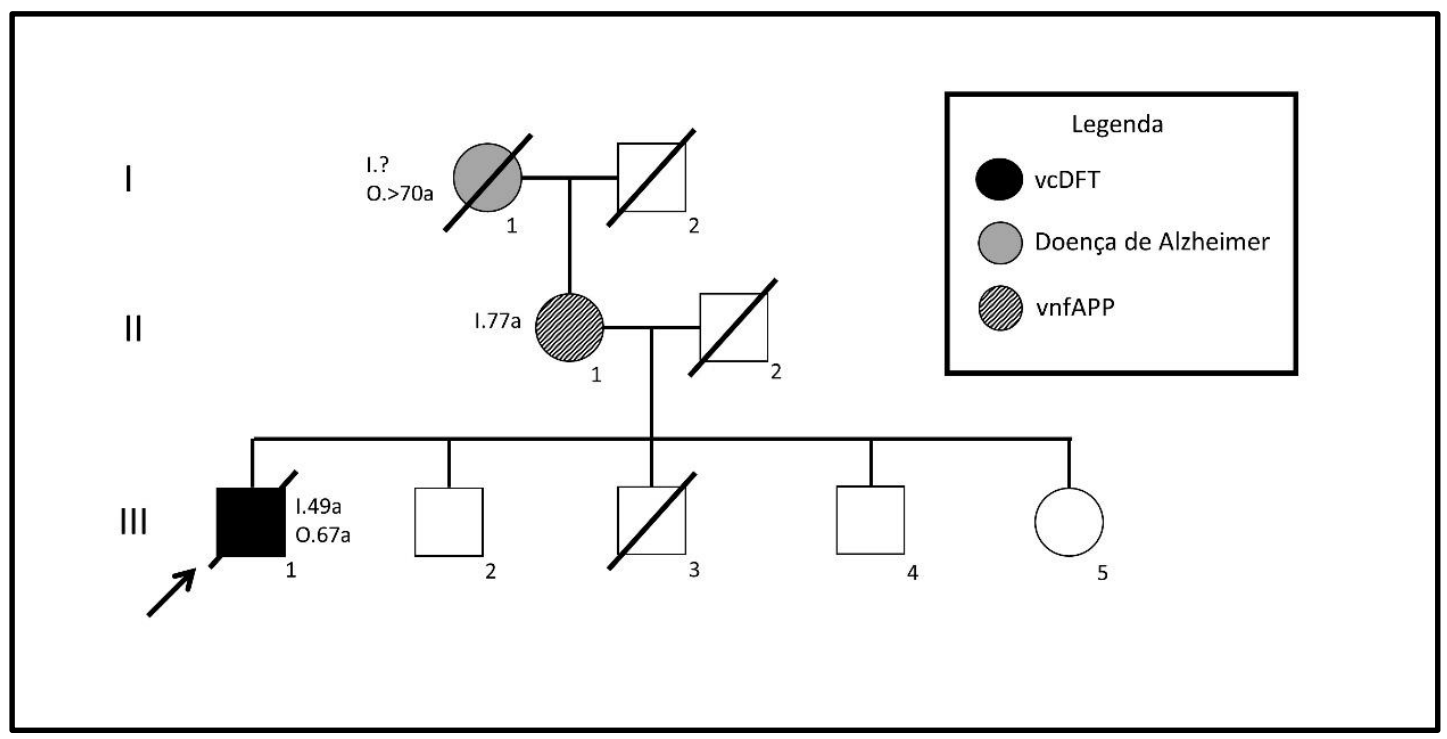

Figura 20 - Heredograma da família do probando DFT 63

Legenda: A seta indica o probando. Círculos representam mulheres e quadrados representam homens. A linha diagonal indica que o indivíduo já faleceu. I= idade de início dos sintomas. $\mathrm{O}=$ idade de óbito.

A paciente II-1 (Figura 20) é destra, completou o ensino superior, e atualmente tem 89 anos. Por volta dos 77 anos de idade (em 2003), ela começou a se queixar de dificuldades na fala, caracterizadas por trocas de palavras, trocas e omissões de fonemas e de plurais. Também notou dificuldades similares na escrita. Seus familiares também notaram que ela precisava de mais tempo e de repetições para compreender assuntos nas conversas. Apesar dessas dificuldades, no início do quadro a paciente ainda mantinha a independência funcional. Ela participava das decisões na empresa da família e cuidava do filho. Não foram notadas mudanças comportamentais no início do quadro. Uma avaliação neuropsicológica realizada cerca de um ano após o início dos sintomas revelou dificuldades significativas em processos atencionais e de funções executivas, além de discretas alterações na linguagem expressiva. Memória, habilidades visuoespaciais, sensoriomotoras, grafomotoras, e compreensão linguística encontravam-se preservadas.

Sintomas comportamentais apareceram cerca de dois anos após o início dos sintomas, e foram notados quando seu marido morreu e sua filha notou que ela não pareceu abalada. Parecia também distante dos familiares, e começou a ter atitudes atípicas, como comprar roupas que não eram de seu gosto usual, ou então querer 
guardar assentos ao embarcar em um avião. Posteriormente foi se tornando cada vez mais apática e começou a ter dificuldade para caminhar. Em 2008, a paciente apresentava marcha a pequenos passos e rigidez com roda denteada bilateralmente, além de grasping bilateral. Sua expressão era limitada a sons ininteligíveis, mas parecia reconhecer as pessoas. Os exames de neuroimagem mostravam atrofia global, com predomínio nos lobos frontais e à esquerda (Figura 21). A paciente então recebeu diagnóstico de vnfAPP, que posteriormente evoluiu com sintomas comportamentais como os observados na vcDFT, e parkinsonismo.

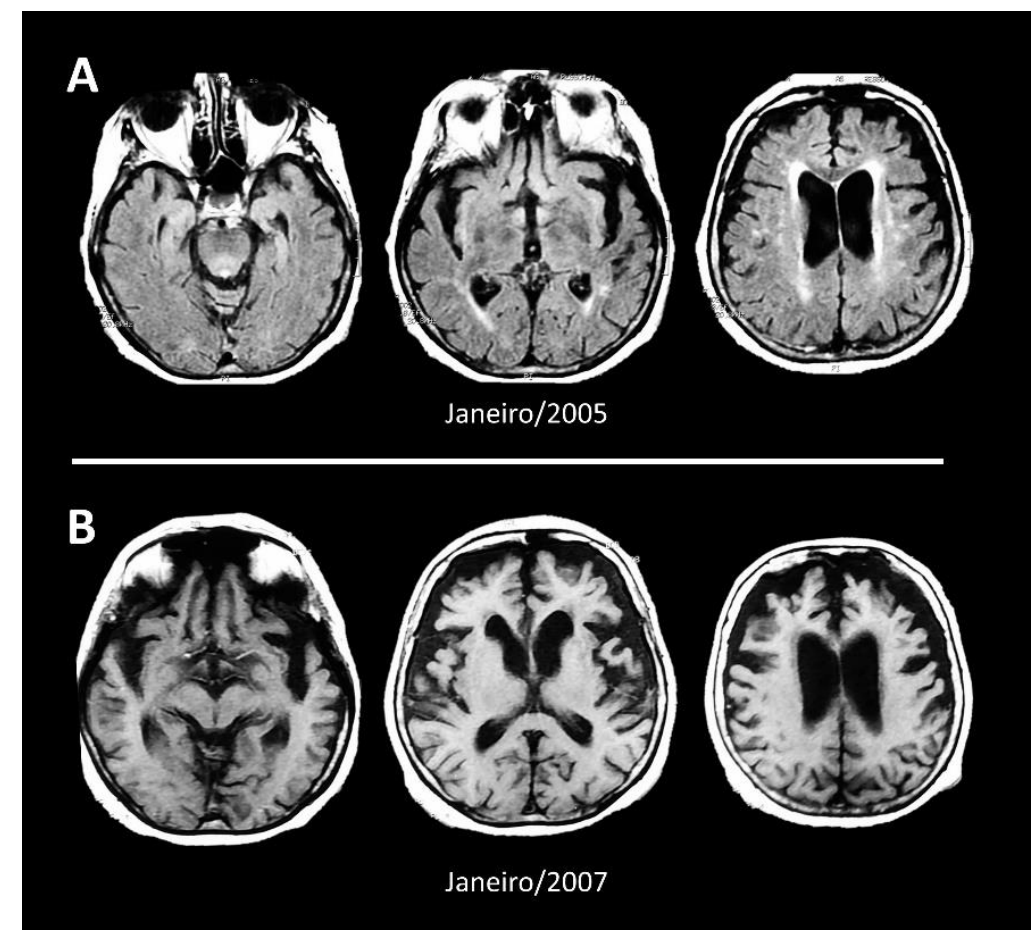

Figura 21 - Neuroimagem da mãe do probando DFT 63

Legenda: $(A)$ Cortes axiais de sequência FLAIR de ressonância magnética de encéfalo realizada em janeiro de 2005 que mostram aumento de sulcos em regiões frontais dorsolaterais, mediais e orbitofrontais, mais evidentes do lado esquerdo. À esquerda se observa também aumento de sulcos em lobo parietal e temporal posterior. Observa-se também hipersinal na substância branca hemisférica, particularmente periventricular. (B) Cortes axiais de sequência ponderada em T1 de ressonância magnética de encéfalo realizada em janeiro de 2007 , mostrando progressão da atrofia notada nas imagens de dois anos antes.

O quadro foi progredindo lentamente e cerca de oito anos após o início dos sintomas, a paciente estava em mutismo e não era mais capaz de deambular. Há 
cerca de dois anos, foi submetida a colocação de gastrostomia. Foi reavaliada em agosto de 2014. Naquela ocasião, a paciente se encontrava em mutismo e não mantinha contato visual ou verbal. Tinha hipertonia nos quatro membros, que lembrava mais espasticidade, apesar de apresentar reflexos globalmente hipoativos e de a resposta do reflexo cutâneoplantar ser em flexão. O sequenciamento do gene da progranulina revelou a mesma mutação que fora encontrada em seu filho.

\subsubsection{Probando DFT 64: GRN p.S301Cfs ${ }^{\star} 60$}

O sequenciamento do éxon 9 do probando DFT 64 revelou uma inserção de GT nas posições 11307 e 11308 (GRN g.11307-11308dupGT). Essa inserção leva a uma mutação frameshift, com formação de códon de parada precoce no éxon 10 (Figura 22). A mutação também pode ser denominada de GRN p.S301Cfs*60.

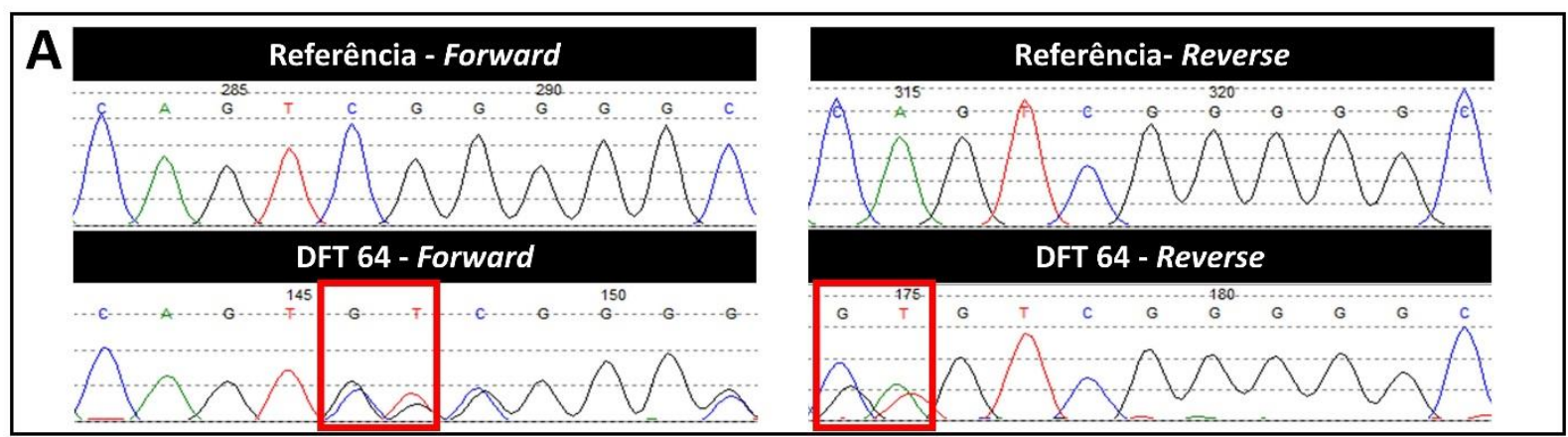

B Referência

CAG TCG GGG GCC TGG GGC TGC TGC CCT TTT ACC CAG (intron) GCT GTG TGC TGT GAG GAC CAC ATA CAC [...] GCT CAC CTC AGC CTG CCA GAC CCA CAA GCC TTG AAG

Mutação Inserção $\mathrm{GT}$

CAG TGT tGG GGG CCT GGG GCT GCT GCC CTT TTA CCC AGG (intron) CTG TGT GCT GTG AGG ACC ACA TAC ACT [...] CTC ACC TCA GCC TGC CAG ACC CAC AAG CCT TGA

Códon de parada

Figura 22 - Mutação GRN p.S301Cfs*60

Legenda: (A) Cromatograma mostrando a mutação GRN g.11307-11308dupGT (em vermelho);

(B) Esquema que mostra posição da inserção, no éxon 9. A inserção leva a ocorrência de um códon de parada precoce no éxon 10 (em azul). 
O probando DFT 64 é um paciente do sexo masculino, com ensino superior completo, que foi avaliado pela primeira vez em dezembro de 2013, quando tinha 44 anos. Em julho de 2013, após sua filha resolver voltar a morar com a mãe (e ex-esposa do paciente), ele começou a se isolar, não respondendo ligações. Nessa época, seus amigos começaram a estranhar seu comportamento. Ele abandonou seus empregos, alegando não ter mais paciência para mantê-los. Posteriormente, sua irmã descobriu que havia sido aberto um processo administrativo por má conduta profissional contra ele, pois começou a sair no meio das aulas sem motivo aparente, além de discutir com alunos e funcionários.

Em novembro de 2013, ele foi morar com sua irmã e seu cunhado. Sua irmã notou que a casa em que ele morava estava suja, com roupas mofadas e alimentos deteriorados. Ela também descobriu que ele passou o carro a um mecânico, sem cobrar nenhum valor. Nessa época, sua irmã começou a notar dificuldades cognitivas, como dificuldade para contar histórias, esquecimento de fatos recentes (como se havia tomado determinada medicação), e repetitividade. Posteriormente, desenvolveu alterações comportamentais como comportamento infantil (passou a dizer coisas como "as plantinhas estão felizes") e rigidez (esperava o cunhado todos os dias para cuidar do gato, ou então ficava ansioso com os horários das refeições). Também tinha comportamentos que sugeriam perda de capacidade de julgamento, como usar cueca suja, ou colocar duas cuecas ao mesmo tempo, ou ainda perguntar se sua mãe não iria receber "alta" da instituição de longa permanência. Ele sempre havia sido responsável com finanças, mas começou a contrair dívidas com o banco, e a deixar de pagar contas. Em alguns momentos, ele tinha dificuldade para escrever (as palavras saiam com letras faltando), e se esquecia de senhas de banco. Quando ele se lembrava das senhas, dizia em voz alta no banco, sem se importar com as outras pessoas ao redor.

Mesmo na casa da irmã ele continuou isolado, ficando "trancado" dentro de casa de novembro de 2013 a abril de 2014, e só aceitava sair com a irmã e o cunhado. A irmã do paciente também notou que ele não se importava em ficar hospedado na casa dela e não auxiliar nas despesas.

Na primeira avaliação, dezembro de 2013 , sua pontuação no $\mathrm{MEEM}^{341}$ foi de 23. Ele perdeu dois pontos em orientação temporal, quatro pontos em cálculo, dois pontos na evocação, e um ponto na cópia dos pentágonos. A pontuação no teste de 
ordem de dígitos direta foi de quatro, e na ordem inversa, de dois. $\mathrm{Na} B B R C,{ }^{343}$ a nomeação e percepção das figuras foi de 10 em 10. Nas etapas de memória incidental, memória imediata e aprendizado, sua pontuação foi de 5, 7 e 7, respectivamente. $\mathrm{Na}$ memória tardia, o paciente se lembrou de nove itens e reconheceu corretamente nove itens. A fluência verbal semântica foi de 17 animais e a fonêmica foi de oito palavras que começavam com P. Sua pontuação no teste do desenho do relógio ${ }^{344}$ foi de dois, por ter apenas desenhado um círculo e dois ponteiros. O restante do exame neurológico era normal, e o paciente não apresentava sinais de parkinsonismo ou de DNM.

Sete meses depois, ele foi incapaz de escrever uma frase e no teste desenho do relógio, foi incapaz de desenhar espontaneamente. A examinadora então desenhou um círculo e os números 3, 6, 9 e 12 e pediu para o paciente desenhar o restante. Ele apenas interligou os números com duas linhas perpendiculares.

O quadro cognitivo e comportamental foi piorando progressivamente, e o paciente foi institucionalizado em novembro de 2014. A fala foi reduzindo progressivamente, e atualmente o paciente está em mutismo; tampouco consegue compreender ordens verbais. Ele apresenta episódios de agitação e agressividade, motivo pelo qual está em uso de trazodona e quetiapina. Ele está dependente para atividades básicas de vida diária como tomar banho ou se vestir; também necessita de fraldas por incontinência esfincteriana. E mais recentemente sua marcha tornouse mais lenta.

A ressonância magnética de encéfalo de janeiro de 2014 mostrava aumento difuso de sulcos e fissuras cerebrais, com discreto predomínio frontal (Figura 23). A cintilografia de perfusão cerebral realizada em fevereiro de 2014 mostrava déficit perfusional que predominava nos lobos frontais e nas porções anteriores dos lobos parietais. 

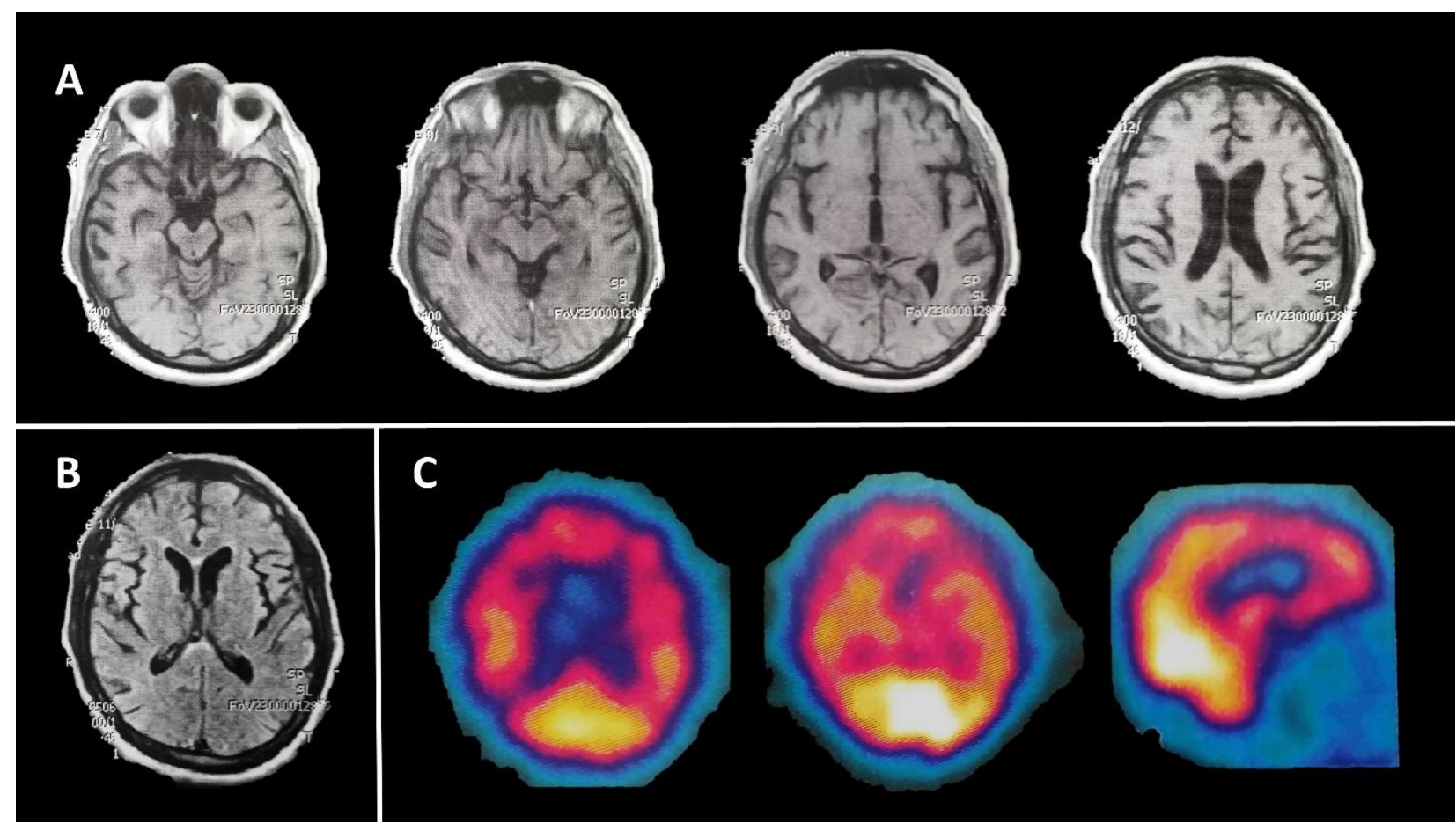

Figura 23 - Neuroimagem do probando DFT 64

Legenda: Ressonância magnética de encéfalo (A) Cortes axiais de sequência ponderada em T1 que mostram aumento difuso de sulcos e fissuras corticais, com discreto predomínio em regiões frontais e (B) Corte axial de sequência FLAIR demonstrando ausência de alterações significativas na substância branca. (C) Cintilografia de perfusão cerebral (cortes axiais e sagital) mostrando hipofluxo nas regiões frontais e parietais, além de hipofluxo menos evidente na região temporal direita.

Com os dados clínicos e de neuroimagem, foi feita hipótese diagnóstica de vcDFT provável. A mãe do paciente já havia sido diagnosticada com vcDFT, e o heredograma da família do probando DFT 64 mostra um padrão de herança autossômico dominante, mas possivelmente com penetrância incompleta (Figura 24). A mãe do paciente DFT 64 (II-9, na figura 24) foi diagnosticada com vcDFT. O início dos sintomas ocorreu aos 58 anos, e ela faleceu em 2014, aos 69 anos. O avô materno do probando (I-2) era de origem portuguesa e desenvolveu quadro demencial de início na sétima década de vida e foi a óbito por volta dos 70 a 75 anos (após cerca de oito anos de doença). E um tio materno (II-4) do probando apresentou declínio cognitivo por volta dos 59 anos, e faleceu aos 68 anos com diagnóstico de DA. Um primo materno do probando (III-1) foi diagnosticado com vcDFT. O início dos sintomas ocorreu aos 59 anos, e óbito, aos 70 anos de idade. A mãe desse primo (II-3) faleceu 
por causas clínicas (não neurológicas) aos 87 anos de idade, sem quadro demencial evidente.

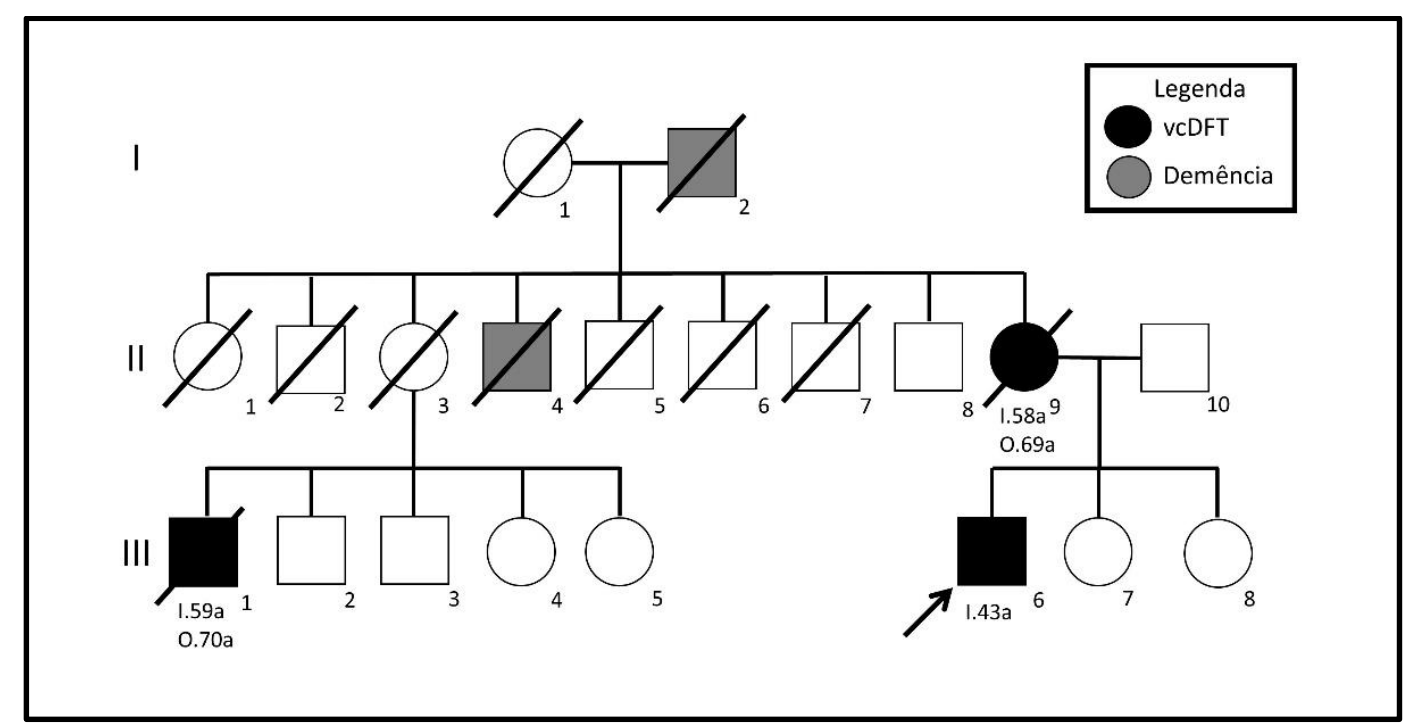

Figura 24 - Heredograma da família do probando DFT 64

Legenda: A seta indica o probando. Círculos representam mulheres e quadrados representam homens. A linha diagonal indica que o indivíduo já faleceu. $\mathrm{l}=\mathrm{idade}$ de início dos sintomas. $\mathrm{O}=$ idade de óbito.

\subsection{Mutações patogênicas encontrada em MAPT}

\subsubsection{Probando DFT 17: MAPT p.N279K}

O sequenciamento de MAPT do probando DFT mostrou uma substituição de timina por guanina (MAPT g.120904T>G), que leva a troca de uma asparagina (AAT) por lisina (AAG) na posição 279 (MAPT p.N279K) (Figura 25). Esta mutação missense se refere ao alelo menor do SNP rs63750756. 


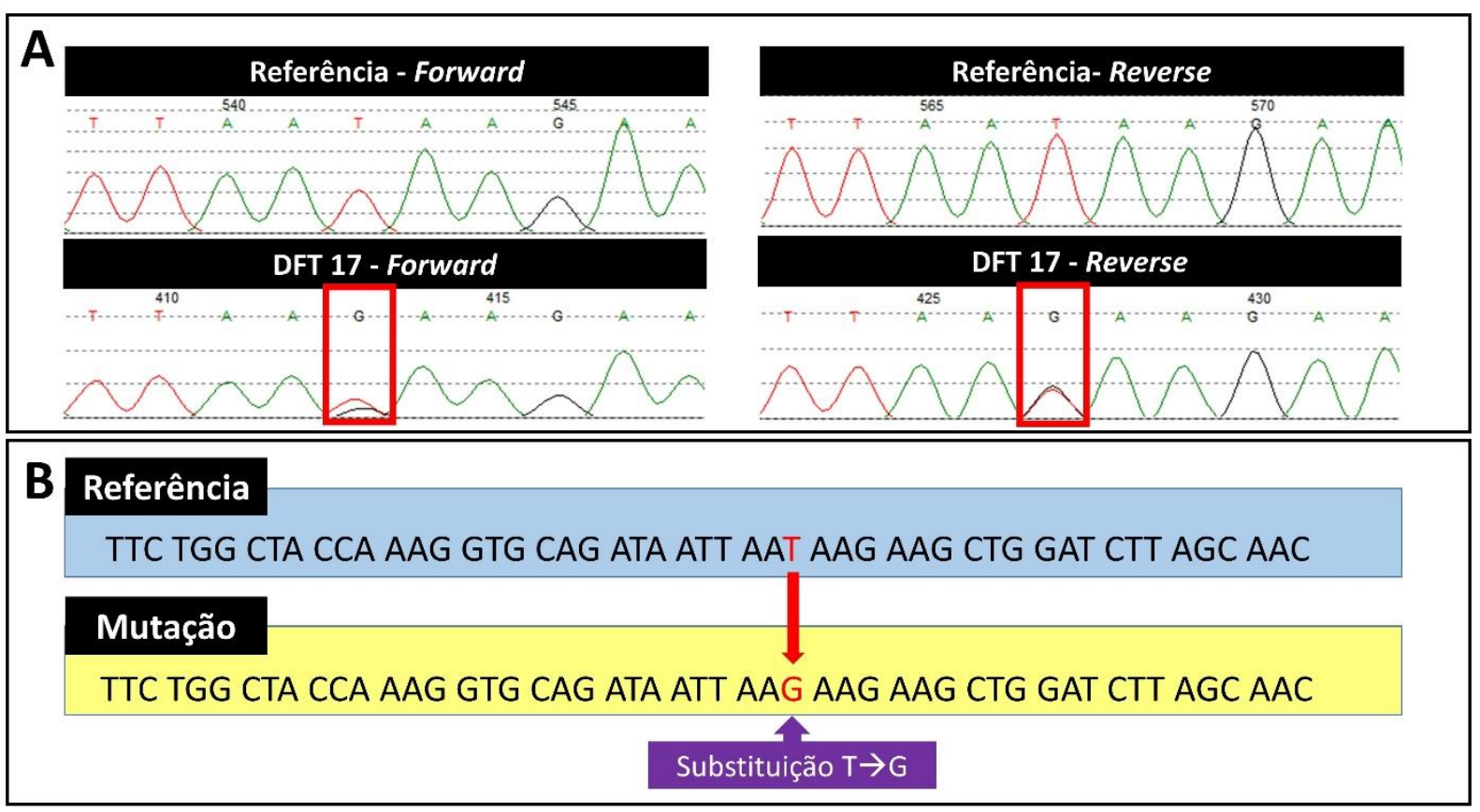

Figura 25 - Mutação MAPT p.N279K

Legenda: (A) Cromatograma mostrando a mutação MAPT g.120904T>G (em vermelho); (B) Esquema que mostra posição da mutação, no éxon 10. A troca de base leva a substituição de asparagina (AAT) por lisina (AAG) na posição 279 da proteína tau.

O probando DFT 17 era do sexo masculino, tinha completado o ensino superior, e foi avaliado pela primeira vez no ambulatório do GNCC-HCFMUSP em dezembro de 2010, quando tinha 47 anos. O início dos sintomas ocorreu aos 45 anos, e foi caracterizada inicialmente por apatia com diminuição da iniciativa, associada a diminuição progressiva da fala espontânea e alentecimento psicomotor. Na mesma época, o paciente também desenvolveu sintomas motores como tremores em membros superiores e desequilíbrio, além de algumas quedas para trás. O paciente recebeu levodopa devido ao quadro parkinsoniano, e a esposa relatou alguma melhora dos sintomas motores. O paciente apresentava leve desinibição, com risadas inapropriadas, mas sua esposa negou alterações nos hábitos alimentares, comportamentos repetitivos ou ritualísticos, ou ainda inflexibilidade mental.

O paciente tinha diagnóstico de síndrome da imunodeficiência adquirida (SIDA) desde 2001, e usava terapia antirretroviral regularmente. Ele não tinha outras comorbidades. 
Ao exame neurológico, o paciente apresentava redução do balanço passivo de membros superiores durante a marcha, mas os passos eram de comprimento adequado e não havia sinais de instabilidade postural. A motricidade ocular extrínseca era normal, mas apresentava sinais de apraxia do fechamento ocular. Ele também apresentava tremor de repouso que era pior no hemicorpo direito, associado a rigidez com roda denteada e bradcinesia nos quatro membros.

Sua pontuação no $\mathrm{MEEM}^{341}$ foi de 24 pontos, tendo perdido um ponto em orientação temporal, um ponto em orientação espacial, três pontos em cálculo, e um ponto na evocação. A pontuação na ordem de dígitos direta foi de quatro, e na ordem inversa, foi de dois. $\mathrm{Na} B B R C,{ }^{343}$ o paciente percebeu e nomeou as dez figuras corretamente. Suas pontuações nas etapas de memória incidental, memória imediata e aprendizado foram respectivamente de dois, quatro e cinco. O paciente recordou duas figuras espontaneamente (memória tardia), e reconheceu as dez figuras. No teste do desenho do relógio, ${ }^{344}$ sua pontuação foi de oito. A fluência verbal semântica foi de seis animais e a fonêmica foi de uma palavra que começava com a letra P. O sinal do aplauso ${ }^{349}$ foi positivo, pois o paciente bateu palmas quatro vezes ao invés das três que foi solicitado.

A tomografia computadorizada de crânio realizada em junho de 2010 mostrava atrofia nos lobos temporais mediais e anteriores, predominantemente a direita (Figura 26). A cintilografia de perfusão cerebral, realizada em março de 2011, mostrou discreto hipofluxo na região temporoparietal direita. 

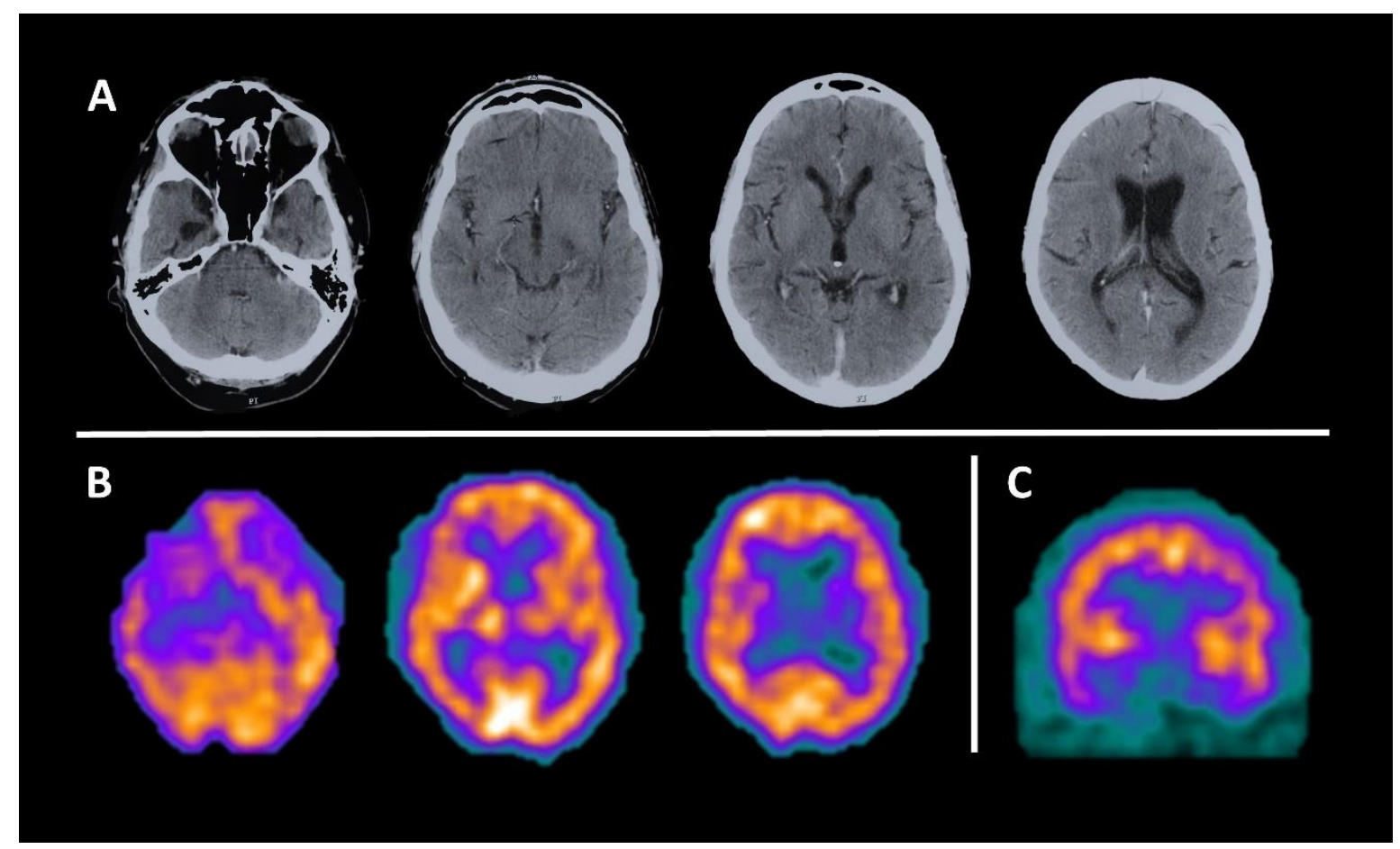

Figura 26 - Neuroimagem do probando DFT 17

Legenda: (A) Cortes axiais de tomografia computadorizada de crânio que mostram atrofia mais significativa em lobos temporais mediais, particularmente a direita. (B) Cortes axiais e (C) corte coronal de cintilografia de perfusão cerebral mostrando hipofluxo em região temporoparietal direita.

Com base no quadro clínico observado na primeira consulta e achados de neuroimagem, o diagnóstico inicial do paciente foi de vcDFT com parkinsonismo. No seguimento do paciente, o paciente evoluiu com piora no quadro cognitivo e motor. Em novembro de 2011 foram notadas alterações na motricidade ocular extrínseca, com paralisia do olhar vertical e lentificação das sacadas horizontais, além de rigidez axial e manutenção da apraxia para o fechamento ocular. Os sintomas parkinsonianos foram se tornando cada vez mais evidentes, com quedas mais frequentes, e com resposta cada vez mais pobre a levodopa. Devido ao aparecimento desses sintomas e sinais, o fenótipo do paciente tornou-se mais sugestivo de PSP.

Em março de 2014, o paciente já não conseguia mais ficar em pé, apresentava disfagia e necessitava de fraldas por incontinência esfincteriana. O paciente faleceu aos 51 anos, em janeiro de 2015, após seis anos de doença. Sua esposa informou que a causa de óbito constatada foi infarto agudo do miocárdio.

O paciente tinha SIDA como antecedente, o que inicialmente poderia ter levado a hipótese de que a infecção pelo vírus HIV poderia estar associada aos sintomas que 80 
o paciente apresentava. No entanto, ao se analisar a história familiar do probando, observamos um padrão de herança autossômico dominante (Figura 27). Nenhum dos irmãos foi avaliado em nosso serviço, mas a descrição dos sintomas sugeria sintomas comportamentais, associados a sintomas motores com parkinsonismo e distúrbio de marcha em um fenótipo que sugeria PSP com algumas características de vcDFT. O início dos sintomas nos irmãos do probando ocorreu entre 36 e 41 anos, e a duração da doença foi de 4 a 12 anos. O pai do probando (I-2, Figura 27) teve um quadro demencial que se iniciou aos 40 anos, e faleceu aos 51 anos. A filha do probando (III12) faleceu aos 15 anos de idade por um tumor primário de sistema nervoso central. Os demais indivíduos da geração III tem atualmente entre 19 e 36 anos, e não apresentam sintomas neurológicos. O indivíduo III-3 tem doença psiquiátrica que não foi bem caracterizada, e atualmente tem cerca de 36 anos.

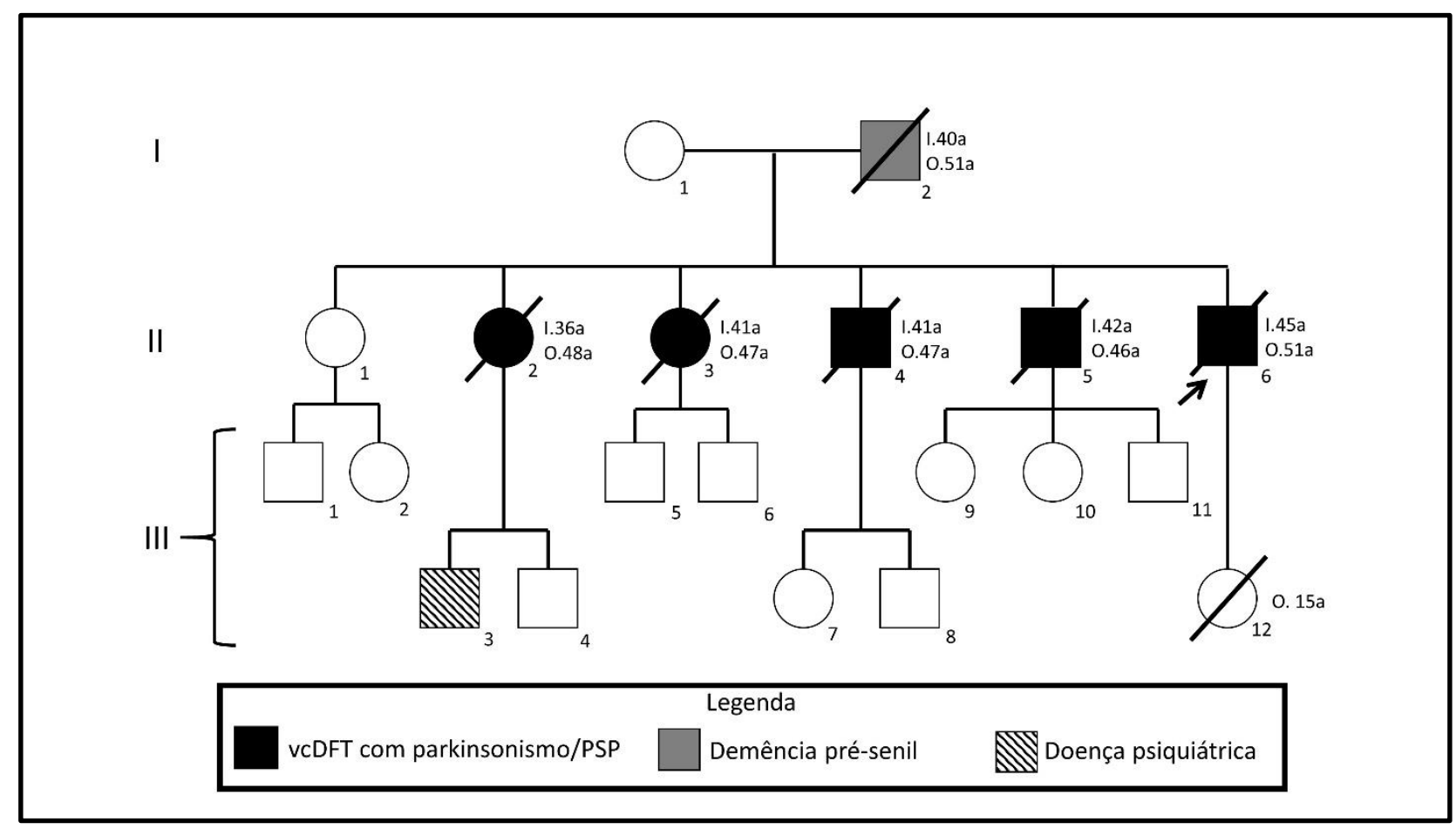

Figura 27 - Heredograma da família do probando DFT 17

Legenda: A seta indica o probando (III-1). Círculos representam mulheres e quadrados representam homens. A linha diagonal indica que o indivíduo já faleceu. $\mathrm{I}=$ idade de início dos sintomas. $\mathrm{O}=$ idade de óbito.

\subsection{Dosagem plasmática de progranulina}


Por motivos logísticos (já que a centrifugação do sangue para obtenção do plasma precisava ser feita no mesmo dia da coleta), não foi possível obter plasma de um probando com DFT sem mutação em $G R N$ e de outros dois probandos com mutação em GRN.

A dosagem de progranulina no plasma foi significativamente menor no grupo de pacientes com DFT e mutação em GRN do que no grupo de pacientes com DFT sem mutação em GRN ou no grupo controle ( $<<0,0001$ e $p=0,0001$, respectivamente), como mostra a Tabela 8 e Figura 28.

Nos pacientes com mutações nulas em GRN, o nível de progranulina plasmática variou entre 17,8 e $48,4 \mathrm{ng} / \mathrm{ml}$. O nível de progranulina plasmática no probando DFT 11 foi de $18,4 \mathrm{ng} / \mathrm{ml}$, no probando DFT 22 foi de $39,2 \mathrm{ng} / \mathrm{ml}$, no probando DFT 53 foi de $22,1 \mathrm{ng} / \mathrm{ml}$, e no probando DFT 64 foi de $17,8 \mathrm{ng} / \mathrm{ml}$. No irmão da paciente DFT 22 (III-2, Figura 9), o nível de progranulina plasmática foi de $37,8 \mathrm{ng} / \mathrm{ml}$.

Não foi possível obter plasma dos probandos DFT 58 e DFT 63. No entanto, foi possível colher plasma de familiares de primeiro grau desses probandos, nos quais mutações também foram identificadas. Na irmã do probando DFT 58 (III-1, Figura 14), o nível de progranulina foi de $25 \mathrm{ng} / \mathrm{ml}$. Na mãe do probando DFT 63 (II-1, Figura 20), o nível de progranulina foi de $48,4 \mathrm{ng} / \mathrm{ml}$.

No paciente com mutação em MAPT (DFT 17), o nível de progranulina no plasma foi de $178,5 \mathrm{ng} / \mathrm{ml}$.

A dosagem de progranulina no grupo controle foi maior do que no grupo de pacientes com DFT sem mutação em GRN ( $p<0,0001)$.

Tabela 9 - Médias e desvios-padrão da dosagem plasmática de progranulina

\begin{tabular}{lccc}
\hline Grupo & N & $\begin{array}{c}\text { Dosagem de progranulina no plasma } \\
\text { Média } \pm \text { Desvio Padrão (Variação) }\end{array}$ & p \\
\hline DFT com mutação em GRN & 7 & $29,8 \pm 11,9(17,8-48,4)$ & \\
DFT sem mutação em GRN & 55 & $109,0 \pm 30,7(70,2-206,3)$ & 0,0001 \\
Controle & 60 & $158,4 \pm 32,0(94,8-249,9)$ & \\
\hline
\end{tabular}




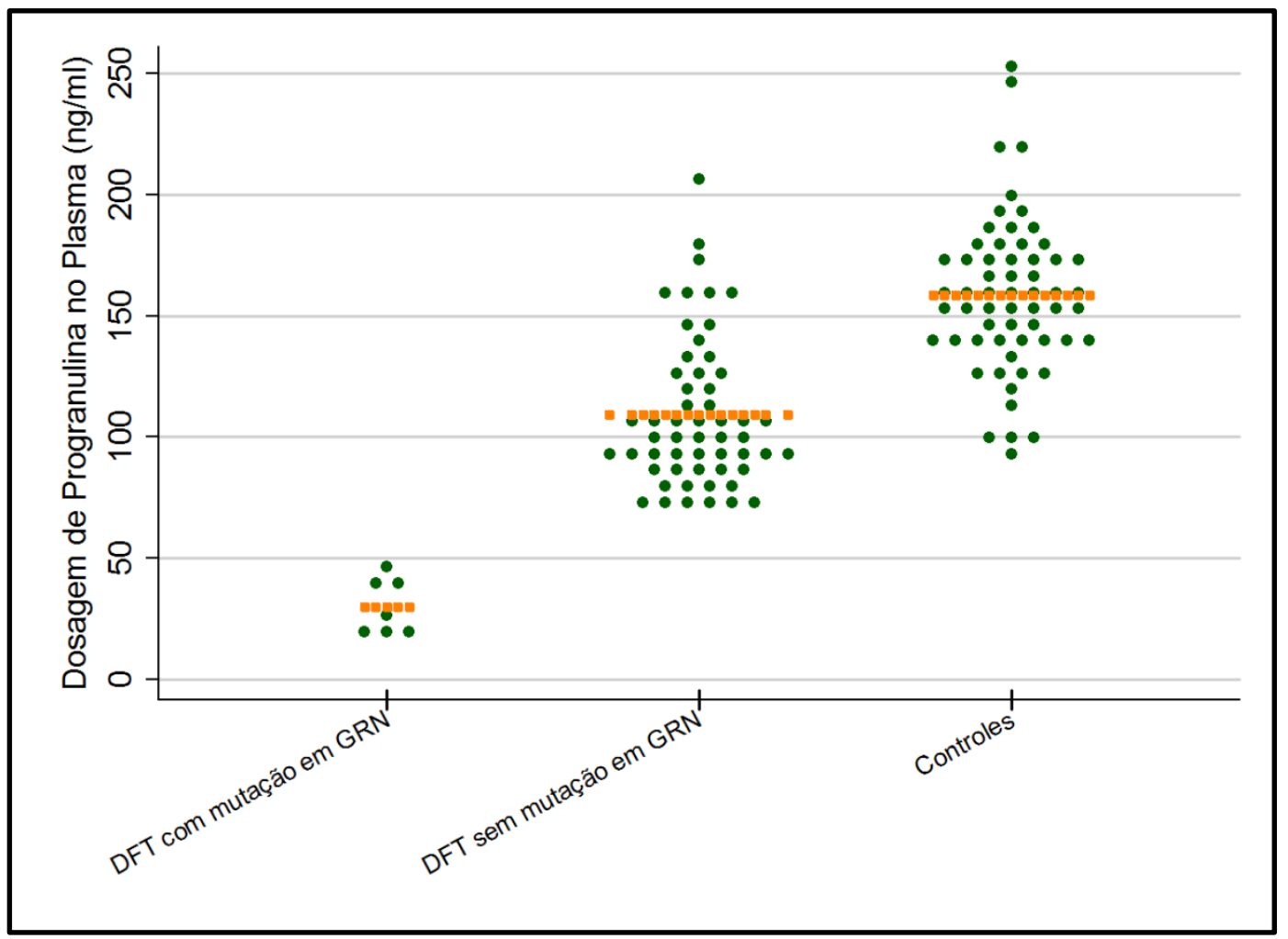

Figura 28 - Dosagem plasmática de progranulina

Legenda: a linha pontilhada em laranja indica a média em cada grupo.

Pela análise ROC não paramétrica e comparando o grupo de DFT com mutação em GRN em relação ao grupo DFT sem mutação em GRN e controles, a sensibilidade e a especificidade da dosagem plasmática de progranulina foram de $100 \%$ para um ponto de corte de $\geq 70 \mathrm{ng} / \mathrm{ml}$. Para um ponto de corte de $\geq 48 \mathrm{ng} / \mathrm{ml}$, a sensibilidade foi de $100 \%$ e especificidade de $85,71 \%$. Os mesmos valores de sensibilidade e especificidade foram obtidos em análise que incluiu apenas os casos de DFT (GRN+ e GRN-, sem controles).

\subsection{Polimorfismos não patogênicos encontrados na casuística}

Variantes não patogênicas em regiões codificadoras de proteína de GRN (Tabela 10) e MAPT (Tabela 11) foram encontradas em probandos e/ou em indivíduos do grupo controle. 
Tabela 10 - Polimorfismos não patogênicos encontrados em GRN

\begin{tabular}{|c|c|c|c|c|}
\hline Polimorfismo & $\begin{array}{l}\text { Alelo } \\
\text { menor }\end{array}$ & $\begin{array}{c}\text { Frequência do } \\
\text { alelo menor no } \\
\text { grupo DFT }\end{array}$ & $\begin{array}{l}\text { Frequência do } \\
\text { alelo menor no } \\
\text { grupo controle }\end{array}$ & $\begin{array}{l}\text { Frequência do } \\
\text { alelo menor na } \\
\text { população" }\end{array}$ \\
\hline $\begin{array}{c}\text { rs25646 } \\
\text { g.10140T>C } \\
\text { p.D128 }\end{array}$ & C & $5(8 \%)$ & $4(6,6 \%)$ & $8,5 \%$ \\
\hline $\begin{array}{c}\text { rs63750723 } \\
\text { g.9097C>T } \\
\text { p.R19W }\end{array}$ & $\mathrm{T}$ & 0 & $2(3,3 \%)$ & $1,4 \%$ \\
\hline $\begin{array}{c}\text { rs } 63750742 \\
\text { g. } 9141 C>T \\
\text { p.D33 }\end{array}$ & $\mathrm{T}$ & $2(3,2 \%)$ & 0 & $0,1 \%$ \\
\hline $\begin{array}{c}\text { g. } 12323 \mathrm{~T}>\mathrm{C} \\
\text { p.T506 }\end{array}$ & C & 0 & $1(1,6 \%)$ & ND \\
\hline $\begin{array}{c}\text { rs } 63751088 \\
\text { g. } 9559 G>A \\
\text { p.G93 }\end{array}$ & A & $1(1,6 \%)$ & 0 & ND \\
\hline
\end{tabular}

Tabela 11 - Polimorfismos não patogênicos encontrados em MAPT

\begin{tabular}{ccccc}
\hline Polimorfismo & $\begin{array}{c}\text { Alelo } \\
\text { menor }\end{array}$ & $\begin{array}{c}\text { Frequência do } \\
\text { alelo menor no } \\
\text { grupo DFT }\end{array}$ & $\begin{array}{c}\text { Frequência do } \\
\text { alelo menor no } \\
\text { grupo controle }\end{array}$ & $\begin{array}{c}\text { Frequência do } \\
\text { alelo menor na } \\
\text { população\# }\end{array}$ \\
\hline $\begin{array}{c}\text { rs11568305 } \\
\text { g. } 107232 \mathrm{G}>\mathrm{A} \\
\text { p.P270 }\end{array}$ & $\mathrm{A}$ & $2(3,2 \%)$ & $4(6,6 \%)$ & $3,2 \%$ \\
$\begin{array}{c}\mathrm{r} 1052553 \\
\text { g. } 107103 \mathrm{~A}>\mathrm{G} \\
\text { p.A227 }\end{array}$ & $\mathrm{G}$ & $16(25,8 \%)$ & $10(16,6 \%)$ & $8,8 \%$ \\
$\begin{array}{c}\text { rs17652121 } \\
\text { g.107187T>C } \\
\text { p.N255 }\end{array}$ & $\mathrm{C}$ & $16(25,8 \%)$ & $10(16,6 \%)$ & $8,7 \%$ \\
\hline
\end{tabular}

Legenda: \#= baseado em dados do 1000 Genomes Project. ${ }^{350}$ 


\section{DISCUSSÃO}

Frequências das mutações em MAPT e GRN e hereditariedade. Foram encontradas mutações patogênicas de $G R N$ em seis, e uma mutação patogênica de MAPT em um dos 62 probandos da casuística. Assim, a frequência de mutações patogênicas de GRN nesta casuística foi de 9,6\% e de MAPT, de 1,6\%. Quase todas as mutações foram identificadas em pacientes com antecedente familiar positivo de DFT, de modo que a frequência de mutações de $G R N$ em casos familiais de DFT foi de $33,3 \%$ e de mutações de MAPT em casos familiais de DFT foi de $6,7 \%$. Entre os 28 probandos com história familiar de demência, em seis identificamos mutações em GRN $(21,4 \%)$. Não foram identificadas mutações patogênicas em GRN ou MAPT nos casos esporádicos de DFT.

A frequência de mutações em GRN desta casuística foi similar à observada em casuísticas de países europeus, e mais alta do que a encontrada em países asiáticos, como se pode ver na Tabela 12. A frequência de mutações de GRNem casos famíliais de DFT foi mais alta do que a observada na França, Portugal, EUA e Reino Unido, mas similar à relatada na casuística italiana. Mutações de GRN são particularmente frequentes em casuísticas italianas, e foram encontradas em $24-71 \%$ dos casos familiais de DFT. ${ }^{351-353}$ No norte da Itália, a mutação GRN p.T272Sfs ${ }^{*} 10$ é a mais frequente, e os resultados de um estudo que realizou análise de haplótipos indicaram que a maior parte dos casos daquela região descendem de um único fundador. ${ }^{138,354}$

A frequência de mutações em MAPT foi mais baixa do que a publicada pelos grupos francês, belga, inglês e japonês (Tabela 12). A frequência de mutações em casos familiais de DFT foi similar à observada na casuística norte-americana. No Reino Unido, a mutação de MAPTIVS10+16 é particularmente comum (na casuística de Manchester, por exemplo, 16 dos 17 casos de DFT com mutação em MAPT apresentavam essa mutação), motivo pelo qual a frequência de mutações de MAPT em casos familiais é mais alta do que nas demais casuísticas. ${ }^{80}$ Acredita-se que essa mutação tenha se originado no norte do país de Gales, e de lá se espalhado pelo restante do Reino Unido, EUA e Austrália. ${ }^{355}$ 
Tabela 12 - Frequência de mutações patogênicas de GRN e de MAPT em diversas casuísticas

\begin{tabular}{|c|c|c|c|c|}
\hline País & $\mathbf{N}$ & Fenótipos incluídos & $\begin{array}{c}\text { Frequência } \\
\text { de mutações } \\
\text { de GRN }\end{array}$ & $\begin{array}{c}\text { Frequência } \\
\text { de mutações } \\
\text { de } M A P T\end{array}$ \\
\hline França & 833 & $\begin{array}{l}\text { vcDFT, APP, DFT- } \\
\text { DNM, PSP, SCB }\end{array}$ & $\begin{array}{c}\text { Tot: } 7 \% \\
\text { Fam: } 14 \% \\
\text { Esp:2\% }\end{array}$ & $\begin{array}{l}\text { Tot: } 4,7 \% \\
\text { Fam: } 10 \% \\
\text { Esp: } 0 \%\end{array}$ \\
\hline Bélgica & 275 & $\begin{array}{l}\text { vcDFT, vnfAPP, } \\
\text { vsAPP, DFT-DNM, } \\
\text { PSP, SCB }\end{array}$ & Tot: 3\% & Tot: $9,8 \%$ \\
\hline EUA & 374 & $\begin{array}{l}\text { vcDFT, vnfAPP, } \\
\text { vsAPP, DFT-DNM }\end{array}$ & $\begin{array}{l}\text { Fam: } 7,6 \% \\
\text { Esp: } 1,5 \%\end{array}$ & $\begin{array}{l}\text { Fam: } 6,3 \% \\
\text { Esp: } 1,5 \%\end{array}$ \\
\hline Holanda & 364 & $\begin{array}{c}\text { vcDFT, vsAPP, } \\
\text { vnfAPP, DFT-DNM }\end{array}$ & Tot: $11 \%$ & Tot: $6 \%$ \\
\hline $\begin{array}{l}\text { Reino Unido } \\
\text { (Manchester) }\end{array}$ & 223 & $\begin{array}{l}\text { vcDFT, vnfAPP, } \\
\text { vsAPP, DFT-DNM }\end{array}$ & $\begin{array}{l}\text { Tot: } 6 \% \\
\text { Fam: } 17 \%\end{array}$ & $\begin{array}{l}\text { Tot: } 8 \% \\
\text { Fam: } 21 \%\end{array}$ \\
\hline $\begin{array}{l}\text { Reino Unido } \\
\text { (Londres) }\end{array}$ & 212 & $\begin{array}{l}\text { vcDFT, vnfAPP, } \\
\text { vsAPP, DFT-DNM, } \\
\text { PSP, SCB }\end{array}$ & $\begin{array}{l}\text { Tot: } 12 \% \\
\text { Fam: } 20 \% \\
\text { Esp: } 0,9 \%\end{array}$ & $\begin{array}{l}\text { Tot: } 17,9 \% \\
\text { Fam: } 38 \% \\
\text { Esp: } 0 \%\end{array}$ \\
\hline Itália & 205 & $\begin{array}{c}\text { vcDFT, APP, DFT- } \\
\text { DNM }\end{array}$ & $\begin{array}{l}\text { Tot: } 15,6 \% \\
\text { Fam: } 24,8 \%\end{array}$ & ND \\
\hline Suécia & 121 & $\begin{array}{c}\text { vcDFT, vsAPP, } \\
\text { vnfAPP, DFT-DNM }\end{array}$ & Tot: $6,6 \%$ & ND \\
\hline İndia & 81 & $\begin{array}{l}\text { vcDFT, vsAPP, APP, } \\
\text { DFT-DNM, PSP, SCB }\end{array}$ & Tot: $0 \%$ & Tot: $0 \%$ \\
\hline Coréia do Sul & 75 & $\begin{array}{c}\text { vcDFT, vsAPP, } \\
\text { vnfAPP, DFT-DNM }\end{array}$ & Tot: $0 \%$ & Tot: $0 \%$ \\
\hline Japão & 62 & $\begin{array}{l}\text { vcDFT, APP, DFT- } \\
\text { DNM, PSP, SCB }\end{array}$ & $\begin{array}{l}\text { Tot: } 1,6 \% \\
\text { Fam: } 2,3 \% \\
\text { Esp: } 0 \%\end{array}$ & $\begin{array}{c}\text { Tot: } 9,6 \% \\
\text { Fam: } 11,9 \% \\
\text { Esp: } 3,7 \%\end{array}$ \\
\hline Portugal & 36 & $\begin{array}{l}\text { vcDFT, vsAPP, DFT- } \\
\text { DNM, SCB }\end{array}$ & $\begin{array}{l}\text { Tot:3\%; } \\
\text { Fam:6\%; } \\
\text { Esp:0\% }\end{array}$ & ND \\
\hline
\end{tabular}

Legenda: ND: não disponível; Tot: frequência na amostra completa; Fam: frequência em casos familiais; Esp: frequência em casos esporádicos; vcDFT: variante comportamental da demência frontotemporal; vsAPP: variante semântica da afasia progressiva primária; DFT-DNM: demência frontotemporal com doença do neurônio motor; SCB: síndrome corticobasal, PSP: paralisia supranuclear progressiva. Referências: França ${ }^{78}$; Bélgica ${ }^{79}$; Holanda ${ }^{49}$; Reino Unido (Manchester) ${ }^{80}$; Reino Unido (Londres) ${ }^{83}$; Itália' ${ }^{138,353}$; EUA ${ }^{54}$; Suécia ${ }^{356}$; Coréia do Sul ${ }^{193}$; Portuga| ${ }^{357}$; Japão ${ }^{192}$; India ${ }^{358}$.

As frequências de história familiar de demência (45\%) e de DFT (24\%) na casuística foram compatíveis com as frequências encontrada em estudos 
prévios. ${ }^{47,48,359}$ A frequência de antecedente familiar de DFT na casuística foi mais alta na vnfAPP (33\%) do que na vcDFT (23\%) e na vsAPP (22\%). Em casos com história familiar de padrão autossômico dominante, a vcDFT consistentemente é a variante em que a frequência de antecedente familiar de DFT é mais alta. ${ }^{47-50}$ Mas ao se considerar história familiar positiva se houver pelo menos um familiar de primeiro grau afetado (como foi neste estudo), a frequência entre casos de vnfAPP foi mais alta do que nos casos de vcDFT em dois estudos. ${ }^{47,49}$ É possível que algumas discrepâncias com dados da literatura se devam a viés de encaminhamento de casos. Apesar dos esforços para incluir tanto casos familiais quanto esporádicos, pode-se imaginar que os pacientes com história familiar positiva eram mais predispostos a participar da pesquisa e/ou foram mais frequentemente encaminhados para inclusão no estudo.

O escore de Goldman modificado tem sido utilizado em alguns estudos para caracterizar a história familiar de pacientes com DFT. ${ }^{47,83} \mathrm{O}$ escore 1 indica padrão de herança autossômico dominante, com pelo menos três familiares com DFT, ELA, SCB e/ou PSP, em duas gerações, sendo que um dos membros da família é parente de primeiro grau dos outros dois. O escore 2 indica agregação familial em que pelo menos três indivíduos de uma mesma família desenvolveram demência ou ELA, mas sem preencher critérios para escore 1. O escore 3 é utilizado para probandos com apenas um familiar de primeiro grau que tenha apresentado demência pré-senil ou ELA; o escore 3,5 é utilizado caso o início dos sintomas do familiar de primeiro grau tenha ocorrido após os 65 anos de idade. O escore 4 indica história familiar ausente ou desconhecida.

Devido às informações relacionadas a antecedentes familiares serem limitadas em muitos casos, esse escore não pode ser aplicado na casuística completa. Pela análise dos heredogramas dos probandos com mutações encontradas, o escore 1 caracterizaria o histórico familiar apenas do probando DFT 17, já que vários probandos tiveram familiares diagnosticados com DA, diagnóstico que não é contemplado por este escore. O escore 2 seria apropriado para definir a história familiar da maior parte dos probandos: DFT 22, DFT 53, DFT 58, DFT 63 e DFT 64. A paciente DFT 11 seria classificada com escore 3. 
Mutações em GRN. Das seis mutações patogênicas identificadas em GRN encontradas, duas ainda não foram relatadas na literatura em casos de DFT (p.Q130X e p.D317Afs*11). Quatro mutações são do tipo frameshift (p.Q257Pfs*26, p.V200Gfs ${ }^{*} 18$, p.S301Cfs*60, e p.D317Afs*11) e duas mutações são nonsense (p.Q300X e p.Q130X).

A mutação GRN p.10144C>T/GRN p.Q130X encontrada no probando DFT 58 ainda não foi relatada na literatura em casos de DFT, mas foi identificada em um homem de 63 anos com adenocarcinoma de intestino grosso, em um banco de dados de mutações somáticas em neoplasias humanas (Projeto COSMIC - Catalog of Somatic Mutations in Cancer), como COSM187683. ${ }^{360}$ Nessa mutação, a substituição de uma citosina por uma timina leva a formação de um códon de parada (TAG) prematuro no éxon 5 do gene, caracterizando uma mutação nonsense. Além de ser uma mutação nonsense, dois outros achados ajudam a corroborar a patogenicidade da mutação: a baixa dosagem de progranulina no plasma do probando com a mutação, e a identificação da mesma mutação na irmã da paciente.

A mutação identificada no probando DFT 63 foi a GRN g.1144411445delAC/GRN p.D317Afs*11. A mutação ainda não foi descrita na literatura, mas alguns dados corroboram a patogenicidade da mutação. Além de a mutação não ter sido identificada no grupo controle, ela foi encontrada nos dois indivíduos sintomáticos da família. Também, os níveis de progranulina plasmática da mãe do probando foram baixos, e a análise da deleção realizada pelo SIFT indel prediz decaimento de RNA mensageiro mediado por mutações nonsense. ${ }^{361}$ O SIFT indel é uma ferramenta que foi desenvolvida para predizer as consequências de inserções e/ou deleções (indels) em regiões codificadoras do genoma, e está disponível no site http://sift.jcvi.org/.

A mutação GRN g.10976_10977dupCC/GRN p.Q257Pfs*26 identificada no probando DFT 11 foi associada a nível baixo de progranulina no plasma da paciente, e deve causar decaimento de RNA mensageiro mediado por mutação nonsense, de acordo com o algoritmo SIFT indel. ${ }^{361}$ Esta mutação foi recentemente relatada em dois probandos de uma casuística portuguesa de DFT. ${ }^{362}$ Ambos apresentavam o fenótipo de vcDFT, com início dos sintomas entre os 50 e 54 anos, não tinham antecedente familiar de DFT, e apresentavam níveis reduzidos de progranulina no soro.

A mutação GRN p.Q300X encontrada no probando DFT 22 já foi descrita na literatura. Essa mutação pontual leva a formação de um códon de parada (mutação 
nonsense), resultando em uma proteína truncada. Beck et al. descreveram a mutação em um paciente com diagnóstico de vcDFT. ${ }^{83}$ Chen-Plotkin et al. relataram dois probandos com a mesma mutação, em estudo colaborativo de 46 centros, mas o fenótipo desses dois probandos não foi descrito. ${ }^{140}$

Outra mutação já descrita na literatura é a mutação GRN g.10679G>C/GRN p.V200Gfs*18, identificada no probando DFT 53. Gass et al. encontraram essa mutação em um caso de DLFT cujo início dos sintomas ocorreu aos 55 anos e óbito, aos 61 anos. ${ }^{84}$ Prediz-se que essa mutação, localizada no sítio doador de splicing do éxon 7, faça com que o éxon 7 seja omitido na transcrição, e a mudança da matriz de leitura resultante leve à ocorrência de um códon de parada prematuro. ${ }^{77,84} \mathrm{~A}$ substituição de guanina por adenina (ao invés de citosina) na mesma posição também é patogênica (GRN g.10679G>A/GRN p.V200Gfs*18). Essa mutação foi descrita em pacientes diagnosticados com SCB (duas irmãs canadenses de ascendência chinesa, com início de sintomas aos 57 e 62 anos) e vcDFT.(dois probandos na França e um probando na Suécia). ${ }^{148,356,363}$

No probando DFT 64, a mutação identificada foi a GRN g.1130711308dupGT/GRN p.S301Cfs*60. Assim como as demais, esta mutação foi associada a redução de níveis de progranulina no plasma Além disso, a predição do algoritmo utilizado pelo SIFT indel é de que essa inserção causa decaimento de RNA mensageiro mediado por mutações nonsense, ${ }^{361}$ o que corrobora a patogenicidade da mutação. Esta mutação foi previamente identificada em casuísticas portuguesas de DFT. Guerreiro et al. descreveram uma família cujo probando foi diagnosticado com SCB de início aos 50 anos de idade, mas que também apresentava alterações de comportamento compatíveis com uma síndrome frontal, como desinibição, apatia, hiperfagia e comportamentos ritualísticos. ${ }^{357}$ Nessa família com cinco indivíduos acometidos, o início dos sintomas ocorreu entre os 50 e 70 anos de idade, e a duração da doença variou entre 2 e 9 anos. Almeida et al. descreveram outros dois probandos com a mesma mutação, um diagnosticado com SCB de início aos 43 anos de idade e outro que recebeu diagnóstico de vcDFT, e cujos sintomas iniciaram aos 63 anos. ${ }^{362}$ Apenas um desses probandos tinha história familiar positiva com familiares de primeiro grau afetados com DFT.

A apresentação clínica dos pacientes com mutações em GRN foi bastante variável. A idade de início dos sintomas dos probandos variou entre 44 e 64 anos, 
dentro da variação já publicada na literatura. 49,78-81,84,127,135, 138 É interessante notar que mesmo dentro de uma família, a idade de início dos sintomas variou significativamente, como já foi observado previamente. ${ }^{139}$ Enquanto que o probando DFT 58 começou a apresentar sintomas aos 52 anos, sua mãe apenas desenvolveu sintomas cognitivos aos 77 anos - ou seja, houve nessa família uma variação de 25 anos na idade de início dos sintomas. No caso do probando DFT 64, os primeiros sintomas apareceram quando ele tinha 44 anos, enquanto que sua mãe desenvolveu sintomas aos 58 anos. O início dos sintomas da paciente DFT 22 ocorreu aos 64 anos, enquanto que em seu irmão, ocorreu aos 57 anos. No caso da paciente DFT 58, os sintomas apareceram aos 48 anos, enquanto que sua irmã só desenvolveu manifestações cognitivas aos 54 anos. A observação de início de sintomas ocorrendo mais precocemente em uma geração do que na geração anterior já foi previamente relatada (apesar de as causas para essa aparente antecipação ainda não terem sido elucidadas), mas início dos sintomas ocorrendo em filhos mais tardiamente que em seus pais também pode ocorrer. ${ }^{139}$

Três dos probandos (50\%) apresentavam o fenótipo vnfAPP, incluindo os probandos DFT 11, DFT 22, e DFT 53. A mãe do probando DFT 63 também desenvolveu quadro compatível com vnfAPP. Isso difere do relatado previamente, em que o fenótipo vcDFT é o mais frequentemente descrito. ${ }^{135,139}$ Ambas pacientes DFT 11 e DFT 22 apresentavam apraxia de fala. A apresentação da APP do probando DFT 53 foi atípica, pois apesar de o quadro clínico ser mais compatível com a vnfAPP, o paciente também apresentava prejuízo do conhecimento semântico e atrofia do lobo temporal anterior. Esse padrão poderia ser classificado como APP do tipo misto, como proposto por Mesulam, e já foi relatado em pacientes com mutações em GRN.83,364 Corroborando o fato de que a APP pode se apresentar de maneira atípica nas mutações de GRN, Rohrer et al. descreveram um paciente com APP que apresentava características da variante logopênica (como anomia grave com pausas para encontrar palavras e comprometimento importante da memória operacional verbal), associadas a características da variante não fluente (como agramatismo e dificuldade na repetição de palavras). ${ }^{365}$

Os demais probandos desenvolveram o fenótipo de vcDFT, com ou sem parkinsonismo. Apesar de parkinsonismo ser observado com frequência relativamente alta entre os pacientes com mutações em $G R N,{ }^{89}$ por vezes o uso de neurolépticos 
durante o curso da doença pode gerar dúvidas sobre a etiologia dos sinais parkinsonianos, como é o caso da paciente DFT 58 e de sua irmã. Outro fator limitante para a análise da frequência de parkinsonismo em pacientes com mutações em GRN é o fato de poder aparecer apenas tardiamente na evolução da doença. Isso poderia explicar porque parkinsonismo foi relatado em $73 \%$ dos casos com mutação em GRN em um estudo neuropatológico, enquanto que a frequência encontrada em casuísticas clínicas foi mais baixa, entre 19-47\%. ${ }^{78,79,139,366}$

A ocorrência de distúrbio de memória episódica nas fases iniciais da doença causada por mutações em GRN relatada na literatura também foi observada em alguns casos desta casuística. A paciente DFT 58, por exemplo, teve como sintomas iniciais perda de memória para fatos recentes e desorientação topográfica, o que acabou levando a um diagnóstico inicial de DA possível. A paciente DFT 11 começou a se queixar de esquecimento dois anos antes do aparecimento dos sintomas propriamente relacionados a fala ("gagueira"), e sua mãe recebeu diagnóstico de DA por ter como sintomas iniciais esquecimento para fatos recentes e apatia. Apesar de ser uma característica considerada atípica na vcDFT esporádica, comprometimento precoce da memória episódica não é incomum em pacientes com mutações do gene da progranulina. ${ }^{3}$ Rademakers et al. relataram que $30 \%$ dos pacientes com a mutação GRN p.R493X apresentavam perda de memória como queixa inicial, e 9\% receberam diagnóstico inicial de DA. ${ }^{139}$ Beck et al. encontraram comprometimento de memória verbal em 6 dos 13 pacientes testados (46\%), e comprometimento de memória visual em 8 dos 12 pacientes testados (66\%). ${ }^{83}$ Deve-se ressaltar, no entanto, que apesar de comprometimento precoce de memória episódica ser considerado atípico na vcDFT esporádica, há estudos que demonstraram desempenho similar em testes de memória episódica de pacientes com vcDFT e com DA. ${ }^{367}$

Não foram relatados sintomas psicóticos em nenhum dos probandos, apenas delírios na irmã da paciente DFT 58 e alucinações na mãe da paciente DFT 11. Dessa forma, sintomas psicóticos não parecem ser frequentes nesta casuística, contrariando o dado apresentado pelo grupo francês de psicose em $25 \%$ dos indivíduos com mutações em $G R N .^{78}$

Em duas famílias, a penetrância da mutação parece ter sido incompleta. A mãe da paciente DFT 58 faleceu aos 60 anos devido a um tromboembolismo pulmonar. Já na família do probando DFT 64, a tia do probando (II-3, Figura 24) faleceu aos 87 anos 
sem ter desenvolvido quadro demencial (apesar de seu filho, III-1, ter sido diagnosticado com vcDFT). Como em ambos os casos (II-1 da Figura 14 e II-3 da Figura 24), um dos progenitores dessas pessoas também desenvolveu quadro demencial de início precoce (ou pelo menos antes dos 70 anos de idade), é possível que essas pessoas tenham falecido antes de desenvolver sintomas. De fato, a penetrância das mutações de GRN é alta, mas dependente da idade. Gass et al. calcularam a penetrância em $50 \%$ até os 60 anos de idade, cerca de $90 \%$ aos 70 anos, e próxima de $100 \%$ aos 85 anos. ${ }^{84} \mathrm{Na}$ mutação GRN p.R493X, a mais comumente relatada no mundo e que representa cerca de $20 \%$ das mutações em GRN encontradas nos EUA, a penetrância foi estimada em $60 \%$ aos 60 anos de idade e maior do que $95 \%$ aos 70 anos. ${ }^{139}$ Na mutação GRN p.T272Sfs ${ }^{\star} 10$, particularmente frequente no norte da Itália, a penetrância foi calculada em $97,3 \%$ até os 73 anos de idade. ${ }^{138}$

A duração da doença pôde ser observada em apenas dois probandos. A paciente DFT 11 faleceu dois anos após o início dos sintomas, mas de causas não relacionadas à doença neurodegenerativa. O probando DFT 63 teve um curso de doença prolongado, de 15 anos, mas inferior a um caso de vcDFT relatado por Benussi et al., que foi avaliado aos 83 anos, 23 anos após o início dos sintomas. ${ }^{138}$

Em relação à neuroimagem estrutural e funcional, as alterações observadas nos pacientes foram compatíveis com as descritas na literatura. ${ }^{99}$ Entre os pacientes com vcDFT da casuística, todos apresentavam atrofia não apenas nos lobos frontais e temporais, mas também acometendo regiões parietais, como se pode observar nas Figuras 15, 16, 18 e 23.

Dentre os casos desta casuística em que havia imagens ponderadas em T2/FLAIR para avaliação da substância branca, alterações significativas de sinal foram observadas nos pacientes DFT 58 (Figura 13) e sua irmã (Figura 14), DFT 63 (Figura 18) e sua mãe (Figura 21), enquanto que nos pacientes DFT 53 e DFT 64 os focos de hipersinal em substância branca eram esparsos (DFT53, Figura 11) ou ausentes (DFT 64, Figura 23). Na Figura 16, pode-se observar que as alterações de sinal em substância branca estavam ausentes no início do quadro, e apenas apareceram ao longo da evolução da doença e em regiões de maior atrofia. Isso sugere que o hipersinal na substância branca pode ser um achado mais tardio da doença associada a mutações de GRN. 
Graus variáveis de focos de hipersinal na substância branca subcortical foram relatados em $20-40 \%$ dos casos com mutações em GRN. ${ }^{148,149}$ Este achado pode ser útil para identificação de mutações do gene da progranulina, mas é importante lembrar que focos de hipersinal na substância branca podem ser observados (ainda que de modo infrequente) nas formas esporádicas da DFT, ${ }^{368}$ e que existem leucoencefalopatias que apresentam fenótipo similar ao da vcDFT, como a osteodisplasia lipomembranosa policística com leucoencefalopatia esclerosante (ou doença de Nasu-Hakola) e a leucoencefalopatia de início adulto com esferoides axonais e glia pigmentada. ${ }^{369-371}$ Curiosamente, ambas podem ser consideradas microgliopatias. ${ }^{372,373}$

A osteodisplasia lipomembranosa policística com leucoencefalopatia esclerosante é uma doença autossômica recessiva causada por mutações no gene TREM2 (triggering receptor expressed on myeloid cells 2) ou no gene TYROB (tyrosine kinase binding protein). ${ }^{369,374}$ Clinicamente, se apresenta com dores ósseas e fraturas de início durante a terceira década de vida, associadas à presença de cistos ósseos. Por volta da quarta década de vida aparecem insidiosamente mudanças na personalidade, que eventualmente progridem para uma demência do tipo frontotemporal. Distúrbio de marcha, sinais piramidais e crises epilépticas podem aparecer no curso da doença, e o óbito em geral ocorre antes dos 50 anos de idade. ${ }^{374,375} \mathrm{~A}$ neuroimagem caracteristicamente mostra calcificações nos gânglios da base, atrofia frontal e temporal, e hipersinal difuso na substância branca em imagens de ressonância magnética ponderadas em T2. Essas alterações de substância branca podem estar ausentes nas fases iniciais, têm leve predomínio nos lobos frontais e tipicamente poupam as fibras em U. ${ }^{374,375}$ Recentemente, algumas famílias foram identificadas com o fenótipo de vcDFT com leucoencefalopatia, mas sem alterações ósseas. ${ }^{376}$

A leucoencefalopatia de início adulto com esferoides axonais e glia pigmentada é uma doença que ocorre em adultos (idade média de início 45 anos, mas variando entre a segunda e oitava décadas de vida), que frequentemente é diagnosticada como vcDFT ou SCB, devido a presença de sintomas comportamentais e motores. Parkinsonismo é frequente, e espasticidade, ataxia cerebelar, e crises epilépticas podem aparecer no curso da doença. ${ }^{372,377}$ A ressonância magnética de encéfalo tipicamente mostra focos de hipersinal na substância branca, que vão se tornando 
confluentes com a progressão da doença, e que predominam em regiões frontais ou frontoparietais. $\mathrm{O}$ acometimento do corpo caloso é comum, e as fibras em U são tipicamente poupadas. ${ }^{378}$ Esta leucoencefalopatia foi recentemente associada a mutações no gene CSF1R (receptor do fator estimulador de colônias 1), e pode se apresentar como doença familial ou esporádica (com mutações de novo). ${ }^{372}$

Dosagem plasmática de progranulina. A dosagem plasmática de progranulina foi marcador adequado das mutações patogênicas de GRN nesta casuística, identificando todos os pacientes com mutações nulas em GRN. Isto está de acordo com os achados de estudos prévios. ${ }^{152-155,351,356,379-383}$

A dosagem média de progranulina no plasma no grupo de pacientes com mutações em GRN foi de $29,8 \mathrm{ng} / \mathrm{ml}$, variando entre 17,8 e 40,4 . Os valores encontrados em mutações nulas de GRN em estudos prévios que dosaram progranulina no plasma, utilizando o mesmo kit de ELISA (Adipogen ${ }^{\circledR}$ ) estão detalhados na Tabela 13. Pode-se observar que as médias encontradas no presente estudo são mais baixas do que as médias publicadas na literatura, e também que há grande variação nos resultados entre os estudos. No estudo de Ghidoni et al., ${ }^{154}$ por exemplo, dosagens de até $107 \mathrm{ng} / \mathrm{ml}$ foram encontradas em pacientes com mutações nulas de GRN, enquanto que no presente estudo a média encontrada nos pacientes com DFT sem mutação foi de $109 \mathrm{ng} / \mathrm{ml}$.

Tabela 13 - Valores da dosagem de progranulina plasmática em estudos prévios

\begin{tabular}{|c|c|c|c|c|c|c|}
\hline \multirow[b]{2}{*}{ Referência } & \multicolumn{2}{|c|}{$\begin{array}{c}\text { DFT com mutação } \\
\text { nula em GRN }\end{array}$} & \multicolumn{2}{|c|}{$\begin{array}{c}\text { DFT sem mutação } \\
\text { em GRN }\end{array}$} & \multicolumn{2}{|c|}{ Controles } \\
\hline & $\mathbf{n}$ & 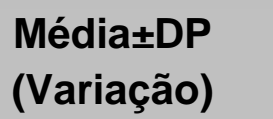 & $n$ & 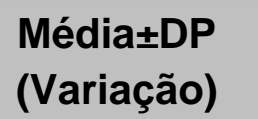 & $\mathbf{n}$ & $\begin{array}{l}\text { Média土DP } \\
\text { (Variação) }\end{array}$ \\
\hline $\begin{array}{l}\text { Ghidoni et } \\
\text { al., } 2008\end{array}$ & $6^{*}$ & $61,6 \pm 25,9$ & 63 & $197,9 \pm 67,6$ & 75 & ND \\
\hline $\begin{array}{l}\text { Finch et } \\
\text { al., } 2009\end{array}$ & 8 & $\begin{array}{c}68 \pm 16 \\
(53-94)\end{array}$ & 191 & $\begin{array}{c}220 \pm 47 \\
(115-386)\end{array}$ & 70 & $\begin{array}{c}228 \pm 50 \\
(138-376)\end{array}$ \\
\hline $\begin{array}{l}\text { Carecchio } \\
\text { et al., } 2009\end{array}$ & 4 & $36,4 \pm 12,5$ & 42 & $216 \pm 12,2$ & ND & ND \\
\hline $\begin{array}{l}\text { Ghidoni et } \\
\text { al., } 2012\end{array}$ & 72 & $\begin{array}{c}38,4^{\#} \\
(10,9-107,8)\end{array}$ & 149 & ND & 309 & $\begin{array}{c}125,6^{\#} \\
(61,8-338,4)\end{array}$ \\
\hline $\begin{array}{l}\text { Bernardi et } \\
\text { al., } 2012\end{array}$ & 11 & $\begin{array}{c}38,6 \pm 12,7 \\
(20-62)\end{array}$ & & & 15 & $\begin{array}{c}175,7 \pm 25,4 \\
(142-221) \\
\end{array}$ \\
\hline
\end{tabular}




\begin{tabular}{ccccccc}
\hline $\begin{array}{c}\text { Piscopo et } \\
\text { al., 2013 }\end{array}$ & - & - & - & - & 107 & $\begin{array}{c}169,0 \pm 77,7 \\
(70,3-473,4)\end{array}$ \\
Este & 7 & $\begin{array}{c}29,8 \pm 11,9 \\
(17,8-48,4)\end{array}$ & 55 & $\begin{array}{c}109,0 \pm 30,7 \\
(70,2-206,3)\end{array}$ & 60 & $\begin{array}{c}158,4 \pm 32,0 \\
(94,8-249,9)\end{array}$ \\
estudo & & & & & \\
\hline
\end{tabular}

Legenda: *com a mutação GRN p.T272Sfs*10; \#: mediana; ND: dado não disponível; DP: desvio padrão. Valores em ng/ml. Referências: Ghidoni et al., 2008; ${ }^{153}$ Finch et al., 2009;152 Carecchio et al., 2009;379 Ghidoni et al., 2012;154 Bernardi et al., 2012;351 Piscopo et al., 2013. ${ }^{384}$

Outros estudos que utilizaram o kit de ELISA da Adipogen ${ }^{\circledR}$ mensuraram os níveis de progranulina no soro, ao invés do plasma, e de modo similar, os resultados variaram entre os estudos. A média encontrada em pacientes com mutações nulas em GRN, por exemplo, variou entre 33,8 a 50,5 em três estudos. ${ }^{356,362,385}$ Almeida et al. avaliaram a correlação entre os níveis em plasma e soro, e encontraram boa correlação (Spearman $\rho=0,709$, $p<0,001$ ), mas os valores no plasma eram $8,7 \%$ mais baixos do que no soro. ${ }^{362}$

Alguns estudos utilizaram 0 kit de ELISA produzido pela R\&D Systems ${ }^{\circledR} .{ }^{155,362,381}$ Almeida et al. compararam os valores obtidos na dosagem de progranulina no soro com o kit Adipogen ${ }^{\circledR} \operatorname{com}$ os valores obtidos com o kit R\&D Systems ${ }^{\circledR}$. Apesar de haver boa correlação entre os valores $(\rho=0,810, p<0,001)$, os níveis mensurados com o kit Adipogen ${ }^{\circledR}$ eram significativamente mais altos que os mensurados com o outro kit. Em controles, por exemplo, a média de progranulina sérica foi de $167,9 \pm 51,3 \mathrm{ng} / \mathrm{ml}$ com o kit Adipogen ${ }^{\circledR}$ e de $44,1 \pm 9,8 \mathrm{ng} / \mathrm{ml}$ com o kit R\&D Systems ${ }^{\circledR} .362$

Em relação ao valor de corte mais adequado para identificação de mutações nulas em GRN, os estudos publicados sugeriram valores diferentes. Finch et al., utilizando o kit de ELISA da Adipogen ${ }^{\circledR}$, sugeriram um valor de corte de $112 \mathrm{ng} / \mathrm{ml}$ para diferenciar os carreadores de mutações nulas em GRN de indivíduos sem mutações, com sensibilidade de 99,49\% e especificidade de 99,61\%. ${ }^{152}$ Esse valor de corte, no entanto, não é adequado para a casuística deste estudo, já que classificaria erroneamente 37 pacientes com DFT $(67,2 \%)$ e cinco indivíduos do grupo controle $(8,3 \%)$.

Ghidoni et al., também utilizando o kit de ELISA da Adipogen ${ }^{\circledR}$, inicialmente sugeriram 110,9ng/ml como valor de corte para diferenciar pacientes com DFT e mutações em GRN de pacientes com DFT sem mutações em GRN e de controles, com sensibilidade de 92,8\% e especificidade de 100\%. ${ }^{153}$ Posteriormente, em 2012 , Ghidoni et al. publicaram um estudo multicêntrico realizado no norte da ltália que 
incluiu 72 indivíduos com mutação em GRN, 309 indivíduos cognitivamente normais e 635 pacientes com doenças neurodegenerativas não causadas por deficiência de progranulina (que incluíam: comprometimento cognitivo leve, DA, DFT, demência com corpúsculos de Lewy e SCB). Nesse estudo, o valor de corte para progranulina plasmática foi de $61,55 \mathrm{ng} / \mathrm{ml}$ para identificar mutações nulas em GRN com sensibilidade de $95,8 \%$ e especificidade de $99,6 \% .{ }^{154}$ Esse valor de corte é o mais aproximado do valor encontrado neste estudo $(70 \mathrm{ng} / \mathrm{ml}$ para sensibilidade e especificidade de $100 \%$ ), e parece mais adequado para a casuística incluída neste estudo pois identificaria corretamente todos os pacientes com mutações patogênicas em GRN. O nível de $70 \mathrm{ng} / \mathrm{ml}$ como ponto de corte para identificar mutações nulas de GRN também foi proposto por Gómez-Tortosa et al.. ${ }^{382}$

Curiosamente, os níveis de progranulina no plasma do grupo de pacientes com DFT sem mutações em GRN foi menor do que o do grupo controle. Alguns estudos relataram valores similares de progranulina plasmática entre os grupos com DFT sem mutações em GRN e os respectivos grupos controle, 152,153,362,381 mas resultados similares aos encontrados na casuística deste estudo também foram apresentados. ${ }^{380}$ A explicação para a diferença entre o grupo controle e o grupo de DFT sem mutação não está clara. Há evidências de que os níveis de progranulina no plasma aumentam com a idade, e são mais altos em mulheres. ${ }^{152,326}$ Esses fatores não devem explicar a diferença encontrada neste estudo, já que os grupos não foram diferentes em relação a idade e sexo. Um estudo pequeno conduzido por Galimberti et al. encontrou aumento de metilação da região promotora de GRN em pacientes com DFT esporádica, em relação a um grupo controle. Esse mecanismo epigenético de silenciamento da expressão gênica estava inversamente correlacionado com os níveis de RNA mensageiro de $G R N$ no sangue. No entanto, o aumento de metilação não se traduziu em diferenças nos níveis de progranulina plasmática entre o grupo de pacientes com DFT esporádica e o grupo controle. ${ }^{386}$

É importante salientar que a dosagem de progranulina no plasma é útil na identificação de mutações nulas de GRN. Em mutações missense patogênicas, no entanto, os níveis de progranulina tendem a ser intermediários entre os níveis observados nas mutações nulas e os encontrados em controles saudáveis. ${ }^{154,155} \mathrm{~A}$ sobreposição de valores limita a utilização da mensuração de progranulina no plasma 
como método de rastreio de mutações missense em GRN, porém essas mutações são infrequentes (e não foram observadas na amostra deste estudo).

Mutação em MAPT. A mutação MAPT p.N279K encontrada no probando DFT 17 já foi descrita em outras famílias. Essa mutação missense está localizada no éxon 10 de MAPT, em uma sequência ESE (do inglês, exonic splicing enhancer) rica em purinas, que promove o splicing to éxon 10. Experimentos in vitro indicaram que a mutação aumenta a ligação de proteínas ricas em serina/arginina, como a Tra2 $\beta$, o que reforça o elemento ESE. Com isso, há aumento da inclusão do éxon 10 no RNA mensageiro, e consequentemente aumento da formação de tau 4R. ${ }^{387,388 ~ E m ~}$ camundongos transgênicos que expressavam a proteína tau humana com a mutação N279K, Dawson et al. observaram não apenas aumento da inclusão do éxon 10 em RNA mensageiro e proteína, mas também sintomas motores e cognitivos associados a acúmulo de tau patologicamente fosforilada em neurônios e astrócitos, e degeneração de vias dopaminérgicas. ${ }^{389}$

Em 1992, Wszolek et al. descreveram uma família norte-americana com um fenótipo caracterizado por parkinsonismo, distonia, demência, sinais piramidais e alterações da motricidade ocular, que denominaram de degeneração pálido-pontonigral. ${ }^{390}$ Seis anos após o relato inicial, Clark et al. identificaram nessa família a mutação MAPT p.N279K. ${ }^{391}$ A mesma mutação foi identificada em outras famílias previamente descritas no Japão (uma família inicialmente diagnosticada com degeneração pálido-nigro-luysiana, e outra caracterizada com DFT e parkinsonismo) e na França (uma família com demência e paralisia supranuclear). ${ }^{392}$ Posteriormente, outra família foi descrita na Itália, e outros probandos foram identificados no Japão. ${ }^{192,393}$ Apesar de ter sido identificada em diversas partes do mundo, a mutação parece ser particularmente frequente no Japão. Em uma casuística japonesa publicada recentemente, dos seis probandos identificados com mutação em MAPT, quatro apresentavam a mutação p.N279K. ${ }^{192}$

A idade média de início dos sintomas na mutação MAPT p.N279K é de 42,5 anos, com duração média de doença entre 6 a 8 anos. ${ }^{77,392}$ A apresentação clínica predominante é de um parkinsonismo rígido-acinético, associado a instabilidade postural, que pode ser parcialmente responsivo a levodopa nas fases iniciais da doença (como ocorreu com o paciente DFT 17). ${ }^{192,394}$ Paralisia supranuclear do olhar 
e apraxia da abertura e/ou fechamento ocular podem aparecer. Tremores assimétricos, distonia e sinais de liberação piramidal são outros sintomas motores descritos em pacientes com esta mutação. ${ }^{392,394}$

As manifestações comportamentais podem variar desde alterações leves como irritabilidade a sintomas como os observados na vcDFT. As alterações cognitivas podem ser precoces, e um estudo relatou redução de fluência verbal fonêmica até dois anos antes do aparecimento de sintomas motores. ${ }^{395}$ Quase que invariavelmente os pacientes acabam desenvolvendo um quadro demencial, e nas fases finais da doença, evoluem com mutismo. 394

Os pacientes com a mutação mais frequentemente recebem diagnóstico de PSP, mas também podem ser diagnosticados com SCB ou vcDFT. ${ }^{192,396}$ O paciente DFT 17 foi inicialmente diagnosticado com vcDFT com parkinsonismo, mas como posteriormente desenvolveu alterações da motricidade ocular extrínseca e apraxia do fechamento ocular, associado a piora progressiva do quadro parkinsoniano, o fenótipo foi se tornando mais compatível com PSP.

A neuroimagem estrutural do probando DFT17 (Figura 26) mostrava atrofia predominante em região temporal medial. Esse é um achado incomum em casos de vcDFT, mas é consistente com um estudo de Whitwell et al., que demonstrou que mutações que afetam o splicing alternativo do éxon 10 (como é o caso da mutação MAPT p.N279K) tendem a apresentar maior atrofia de substância cinzenta nos lobos temporais mediais. ${ }^{105}$ Arvanitakis et al. também observaram que atrofia e hipometabolismo predominam nos lobos temporais mediais, que são as áreas mais precocemente afetadas nesta mutação. ${ }^{397}$

O probando DFT 17 faleceu após seis anos de sintomas, e não foi realizado estudo neuropatológico. Em casos de DLFT com a mutação MAPT p.N279K publicados na literatura, foram descritos emaranhados neurofibrilares em neurônios e emaranhados em células da glia que continham apenas a isoforma $4 \mathrm{R}$ da tau. ${ }^{75,398}$

Variantes não patogênicas em GRN e MAPT. Dentre as cinco variantes encontradas em região codificadora de GRN, quatro são silenciosas (p.D33, p.G93, p.D128, e p.T506). Uma variante missense (p.R19W) foi encontrada em dois indivíduos do grupo controle e é sabidamente não patogênica, com escore no Polyphen-2 de 0,003 (benigna). ${ }^{77,399}$ 
As três variantes encontradas em MAPT (p.A227, p.N255, e p.P270) são silenciosas, ${ }^{77}$ e foram identificadas tanto em indivíduos do grupo controle quanto do grupo DFT. As variantes p.A227 e p.N255 parecem estar em alto desequilíbrio de ligação, pois sempre foram encontradas em associação.

DFT familial sem mutação identificada. Dentre os 15 probandos com antecedente familiar de DFT, em apenas seis (40\%) a mutação causadora foi identificada em MAPT ou GRN. Em um outro probando (DFT 46), diagnosticado com vsAPP, foi previamente identificada uma mutação p.I383V no gene TARDBP.244 Resta, portanto, a identificação da mutação causadora em mais de $50 \%$ dos casos familiais de DFT desta casuística. É provável que alguns desses casos apresentem expansões de hexanucleotídeos no gene C9orf72, que junto com mutações em MAPT e GRN, são as causas mais frequentes de DFT monogênica. ${ }^{45,78}$ É possível também que alguns desses probandos tenham mutações em alguns dos outros genes associados a DLFT mencionados na introdução. Outra possibilidade é que mutações em genes não relacionados a DLFT, mas que podem se apresentar com o fenótipo de vcDFT, expliquem alguns desses casos familiares. De fato, mutações nos genes PSEN1 (presenilina 1) e PSEN2 (presenilina 2), que causam DA autossômica dominante, já foram encontradas em famílias com fenótipo de vcDFT. ${ }^{400-404}$ Demência com características frontotemporais também já foi descrita em mutações do gene da proteína priônica (PRNP), como a p.T183A, ${ }^{405}$ e uma duplicação do locus do gene da a-sinucleína (SNCA) foi recentemente descrita em uma família cuja apresentação clínica era semelhante à vcDFT com parkinsonismo, mas que no exame neuropatológico apresentava características de sinucleinopatia. ${ }^{406}$

Apesar dessas possibilidades, uma parcela significativa desses probandos podem não ter mutações nos genes atualmente conhecidos como causadores de doenças neurodegenerativas, como mostraram alguns centros de pesquisa em DFT. Na casuística de Flandres, na Bélgica, em 62\% dos casos de DFT familial e 14\% dos casos de DFT-ELA familial não foram encontradas mutações nos genes MAPT, GRN, C9orf72, VCP, CHMP2B, ou PSEN1, indicando que mutações em outros genes ainda não identificados também devem causar DFT. ${ }^{56} \mathrm{Na}$ casuística da rede francesa de pesquisa em DLFT/DLFT-ELA, 58,5\% dos probandos com vcDFT familial e 31,2\% dos probandos com DFT-ELA familial não apresentavam mutações nos genes C9orf72, 
GRN, MAPT, VCP, TARDBP, ou FUS. ${ }^{78} \mathrm{Na}$ Austrália, um grupo identificou mutações em MAPT, GRN ou C9orf72 em apenas 47\% dos casos de DFT que tinham escore de Goldman modificado entre 1 e 3 (que indicaria história familiar "forte"). ${ }^{51}$

A utilização de tecnologias de sequenciamento de segunda geração para sequenciamento de painéis de genes, ou mesmo de exomas ou genomas completos, pode ser útil para identificação de mutações patogênicas em demências familiais. Beck et al. utilizaram o sequenciador lon Torrent $P G M{ }^{\circledR}$ para identificar mutações em um painel de 17 genes associados a doenças neurodegenerativas (como PSEN1, PSEN2, APP, GRN, MAPT, CHMP2B, TARDBP, FUS, VCP, PRNP, entre outros), em amostras de DNA de 85 pacientes. ${ }^{407}$ Com isso, encontraram sensibilidade de $96,5 \%$ e especificidade de $100 \%$ para identificação de mutações e polimorfismos. Algumas das principais limitações do método residem na identificação de variações de números de cópias (como duplicação de gene) ou de expansões de repetições (como a de hexanucleotídeos do gene C9orf72). A despeito dessa limitação, as tecnologias de sequenciamento de segunda geração podem ser úteis para a investigação de formas familiais de DFT (ou mesmo de outras demências degenerativas), particularmente quando se considera que os custos desse método têm caído progressivamente ao longo dos anos. 408

Considerações finais. A identificação de mutações em famílias com DFT tem grandes implicações para as famílias acometidas, não apenas para os pacientes que já desenvolveram sintomas, mas também para os descendentes diretos desses pacientes.

Com a identificação dos principais genes associados a DLFT, as pesquisas têm se voltado para caracterizar o estágio pré-sintomático da doença, com o intuito de se identificar biomarcadores que possam ser utilizados para avaliar resposta a terapêutica. Diversos estudos já foram conduzidos com as diferentes mutações, e identificaram manifestações cognitivas leves, alterações no metabolismo de glicose cerebral ou em neuroimagem estrutural, e/ou mudanças na conectividade funcional em indivíduos que apresentam mutações patogênicas mas ainda não desenvolveram sintomas. ${ }^{409-413}$ Recentemente Rohrer et al. publicaram um estudo multicêntrico em que compararam o desempenho cognitivo e a neuroimagem estrutural entre indivíduos pré-sintomáticos com mutação e indivíduos sem mutação, de famílias com 
DFT causada por mutações em MAPT, GRN ou C9orf72. Nesse estudo relataram diferenças no desempenho cognitivo em indivíduos pré-sintomáticos que podiam ser notadas até cinco anos antes no início esperado dos sintomas, além de atrofia cortical e subcortical regional que foi observada pelo menos dez anos antes do início esperado de sintomas. Em indivíduos com mutações em MAPT, atrofia no hipocampo e amígdala foi observada 15 anos antes do início dos sintomas; em indivíduos com mutações em GRN, atrofia na ínsula foi detectada dez anos antes do início previsto dos sintomas; e em expansões de C9orf72, atrofia de estruturas com tálamo, ínsula e áreas corticais posteriores parece se iniciar 25 anos antes do início previsto dos sintomas. ${ }^{414}$

O objetivo maior das pesquisas em indivíduos pré-sintomáticos e sintomáticos com as formas monogênicas de DFT (e outras doenças neurodegenerativas monogênicas) é o desenvolvimento de tratamentos que modifiquem a evolução da doença, ou mesmo impeçam o seu aparecimento. Dentre as mutações associadas a DFT, a descoberta de tratamentos para as mutações no gene da progranulina parece ser a mais promissora. Como as mutações em GRN causam doença por haploinsuficiência, algumas estratégias têm sido testadas para aumentar a expressão (como o uso de inibidores de histona deacetilase) ou secreção da proteína (com o uso de medicações que aumentam a excreção, como amiodarona). ${ }^{316}$ Um ensaio clínico multicêntrico de fase dois com um inibidor de histona deacetilase denominado FRM0334 em indivíduos com mutações em GRN está em andamento (Clinicaltrials.gov NCT02149160). ${ }^{415}$

O aumento da expressão de progranulina também pode ser de interesse para o tratamento da DA. Recentemente, um grupo demonstrou que em camundongos transgênicos com DA, a redução da expressão de progranulina na micróglia foi associada a aumento da presença de placas de amiloide $\beta$ e a exacerbação de déficits cognitivos, enquanto que o aumento da expressão de progranulina reduziu a carga de placas de amiloide $\beta$, além de diminuir déficits de memória espacial e perda de neurônios hipocampais. ${ }^{416}$ Os achados desse estudo indicam que a progranulina pode proteger contra a toxicidade causada pelo amilóide $\beta$, e sugerem que aumentar a expressão de progranulina pode ser um possível tratamento também para a DA.

Para as doenças causadas por expansões de MAPT e C9orf72, as pesquisas ainda estão em fase pré-clínica. Os ensaios clínicos conduzidos até o momento em 
taupatias não apresentaram resultados positivos, mas em ratos transgênicos com mutação em MAPT, a injeção intracerebral de vetores (lentivirus) com moléculas de RNA desenvolvidas para afetar o splicing alternativo (SMaRT, spliceosome-mediated RNA trans-splicing) podem permitir a reprogramação do splicing de modo a aumentar ou reduzir a inclusão do éxon 10 no transcrito. ${ }^{316,417}$ Recentemente, Donnelly et al. demonstraram que oligonucleotídeos antisense que se ligam a RNA com repetições de GGGGCC foram capazes de reduzir o acúmulo RNAs e proteínas no núcleo, além de reduzir a susceptibilidade a excitotoxicidade causada por glutamato, em neurônios com a expansão em C9orf72 derivados de células-tronco pluripotentes induzidas. ${ }^{169}$ 


\section{CONCLUSÕES}

A frequência de mutações patogênicas em GRN nesta casuística de 62 probandos com DFT foi de 9,6\%, e a de mutações em MAPT foi de 1,6\%. Entre casos familiais de DFT, a frequência de mutações em GRN foi de 33,3\%, e em MAPT foi de $6,7 \%$. Não foram identificadas mutações nesses genes nos casos esporádicos de DFT. As mutações encontradas em GRN são do tipo nonsense ou frameshift, enquanto que em MAPT, a mutação é missense.

Mutações nulas em GRN foram encontradas em seis probandos da casuística. Duas das mutações - GRN p.Q130X e p.D317Afs*11 - não foram ainda descritas na literatura. As outras mutações (p.V200Gfs*18, p.Q257Pfs²6, p.Q300X, e p.S301Cfs ${ }^{*} 60$ ) já foram descritas. ${ }^{357,362} \mathrm{~A}$ idade de início dos sintomas nos probandos variou entre 44 e 64 anos, e os diagnósticos clínicos foram de vnfAPP e vcDFT. Algumas características previamente relatadas em casuísticas de pacientes com mutações em GRN também foram observadas neste estudo, tais como: variabilidade na apresentação clínica mesmo dentro de uma mesma família, e presença de distúrbio precoce de memória episódica em alguns casos. Um dos probandos (DFT 63) foi submetido a estudo neuropatológico, e os achados foram compatíveis com DLFT-TDP tipo $A$, que é o padrão tipicamente observado nas mutações de $G R N .{ }^{44}$

A dosagem plasmática de progranulina permitiu a identificação das mutações nulas em GRN com $100 \%$ de sensibilidade e especificidade, e portanto foi marcador adequado das mutações de GRN nesta casuística. O nível de corte de $70 \mathrm{ng} / \mathrm{ml}$ encontrado neste estudo é similar ao apresentado por dois outros estudos. ${ }^{154,382}$ No entanto, a grande variabilidade de valores apresentados por estudos diferentes, mesmo utilizando um kit de ELISA produzido pelo mesmo fabricante, indica que se deve ter cautela ao transpor este ponto de corte para outras casuísticas.

Uma mutação em MAPT (p.N279K) foi identificada em um paciente com DFT familial. Esse paciente foi inicialmente diagnosticado com vcDFT com parkinsonismo, mas posteriormente evoluiu com sintomas sugestivos de PSP. Assim como o probando DFT 17, os pacientes com a mutação MAPT p.N279K mais frequentemente recebem diagnóstico clínico de PSP, e nos exames de neuroimagem apresentam comprometimento predominante nos lobos temporais mesiais. ${ }^{394,397}$ 


\section{REFERÊNCIAS BIBLIOGRÁFICAS}

1. Neary D, Snowden JS, Gustafson L, Passant U, Stuss D, Black S, et al. Frontotemporal lobar degeneration: a consensus on clinical diagnostic criteria. Neurology. 1998;51(6):1546-1554.

2. Gorno-Tempini ML, Hillis AE, Weintraub S, Kertesz A, Mendez M, Cappa SF, et al. Classification of primary progressive aphasia and its variants. Neurology. 2011;76(11):1006-1014.

3. Rascovsky K, Hodges JR, Knopman D, Mendez MF, Kramer JH, Neuhaus J, et al. Sensitivity of revised diagnostic criteria for the behavioural variant of frontotemporal dementia. Brain. 2011;134(Pt 9):2456-2477.

4. Spatt J. Arnold Pick's concept of dementia. Cortex. 2003;39(3):525-531.

5. Mesulam MM. Slowly progressive aphasia without generalized dementia. Ann Neurol. 1982;11(6):592-598.

6. Mesulam MM, Weintraub S. Spectrum of primary progressive aphasia. Baillieres Clin Neurol. 1992;1(3):583-609.

7. Snowden JS, Goulding P, Neary D. Semantic dementia: A form of circumscribed cerebral atrophy. Behav Neurol. 1989;2(3)167-82.

8. Turner RS, Kenyon LC, Trojanowski JQ, Gonatas N, Grossman M. Clinical, neuroimaging, and pathologic features of progressive nonfluent aphasia. Ann Neurol. 1996;39(2):166-173.

9. Gorno-Tempini ML, Dronkers NF, Rankin KP, Ogar JM, Phengrasamy L, Rosen $\mathrm{HJ}$, et al. Cognition and anatomy in three variants of primary progressive aphasia. Ann Neurol. 2004;55(3):335-346.

10. Ratnavalli E, Brayne C, Dawson K, Hodges JR. The prevalence of frontotemporal dementia. Neurology. 2002;58(11):1615-1621.

11. Harvey RJ, Skelton-Robinson M, Rossor MN. The prevalence and causes of dementia in people under the age of 65 years. J Neurol Neurosurg Psychiatry. 2003;74(9):1206-1209. 
12. Fujihara S, Brucki SM, Rocha MS, Carvalho AA, Piccolo AC. Prevalence of presenile dementia in a tertiary outpatient clinic. Arq Neuropsiquiatr. 2004;62(3A):592-595.

13. Yokota O, Sasaki K, Fujisawa Y, Takahashi J, Terada S, Ishihara T, et al. Frequency of early and late-onset dementias in a Japanese memory disorders clinic. Eur J Neurol. 2005;12(10):782-790.

14. Papageorgiou SG, Kontaxis T, Bonakis A, Kalfakis N, Vassilopoulos D. Frequency and causes of early-onset dementia in a tertiary referral center in Athens. Alzheimer Dis Assoc Disord. 2009;23(4):347-351.

15. Knopman DS, Roberts RO. Estimating the number of persons with frontotemporal lobar degeneration in the US population. $J \mathrm{Mol}$ Neurosci. 2011;45(3):330-335.

16. Rabinovici GD, Rascovsky K, Miller BL. Frontotemporal lobar degeneration: clinical and pathologic overview. Handb Clin Neurol. 2008;89:343-364.

17. van Swieten JC, Rosso SM. Epidemiological aspects of frontotemporal dementia. Handb Clin Neurol. 2008;89:331-341.

18. Hodges JR, Davies R, Xuereb J, Kril J, Halliday G. Survival in frontotemporal dementia. Neurology. 2003;61(3):349-354.

19. Josephs KA, Knopman DS, Whitwell JL, Boeve BF, Parisi JE, Petersen RC, et al. Survival in two variants of tau-negative frontotemporal lobar degeneration: FTLD-U vs FTLD-MND. Neurology. 2005;65(4):645-647.

20. Johnson JK, Diehl J, Mendez MF, Neuhaus J, Shapira JS, Forman M, et al. Frontotemporal lobar degeneration: demographic characteristics of 353 patients. Arch Neurol. 2005;62(6):925-930.

21. Kertesz A, McMonagle P, Blair M, Davidson W, Munoz DG. The evolution and pathology of frontotemporal dementia. Brain. 2005;128(Pt 9):1996-2005.

22. Forman MS, Farmer J, Johnson JK, Clark CM, Arnold SE, Coslett HB, et al. Frontotemporal dementia: clinicopathological correlations. Ann Neurol. 2006;59(6):952-962.

23. Porto CS, Bahia VS, Brucki SMD, Caramelli P, Nitrini R. Neuropsychological differences between frontotemporal lobar degeneration and Alzheimer's disease. Dement Neuropsychol. 2008;2:223-227. 
24. Le Ber I, Guedj E, Gabelle A, Verpillat P, Volteau M, Thomas-Anterion C, et al. Demographic, neurological and behavioural characteristics and brain perfusion SPECT in frontal variant of frontotemporal dementia. Brain. 2006;129(Pt 11):3051-3065.

25. Lillo P, Hodges JR. Frontotemporal dementia and motor neurone disease: overlapping clinic-pathological disorders. J Clin Neurosci. 2009;16(9):11311135.

26. Piguet O, Hornberger M, Shelley BP, Kipps CM, Hodges JR. Sensitivity of current criteria for the diagnosis of behavioral variant frontotemporal dementia. Neurology. 2009;72(8):732-737.

27. Balasa M, Gelpi E, Martin I, Antonell A, Rey M, Grau-Rivera O, et al. Diagnostic accuracy of FTDC behavioral variant frontotemporal dementia criteria in a clinicopathological cohort. Neuropathol Appl Neurobiol. 2014. [Epub ahead of print]

28. Harris JM, Gall C, Thompson JC, Richardson AM, Neary D, du Plessis D, et al. Sensitivity and specificity of FTDC criteria for behavioral variant frontotemporal dementia. Neurology. 2013;80(20):1881-1887.

29. Lamarre AK, Rascovsky K, Bostrom A, Toofanian P, Wilkins S, Sha SJ, et al. Interrater reliability of the new criteria for behavioral variant frontotemporal dementia. Neurology. 2013;80(21):1973-1977.

30. Foster NL, Heidebrink JL, Clark CM, Jagust WJ, Arnold SE, Barbas NR, et al. FDG-PET improves accuracy in distinguishing frontotemporal dementia and Alzheimer's disease. Brain. 2007;130(Pt 10):2616-2635.

31. Pereira JM, Williams GB, Acosta-Cabronero J, Pengas G, Spillantini MG, Xuereb $\mathrm{JH}$, et al. Atrophy patterns in histologic vs clinical groupings of frontotemporal lobar degeneration. Neurology. 2009;72(19):1653-1660.

32. Krueger CE, Dean DL, Rosen HJ, Halabi C, Weiner M, Miller BL, et al. Longitudinal rates of lobar atrophy in frontotemporal dementia, semantic dementia, and Alzheimer's disease. Alzheimer Dis Assoc Disord. 2010;24(1):43-48.

33. Seeley WW. Anterior insula degeneration in frontotemporal dementia. Brain Struct Funct. 2010;214(5-6):465-475. 
34. Hodges JR, Patterson K. Semantic dementia: a unique clinicopathological syndrome. Lancet Neurol. 2007;6(11):1004-1014.

35. Chan D, Anderson V, Pijnenburg Y, Whitwell J, Barnes J, Scahill R, et al. The clinical profile of right temporal lobe atrophy. Brain. 2009;132(Pt 5):1287-1298.

36. Josephs KA, Whitwell JL, Knopman DS, Boeve BF, Vemuri P, Senjem ML, et al. Two distinct subtypes of right temporal variant frontotemporal dementia. Neurology. 2009;73(18):1443-1450.

37. Grossman M. Primary progressive aphasia: clinicopathological correlations. Nat Rev Neurol. 2010;6(2):88-97.

38. Grossman M. The non-fluent/agrammatic variant of primary progressive aphasia. Lancet Neurol. 2012;11(6):545-555.

39. Rabinovici GD, Miller BL. Frontotemporal lobar degeneration: epidemiology, pathophysiology, diagnosis and management. CNS Drugs. 2010;24(5):375398.

40. Mackenzie IR, Neumann M, Bigio EH, Cairns NJ, Alafuzoff I, Kril J, et al. Nomenclature and nosology for neuropathologic subtypes of frontotemporal lobar degeneration: an update. Acta Neuropathol. 2010;119(1):1-4.

41. Josephs KA, Hodges JR, Snowden JS, Mackenzie IR, Neumann M, Mann DM, et al. Neuropathological background of phenotypical variability in frontotemporal dementia. Acta Neuropathol. 2011;122(2):137-153.

42. Urwin H, Josephs KA, Rohrer JD, Mackenzie IR, Neumann M, Authier A, et al. FUS pathology defines the majority of tau- and TDP-43-negative frontotemporal lobar degeneration. Acta Neuropathol. 2010;120(1):33-41.

43. Seelaar H, Klijnsma KY, de Koning I, van der Lugt A, Chiu WZ, Azmani A, et al. Frequency of ubiquitin and FUS-positive, TDP-43-negative frontotemporal lobar degeneration. J Neurol. 2010;257(5):747-753.

44. Mackenzie IR, Neumann M, Baborie A, Sampathu DM, Du Plessis D, Jaros E, et al. A harmonized classification system for FTLD-TDP pathology. Acta Neuropathol. 2011;122(1):111-113.

45. Cohn-Hokke PE, Elting MW, Pijnenburg YA, van Swieten JC. Genetics of dementia: update and guidelines for the clinician. Am $J$ Med Genet $B$ Neuropsychiatr Genet. 2012;159B(6):628-643. 
46. Stevens M, van Duijn CM, Kamphorst W, de Knijff $P$, Heutink P, van Gool WA, et al. Familial aggregation in frontotemporal dementia. Neurology. 1998;50(6):1541-1545.

47. Goldman JS, Farmer JM, Wood EM, Johnson JK, Boxer A, Neuhaus J, et al. Comparison of family histories in FTLD subtypes and related tauopathies. Neurology. 2005;65(11):1817-1819.

48. Rohrer JD, Guerreiro R, Vandrovcova J, Uphill J, Reiman D, Beck J, et al. The heritability and genetics of frontotemporal lobar degeneration. Neurology. 2009;73(18):1451-1456.

49. Seelaar H, Kamphorst W, Rosso SM, Azmani A, Masdjedi R, de Koning I, et al. Distinct genetic forms of frontotemporal dementia. Neurology. 2008;71(16):1220-1226.

50. Borroni B, Alberici A, Grassi M, Turla M, Zanetti O, Bianchetti A, et al. Is frontotemporal lobar degeneration a rare disorder? Evidence from a preliminary study in Brescia county, Italy. J Alzheimers Dis. 2010;19(1):111-116.

51. Po K, Leslie FV, Gracia N, Bartley L, Kwok JB, Halliday GM, et al. Heritability in frontotemporal dementia: more missing pieces? J Neurol. 2014;261(11):21702177.

52. Hutton $\mathrm{M}$, Lendon $\mathrm{CL}$, Rizzu $\mathrm{P}$, Baker $\mathrm{M}$, Froelich $\mathrm{S}$, Houlden $\mathrm{H}$, et al. Association of missense and 5'-splice-site mutations in tau with the inherited dementia FTDP-17. Nature. 1998;393(6686):702-705.

53. Baker M, Mackenzie IR, Pickering-Brown SM, Gass J, Rademakers R, Lindholm $\mathrm{C}$, et al. Mutations in progranulin cause tau-negative frontotemporal dementia linked to chromosome 17. Nature. 2006;442(7105):916-919.

54. DeJesus-Hernandez M, Mackenzie IR, Boeve BF, Boxer AL, Baker M, Rutherford NJ, et al. Expanded GGGGCC hexanucleotide repeat in noncoding region of C9ORF72 causes chromosome 9p-linked FTD and ALS. Neuron. 2011;72(2):245-256.

55. Renton AE, Majounie E, Waite A, Simon-Sanchez J, Rollinson S, Gibbs JR, et al. A hexanucleotide repeat expansion in C9ORF72 is the cause of chromosome 9p21-linked ALS-FTD. Neuron. 2011;72(2):257-268. 
56. Gijselinck I, Van Langenhove T, van der Zee J, Sleegers K, Philtjens S, Kleinberger G, et al. A C9orf72 promoter repeat expansion in a FlandersBelgian cohort with disorders of the frontotemporal lobar degenerationamyotrophic lateral sclerosis spectrum: a gene identification study. Lancet Neurol. 2012;11(1):54-65.

57. Van Langenhove T, van der Zee J, Van Broeckhoven C. The molecular basis of the frontotemporal lobar degeneration-amyotrophic lateral sclerosis spectrum. Ann Med. 2012;44(8):817-828.

58. Ling SC, Polymenidou M, Cleveland DW. Converging mechanisms in ALS and FTD: disrupted RNA and protein homeostasis. Neuron. 2013;79(3):416-438.

59. Benatar M, Wuu J, Fernandez C, Weihl CC, Katzen H, Steele J, et al. Motor neuron involvement in multisystem proteinopathy: implications for ALS. Neurology. 2013;80(20):1874-1880.

60. Nalbandian A, Donkervoort S, Dec E, Badadani M, Katheria V, Rana P, et al. The multiple faces of valosin-containing protein-associated diseases: inclusion body myopathy with Paget's disease of bone, frontotemporal dementia, and amyotrophic lateral sclerosis. J Mol Neurosci. 2011;45(3):522-531.

61. Ferrari R, Hernandez DG, Nalls MA, Rohrer JD, Ramasamy A, Kwok JB, et al. Frontotemporal dementia and its subtypes: a genome-wide association study. Lancet Neurol. 2014;13(7):686-699.

62. van der Zee J, Van Broeckhoven C. TMEM106B a novel risk factor for frontotemporal lobar degeneration. J Mol Neurosci. 2011;45(3):516-521.

63. Takada LT, Bahia VS, Nitrini R, Yokoyama JS, Miller BL, Fong JC, et al. Frontotemporal dementia due to C9orf72 and GRN mutations: report of two Brazilian kindreds (poster). Abstract presented at I Latin American and III Brazilian Symposium on Frontotemporal Lobar Degeneration (FTLD); June 1416, 2012, 2012; São Paulo, Brasil.

64. Takada LT, Pimentel ML, Dejesus-Hernandez M, Fong JC, Yokoyama JS, Karydas A, et al. Frontotemporal dementia in a Brazilian kindred with the c9orf72 mutation. Arch Neurol. 2012;69(9):1149-1153.

65. Fanganiello RD, Kimonis VE, Corte CC, Nitrini R, Passos-Bueno MR. A Brazilian family with hereditary inclusion body myopathy associated with Paget disease of bone and frontotemporal dementia. Braz $J$ Med Biol Res. 2011;44(4):374-380. 
66. Munoz DG, Ferrer I. Neuropathology of hereditary forms of frontotemporal dementia and parkinsonism. Handb Clin Neurol. 2008;89:393-414.

67. Goedert M. Tau gene mutations and their effects. Mov Disord. 2005;20 Suppl 12:S45-52.

68. Rademakers $R$, Cruts $M$, van Broeckhoven $C$. The role of tau (MAPT) in frontotemporal dementia and related tauopathies. Hum Mutat. 2004;24(4):277295.

69. Spillantini MG, Goedert M. Tau pathology and neurodegeneration. Lancet Neurol. 2013;12(6):609-622.

70. Josephs KA. Frontotemporal dementia and related disorders: deciphering the enigma. Ann Neurol. 2008;64(1):4-14.

71. Chen J, Kanai Y, Cowan NJ, Hirokawa N. Projection domains of MAP2 and tau determine spacings between microtubules in dendrites and axons. Nature. 1992;360(6405):674-677.

72. Brandt R, Leger J, Lee G. Interaction of tau with the neural plasma membrane mediated by tau's amino-terminal projection domain. $J$ Cell Biol. 1995;131(5):1327-1340.

73. Pickering-Brown S, Hutton M. The genetics of frontotemporal dementia. Handb Clin Neurol. 2008;89:383-392.

74. Khlistunova I, Biernat J, Wang Y, Pickhardt M, von Bergen M, Gazova Z, et al. Inducible expression of Tau repeat domain in cell models of tauopathy: aggregation is toxic to cells but can be reversed by inhibitor drugs. $J$ Biol Chem. 2006;281(2):1205-1214.

75. Ghetti B, Oblak AL, Boeve BF, Johnson KA, Dickerson BC, Goedert M. Frontotemporal Dementia Caused by MAPT mutations: A chameleon for neuropathology and neuroimaging. Neuropathol App/ Neurobiol. 2015;41(1):2446.

76. Goedert M, Spillantini MG. Pathogenesis of the tauopathies. J Mol Neurosci. 2011;45(3):425-431.

77. Cruts M, Theuns J, Van Broeckhoven C. Locus-specific mutation databases for neurodegenerative brain diseases. Hum Mutat. 2012;33(9):1340-1344. 
78. Le Ber I, Camuzat A, Guillot-Noel L, Hannequin D, Lacomblez L, Golfier V, et al. C9ORF72 repeat expansions in the frontotemporal dementias spectrum of diseases: a flow-chart for genetic testing. J Alzheimers Dis. 2013;34(2):485499.

79. Van Langenhove T, van der Zee J, Gijselinck I, Engelborghs S, Vandenberghe $\mathrm{R}$, Vandenbulcke $\mathrm{M}$, et al. Distinct clinical characteristics of C9orf72 expansion carriers compared with GRN, MAPT, and nonmutation carriers in a FlandersBelgian FTLD cohort. JAMA Neurol. 2013;70(3):365-373.

80. Pickering-Brown SM, Rollinson S, Du Plessis D, Morrison KE, Varma A, Richardson AM, et al. Frequency and clinical characteristics of progranulin mutation carriers in the Manchester frontotemporal lobar degeneration cohort: comparison with patients with MAPT and no known mutations. Brain. 2008;131(Pt 3):721-731.

81. Boeve BF, Boylan KB, Graff-Radford NR, DeJesus-Hernandez M, Knopman DS, Pedraza $O$, et al. Characterization of frontotemporal dementia and/or amyotrophic lateral sclerosis associated with the GGGGCC repeat expansion in C9ORF72. Brain. 2012;135(Pt 3):765-783.

82. Poorkaj P, Grossman M, Steinbart E, Payami H, Sadovnick A, Nochlin D, et al. Frequency of tau gene mutations in familial and sporadic cases of nonAlzheimer dementia. Arch Neurol. 2001;58(3):383-387.

83. Beck J, Rohrer JD, Campbell T, Isaacs A, Morrison KE, Goodall EF, et al. A distinct clinical, neuropsychological and radiological phenotype is associated with progranulin gene mutations in a large UK series. Brain. 2008;131(Pt 3):706720.

84. Gass J, Cannon A, Mackenzie IR, Boeve B, Baker M, Adamson J, et al. Mutations in progranulin are a major cause of ubiquitin-positive frontotemporal lobar degeneration. Hum Mol Genet. 2006;15(20):2988-3001.

85. Mahoney CJ, Beck J, Rohrer JD, Lashley T, Mok K, Shakespeare T, et al. Frontotemporal dementia with the C9ORF72 hexanucleotide repeat expansion: clinical, neuroanatomical and neuropathological features. Brain. 2012;135(Pt 3):736-750.

86. Boeve BF. Progress on progranulin. Arch Neurol. 2010;67(2):145-147. 
87. Hayashi S, Toyoshima Y, Hasegawa M, Umeda Y, Wakabayashi K, Tokiguchi $\mathrm{S}$, et al. Late-onset frontotemporal dementia with a novel exon 1 (Arg5His) tau gene mutation. Ann Neurol. 2002;51(4):525-530.

88. van Swieten J, Spillantini MG. Hereditary frontotemporal dementia caused by Tau gene mutations. Brain Pathol. 2007;17(1):63-73.

89. Boeve BF, Hutton M. Refining frontotemporal dementia with parkinsonism linked to chromosome 17: introducing FTDP-17 (MAPT) and FTDP-17 (PGRN). Arch Neurol. 2008;65(4):460-464.

90. Donker Kaat L, Boon AJ, Azmani A, Kamphorst W, Breteler MM, Anar B, et al. Familial aggregation of parkinsonism in progressive supranuclear palsy. Neurology. 2009;73(2):98-105.

91. Rohrer JD, Paviour D, Vandrovcova J, Hodges J, de Silva R, Rossor MN. Novel L284R MAPT mutation in a family with an autosomal dominant progressive supranuclear palsy syndrome. Neurodegener Dis. 2011;8(3):149-152.

92. Ishizuka T, Nakamura M, Ichiba M, Sano A. Familial semantic dementia with P301L mutation in the Tau gene. Dement Geriatr Cogn Disord. 2011;31(5):334340.

93. Rossi G, Marelli C, Farina L, Laura M, Maria Basile A, Ciano C, et al. The G389R mutation in the MAPT gene presenting as sporadic corticobasal syndrome. Mov Disord. 2008;23(6):892-895.

94. Carney RM, Kohli MA, Kunkle BW, Naj AC, Gilbert JR, Zuchner S, et al. Parkinsonism and distinct dementia patterns in a family with the MAPT R406W mutation. Alzheimers Dement. 2014;10(3):360-5.

95. Doran M, du Plessis DG, Ghadiali EJ, Mann DM, Pickering-Brown S, Larner AJ. Familial early-onset dementia with tau intron $10+16$ mutation with clinical features similar to those of Alzheimer disease. Arch Neurol. 2007;64(10):15351539.

96. Lindquist SG, Holm IE, Schwartz M, Law I, Stokholm J, Batbayli M, et al. Alzheimer disease-like clinical phenotype in a family with FTDP-17 caused by a MAPT R406W mutation. Eur J Neurol. 2008;15(4):377-385.

97. Wojtas A, Heggeli KA, Finch N, Baker M, Dejesus-Hernandez M, Younkin SG, et al. C9ORF72 repeat expansions and other FTD gene mutations in a clinical 
AD patient series from Mayo Clinic. Am J Neurodegener Dis. 2012;1(1):107118.

98. Rossi G, Bastone A, Piccoli E, Morbin M, Mazzoleni G, Fugnanesi V, et al. Different mutations at V363 MAPT codon are associated with atypical clinical phenotypes and show unusual structural and functional features. Neurobiol Aging. 2014;35(2):408-417.

99. Whitwell JL, Jack CR, Jr., Boeve BF, Senjem ML, Baker M, Rademakers R, et al. Voxel-based morphometry patterns of atrophy in FTLD with mutations in MAPT or PGRN. Neurology. 2009;72(9):813-820.

100. Zarranz JJ, Ferrer I, Lezcano E, Forcadas MI, Eizaguirre B, Atares B, et al. A novel mutation (K317M) in the MAPT gene causes FTDP and motor neuron disease. Neurology. 2005;64(9):1578-1585.

101. Di Fonzo A, Ronchi D, Gallia F, Cribiu FM, Trezzi I, Vetro A, et al. Lower motor neuron disease with respiratory failure caused by a novel MAPT mutation. Neurology. 2014;82(22):1990-1998.

102. Nicholl DJ, Greenstone MA, Clarke CE, Rizzu P, Crooks D, Crowe A, et al. An English kindred with a novel recessive tauopathy and respiratory failure. Ann Neurol. 2003;54(5):682-686.

103. Rohrer JD, Ridgway GR, Modat M, Ourselin S, Mead S, Fox NC, et al. Distinct profiles of brain atrophy in frontotemporal lobar degeneration caused by progranulin and tau mutations. Neuroimage. 2010;53(3):1070-1076.

104. Whitwell JL, Weigand SD, Boeve BF, Senjem ML, Gunter JL, DeJesusHernandez $M$, et al. Neuroimaging signatures of frontotemporal dementia genetics: C9ORF72, tau, progranulin and sporadics. Brain. 2012;135(Pt 3):794806.

105. Whitwell JL, Jack CR, Jr., Boeve BF, Senjem ML, Baker M, Ivnik RJ, et al. Atrophy patterns in IVS10+16, IVS10+3, N279K, S305N, P301L, and V337M MAPT mutations. Neurology. 2009;73(13):1058-1065.

106. Whitwell JL, Jack CR, Jr., Parisi JE, Senjem ML, Knopman DS, Boeve BF, et al. Does TDP-43 type confer a distinct pattern of atrophy in frontotemporal lobar degeneration? Neurology. 2010;75(24):2212-2220. 
107. Caffrey TM, Joachim C, Paracchini S, Esiri MM, Wade-Martins R. Haplotypespecific expression of exon 10 at the human MAPT locus. Hum Mol Genet. 2006;15(24):3529-3537.

108. Trabzuni D, Wray S, Vandrovcova J, Ramasamy A, Walker R, Smith $C$, et al. MAPT expression and splicing is differentially regulated by brain region: relation to genotype and implication for tauopathies. Hum Mol Genet. 2012;21(18):40944103.

109. Donnelly MP, Paschou P, Grigorenko E, Gurwitz D, Mehdi SQ, Kajuna SL, et al. The distribution and most recent common ancestor of the 17q21 inversion in humans. Am J Hum Genet. 2010;86(2):161-171.

110. Baker M, Litvan I, Houlden H, Adamson J, Dickson D, Perez-Tur J, et al. Association of an extended haplotype in the tau gene with progressive supranuclear palsy. Hum Mol Genet. 1999;8(4):711-715.

111. Hoglinger GU, Melhem NM, Dickson DW, Sleiman PM, Wang LS, Klei L, et al. Identification of common variants influencing risk of the tauopathy progressive supranuclear palsy. Nat Genet. 2011;43(7):699-705.

112. Di Maria E, Tabaton M, Vigo T, Abbruzzese G, Bellone E, Donati C, et al. Corticobasal degeneration shares a common genetic background with progressive supranuclear palsy. Ann Neurol. 2000;47(3):374-377.

113. Elbaz A, Ross OA, loannidis JP, Soto-Ortolaza Al, Moisan F, Aasly J, et al. Independent and joint effects of the MAPT and SNCA genes in Parkinson disease. Ann Neurol. 2011;69(5):778-792.

114. Houlden H, Baker M, Morris HR, MacDonald N, Pickering-Brown S, Adamson $\mathrm{J}$, et al. Corticobasal degeneration and progressive supranuclear palsy share a common tau haplotype. Neurology. 2001;56(12):1702-1706.

115. Wider C, Vilarino-Guell C, Jasinska-Myga B, Heckman MG, Soto-Ortolaza AI, Cobb SA, et al. Association of the MAPT locus with Parkinson's disease. Eur $J$ Neurol. 2010;17(3):483-486.

116. Verpillat $\mathrm{P}$, Camuzat $\mathrm{A}$, Hannequin D, Thomas-Anterion C, Puel M, Belliard S, et al. Association between the extended tau haplotype and frontotemporal dementia. Arch Neurol. 2002;59(6):935-939. 
117. Hughes A, Mann D, Pickering-Brown S. Tau haplotype frequency in frontotemporal lobar degeneration and amyotrophic lateral sclerosis. Exp Neurol. 2003;181(1):12-16.

118. Short RA, Graff-Radford NR, Adamson J, Baker M, Hutton M. Differences in tau and apolipoprotein $\mathrm{E}$ polymorphism frequencies in sporadic frontotemporal lobar degeneration syndromes. Arch Neurol. 2002;59(4):611-615.

119. Sobrido MJ, Miller BL, Havlioglu N, Zhukareva V, Jiang Z, Nasreddine ZS, et al. Novel tau polymorphisms, tau haplotypes, and splicing in familial and sporadic frontotemporal dementia. Arch Neurol. 2003;60(5):698-702.

120. Abraham R, Sims R, Carroll L, Hollingworth P, O'Donovan MC, Williams J, et al. An association study of common variation at the MAPT locus with late-onset Alzheimer's disease. Am J Med Genet B Neuropsychiatr Genet. 2009;150B(8):1152-1155.

121. Gerrish A, Russo G, Richards A, Moskvina V, Ivanov D, Harold D, et al. The role of variation at AbetaPP, PSEN1, PSEN2, and MAPT in late onset Alzheimer's disease. J Alzheimers Dis. 2012;28(2):377-387.

122. Lee SE, Tartaglia MC, Yener G, Genc S, Seeley WW, Sanchez-Juan P, et al. Neurodegenerative disease phenotypes in carriers of MAPT p.A152T, a risk factor for frontotemporal dementia spectrum disorders and Alzheimer disease. Alzheimer Dis Assoc Disord. 2013;27(4):302-309.

123. Coppola G, Chinnathambi S, Lee JJ, Dombroski BA, Baker MC, Soto-Ortolaza $\mathrm{Al}$, et al. Evidence for a role of the rare p.A152T variant in MAPT in increasing the risk for FTD-spectrum and Alzheimer's diseases. Hum Mol Genet. 2012;21(15):3500-3512.

124. Cruts M, Gijselinck I, van der Zee J, Engelborghs S, Wils H, Pirici D, et al. Null mutations in progranulin cause ubiquitin-positive frontotemporal dementia linked to chromosome 17q21. Nature. 2006;442(7105):920-924.

125. Kleinberger G, Capell A, Haass C, Van Broeckhoven C. Mechanisms of granulin deficiency: lessons from cellular and animal models. Mol Neurobiol. 2013;47(1):337-360.

126. Nicholson AM, Gass J, Petrucelli L, Rademakers R. Progranulin axis and recent developments in frontotemporal lobar degeneration. Alzheimers Res Ther. 2012;4(1):4. 
127. Gijselinck I, Van Broeckhoven C, Cruts M. Granulin mutations associated with frontotemporal lobar degeneration and related disorders: an update. Hum Mutat. 2008;29(12):1373-1386.

128. Cruts $M$, Kumar-Singh S, Van Broeckhoven C. Progranulin mutations in ubiquitin-positive frontotemporal dementia linked to chromosome 17q21. Curr Alzheimer Res. 2006;3(5):485-491.

129. Gijselinck I, van der Zee J, Engelborghs S, Goossens D, Peeters K, Mattheijssens $\mathrm{M}$, et al. Progranulin locus deletion in frontotemporal dementia. Hum Mutat. 2008;29(1):53-58.

130. Rademakers R, Rovelet-Lecrux A. Recent insights into the molecular genetics of dementia. Trends Neurosci. 2009;32(8):451-461.

131. Clot F, Rovelet-Lecrux A, Lamari F, Noel S, Keren B, Camuzat A, et al. Partial deletions of the GRN gene are a cause of frontotemporal lobar degeneration. Neurogenetics. 2014;15(2):95-100.

132. Mukherjee O, Pastor P, Cairns NJ, Chakraverty S, Kauwe JS, Shears S, et al. HDDD2 is a familial frontotemporal lobar degeneration with ubiquitin-positive, tau-negative inclusions caused by a missense mutation in the signal peptide of progranulin. Ann Neurol. 2006;60(3):314-322.

133. Shankaran SS, Capell A, Hruscha AT, Fellerer K, Neumann M, Schmid B, et al. Missense mutations in the progranulin gene linked to frontotemporal lobar degeneration with ubiquitin-immunoreactive inclusions reduce progranulin production and secretion. J Biol Chem. 2008;283(3):1744-1753.

134. Wang J, Van Damme P, Cruchaga C, Gitcho MA, Vidal JM, Seijo-Martinez M, et al. Pathogenic cysteine mutations affect progranulin function and production of mature granulins. J Neurochem. 2010;112(5):1305-1315.

135. Yu CE, Bird TD, Bekris LM, Montine TJ, Leverenz JB, Steinbart E, et al. The spectrum of mutations in progranulin: a collaborative study screening 545 cases of neurodegeneration. Arch Neurol. 2010;67(2):161-170.

136. Bossu P, Salani F, Alberici A, Archetti S, Bellelli G, Galimberti D, et al. Loss of function mutations in the progranulin gene are related to pro-inflammatory cytokine dysregulation in frontotemporal lobar degeneration patients. $J$ Neuroinflammation. 2011;8:65. 
137. Miller ZA, Rankin KP, Graff-Radford NR, Takada LT, Sturm VE, Cleveland CM, et al. TDP-43 frontotemporal lobar degeneration and autoimmune disease. $J$ Neurol Neurosurg Psychiatry. 2013;84(9):956-962.

138. Benussi L, Ghidoni R, Pegoiani E, Moretti DV, Zanetti O, Binetti G. Progranulin Leu271Leufs X10 is one of the most common FTLD and CBS associated mutations worldwide. Neurobiol Dis. 2009;33(3):379-385.

139. Rademakers R, Baker M, Gass J, Adamson J, Huey ED, Momeni P, et al. Phenotypic variability associated with progranulin haploinsufficiency in patients with the common 1477C-->T (Arg493X) mutation: an international initiative. Lancet Neurol. 2007;6(10):857-868.

140. Chen-Plotkin AS, Martinez-Lage M, Sleiman PM, Hu W, Greene R, Wood EM, et al. Genetic and clinical features of progranulin-associated frontotemporal lobar degeneration. Arch Neurol. 2011;68(4):488-497.

141. Van Deerlin VM, Wood EM, Moore P, Yuan W, Forman MS, Clark CM, et al. Clinical, genetic, and pathologic characteristics of patients with frontotemporal dementia and progranulin mutations. Arch Neurol. 2007;64(8):1148-1153.

142. Brouwers N, Nuytemans K, van der Zee J, Gijselinck I, Engelborghs S, Theuns $\mathrm{J}$, et al. Alzheimer and Parkinson diagnoses in progranulin null mutation carriers in an extended founder family. Arch Neurol. 2007;64(10):1436-1446.

143. Tremolizzo L, Bertola F, Casati G, Piperno A, Ferrarese C, Appollonio I. Progressive supranuclear palsy-like phenotype caused by progranulin p.Thr272fs mutation. Mov Disord. 2011;26(10):1964-1966.

144. Caroppo P, Belin C, Grabli D, Maillet D, De Septenville A, Migliaccio R, et al. Posterior Cortical Atrophy as an Extreme Phenotype of GRN Mutations. JAMA Neurol. 2015;72(2):224-228.

145. Smith KR, Damiano J, Franceschetti S, Carpenter S, Canafoglia L, Morbin M, et al. Strikingly different clinicopathological phenotypes determined by progranulin-mutation dosage. Am J Hum Genet. 2012;90(6):1102-1107.

146. Gotzl JK, Mori K, Damme M, Fellerer K, Tahirovic S, Kleinberger G, et al. Common pathobiochemical hallmarks of progranulin-associated frontotemporal lobar degeneration and neuronal ceroid lipofuscinosis. Acta Neuropathol. 2014;127(6):845-860. 
147. Whitwell JL, Xu J, Mandrekar J, Boeve BF, Knopman DS, Parisi JE, et al. Frontal asymmetry in behavioral variant frontotemporal dementia: clinicoimaging and pathogenetic correlates. Neurobiol Aging. 2013;34(2):636639.

148. Le Ber I, Camuzat A, Hannequin D, Pasquier F, Guedj E, Rovelet-Lecrux A, et al. Phenotype variability in progranulin mutation carriers: a clinical, neuropsychological, imaging and genetic study. Brain. 2008;131(Pt 3):732-746.

149. Kelley BJ, Haidar W, Boeve BF, Baker M, Graff-Radford NR, Krefft T, et al. Prominent phenotypic variability associated with mutations in Progranulin. Neurobiol Aging. 2009;30(5):739-751.

150. Caroppo P, Le Ber I, Camuzat A, Clot F, Naccache L, Lamari F, et al. Extensive white matter involvement in patients with frontotemporal lobar degeneration: think progranulin. JAMA Neurol. 2014;71(12):1562-1566.

151. Mackenzie IR, Baker M, Pickering-Brown S, Hsiung GY, Lindholm C, Dwosh E, et al. The neuropathology of frontotemporal lobar degeneration caused by mutations in the progranulin gene. Brain. 2006;129(Pt 11):3081-3090.

152. Finch N, Baker M, Crook R, Swanson K, Kuntz K, Surtees R, et al. Plasma progranulin levels predict progranulin mutation status in frontotemporal dementia patients and asymptomatic family members. Brain. 2009;132(Pt 3):583-591.

153. Ghidoni R, Benussi L, Glionna M, Franzoni M, Binetti G. Low plasma progranulin levels predict progranulin mutations in frontotemporal lobar degeneration. Neurology. 2008;71(16):1235-1239.

154. Ghidoni R, Stoppani E, Rossi G, Piccoli E, Albertini V, Paterlini A, et al. Optimal plasma progranulin cutoff value for predicting null progranulin mutations in neurodegenerative diseases: a multicenter Italian study. Neurodegener Dis. 2012;9(3):121-127.

155. Sleegers K, Brouwers N, Van Damme P, Engelborghs S, Gijselinck I, van der Zee J, et al. Serum biomarker for progranulin-associated frontotemporal lobar degeneration. Ann Neurol. 2009;65(5):603-609.

156. Kumar-Singh S. Progranulin and TDP-43: mechanistic links and future directions. J Mol Neurosci. 2011;45(3):561-573. 
157. Rademakers R, Eriksen JL, Baker M, Robinson T, Ahmed Z, Lincoln SJ, et al. Common variation in the miR-659 binding-site of GRN is a major risk factor for TDP43-positive frontotemporal dementia. Hum Mol Genet. 2008;17(23):36313642.

158. Rollinson S, Rohrer JD, van der Zee J, Sleegers K, Mead S, Engelborghs S, et al. No association of PGRN 3'UTR rs5848 in frontotemporal lobar degeneration. Neurobiol Aging. 2011;32(4):754-755.

159. Simon-Sanchez J, Seelaar H, Bochdanovits Z, Deeg DJ, van Swieten JC, Heutink P. Variation at GRN 3'-UTR rs5848 is not associated with a risk of frontotemporal lobar degeneration in Dutch population. PLOS One. 2009;4(10):e7494.

160. Chen Y, Li S, Su L, Sheng J, Lv W, Chen G, et al. Association of progranulin polymorphism rs5848 with neurodegenerative diseases: a meta-analysis. $J$ Neurol. 2015. [Epub ahead of print]

161. Farg MA, Sundaramoorthy V, Sultana JM, Yang S, Atkinson RA, Levina V, et al. C9ORF72, implicated in amytrophic lateral sclerosis and frontotemporal dementia, regulates endosomal trafficking. Hum Mol Genet. 2014;23(13):35793595 .

162. Ash PE, Bieniek KF, Gendron TF, Caulfield T, Lin WL, Dejesus-Hernandez M, et al. Unconventional translation of C9ORF72 GGGGCC expansion generates insoluble polypeptides specific to c9FTD/ALS. Neuron. 2013;77(4):639-646.

163. Mori K, Weng SM, Arzberger T, May S, Rentzsch K, Kremmer E, et al. The C9orf72 GGGGCC repeat is translated into aggregating dipeptide-repeat proteins in FTLD/ALS. Science. 2013;339(6125):1335-1338.

164. Cruts M, Gijselinck I, Van Langenhove T, van der Zee J, Van Broeckhoven C. Current insights into the C9orf72 repeat expansion diseases of the FTLD/ALS spectrum. Trends Neurosci. 2013;36(8):450-459.

165. Donnelly CJ, Zhang PW, Pham JT, Heusler AR, Mistry NA, Vidensky S, et al. RNA toxicity from the ALS/FTD C9ORF72 expansion is mitigated by antisense intervention. Neuron. 2013;80(2):415-428.

166. Lee YB, Chen HJ, Peres JN, Gomez-Deza J, Attig J, Stalekar M, et al. Hexanucleotide repeats in ALS/FTD form length-dependent RNA foci, sequester RNA binding proteins, and are neurotoxic. Cell Rep. 2013;5(5):11781186. 
167. Cooper-Knock J, Walsh MJ, Higginbottom A, Robin Highley J, Dickman MJ, Edbauer D, et al. Sequestration of multiple RNA recognition motif-containing proteins by C9orf72 repeat expansions. Brain. 2014;137(Pt 7):2040-2051.

168. Mizielinska S, Isaacs AM. C9orf72 amyotrophic lateral sclerosis and frontotemporal dementia: gain or loss of function? Curr Opin Neurol. 2014;27(5):515-523.

169. Donnelly CJ, Zhang PW, Pham JT, Haeusler AR, Mistry NA, Vidensky S, et al. RNA toxicity from the ALS/FTD C9ORF72 expansion is mitigated by antisense intervention. Neuron. 2013;80(2):415-428.

170. Kwon I, Xiang S, Kato M, Wu L, Theodoropoulos P, Wang T, et al. Polydipeptides encoded by the C9orf72 repeats bind nucleoli, impede RNA biogenesis, and kill cells. Science. 2014;345(6201):1139-1145.

171. Mizielinska S, Gronke S, Niccoli T, Ridler CE, Clayton EL, Devoy A, et al. C9orf72 repeat expansions cause neurodegeneration in Drosophila through arginine-rich proteins. Science. 2014;345(6201):1192-1194.

172. Wen X, Tan W, Westergard T, Krishnamurthy K, Markandaiah SS, Shi Y, et al. Antisense Proline-Arginine RAN Dipeptides Linked to C9ORF72-ALS/FTD Form Toxic Nuclear Aggregates that Initiate In Vitro and In Vivo Neuronal Death. Neuron. 2014;84(6):1213-1225.

173. Xi Z, Zinman L, Moreno D, Schymick J, Liang Y, Sato C, et al. Hypermethylation of the $\mathrm{CpG}$ island near the G4C2 repeat in ALS with a C9orf72 expansion. Am J Hum Genet. 2013;92(6):981-989.

174. Liu EY, Russ J, Wu K, Neal D, Suh E, McNally AG, et al. C9orf72 hypermethylation protects against repeat expansion-associated pathology in ALS/FTD. Acta Neuropathol. 2014;128(4):525-541.

175. Russ J, Liu EY, Wu K, Neal D, Suh E, Irwin DJ, et al. Hypermethylation of repeat expanded C9orf72 is a clinical and molecular disease modifier. Acta Neuropathol. 2015;129(1):39-52.

176. Cooper-Knock J, Higginbottom A, Connor-Robson N, Bayatti N, Bury JJ, Kirby $\mathrm{J}$, et al. C9ORF72 transcription in a frontotemporal dementia case with two expanded alleles. Neurology. 2013;81(19):1719-1721. 
177. Fratta P, Poulter M, Lashley T, Rohrer JD, Polke JM, Beck J, et al. Homozygosity for the C9orf72 GGGGCC repeat expansion in frontotemporal dementia. Acta Neuropathol. 2013;126(3):401-409.

178. Majounie E, Renton AE, Mok K, Dopper EG, Waite A, Rollinson S, et al. Frequency of the C9orf72 hexanucleotide repeat expansion in patients with amyotrophic lateral sclerosis and frontotemporal dementia: a cross-sectional study. Lancet Neurol. 2012;11(4):323-330.

179. Beck J, Poulter M, Hensman D, Rohrer JD, Mahoney CJ, Adamson G, et al. Large C9orf72 hexanucleotide repeat expansions are seen in multiple neurodegenerative syndromes and are more frequent than expected in the UK population. Am J Hum Genet. 2013;92(3):345-353.

180. Byrne S, Heverin M, Elamin M, Walsh C, Hardiman O. Intermediate repeat expansion length in C9orf72 may be pathological in amyotrophic lateral sclerosis. Amyotroph Lateral Scler Frontotemporal Degener. 2014;15(1-2):148150.

181. Gomez-Tortosa E, Gallego J, Guerrero-Lopez R, Marcos A, Gil-Neciga E, Sainz $\mathrm{MJ}$, et al. C9ORF72 hexanucleotide expansions of 20-22 repeats are associated with frontotemporal deterioration. Neurology. 2013;80(4):366-370.

182. Nuytemans K, Bademci G, Kohli MM, Beecham GW, Wang L, Young JI, et al. C9ORF72 intermediate repeat copies are a significant risk factor for Parkinson disease. Ann Hum Genet. 2013;77(5):351-363.

183. van Blitterswijk M, DeJesus-Hernandez M, Niemantsverdriet E, Murray ME, Heckman MG, Diehl NN, et al. Association between repeat sizes and clinical and pathological characteristics in carriers of C9ORF72 repeat expansions (Xpansize-72): a cross-sectional cohort study. Lancet Neurol. 2013;12(10):978988.

184. van Blitterswijk M, Mullen B, Wojtas A, Heckman MG, DiehI NN, Baker MC, et al. Genetic modifiers in carriers of repeat expansions in the C9ORF72 gene. Mol Neurodegener. 2014;9:38.

185. van Blitterswijk M, Mullen B, Nicholson AM, Bieniek KF, Heckman MG, Baker MC, et al. TMEM106B protects C9ORF72 expansion carriers against frontotemporal dementia. Acta Neuropathol. 2014;127(3):397-406. 
186. van Blitterswijk M, Mullen B, Heckman MG, Baker MC, DeJesus-Hernandez M, Brown $\mathrm{PH}$, et al. Ataxin-2 as potential disease modifier in C9ORF72 expansion carriers. Neurobiol Aging. 2014;35(10):2421 e2413-2427.

187. Galimberti D, Arosio B, Fenoglio C, Serpente M, Cioffi SM, Bonsi R, et al. Incomplete penetrance of the C9ORF72 hexanucleotide repeat expansions: frequency in a cohort of geriatric non-demented subjects. J Alzheimers Dis. 2014;39(1):19-22.

188. Dols-Icardo O, Garcia-Redondo A, Rojas-Garcia R, Sanchez-Valle R, Noguera A, Gomez-Tortosa E, et al. Characterization of the repeat expansion size in C9orf72 in amyotrophic lateral sclerosis and frontotemporal dementia. Hum Mol Genet. 2014;23(3):749-754.

189. Chio A, Borghero G, Restagno G, Mora G, Drepper C, Traynor BJ, et al. Clinical characteristics of patients with familial amyotrophic lateral sclerosis carrying the pathogenic GGGGCC hexanucleotide repeat expansion of C9ORF72. Brain. 2012;135(Pt 3):784-793.

190. Hsiung GY, DeJesus-Hernandez M, Feldman HH, Sengdy P, Bouchard-Kerr P, Dwosh E, et al. Clinical and pathological features of familial frontotemporal dementia caused by C9ORF72 mutation on chromosome 9p. Brain. 2012;135(Pt 3):709-722.

191. van der Zee J, Gijselinck I, Dillen L, Van Langenhove T, Theuns J, Engelborghs $\mathrm{S}$, et al. A pan-European study of the C9orf72 repeat associated with FTLD: geographic prevalence, genomic instability, and intermediate repeats. Hum Mutat. 2013;34(2):363-373.

192. Ogaki K, Li Y, Takanashi M, Ishikawa K, Kobayashi T, Nonaka T, et al. Analyses of the MAPT, PGRN, and C9orf72 mutations in Japanese patients with FTLD, PSP, and CBS. Parkinsonism Relat Disord. 2013;19(1):15-20.

193. Kim EJ, Kwon JC, Park KH, Park KW, Lee JH, Choi SH, et al. Clinical and genetic analysis of MAPT, GRN, and C9orf72 genes in Korean patients with frontotemporal dementia. Neurobiol Aging. 2014;35(5):1213 e1213-1217.

194. Sha SJ, Takada LT, Rankin KP, Yokoyama JS, Rutherford NJ, Fong JC, et al. Frontotemporal dementia due to C9ORF72 mutations: clinical and imaging features. Neurology. 2012;79(10):1002-1011. 
195. Simon-Sanchez J, Dopper EG, Cohn-Hokke PE, Hukema RK, Nicolaou N, Seelaar $\mathrm{H}$, et al. The clinical and pathological phenotype of C9ORF72 hexanucleotide repeat expansions. Brain. 2012;135(Pt 3):723-735.

196. Snowden JS, Rollinson S, Thompson JC, Harris JM, Stopford CL, Richardson $\mathrm{AM}$, et al. Distinct clinical and pathological characteristics of frontotemporal dementia associated with C9ORF72 mutations. Brain. 2012;135(Pt 3):693-708.

197. Galimberti D, Fenoglio C, Serpente M, Villa C, Bonsi R, Arighi A, et al. Autosomal dominant frontotemporal lobar degeneration due to the C9ORF72 hexanucleotide repeat expansion: late-onset psychotic clinical presentation. Biol Psychiatry. 2013;74(5):384-391.

198. Dobson-Stone C, Hallupp M, Loy CT, Thompson EM, Haan E, Sue CM, et al. C9ORF72 repeat expansion in Australian and Spanish frontotemporal dementia patients. PLoS One. 2013;8(2):e56899.

199. Takada LT, Sha SJ. Neuropsychiatric features of C9orf72-associated behavioral variant frontotemporal dementia and frontotemporal dementia with motor neuron disease. Alzheimers Res Ther. 2012;4(5):38.

200. Boeve BF, Graff-Radford NR. Cognitive and behavioral features of c9FTD/ALS. Alzheimers Res Ther. 2012;4(4):29.

201. Smith BN, Newhouse S, Shatunov A, Vance C, Topp S, Johnson L, et al. The C9ORF72 expansion mutation is a common cause of ALS+/-FTD in Europe and has a single founder. Eur J Hum Genet. 2013;21(1):102-108.

202. van Rheenen W, van Blitterswijk M, Huisman MH, Vlam L, van Doormaal PT, Seelen M, et al. Hexanucleotide repeat expansions in C9ORF72 in the spectrum of motor neuron diseases. Neurology. 2012;79(9):878-882.

203. Cooper-Knock J, Hewitt C, Highley JR, Brockington A, Milano A, Man S, et al. Clinico-pathological features in amyotrophic lateral sclerosis with expansions in C9ORF72. Brain. 2012;135(Pt 3):751-764.

204. Xi Z, Zinman L, Grinberg Y, Moreno D, Sato C, Bilbao JM, et al. Investigation of c9orf72 in 4 neurodegenerative disorders. Arch Neurol. 2012;69(12):15831590 .

205. Cacace R, Van Cauwenberghe C, Bettens K, Gijselinck I, van der Zee J, Engelborghs S, et al. C9orf72 G4C2 repeat expansions in Alzheimer's disease and mild cognitive impairment. Neurobiol Aging. 2013;34(6):1712 e1711-1717. 
206. Davidson YS, Robinson AC, Snowden JS, Mann DM. Pathological assessments for the presence of hexanucleotide repeat expansions in C9ORF72 in Alzheimer's disease. Acta Neuropathol Commun. 2013;1(1):50.

207. Harms M, Benitez BA, Cairns N, Cooper B, Cooper P, Mayo K, et al. C9orf72 hexanucleotide repeat expansions in clinical Alzheimer disease. JAMA Neurol. 2013;70(6):736-741.

208. Kohli MA, John-Williams K, Rajbhandary R, Naj A, Whitehead P, Hamilton K, et al. Repeat expansions in the C9ORF72 gene contribute to Alzheimer's disease in Caucasians. Neurobiol Aging. 2013;34(5):1519 e1515-1512.

209. Majounie E, Abramzon Y, Renton AE, Keller MF, Traynor BJ, Singleton AB. Large C9orf72 repeat expansions are not a common cause of Parkinson's disease. Neurobiol Aging. 2012;33(10):2527 e2521-2522.

210. Cooper-Knock J, Frolov A, Highley JR, Charlesworth G, Kirby J, Milano A, et al. C9ORF72 expansions, parkinsonism, and Parkinson disease: a clinicopathologic study. Neurology. 2013;81(9):808-811.

211. Dejesus-Hernandez M, Rayaprolu S, Soto-Ortolaza Al, Rutherford NJ, Heckman MG, Traynor S, et al. Analysis of the C9orf72 repeat in Parkinson's disease, essential tremor and restless legs syndrome. Parkinsonism Relat Disord. 2013;19(2):198-201.

212. Lesage S, Le Ber I, Condroyer C, Broussolle E, Gabelle A, Thobois S, et al. C9orf72 repeat expansions are a rare genetic cause of parkinsonism. Brain. 2013;136(Pt 2):385-391.

213. Ticozzi N, Tiloca C, Calini D, Gagliardi S, Altieri A, Colombrita C, et al. C9orf72 repeat expansions are restricted to the ALS-FTD spectrum. Neurobiol Aging. 2014;35(4):936 e913-937.

214. Lindquist SG, Duno M, Batbayli M, Puschmann A, Braendgaard H, Mardosiene $\mathrm{S}$, et al. Corticobasal and ataxia syndromes widen the spectrum of C9ORF72 hexanucleotide expansion disease. Clin Genet. 2013;83(3):279-283.

215. Murray ME, DeJesus-Hernandez M, Rutherford NJ, Baker M, Duara R, GraffRadford NR, et al. Clinical and neuropathologic heterogeneity of c9FTD/ALS associated with hexanucleotide repeat expansion in C9ORF72. Acta Neuropathol. 2011;122(6):673-690. 
216. Fogel BL, Pribadi M, Pi S, Perlman SL, Geschwind DH, Coppola G. C9ORF72 expansion is not a significant cause of sporadic spinocerebellar ataxia. Mov Disord. 2012;27(14):1832-1833.

217. Ismail A, Cooper-Knock J, Highley JR, Milano A, Kirby J, Goodall E, et al. Concurrence of multiple sclerosis and amyotrophic lateral sclerosis in patients with hexanucleotide repeat expansions of C9ORF72. I Neurol Neurosurg Psychiatry. 2013;84(1):79-87.

218. Hensman Moss DJ, Poulter M, Beck J, Hehir J, Polke JM, Campbell T, et al. C9orf72 expansions are the most common genetic cause of Huntington disease phenocopies. Neurology. 2014;82(4):292-299.

219. Galimberti D, Reif A, Dell'osso B, Kittel-Schneider S, Leonhard C, Herr A, et al. C9ORF72 hexanucleotide repeat expansion is a rare cause of schizophrenia. Neurobiol Aging. 2014;35(5):1214 e1217-1214 e1210.

220. Galimberti D, Reif A, Dell'Osso B, Palazzo C, Villa C, Fenoglio C, et al. C9ORF72 hexanucleotide repeat expansion as a rare cause of bipolar disorder. Bipolar Disord. 2014;16(4):448-449.

221. Kandiah N, Sengdy P, Mackenzie IR, Hsiung GY, de Jesus-Hernandez M, Rademakers R. Rapidly progressive dementia in a Chinese patient due to C90RF72 mutation. Can J Neurol Sci. 2012;39(5):676-677.

222. Khan BK, Yokoyama JS, Takada LT, Sha SJ, Rutherford NJ, Fong JC, et al. Atypical, slowly progressive behavioural variant frontotemporal dementia associated with C9ORF72 hexanucleotide expansion. J Neurol Neurosurg Psychiatry. 2012;83(4):358-364.

223. Byrne S, Elamin M, Bede P, Shatunov A, Walsh C, Corr B, et al. Cognitive and clinical characteristics of patients with amyotrophic lateral sclerosis carrying a C9orf72 repeat expansion: a population-based cohort study. Lancet Neurol. 2012;11(3):232-240.

224. Irwin DJ, McMillan CT, Brettschneider J, Libon DJ, Powers J, Rascovsky K, et al. Cognitive decline and reduced survival in C9orf72 expansion frontotemporal degeneration and amyotrophic lateral sclerosis. J Neurol Neurosurg Psychiatry. 2013;84(2):163-169.

225. Mahoney CJ, Downey LE, Ridgway GR, Beck J, Clegg S, Blair M, et al. Longitudinal neuroimaging and neuropsychological profiles of frontotemporal dementia with C9ORF72 expansions. Alzheimers Res Ther. 2012;4(5):41. 
226. Lee SE, Khazenzon AM, Trujillo AJ, Guo CC, Yokoyama JS, Sha SJ, et al. Altered network connectivity in frontotemporal dementia with C9orf72 hexanucleotide repeat expansion. Brain. 2014;137(Pt 11):3047-3060.

227. Mackenzie IR, Frick $P$, Neumann $M$. The neuropathology associated with repeat expansions in the C9ORF72 gene. Acta Neuropathol. 2014;127(3):347-357.

228. Al-Sarraj S, King A, Troakes C, Smith B, Maekawa S, Bodi I, et al. p62 positive, TDP-43 negative, neuronal cytoplasmic and intranuclear inclusions in the cerebellum and hippocampus define the pathology of C9orf72-linked FTLD and MND/ALS. Acta Neuropathol. 2011;122(6):691-702.

229. Proudfoot M, Gutowski NJ, Edbauer D, Hilton DA, Stephens M, Rankin J, et al. Early dipeptide repeat pathology in a frontotemporal dementia kindred with C9ORF72 mutation and intellectual disability. Acta Neuropathol. 2014;127(3):451-458.

230. Mackenzie IR, Arzberger T, Kremmer E, Troost D, Lorenzl S, Mori K, et al. Dipeptide repeat protein pathology in C9ORF72 mutation cases: clinicopathological correlations. Acta Neuropathol. 2013;126(6):859-879.

231. Yamakawa $\mathrm{M}$, Ito $\mathrm{D}$, Honda $\mathrm{T}$, Kubo $\mathrm{KI}$, Noda $\mathrm{M}$, Nakajima $\mathrm{K}$, et al. Characterization of the dipeptide repeat protein in the molecular pathogenesis of c9FTD/ALS. Hum Mol Genet. 2014.

232. van Blitterswijk M, Baker MC, DeJesus-Hernandez M, Ghidoni R, Benussi L, Finger E, et al. C9ORF72 repeat expansions in cases with previously identified pathogenic mutations. Neurology. 2013;81(15):1332-1341.

233. van Blitterswijk M, van Es MA, Hennekam EA, Dooijes D, van Rheenen W, Medic $\mathrm{J}$, et al. Evidence for an oligogenic basis of amyotrophic lateral sclerosis. Hum Mol Genet. 2012;21(17):3776-3784.

234. Lashley T, Rohrer JD, Mahoney C, Gordon E, Beck J, Mead S, et al. A pathogenic progranulin mutation and C9orf72 repeat expansion in a family with frontotemporal dementia. Neuropathol Appl Neurobiol. 2014;40(4):502-513.

235. Gendron TF, Rademakers R, Petrucelli L. TARDBP mutation analysis in TDP43 proteinopathies and deciphering the toxicity of mutant TDP-43. J Alzheimers Dis. 2013;33 Suppl 1:S35-45. 
236. Lattante S, Rouleau GA, Kabashi E. TARDBP and FUS mutations associated with amyotrophic lateral sclerosis: summary and update. Hum Mutat. 2013;34(6):812-826 .

237. Mosca L, Lunetta C, Tarlarini C, Avemaria F, Maestri E, Melazzini M, et al. Wide phenotypic spectrum of the TARDBP gene: homozygosity of A382T mutation in a patient presenting with amyotrophic lateral sclerosis, Parkinson's disease, and frontotemporal lobar degeneration, and in neurologically healthy subject. Neurobiol Aging. 2012;33(8):1846 e1841-1844.

238. Floris G, Borghero G, Cannas A, Di Stefano F, Murru MR, Corongiu D, et al. Clinical phenotypes and radiological findings in frontotemporal dementia related to TARDBP mutations. J Neurol. 2015;262(2):375-384.

239. Benajiba L, Le Ber I, Camuzat A, Lacoste M, Thomas-Anterion C, Couratier P, et al. TARDBP mutations in motoneuron disease with frontotemporal lobar degeneration. Ann Neurol. 2009;65(4):470-473.

240. Borroni B, Bonvicini C, Alberici A, Buratti E, Agosti C, Archetti S, et al. Mutation within TARDBP leads to frontotemporal dementia without motor neuron disease. Hum Mutat. 2009;30(11):E974-983.

241. Huey ED, Ferrari R, Moreno JH, Jensen C, Morris CM, Potocnik F, et al. FUS and TDP43 genetic variability in FTD and CBS. Neurobiol Aging. 2012;33(5):1016 e1019-1017.

242. Gelpi E, van der Zee J, Estrada AT, van Broeckhoven C, Sanchez-Valle R. TARDBP mutation p.lle383Val associated with semantic dementia and complex proteinopathy. Neuropathol Appl Neurobiol. 2014;40(2):225-30.

243. Synofzik M, Born C, Rominger A, Lummel N, Schols L, Biskup S, et al. Targeted high-throughput sequencing identifies a TARDBP mutation as a cause of earlyonset FTD without motor neuron disease. Neurobiol Aging. 2014; 35(5):1212.e1-5.

244. Costa, Thaís Virgínia Moura Machado. Análise da presença de mutação no gene TARDBP em pacientes com degeneração lobar frontotemporal e implementação de metodologia para determinação dos polimorfismos do gene APOE em pacientes com Doença de Alzheimer em São Paulo - SP [dissertação]. São Paulo: Universidade de São Paulo, Faculdade de Medicina; 2012 [acesso 2015-03-07]. Disponível em: http://www.teses.usp.br/teses/disponiveis/5/5138/tde-02102012-084400/. 
245. Corrado L, Ratti A, Gellera C, Buratti E, Castellotti B, Carlomagno Y, et al. High frequency of TARDBP gene mutations in Italian patients with amyotrophic lateral sclerosis. Hum Mutat. 2009;30(4):688-694.

246. Fujita $Y$, Ikeda $M$, Yanagisawa $T$, Senoo $Y$, Okamoto K. Different clinical and neuropathologic phenotypes of familial ALS with A315E TARDBP mutation. Neurology. 2011;77(15):1427-1431.

247. Cannas A, Borghero G, Floris GL, Solla P, Chio A, Traynor BJ, et al. The p.A382T TARDBP gene mutation in Sardinian patients affected by Parkinson's disease and other degenerative parkinsonisms. Neurogenetics. 2013;14(2):161-166.

248. Rayaprolu S, Fujioka S, Traynor S, Soto-Ortolaza AI, Petrucelli L, Dickson DW, et al. TARDBP mutations in Parkinson's disease. Parkinsonism Relat Disord. 2013;19(3):312-315.

249. Kovacs GG, Murrell JR, Horvath S, Haraszti L, Majtenyi K, Molnar MJ, et al. TARDBP variation associated with frontotemporal dementia, supranuclear gaze palsy, and chorea. Mov Disord. 2009;24(12):1843-1847.

250. Praline J, Vourc'h P, Guennoc AM, Veyrat-Durebex C, Corcia P. Co-occurrence of progressive anarthria with an S393L TARDBP mutation and ALS within a family. Amyotroph Lateral Scler. 2012;13(1):155-157.

251. Homma T, Nagaoka U, Kawata A, Mochizuki Y, Kawakami H, Maruyama H, et al. Neuropathological features of Japanese familial amyotrophic lateral sclerosis with p.N352S mutation in TARDBP. Neuropathol Appl Neurobiol. 2014;40(2):231-236.

252. Mackenzie IR, Neumann M. FET proteins in frontotemporal dementia and amyotrophic lateral sclerosis. Brain Res. 2012;1462:40-43.

253. Deng $\mathrm{H}, \mathrm{Gao} \mathrm{K}$, Jankovic J. The role of FUS gene variants in neurodegenerative diseases. Nat Rev Neurol. 2014;10(6):337-348.

254. Vance C, Rogelj B, Hortobagyi T, De Vos KJ, Nishimura AL, Sreedharan J, et al. Mutations in FUS, an RNA processing protein, cause familial amyotrophic lateral sclerosis type 6. Science. 2009;323(5918):1208-1211.

255. Ticozzi N, Silani V, LeClerc AL, Keagle P, Gellera C, Ratti A, et al. Analysis of FUS gene mutation in familial amyotrophic lateral sclerosis within an Italian cohort. Neurology. 2009;73(15):1180-1185. 
256. Broustal O, Camuzat A, Guillot-Noel L, Guy N, Millecamps S, Deffond D, et al. FUS mutations in frontotemporal lobar degeneration with amyotrophic lateral sclerosis. J Alzheimers Dis. 2010;22(3):765-769.

257. Yan J, Deng HX, Siddique N, Fecto F, Chen W, Yang Y, et al. Frameshift and novel mutations in FUS in familial amyotrophic lateral sclerosis and ALS/dementia. Neurology. 2010;75(9):807-814 .

258. Van Langenhove T, van der Zee J, Sleegers K, Engelborghs S, Vandenberghe R, Gijselinck I, et al. Genetic contribution of FUS to frontotemporal lobar degeneration. Neurology. 2010;74(5):366-371.

259. Merner ND, Girard SL, Catoire H, Bourassa CV, Belzil VV, Riviere JB, et al. Exome sequencing identifies FUS mutations as a cause of essential tremor. Am J Hum Genet. 2012;91(2):313-319.

260. Rajput A, Rajput AH, Rajput ML, Encarnacion M, Bernales CQ, Ross JP, et al. Identification of FUS p.R377W in essential tremor. Eur $J$ Neurol. 2014;21(2):361-363.

261. Parmalee N, Mirzozoda K, Kisselev S, Merner N, Dion P, Rouleau G, et al. Genetic analysis of the FUS/TLS gene in essential tremor. Eur $J$ Neurol. 2013;20(3):534-539.

262. Deng HX, Chen W, Hong ST, Boycott KM, Gorrie GH, Siddique N, et al. Mutations in UBQLN2 cause dominant X-linked juvenile and adult-onset ALS and ALS/dementia. Nature. 2011;477(7363):211-215.

263. Synofzik M, Maetzler W, Grehl T, Prudlo J, Vom Hagen JM, Haack T, et al. Screening in ALS and FTD patients reveals 3 novel UBQLN2 mutations outside the PXX domain and a pure FTD phenotype. Neurobiol Aging. 2012;33(12):2949 e2913-2947.

264. Dillen L, Van Langenhove T, Engelborghs S, Vandenbulcke M, Sarafov S, Tournev I, et al. Explorative genetic study of UBQLN2 and PFN1 in an extended Flanders-Belgian cohort of frontotemporal lobar degeneration patients. Neurobiol Aging. 2013;34(6):1711 e1711-1715.

265. Gellera C, Tiloca C, Del Bo R, Corrado L, Pensato V, Agostini J, et al. Ubiquilin 2 mutations in Italian patients with amyotrophic lateral sclerosis and frontotemporal dementia. J Neurol Neurosurg Psychiatry. 2013;84(2):183-187. 
266. Lattante S, Le Ber I, Camuzat A, Pariente J, Brice A, Kabashi E, et al. Screening UBQLN-2 in French frontotemporal lobar degeneration and frontotemporal lobar degeneration-amyotrophic lateral sclerosis patients. Neurobiol Aging. 2013;34(8):2078 e2075-2076.

267. Fahed AC, McDonough B, Gouvion CM, Newell KL, Dure LS, Bebin M, et al. UBQLN2 mutation causing heterogeneous X-linked dominant neurodegeneration. Ann Neurol. 2014;75(5):793-798.

268. Williams KL, Warraich ST, Yang S, Solski JA, Fernando R, Rouleau GA, et al. UBQLN2/ubiquilin 2 mutation and pathology in familial amyotrophic lateral sclerosis. Neurobiol Aging. 2012;33(10):2527 e2523-2510.

269. Maruyama $\mathrm{H}$, Morino $\mathrm{H}$, Ito $\mathrm{H}$, Izumi $\mathrm{Y}$, Kato $\mathrm{H}$, Watanabe $\mathrm{Y}$, et al. Mutations of optineurin in amyotrophic lateral sclerosis. Nature. 2010;465(7295):223-226.

270. Ito $\mathrm{H}$, Nakamura $\mathrm{M}$, Komure $\mathrm{O}$, Ayaki $\mathrm{T}$, Wate $\mathrm{R}$, Maruyama $\mathrm{H}$, et al. Clinicopathologic study on an ALS family with a heterozygous E478G optineurin mutation. Acta Neuropathol. 2011;122(2):223-229.

271. Kamada M, Izumi Y, Ayaki T, Nakamura M, Kagawa S, Kudo E, et al. Clinicopathologic features of autosomal recessive amyotrophic lateral sclerosis associated with optineurin mutation. Neuropathology. 2014; 34(1):64-70.

272. Albagha OM, Visconti MR, Alonso N, Langston AL, Cundy T, Dargie R, et al. Genome-wide association study identifies variants at CSF1, OPTN and TNFRSF11A as genetic risk factors for Paget's disease of bone. Nat Genet. 2010;42(6):520-524.

273. Chung PY, Beyens G, Boonen S, Papapoulos S, Geusens P, Karperien M, et al. The majority of the genetic risk for Paget's disease of bone is explained by genetic variants close to the CSF1, OPTN, TM7SF4, and TNFRSF11A genes. Hum Genet. 2010;128(6):615-626.

274. Battistini S, Giannini F, Greco G, Bibbo G, Ferrera L, Marini V, et al. SOD1 mutations in amyotrophic lateral sclerosis. Results from a multicenter Italian study. J Neurol. 2005;252(7):782-788.

275. Munch C, Rosenbohm A, Sperfeld AD, Uttner I, Reske S, Krause BJ, et al. Heterozygous R1101K mutation of the DCTN1 gene in a family with ALS and FTD. Ann Neurol. 2005;58(5):777-780. 
276. van Es MA, Diekstra FP, Veldink JH, Baas F, Bourque PR, Schelhaas HJ, et al. A case of ALS-FTD in a large FALS pedigree with a K17I ANG mutation. Neurology. 2009;72(3):287-288.

277. Luty AA, Kwok JB, Dobson-Stone C, Loy CT, Coupland KG, Karlstrom H, et al. Sigma nonopioid intracellular receptor 1 mutations cause frontotemporal lobar degeneration-motor neuron disease. Ann Neurol. 2010;68(5):639-649.

278. Annesi G, Savettieri G, Pugliese P, D'Amelio M, Tarantino P, Ragonese $P$, et al. DJ-1 mutations and parkinsonism-dementia-amyotrophic lateral sclerosis complex. Ann Neurol. 2005;58(5):803-807.

279. Wicks P, Abrahams S, Papps B, Al-Chalabi A, Shaw CE, Leigh PN, et al. SOD1 and cognitive dysfunction in familial amyotrophic lateral sclerosis. J Neurol. 2009;256(2):234-241.

280. Farrer MJ, Hulihan MM, Kachergus JM, Dachsel JC, Stoessl AJ, Grantier LL, et al. DCTN1 mutations in Perry syndrome. Nat Genet. 2009;41(2):163-165.

281. Watts GD, Wymer J, Kovach MJ, Mehta SG, Mumm S, Darvish D, et al. Inclusion body myopathy associated with Paget disease of bone and frontotemporal dementia is caused by mutant valosin-containing protein. Nat Genet. 2004;36(4):377-381.

282. Johnson JO, Mandrioli J, Benatar M, Abramzon Y, Van Deerlin VM, Trojanowski $\mathrm{JQ}$, et al. Exome sequencing reveals VCP mutations as a cause of familial ALS. Neuron. 2010;68(5):857-864.

283. Mehta SG, Khare M, Ramani R, Watts GD, Simon M, Osann KE, et al. Genotype-phenotype studies of VCP-associated inclusion body myopathy with Paget disease of bone and/or frontotemporal dementia. Clin Genet. 2013;83(5):422-431.

284. Weihl CC. Valosin containing protein associated fronto-temporal lobar degeneration: clinical presentation, pathologic features and pathogenesis. Curr Alzheimer Res. 2011;8(3):252-260.

285. Bolland MJ, Cundy T. Paget's disease of bone: clinical review and update. $J$ Clin Pathol. 2013;66(11):924-927.

286. Kim HJ, Kim NC, Wang YD, Scarborough EA, Moore J, Diaz Z, et al. Mutations in prion-like domains in hnRNPA2B1 and hnRNPA1 cause multisystem proteinopathy and ALS. Nature. 2013;495(7442):467-473. 
287. Rubino E, Rainero I, Chio A, Rogaeva E, Galimberti D, Fenoglio P, et al. SQSTM1 mutations in frontotemporal lobar degeneration and amyotrophic lateral sclerosis. Neurology. 2012;79(15):1556-1562.

288. Le Ber I, Van Bortel I, Nicolas G, Bouya-Ahmed K, Camuzat A, Wallon D, et al. hnRNPA2B1 and hnRNPA1 mutations are rare in patients with "multisystem proteinopathy" and frontotemporal lobar degeneration phenotypes. Neurobiol Aging. 2014;35(4):934.e5-6.

289. van der Zee J, Pirici D, Van Langenhove T, Engelborghs S, Vandenberghe R, Hoffmann M, et al. Clinical heterogeneity in 3 unrelated families linked to VCP p.Arg159His. Neurology. 2009;73(8):626-632.

290. Kimonis VE, Mehta SG, Fulchiero EC, Thomasova D, Pasquali M, Boycott K, et al. Clinical studies in familial VCP myopathy associated with Paget disease of bone and frontotemporal dementia. Am J Med Genet A. 2008;146A(6):745-757.

291. Kimonis VE, Fulchiero E, Vesa J, Watts G. VCP disease associated with myopathy, Paget disease of bone and frontotemporal dementia: review of a unique disorder. Biochim Biophys Acta. 2008;1782(12):744-748.

292. Gonzalez-Perez P, Cirulli ET, Drory VE, Dabby R, Nisipeanu P, Carasso RL, et al. Novel mutation in VCP gene causes atypical amyotrophic lateral sclerosis. Neurology. 2012;79(22):2201-2208.

293. Seelen M, Visser AE, Overste DJ, Kim HJ, Palud A, Wong TH, et al. No mutations in hnRNPA1 and hnRNPA2B1 in Dutch patients with amyotrophic lateral sclerosis, frontotemporal dementia, and inclusion body myopathy. Neurobiol Aging. 2014;35(8):1956 e1959-1956 e1911.

294. Le Ber I, Camuzat A, Guerreiro R, Bouya-Ahmed K, Bras J, Nicolas G, et al. SQSTM1 Mutations in French Patients With Frontotemporal Dementia or Frontotemporal Dementia With Amyotrophic Lateral Sclerosis. JAMA Neurol. 2013;70(11):1403-1410.

295. Teyssou E, Takeda T, Lebon V, Boillee S, Doukoure B, Bataillon G, et al. Mutations in SQSTM1 encoding p62 in amyotrophic lateral sclerosis: genetics and neuropathology. Acta Neuropathol. 2013;125(4):511-522.

296. van der Zee J, Van Langenhove T, Kovacs GG, Dillen L, Deschamps W, Engelborghs $\mathrm{S}$, et al. Rare mutations in SQSTM1 modify susceptibility to frontotemporal lobar degeneration. Acta Neuropathol. 2014;128(3):397-410. 
297. Fecto F, Yan J, Vemula SP, Liu E, Yang Y, Chen W, et al. SQSTM1 mutations in familial and sporadic amyotrophic lateral sclerosis. Arch Neurol. $2011 ; 68(11): 1440-1446$.

298. Miller L, Rollinson S, Callister JB, Young K, Harris J, Gerhard A, et al. p62/SQSTM1 analysis in frontotemporal lobar degeneration. Neurobiol Aging. 2014.

299. Isaacs AM, Johannsen P, Holm I, Nielsen JE, consortium FR. Frontotemporal dementia caused by CHMP2B mutations. Curr Alzheimer Res. 2011;8(3):246251.

300. Skibinski G, Parkinson NJ, Brown JM, Chakrabarti L, Lloyd SL, Hummerich H, et al. Mutations in the endosomal ESCRTIII-complex subunit CHMP2B in frontotemporal dementia. Nat Genet. 2005;37(8):806-808.

301. van der Zee J, Urwin H, Engelborghs S, Bruyland M, Vandenberghe R, Dermaut $\mathrm{B}$, et al. CHMP2B C-truncating mutations in frontotemporal lobar degeneration are associated with an aberrant endosomal phenotype in vitro. Hum Mol Genet. 2008;17(2):313-322.

302. Parkinson N, Ince PG, Smith MO, Highley R, Skibinski G, Andersen PM, et al. ALS phenotypes with mutations in CHMP2B (charged multivesicular body protein 2B). Neurology. 2006;67(6):1074-1077.

303. Cox LE, Ferraiuolo L, Goodall EF, Heath PR, Higginbottom A, Mortiboys H, et al. Mutations in CHMP2B in lower motor neuron predominant amyotrophic lateral sclerosis (ALS). PLoS One. 2010;5(3):e9872.

304. van Blitterswijk M, Vlam L, van Es MA, van der Pol WL, Hennekam EA, Dooijes $\mathrm{D}$, et al. Genetic overlap between apparently sporadic motor neuron diseases. PLoS One. 2012;7(11):e48983.

305. Holm IE, Isaacs AM, Mackenzie IR. Absence of FUS-immunoreactive pathology in frontotemporal dementia linked to chromosome 3 (FTD-3) caused by mutation in the CHMP2B gene. Acta Neuropathol. 2009;118(5):719-720.

306. Van Deerlin VM, Sleiman PM, Martinez-Lage M, Chen-Plotkin A, Wang LS, Graff-Radford NR, et al. Common variants at $7 \mathrm{p} 21$ are associated with frontotemporal lobar degeneration with TDP-43 inclusions. Nat Genet. 2010;42(3):234-239. 
307. van der Zee J, Van Langenhove T, Kleinberger G, Sleegers K, Engelborghs S, Vandenberghe $\mathrm{R}$, et al. TMEM106B is associated with frontotemporal lobar degeneration in a clinically diagnosed patient cohort. Brain. 2011;134(Pt 3):808815.

308. Chen-Plotkin AS, Unger TL, Gallagher MD, Bill E, Kwong LK, Volpicelli-Daley $\mathrm{L}$, et al. TMEM106B, the risk gene for frontotemporal dementia, is regulated by the microRNA-132/212 cluster and affects progranulin pathways. $J$ Neurosci. 2012;32(33):11213-11227.

309. Brady OA, Zheng Y, Murphy K, Huang M, Hu F. The frontotemporal lobar degeneration risk factor, TMEM106B, regulates lysosomal morphology and function. Hum Mol Genet. 2013;22(4):685-695.

310. Lang CM, Fellerer K, Schwenk BM, Kuhn PH, Kremmer E, Edbauer D, et al. Membrane orientation and subcellular localization of transmembrane protein 106B (TMEM106B), a major risk factor for frontotemporal lobar degeneration. $J$ Biol Chem. 2012;287(23):19355-19365.

311. Nicholson AM, Finch NA, Wojtas A, Baker MC, Perkerson RB, 3rd, CastanedesCasey M, et al. TMEM106B p.T185S regulates TMEM106B protein levels: implications for frontotemporal dementia. J Neurochem. 2013;126(6):781-791.

312. Finch N, Carrasquillo MM, Baker M, Rutherford NJ, Coppola G, DejesusHernandez $M$, et al. TMEM106B regulates progranulin levels and the penetrance of FTLD in GRN mutation carriers. Neurology. 2011;76(5):467-474.

313. Cruchaga C, Graff C, Chiang HH, Wang J, Hinrichs AL, Spiegel N, et al. Association of TMEM106B gene polymorphism with age at onset in granulin mutation carriers and plasma granulin protein levels. Arch Neurol. 2011;68(5):581-586.

314. Gallagher MD, Suh E, Grossman M, Elman L, McCluskey L, Van Swieten JC, et al. TMEM106B is a genetic modifier of frontotemporal lobar degeneration with C9orf72 hexanucleotide repeat expansions. Acta Neuropathol. 2014;127(3):407-418.

315. Irwin DJ, Trojanowski JQ, Grossman M. Cerebrospinal fluid biomarkers for differentiation of frontotemporal lobar degeneration from Alzheimer's disease. Front Aging Neurosci. 2013;5:6.

316. Boxer AL, Gold M, Huey E, Gao FB, Burton EA, Chow T, et al. Frontotemporal degeneration, the next therapeutic frontier: molecules and animal models for 
frontotemporal degeneration drug development. Alzheimers Dement. 2013;9(2):176-188.

317. Grossman M, Farmer J, Leight S, Work M, Moore P, Van Deerlin V, et al. Cerebrospinal fluid profile in frontotemporal dementia and Alzheimer's disease. Ann Neurol. 2005;57(5):721-729.

318. Rosso SM, van Herpen E, Pijnenburg YA, Schoonenboom NS, Scheltens P, Heutink $\mathrm{P}$, et al. Total tau and phosphorylated tau 181 levels in the cerebrospinal fluid of patients with frontotemporal dementia due to P301L and G272V tau mutations. Arch Neurol. 2003;60(9):1209-1213.

319. Riemenschneider M, Wagenpfeil S, Diehl J, Lautenschlager N, Theml T, Heldmann B, et al. Tau and Abeta42 protein in CSF of patients with frontotemporal degeneration. Neurology. 2002;58(11):1622-1628.

320. Hu WT, Watts K, Grossman M, Glass J, Lah JJ, Hales C, et al. Reduced CSF p-Tau181 to Tau ratio is a biomarker for FTLD-TDP. Neurology. 2013;81(22):1945-1952.

321. Borroni B, Benussi A, Archetti S, Galimberti D, Parnetti L, Nacmias B, et al. Csf p-tau/tau ratio as biomarker for TDP pathology in frontotemporal dementia. Amyotroph Lateral Scler Frontotemporal Degener. 2014:1-6.

322. Steinacker $P$, Hendrich $C$, Sperfeld $A D$, Jesse $S$, von Arnim CA, Lehnert $S$, et al. TDP-43 in cerebrospinal fluid of patients with frontotemporal lobar degeneration and amyotrophic lateral sclerosis. Arch Neurol. 2008;65(11):1481-1487.

323. Foulds P, McAuley E, Gibbons L, Davidson Y, Pickering-Brown SM, Neary D, et al. TDP-43 protein in plasma may index TDP-43 brain pathology in Alzheimer's disease and frontotemporal lobar degeneration. Acta Neuropathol. 2008;116(2):141-146.

324. Foulds PG, Davidson Y, Mishra M, Hobson DJ, Humphreys KM, Taylor M, et al. Plasma phosphorylated-TDP-43 protein levels correlate with brain pathology in frontotemporal lobar degeneration. Acta Neuropathol. 2009;118(5):647-658.

325. Suarez-Calvet M, Dols-Icardo O, Llado A, Sanchez-Valle R, Hernandez I, Amer $G$, et al. Plasma phosphorylated TDP-43 levels are elevated in patients with frontotemporal dementia carrying a C9orf72 repeat expansion or a GRN mutation. J Neurol Neurosurg Psychiatry. 2014;85(6):684-691. 
326. Nicholson AM, Finch NA, Thomas CS, Wojtas A, Rutherford NJ, Mielke MM, et al. Progranulin protein levels are differently regulated in plasma and CSF. Neurology. 2014;82(21):1871-1878.

327. Qu H, Deng H, Hu Z. Plasma progranulin concentrations are increased in patients with type 2 diabetes and obesity and correlated with insulin resistance. Mediators Inflamm. 2013;2013:360190.

328. Todoric J, Handisurya A, Perkmann T, Knapp B, Wagner O, Tura A, et al. Circulating progranulin levels in women with gestational diabetes mellitus and healthy controls during and after pregnancy. Eur J Endocrinol. 2012;167(4):561567.

329. Richter J, Focke D, Ebert T, Kovacs P, Bachmann A, Lossner U, et al. Serum levels of the adipokine progranulin depend on renal function. Diabetes Care. 2013;36(2):410-414.

330. Nguyen AD, Nguyen TA, Martens LH, Mitic LL, Farese RV, Jr. Progranulin: at the interface of neurodegenerative and metabolic diseases. Trends Endocrinol Metab. 2013;24(12):597-606.

331. Tanaka A, Tsukamoto H, Mitoma H, Kiyohara C, Ueda N, Ayano M, et al. Serum progranulin levels are elevated in patients with systemic lupus erythematosus, reflecting disease activity. Arthritis Res Ther. 2012;14(6):R244.

332. Carlson AM, Maurer MJ, Goergen KM, Kalli KR, Erskine CL, Behrens MD, et al. Utility of Progranulin and Serum Leukocyte Protease Inhibitor as Diagnostic and Prognostic Biomarkers in Ovarian Cancer. Cancer Epidemiol Biomarkers Prev. 2013;22(10):1730-5.

333. Carrasquillo MM, Nicholson AM, Finch N, Gibbs JR, Baker M, Rutherford NJ, et al. Genome-wide screen identifies rs646776 near sortilin as a regulator of progranulin levels in human plasma. Am J Hum Genet. 2010;87(6):890-897.

334. Hsiung GY, Fok A, Feldman HH, Rademakers R, Mackenzie IR. rs5848 polymorphism and serum progranulin level. J Neurol Sci. 2011;300(1-2):28-32.

335. Su Z, Zhang Y, Gendron TF, Bauer PO, Chew J, Yang WY, et al. Discovery of a biomarker and lead small molecules to target $r(G G G G C C)$-associated defects in c9FTD/ALS. Neuron. 2014;83(5):1043-1050. 
336. Landqvist Waldo M, Frizell Santillo A, Passant U, Zetterberg H, Rosengren L, Nilsson $\mathrm{C}$, et al. Cerebrospinal fluid neurofilament light chain protein levels in subtypes of frontotemporal dementia. BMC Neurol. 2013;13:54.

337. Scherling CS, Hall T, Berisha F, Klepac K, Karydas A, Coppola G, et al. Cerebrospinal fluid neurofilament concentration reflects disease severity in frontotemporal degeneration. Ann Neurol. 2014;75(1):116-126.

338. de Jong D, Jansen RW, Pijnenburg YA, van Geel WJ, Borm GF, Kremer HP, et al. CSF neurofilament proteins in the differential diagnosis of dementia. J Neurol Neurosurg Psychiatry. 2007;78(9):936-938.

339. Pfeffer RI, Kurosaki TT, Harrah CH, Jr., Chance JM, Filos S. Measurement of functional activities in older adults in the community. $J$ Gerontol. 1982;37(3):323-329.

340. Folstein MF, Robins LN, Helzer JE. The Mini-Mental State Examination. Arch Gen Psychiatry. 1983;40(7):812.

341. Brucki SM, Nitrini R, Caramelli P, Bertolucci PH, Okamoto IH. [Suggestions for utilization of the mini-mental state examination in Brazil]. Arq Neuropsiquiatr. 2003;61(3B):777-781.

342. Miller SA, Dykes DD, Polesky HF. A simple salting out procedure for extracting DNA from human nucleated cells. Nucleic Acids Res. 1988;16(3):1215.

343. Nitrini R, Lefevre BH, Mathias SC, Caramelli P, Carrilho PE, Sauaia N, et al. [Neuropsychological tests of simple application for diagnosing dementia]. Arq Neuropsiquiatr. 1994;52(4):457-465.

344. Sunderland T, Hill JL, Mellow AM, Lawlor BA, Gundersheimer J, Newhouse PA, et al. Clock drawing in Alzheimer's disease. A novel measure of dementia severity. J Am Geriatr Soc. 1989;37(8):725-729.

345. Cummings JL, Mega M, Gray K, Rosenberg-Thompson S, Carusi DA, Gornbein J. The Neuropsychiatric Inventory: comprehensive assessment of psychopathology in dementia. Neurology. 1994;44(12):2308-2314.

346. West JF, Sands ES, Ross-Swain D. Bedside Evaluation Screening Test Second Edition (BEST-2). 2nd ed. Austin, TX: Pro-Ed; 1998. 
347. Mansur LL, Radanovic M, Araujo Gde C, Taquemori LY, Greco LL. [Boston Naming Test: performance of Brazilian population from Sao Paulo]. Pro Fono. 2006;18(1):13-20.

348. Howard D, Patterson K. The Pyramids and Palm Trees Test: A Test of Semantic Access from Words and Pictures. London, UK: Harcourt Assessment; 1992.

349. Dubois B, Slachevsky A, Pillon B, Beato R, Villalponda JM, Litvan I. "Applause sign" helps to discriminate PSP from FTD and PD. Neurology. 2005;64(12):2132-2133.

350. Genomes Project C, Abecasis GR, Altshuler D, Auton A, Brooks LD, Durbin RM, et al. A map of human genome variation from population-scale sequencing. Nature. 2010;467(7319):1061-1073.

351. Bernardi L, Frangipane F, Smirne N, Colao R, Puccio G, Curcio SA, et al. Epidemiology and genetics of frontotemporal dementia: a door-to-door survey in southern Italy. Neurobiol Aging. 2012;33(12):2948 e2941-2948 e2910.

352. Tremolizzo L, Gelosa G, Galbussera A, Isella V, Arosio C, Bertola F, et al. Higher than expected progranulin mutation rate in a case series of Italian FTLD patients. Alzheimer Dis Assoc Disord. 2009;23(3):301.

353. Benussi L, Ghidoni R, Binetti G. Progranulin mutations are a common cause of FTLD in Northern Italy. Alzheimer Dis Assoc Disord. 2010;24(3):308-309.

354. Benussi L, Rademakers R, Rutherford NJ, Wojtas A, Glionna M, Paterlini A, et al. Estimating the age of the most common Italian GRN mutation: walking back to Canossa times. J Alzheimers Dis. 2013;33(1):69-76.

355. Pickering-Brown S, Baker M, Bird T, Trojanowski J, Lee V, Morris $\mathrm{H}$, et al. Evidence of a founder effect in families with frontotemporal dementia that harbor the tau +16 splice mutation. Am J Med Genet B Neuropsychiatr Genet. 2004;125B(1):79-82.

356. Chiang HH, Forsell C, Lilius L, Oijerstedt L, Thordardottir S, Shanmugarajan K, et al. Novel progranulin mutations with reduced serum-progranulin levels in frontotemporal lobar degeneration. Eur J Hum Genet. 2013;21(11):1260-1265.

357. Guerreiro RJ, Santana I, Bras JM, Revesz T, Rebelo O, Ribeiro MH, et al. Novel progranulin mutation: screening for PGRN mutations in a Portuguese series of FTD/CBS cases. Mov Disord. 2008;23(9):1269-1273. 
358. Das G, Sadhukhan T, Sadhukhan D, Biswas A, Pal S, Ghosh A, et al. Genetic study on frontotemporal lobar degeneration in India. Parkinsonism Relat Disord. 2013;19(4):487-489.

359. See TM, LaMarre AK, Lee SE, Miller BL. Genetic causes of frontotemporal degeneration. J Geriatr Psychiatry Neurol. 2010;23(4):260-268.

360. Forbes SA, Beare D, Gunasekaran P, Leung K, Bindal N, Boutselakis H, et al. COSMIC: exploring the world's knowledge of somatic mutations in human cancer. Nucleic Acids Res. 2015;43(Database issue):D805-811.

361. Hu J, Ng PC. Predicting the effects of frameshifting indels. Genome Biol. 2012;13(2):R9.

362. Almeida MR, Baldeiras I, Ribeiro MH, Santiago B, Machado C, Massano J, et al. Progranulin peripheral levels as a screening tool for the identification of subjects with progranulin mutations in a Portuguese cohort. Neurodegener Dis. 2014;13(4):214-223.

363. Masellis M, Momeni P, Meschino W, Heffner R, Jr., Elder J, Sato C, et al. Novel splicing mutation in the progranulin gene causing familial corticobasal syndrome. Brain. 2006;129(Pt 11):3115-3123.

364. Mesulam MM, Rogalski EJ, Wieneke C, Hurley RS, Geula C, Bigio EH, et al. Primary progressive aphasia and the evolving neurology of the language network. Nat Rev Neurol. 2014;10(10):554-569.

365. Rohrer JD, Crutch SJ, Warrington EK, Warren JD. Progranulin-associated primary progressive aphasia: a distinct phenotype? Neuropsychologia. 2010;48(1):288-297.

366. Josephs KA, Ahmed Z, Katsuse O, Parisi JF, Boeve BF, Knopman DS, et al. Neuropathologic features of frontotemporal lobar degeneration with ubiquitinpositive inclusions with progranulin gene (PGRN) mutations. J Neuropathol Exp Neurol. 2007;66(2):142-151.

367. Hornberger M, Piguet O, Graham AJ, Nestor PJ, Hodges JR. How preserved is episodic memory in behavioral variant frontotemporal dementia? Neurology. 2010;74(6):472-479.

368. Varma AR, Laitt R, Lloyd JJ, Carson KJ, Snowden JS, Neary D, et al. Diagnostic value of high signal abnormalities on T2 weighted MRI in the differentiation of 
Alzheimer's, frontotemporal and vascular dementias. Acta Neurol Scand. 2002;105(5):355-364.

369. Paloneva J, Kestila M, Wu J, Salminen A, Bohling T, Ruotsalainen V, et al. Lossof-function mutations in TYROBP (DAP12) result in a presenile dementia with bone cysts. Nat Genet. 2000;25(3):357-361.

370. Paloneva J, Manninen T, Christman G, Hovanes K, Mandelin J, Adolfsson R, et al. Mutations in two genes encoding different subunits of a receptor signaling complex result in an identical disease phenotype. Am $J$ Hum Genet. 2002;71(3):656-662.

371. Nicholson AM, Baker MC, Finch NA, Rutherford NJ, Wider C, Graff-Radford NR, et al. CSF1R mutations link POLD and HDLS as a single disease entity. Neurology. 2013;80(11):1033-1040.

372. Rademakers R, Baker M, Nicholson AM, Rutherford NJ, Finch N, Soto-Ortolaza $A$, et al. Mutations in the colony stimulating factor 1 receptor (CSF1R) gene cause hereditary diffuse leukoencephalopathy with spheroids. Nat Genet. 2012;44(2):200-205.

373. Bianchin MM, Martin KC, de Souza AC, de Oliveira MA, Rieder CR. NasuHakola disease and primary microglial dysfunction. Nat Rev Neurol. 2010;6(9):2 p following 523.

374. Klunemann HH, Ridha BH, Magy L, Wherrett JR, Hemelsoet DM, Keen RW, et al. The genetic causes of basal ganglia calcification, dementia, and bone cysts: DAP12 and TREM2. Neurology. 2005;64(9):1502-1507.

375. Paloneva J, Autti T, Raininko R, Partanen J, Salonen O, Puranen M, et al. CNS manifestations of Nasu-Hakola disease: a frontal dementia with bone cysts. Neurology. 2001;56(11):1552-1558.

376. Guerreiro RJ, Lohmann E, Bras JM, Gibbs JR, Rohrer JD, Gurunlian N, et al. Using exome sequencing to reveal mutations in TREM2 presenting as a frontotemporal dementia-like syndrome without bone involvement. JAMA Neurol. 2013;70(1):78-84.

377. Guerreiro R, Kara E, Le Ber I, Bras J, Rohrer JD, Taipa R, et al. Genetic analysis of inherited leukodystrophies: genotype-phenotype correlations in the CSF1R gene. JAMA Neurol. 2013;70(7):875-882. 
378. Sundal C, Van Gerpen JA, Nicholson AM, Wider C, Shuster EA, Aasly J, et al. $\mathrm{MRI}$ characteristics and scoring in HDLS due to CSF1R gene mutations. Neurology. 2012;79(6):566-574.

379. Carecchio M, Fenoglio C, De Riz M, Guidi I, Comi C, Cortini F, et al. Progranulin plasma levels as potential biomarker for the identification of GRN deletion carriers. A case with atypical onset as clinical amnestic Mild Cognitive Impairment converted to Alzheimer's disease. J Neurol Sci. 2009;287(1-2):291293.

380. Rodriguez-Rodriguez E, Vazquez-Higuera JL, Sanchez-Juan P, GonzalezAramburu I, Pozueta A, Mateo I, et al. Screening for progranulin mutations by serum protein dosage in common neurodegenerative disorders. Parkinsonism Relat Disord. 2013;19(8):768-769.

381. Gibbons L, Rollinson S, Thompson JC, Robinson A, Davidson YS, Richardson A, et al. Plasma levels of progranulin and interleukin- 6 in frontotemporal lobar degeneration. Neurobiol Aging. 2015;36(3):1603.e1-4.

382. Gomez-Tortosa E, Guerrero-Lopez R, Gil-Neciga E, Franco E, del Ser T, Jimenez Escrig A, et al. Plasma progranulin levels in cortical dementia phenotypes with asymmetric perisylvian atrophy. Eur $J$ Neurol. 2013;20(9):1319-1324.

383. Bagnoli S, Piaceri I, Tedde A, Piacentini S, Nannucci S, Bracco L, et al. Progranulin genetic screening in frontotemporal lobar degeneration patients from central Italy. Cell Mol Neurobiol. 2012;32(1):13-16.

384. Piscopo P, Rivabene R, Galimberti D, Crestini A, Talarico G, Vanacore N, et al. Gender effects on plasma PGRN levels in patients with Alzheimer's disease: a preliminary study. J Alzheimers Dis. 2013;35(2):313-318.

385. Antonell A, Gil S, Sanchez-Valle R, Balasa M, Bosch B, Prat MC, et al. Serum progranulin levels in patients with frontotemporal lobar degeneration and Alzheimer's disease: detection of GRN mutations in a Spanish cohort. $J$ Alzheimers Dis. 2012;31(3):581-591.

386. Galimberti D, D'Addario C, Dell'osso B, Fenoglio C, Marcone A, Cerami C, et al. Progranulin gene (GRN) promoter methylation is increased in patients with sporadic frontotemporal lobar degeneration. Neurol Sci. 2013;34(6):899-903. 
387. D'Souza I, Schellenberg GD. Determinants of 4-repeat tau expression. Coordination between enhancing and inhibitory splicing sequences for exon 10 inclusion. J Biol Chem. 2000;275(23):17700-17709.

388. D'Souza I, Schellenberg GD. Arginine/serine-rich protein interaction domaindependent modulation of a tau exon 10 splicing enhancer: altered interactions and mechanisms for functionally antagonistic FTDP-17 mutations Delta280K AND N279K. J Biol Chem. 2006;281(5):2460-2469.

389. Dawson HN, Cantillana V, Chen L, Vitek MP. The tau N279K exon 10 splicing mutation recapitulates frontotemporal dementia and parkinsonism linked to chromosome 17 tauopathy in a mouse model. J Neurosci. 2007;27(34):91559168.

390. Wszolek ZK, Pfeiffer RF, Bhatt MH, Schelper RL, Cordes M, Snow BJ, et al. Rapidly progressive autosomal dominant parkinsonism and dementia with pallido-ponto-nigral degeneration. Ann Neurol. 1992;32(3):312-320.

391. Clark LN, Poorkaj P, Wszolek Z, Geschwind DH, Nasreddine ZS, Miller B, et al. Pathogenic implications of mutations in the tau gene in pallido-ponto-nigral degeneration and related neurodegenerative disorders linked to chromosome 17. Proc Natl Acad Sci U S A. 1998;95(22):13103-13107.

392. Tsuboi Y, Baker M, Hutton ML, Uitti RJ, Rascol O, Delisle MB, et al. Clinical and genetic studies of families with the tau N279K mutation (FTDP-17). Neurology. 2002;59(11):1791-1793.

393. Soliveri P, Rossi G, Monza D, Tagliavini F, Piacentini S, Albanese A, et al. A case of dementia parkinsonism resembling progressive supranuclear palsy due to mutation in the tau protein gene. Arch Neurol. 2003;60(10):1454-1456.

394. Tsuboi Y, Uitti RJ, Delisle MB, Ferreira JJ, Brefel-Courbon C, Rascol O, et al. Clinical features and disease haplotypes of individuals with the N279K tau gene mutation: a comparison of the pallidopontonigral degeneration kindred and a French family. Arch Neurol. 2002;59(6):943-950.

395. Ferman TJ, McRae CA, Arvanitakis Z, Tsuboi Y, Vo A, Wszolek ZK. Early and pre-symptomatic neuropsychological dysfunction in the PPND family with the N279K tau mutation. Parkinsonism Relat Disord. 2003;9(5):265-270.

396. Slowinski J, Dominik J, Uitti RJ, Ahmed Z, Dickson DD, Wszolek ZK. Frontotemporal dementia and Parkinsonism linked to chromosome 17 with the N279K tau mutation. Neuropathology. 2007;27(1):73-80. 
397. Arvanitakis Z, Witte RJ, Dickson DW, Tsuboi Y, Uitti RJ, Slowinski J, et al. Clinical-pathologic study of biomarkers in FTDP-17 (PPND family with N279K tau mutation). Parkinsonism Relat Disord. 2007;13(4):230-239.

398. de Silva R, Lashley T, Strand C, Shiarli AM, Shi J, Tian J, et al. An immunohistochemical study of cases of sporadic and inherited frontotemporal lobar degeneration using 3R- and 4R-specific tau monoclonal antibodies. Acta Neuropathol. 2006;111(4):329-340.

399. Adzhubei IA, Schmidt S, Peshkin L, Ramensky VE, Gerasimova A, Bork P, et al. A method and server for predicting damaging missense mutations. Nat Methods. 2010;7(4):248-249.

400. Binetti G, Signorini S, Squitti R, Alberici A, Benussi L, Cassetta E, et al. Atypical dementia associated with a novel presenilin-2 mutation. Ann Neurol. 2003;54(6):832-836 .

401. Mendez MF, McMurtray A. Frontotemporal dementia-like phenotypes associated with presenilin-1 mutations. Am J Alzheimers Dis Other Demen. 2006;21(4):281-286.

402. Larner AJ, Doran M. Genotype-phenotype relationships of presenilin-1 mutations in Alzheimer's disease: an update. J Alzheimers Dis. 2009;17(2):259265.

403. Riudavets MA, Bartoloni L, Troncoso JC, Pletnikova O, St George-Hyslop P, Schultz M, et al. Familial dementia with frontotemporal features associated with M146V presenilin-1 mutation. Brain Pathol. 2013;23(5):595-600.

404. Marcon G, Di Fede G, Giaccone G, Rossi G, Giovagnoli AR, Maccagnano E, et al. A novel Italian presenilin 2 gene mutation with prevalent behavioral phenotype. J Alzheimers Dis. 2009;16(3):509-511.

405. Nitrini R, Rosemberg S, Passos-Bueno MR, da Silva LS, lughetti $P$, Papadopoulos $\mathrm{M}$, et al. Familial spongiform encephalopathy associated with a novel prion protein gene mutation. Ann Neurol. 1997;42(2):138-146.

406. Kara E, Kiely AP, Proukakis C, Giffin N, Love S, Hehir J, et al. A 6.4 Mb duplication of the alpha-synuclein locus causing frontotemporal dementia and Parkinsonism: phenotype-genotype correlations. JAMA Neurol. 2014;71(9):1162-1171. 
407. Beck J, Pittman A, Adamson G, Campbell T, Kenny J, Houlden H, et al. Validation of next-generation sequencing technologies in genetic diagnosis of dementia. Neurobiol Aging. 2014;35(1):261-265.

408. Wetterstrand MS. DNA Sequencing Costs: Data from the NHGRI Genome Sequencing Program (GSP). [Acessado em 07/03/2015]. Disponível em: http://www.genome.gov/sequencingcosts.

409. Kalbe E, Onur OA, Minnerop M, Reimann J, Althaus A, Ahmadzadehfar H, et al. Early signs of VCP-related frontotemporal dementia: a neuropsychological, FDG-PET and fMRI study. J Neurol. 2011;258(3):515-518.

410. Dopper EG, Rombouts SA, Jiskoot LC, Heijer T, de Graaf JR, Koning I, et al. Structural and functional brain connectivity in presymptomatic familial frontotemporal dementia. Neurology. 2013;80(9):814-823.

411. Jacova C, Hsiung GY, Tawankanjanachot I, Dinelle K, McCormick S, Gonzalez $\mathrm{M}$, et al. Anterior brain glucose hypometabolism predates dementia in progranulin mutation carriers. Neurology. 2013;81(15):1322-1331.

412. Stokholm J, Teasdale TW, Johannsen P, Nielsen JE, Nielsen TT, Isaacs A, et al. Cognitive impairment in the preclinical stage of dementia in FTD-3 CHMP2B mutation carriers: a longitudinal prospective study. I Neurol Neurosurg Psychiatry. 2013;84(2):170-176.

413. Whitwell JL, Josephs KA, Avula R, Tosakulwong N, Weigand SD, Senjem ML, et al. Altered functional connectivity in asymptomatic MAPT subjects: a comparison to bvFTD. Neurology. 2011;77(9):866-874.

414. Rohrer JD, Nicholas JM, Cash DM, van Swieten J, Dopper E, Jiskoot L, et al. Presymptomatic cognitive and neuroanatomical changes in genetic frontotemporal dementia in the Genetic Frontotemporal dementia Initiative (GENFI) study: a cross-sectional analysis. Lancet Neurol. 2015;14(3):253-262.

415. Study to Assess the Safety, Tolerability, and Pharmacodynamic (PD) Effects of FRM-0334 in Subjects With Prodromal to Moderate Frontotemporal Dementia With Granulin Mutation. [Acessado em 08/03/2015]. Disponível em https://clinicaltrials.gov/ct2/show/NCT02149160.

416. Minami SS, Min SW, Krabbe G, Wang C, Zhou Y, Asgarov R, et al. Progranulin protects against amyloid beta deposition and toxicity in Alzheimer's disease mouse models. Nat Med. 2014;20(10):1157-1164. 
417. Avale ME, Rodriguez-Martin T, Gallo JM. Trans-splicing correction of tau isoform imbalance in a mouse model of tau mis-splicing. Hum Mol Genet. 2013;22(13):2603-2611. 


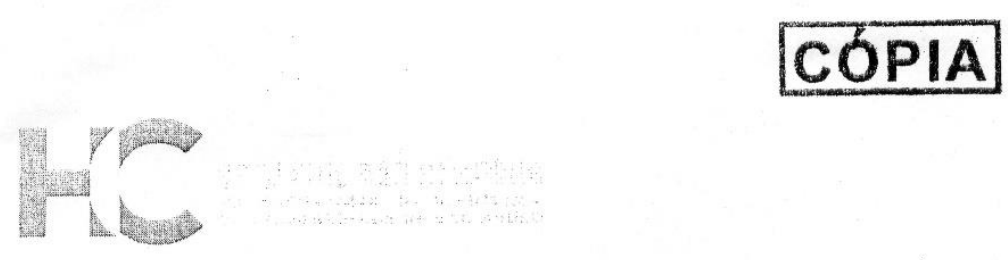

\section{APROVAÇÃO}

A Comissão de Ética para Análise de Projetos de Pesquisa CAPPesa da Diretoria Clínica do Hospital das Clínicas e da Faculdade de Medicina da Universidade de São Paulo, em sessão de 13/10/2010, AProVOU O Protocolo de Pesquisa $n^{\circ}$ 0252/10, intitulado: "ANÁlISE DA PRESENÇA E TIPO DE MUTAÇÃO DOS GENES DA PROGRANULINA E DA TDP-43 EM PACIENTES COM DEGENERAÇĀO LOBAR FRONTOTEMPORAL. E COM DOENÇA DE ALZHEIMER ALELO TIPO ESPECÍFICO" apresentado pelo Departamento de NEUROLOGIA, inclusive O Termo de Consentimento Livre e Esclarecido e o Sub projeto da mestranda Thais Virginia Moura Machado Costa.

Cabe ao pesquisador elaborar e apresentar à CAPPesq, os relatórios parciais e final sobre a pesquisa (Resolução do Conselho Nacional de Saúde $n^{\circ}$ 196, de 10/10/1996, inciso IX.2, letra "C").

Pesquisador (a) Responsável: Prof. Ricardo Nitrini e Prof. Gerson Chadi Pesquisador (a) Executante: Thaís Virgínia Moura Machado Costa e Leonel Tadao Takada

CAPPesq, 14 de Outubro de 2010

Prof. Dr. Eduardo Massad

Presidente da Comissāo de Ética para Análise de Projetos de Pesquisa

Comissão de Ética para Análise de Projetos de Pesquisa do HCFMUSP e da FMUSP Diretoria Clinica do Hospital das Clínicas da Faculdade de Medicina da Universidade de São Paulo Rua Ovídio Pires de Campos, 225, $5^{\circ}$ andar - CEP 05403010 - Săo Paulo - SP Fone: 01130696442 Fax: 01130696492 e-mail: cappesq@hcnet.usp.br/secretariacappesq2@hcnet.usp.br 
ANEXO II - Termo de Consentimento Livre e Esclarecido

HOSPITAL DAS CLÍNICAS DA FACULdADE DE MEDICINA DA UNIVERSIDADE DE SĀo PAULO-HCFMUSP

MODELO DE TERMO DE CONSENTIMENTO LIVRE E ESCLARECIDO

DADOS dE IDENTIFICAÇAO do SUJEITO dA PESQUisA OU RESPONSAVEL LEGAL

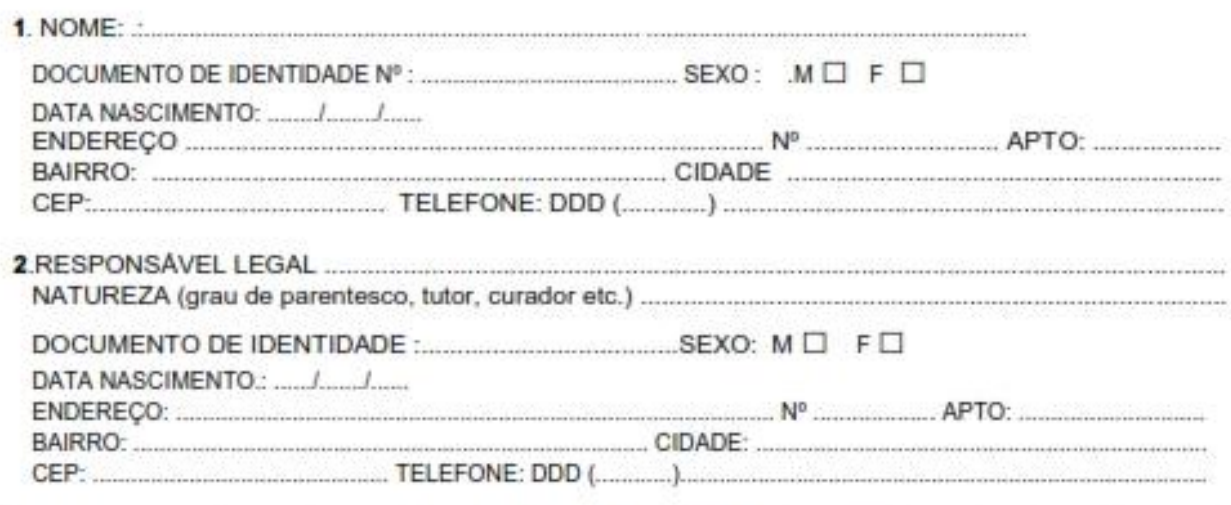

\section{DADOS SOBRE A PESQUISA}

1. TITULO DO PROTOCOLO DE PESQUISA ... Análise da presença e tipo de mutaçâo dos genes da progranulina e da TDP-43 em pacientes com Degeneraçāo Lobar Frontotemporal e com Doença de Alzheimer alelo tipo especifico.

PESQUISADORES : Professores Ricardo Nitrini e Gerson Chadi.

CARGOIFUNÇAO: Docentes. INSCRIÇAO CONSELHO REGIONAL NN 17011 (Ricardo Nitrini); 53368 (Gerson Chadi)

UNIDADE DO HCFMUSP: Departamento de Neurologia

3. AVALIAÇAO DO RISCO DA PESQUISA:

$\begin{array}{ll}\text { RISCO MINIMO } X & \text { RISCO MÉDIO } \\ \text { RISCO BAIXO } \square & \text { RISCO MAIOR }\end{array}$

4.DURAÇAO DA PESQUISA : 48 meses 


\section{HOSPITAL dAS CLÍNICAS DA FACULdAdE DE MEDICINA DA UNIVERSIDADE DE SĀo PAULO-HCFMUSP}

Nós estamos realizando uma pesquisa em que iremos verificar se existern alteraçōes genéticas chamadas mutaçōes e polimorfismos, $e$ também modificaçōes no nivel sanguineo de duas proteinas denominadas progranulina $e$ TDP-43, em pessoas que apresentam declinio da atividade intelectual ou distúrbios do comportamento. Para esse fim, iremos colher amostra de sangue $(16 \mathrm{ml})$ por meio de punção de veia superficial visivel na regiāo do braço. A coleta será realizada no Laboratório Central do IC-HCFMUSP por profissional especializado. Este exame è feito com uso de agulha descartável e apresenta desconforto ou risco minimo. As vezes poderá ser evidenciado dor e hematoma no local da punção venosa, porém de pequena intensidade e passageiros. O material será então enviado ao nosso laboratório para as análises. Você está sendo convidado por ter sido diagnosticado com Degeneraçāo Lobar Frontotemporal ou Doença de Alzheimer, ou ainda por não apresentar a doença em questāo, mas fará parte do grupo de individuos controle.

Autorizo que o material colhido e näo utilizado nesta pesquisa seja armazenado por tempo superior a 5 anos no Banco de DNA do Departamento de Neurologia para pesquisas futuras devidamente aprovadas pelo Conselho do Departamento de Neurologia e CAPPESQ da FMUSP, garantindo sempre que os dados de estudos futuros serāo confidenciais, sigilosos e privados e serāo utilizados apenas para pesquisa.

A sua participaçāo nesta pesquisa è totalmente voluntária e o seu tratamento e acompanhamento nāo serão modificados caso você nâo aceite participar desta pesquisa. Além disso, as análises efetuadas e resultados obtidos nesta pesquisa também nāo modificarão o seu tratamento e acompanhamento habitual.

Você poderá ter acesso em qualquer momento às informaçōes sobre procedimentos, riscos e beneficios relacionados à pesquisa, inclusive para esclarecer eventuais dúvidas. Você terá o direito de retirar seu consentimento em qualquer momento e de deixar de participar do estudo, sem que isto traga prejuizo à continuidade da assistência. Os dados desse estudo serāo utilizados apenas para pesquisa, de modo que a identidade dos participantes nâo será revelada. Em caso de intercorrências, você poderá entrar em contato com os Profs Drs. Ricardo Nitrini e Gerson Chadi, Professores Titulares do Depto de Neurologia. FMUSP, no LIM-45, na Av. Dr. Arnaldo, $n^{\circ} 455,2^{\circ}$ andar, sala 2119 , Cerqueira César, CEP: 01246-903; telefone: 3061-7460.

Acredito ter sido suficientemente esclarecido(a) a respeito das informaçōes que li ou que foram lidas para mim, descrevendo o estudo. Ficaram claros para mim quais sāo os propósitos do estudo, os procedimentos a serem realizados, seus desconfortos e riscos, as garantias de confidencialidade e de esclarecimentos permanentes. Ficou claro também que minha participaçāo é isenta de despesas e que tenho garantia do acesso a tratamento hospitalar quando necessário. Concordo voluntariamente em participar deste estudo e poderei retirar o meu consentimento a qualquer momento, antes ou durante o mesmo, sem penalidades ou prejuizo ou perda de qualquer beneficio que eu possa ter adquirido, ou no meu atendimento neste Serviço. 
Assinatura do paciente/representante legal* Data

Assinatura da testemunha Data

* (para casos de pessoas impossibilitadas de compreender e/ou assinar este termo).

Assinatura do individuo do grupo controle** Data 11

* (para os casos de pessoas nāo doentes e que participam do grupo controle)

\section{(Somente nara e responsável do oroiete)}

Declaro que obtive de forma apropriada e voluntária o Consentimento Livre e Esclarecido deste paciente ou representante legal para a participação neste estudo. 


\section{ANEXO III - Aprovação do Projeto FAPESP (2013/01758-4)}

\begin{tabular}{|c|c|c|}
\hline JAPESP & & 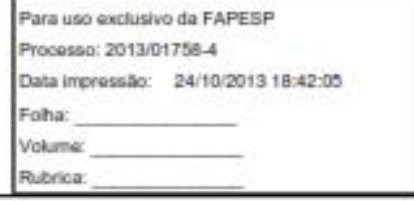 \\
\hline \multicolumn{3}{|c|}{$\begin{array}{c}\text { FUNDAÇĀO DE AMPARO Ả PESQUISA DO ESTADO DE SÃO PAULO } \\
\text { TERMO DE OUTORGA E ACEITAÇAOO DE AUXILIOS } \\
\text { PROCESSO 2013/01758-4 }\end{array}$} \\
\hline \multicolumn{3}{|c|}{$\begin{array}{l}\text { Pelo presente instrumento, a Fundação de Amparo à Pesquisa do Estado de São Paulo, com sede na Rua Pio } \\
\text { XI, n" } 1.500 \text {, Alto da Lapa, São Paulo, Capital, inscrita no CNPJ/MF sob } n^{\circ} 43.828 .151 / 0001-45 \text {, doravante } \\
\text { denominada OUTORGANTE, por meio de seu Conselho Técnico-Administrativo, nos termos do Artigo 14, letra } \\
\text { "b", da Lei Estadual } n^{\circ} 5.918 \text {, de } 18 \text { de outubro de } 1960 \text {, concede ao OUTORGADO, a seguir qualificado, } \\
\text { Auxilio para a realizaçấo do Projeto de Pesquisa a seguir especificado, nas instalaçōes e com o apoio da } \\
\text { INSTITUIÇĀo SEDE, de acordo com as especificaçōes, cláusulas e condiçōes descritas a seguir e nos Anexos, } \\
\text { que passam a ser parte integrante deste Termo. }\end{array}$} \\
\hline 1.OUTORGADO: & $\begin{array}{l}\text { Ricardo Nitrini } \\
\text { CPF: } 216.911 .508-00 \\
\text { RG: } 3563136-S S P / S P\end{array}$ & \\
\hline 2.Correspondència: & $\begin{array}{l}\text { Rua Itapeva, } 378 \text {, conj. } 9 \\
\text { mitrini@uol.com.br }\end{array}$ & Paulo/SP, CEP 01332-000 \\
\hline 3.Instituição Sede: & $\begin{array}{l}\text { Faculdade de Medicina/F } \\
\text { Universidade de Sāo Pat }\end{array}$ & \\
\hline 4.Projeto de Pesquisa: & $\begin{array}{l}\text { Pesquisa de mutaçöes d } \\
\text { progranulina em casuisti } \\
\text { frontotemporal }\end{array}$ & $\begin{array}{l}\text { Osagem plasmática de } \\
\text { ientes com degeneraçāo lobar }\end{array}$ \\
\hline 5. Linha de Fomento: & $\begin{array}{l}\text { Programas Regulares / A } \\
\text { Pesquisa - Regular }\end{array}$ & / Projeto de Pesquisa / Projeto de \\
\hline 6.Área/Subárea: & $\begin{array}{l}\text { Medicina } \\
\text { Outra Subárea Medicina }\end{array}$ & \\
\hline 7.Coordenaçāo: & Saúde I & \\
\hline 8.Periodo da Vigência: & $01 / 07 / 2013$ a $30 / 06 / 2015$ & \\
\hline 9.Relatórios Cientificos: & $30 / 06 / 2014,30 / 07 / 2015$ & \\
\hline 10.Prestaçōes de Contas: & $30 / 06 / 2014,30 / 07 / 2015$ & \\
\hline
\end{tabular}

